\title{
Meesterschap in tweevoud Novellen en schetsen van Rosalie en Virginie Loveling
}

\section{Piet Couttenier en Anne Marie Musschoot}

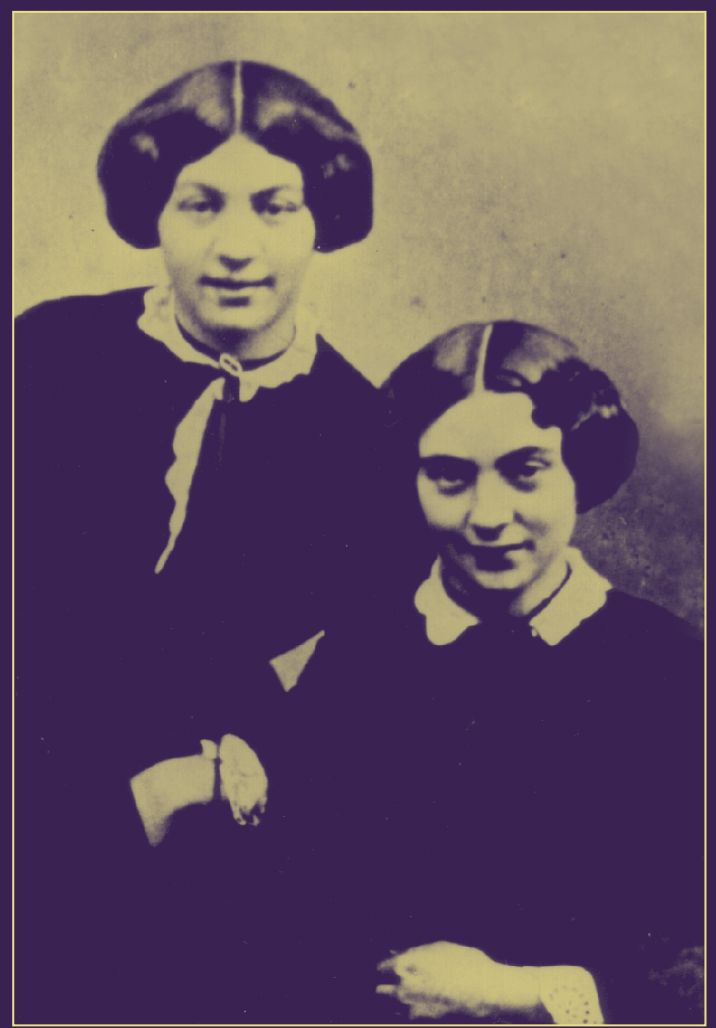


Meesterschap

IN TWEEVOUD

NOVELLEN EN SCHETSEN VAN

Rosalie EN Virginie

LOVELING 
De Amazone-reeks

onder redactie van Lia van Gemert en Piet Couttenier

Redactie voor dit deel: Lia van Gemert

In de Amazone-reeks zijn reeds verschenen:

(1999) Schenkeveld-van der Dussen, Riet en Annelies de Jeu (red.)

Gedichten van Anna Roemersdochter Visscher

ISBN 9053564136

(2001) Van Oostrum, Pim (red.)

't Zoet der eenzaamheid. Gedichten van Juliana Cornelia de Lannoy

ISBN 9053564756

(2001) Veltman-van den Bos, Ans en Jan de Vet (red.)

Aardenburg of de onbekende volksplanting in Zuid-Amerika.

Roman van Petronella Moens

ISBN 9053565329

(2004) Schenkeveld, Margaretha H. en Riet Schenkeveld-van der Dussen (red.)

Elize. Roman van Elisabeth Johanna Hasebroek

ISBN 9053566031

(2006) Paasman, Bert (red.)

Mijn landelijke lier. Poëzie en proza van Elisabeth Maria Post

ISBN 9789053568217

(2007) Hanou, André (red.)

Geschrift eener bejaarde vrouw. Elisabeth Bekker, Weduwe Wolff en Agatha Deken

ISBN 9789053564493 


\title{
MeEsterschaP IN TWEEVOUD
}

\section{NOVELLEN EN SCHETSEN VAN \\ Rosalie EN VIRGINIE \\ LOVELING}

\author{
Bezorgd en ingeleid \\ door Piet Couttenier en \\ Anne Marie Musschoot
}

Amsterdam University Press 
Deze serie wordt mede mogelijk gemaakt door financiële steun van het Prins Bernhard Cultuurfonds

Afbeelding omslag: detail uit foto van de drie gezusters Loveling: links Virginie, rechts Rosalie. AMVC-Letterenhuis Antwerpen en Archief Cyriel Buysse Genootschap Gent.

Ontwerp omslag: Geert de Koning, Kampen

Vormgeving binnenwerk: Paul Boyer, Amsterdam

NUR 621

ISBN 9789089640635

\section{() Amsterdam University Press, 2009}

Alle rechten voorbehouden. Niets uit deze uitgave mag worden verveelvoudigd, opgeslagen in een geautomatiseerd gegevensbestand, of openbaar gemaakt, in enige vorm of op enige wijze, hetzij elektronisch, mechanisch, door fotokopieën, opnamen of enige andere manier, zonder voorafgaande schriftelijke toestemming van de uitgever.

Voorzover het maken van kopieën uit deze uitgave is toegestaan op grond van artikel 16B Auteurswet 1912 jo het Besluit van 20 juni 1974, Stb. 351, zoals gewijzigd bij het Besluit van 23 augustus 1985, Stb. 471 en artikel 17 Auteurswet 1912, dient men de daarvoor wettelijk verschuldigde vergoedingen te voldoen aan de Stichting Reprorecht (Postbus 3051, 2130 KB Hoofddorp). Voor het overnemen van gedeelte(n) uit deze uitgave in bloemlezingen, readers en andere compilatiewerken (artikel 16 Auteurswet 1912) dient men zich tot de uitgever te wenden. 


\section{INHOUDSOPGAVE}

Inleiding 7

Korte biografie 7

Korte waarderingsgeschiedenis 8

Tussen realisme en naturalisme 10

Genderproblematiek 14

Verantwoording van deze editie 17

Bronnen voor de inleiding 20

Literatuur 21

Verantwoording van de illustraties 23

Novellen en SCHETSen VAN Rosalie Loveling 25

Meester Huyghe 26

Po en Paoletto 36

Iets over het onderwijs der vrouw 52

Het meesterschap 55

NOVELLEN VAN Virginie LOVELING 63

De kwellende gedachte 65

Meesterschap 85

Vrijheid - Blijheid 125

Plaatje Mulderman 149

Noten bij de teksten $\quad 157$ 


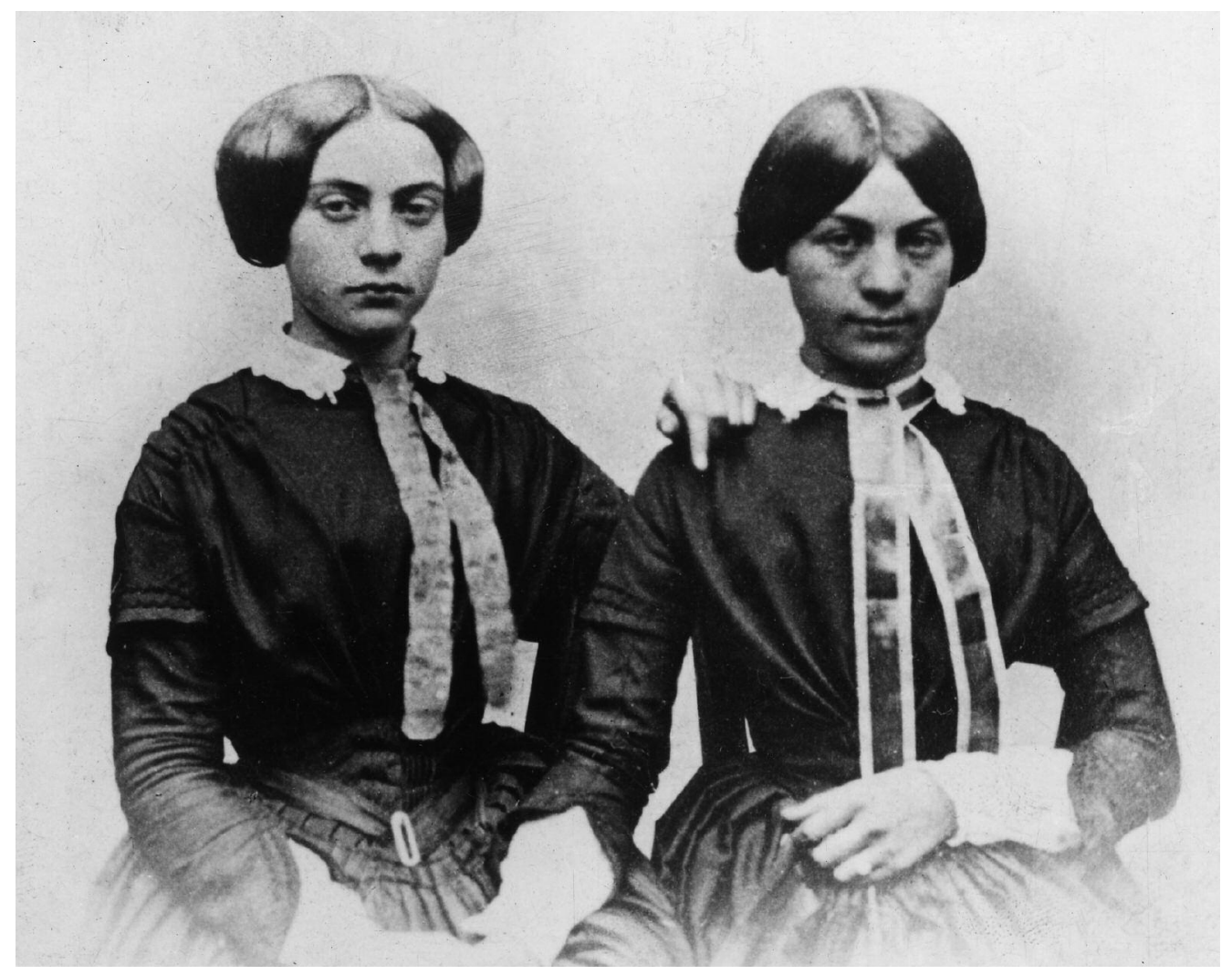




\section{INLEIDING}

\section{Korte biografie}

Rosalie (1834-1875) en Virginie Loveling (1836-1923), beiden geboren in Nevele (Oost-Vlaanderen), waren dochters uit het tweede huwelijk van Marie Comparé (1791-1879) met de uit Hannover (in Duitsland) afkomstige Herman Anton Loveling (1806-1846). Hij werd landmeter, griffier en schepen (lid van het dagelijks gemeentebestuur) van Nevele. Het gezin behoorde tot de landelijke bourgeoisie. Rosalie en Virginie hadden een oudere zus, Pauline Loveling (1832-1909), die de moeder zou worden van de schrijver Cyriel Buysse. Ook verscheidene andere leden van de uitgebreide familie waarvan Marie Comparé de stammoeder was, hadden literair talent of werden wetenschappers.

In de korte 'Biografie' die Virginie Loveling zelf opstelde in 1895 en die pas in 1963 werd gepubliceerd, noteerde ze dat haar moeder een 'zeer ontwikkelde vrouw' was, die de Franse filosofen 'grondig kende', gaarne Voltaire en Rousseau, en ook Cats las. Zij had in het bijzonder de regeringen van Frederik de Grote en van Napoleon I (met alle daarbij horende veldslagen) bestudeerd. Zij bracht al haar kinderen (de zusjes Loveling waren de jongsten van negen) een grote liefde voor de natuur en voor dieren bij. Ook hun vader, die volgens Virginie Loveling 'nagenoeg al de bijzonderste talen van Europa grondig geleerd' had, was 'een groot liefhebber van boeken' die 'schier alles kocht wat er verscheen'.

Een zeer tragisch en ingrijpend moment in het leven van de familie was toen vader Herman Anton Loveling zelfmoord pleegde, waarop in die tijd nog een groot taboe rustte. Daarna ging de moeder met haar drie dochters naar Gent wonen bij Cesar Fredericq, een van de zonen uit haar eerste huwelijk. De woning van deze arts was een centrum van intellectueel verkeer voor een groep Franssprekende, maar Vlaamsgezinde vrijzinnigen. De jonge meisjes Loveling, die eerder van hun vader privéonderwijs hadden gekregen en van hem al heel vroeg Duits leerden lezen en schrijven, kregen nu verder onderricht in het Frans van Cesar Fredericqs echtgenote Mathilde Huet, een Parijse die een diploma van onderwijzeres had.

In deze stimulerende omgeving begonnen Rosalie en Virginie vanaf hun vroege kinderjaren verzen te schrijven, die ze zelf met 'waterverfklompjes' illustreerden. Ze dweepten met Karel Lodewijk Ledegancks bundel Bloemen mijner lente en kenden de Reynaert-bewerking van J.F. Willems 'schier gans van buiten'. Die Reynaert is een editie waarvan het voorbericht in eigen tijd beschouwd werd als het manifest van de Vlaamse Beweging. Ook de bloem- 
lezing uit de gedichten van Tollens die Virginie in handen kreeg, werd met geestdrift uit het hoofd geleerd.

Pas toen ze al volwassen waren keerden de twee jongste meisjes naar Nevele terug, waar hun moeder ze al eerder met Pauline was voorgegaan. Intussen hadden de meisjes er genoegen in leren scheppen zelfstandig verschillende talen te leren, een gewoonte die ze voort zouden zetten. Naast het Frans en het Duits dat ze al kenden, studeerden ze ook Engels, Spaans, Italiaans, Deens en Zweeds. Rosalie studeerde zelfs Latijn en Servisch. De talenkennis van de zussen vormde uiteraard de basis voor een brede lectuur en permanent onderhouden intellectuele vorming; ze liet hen ook toe vertaalwerk op te nemen en te schrijven over de actualiteit in diverse landen. Hoewel Virginie plastisch talent had en enkele keren het atelier bezocht van een Gents schilder, bleek een artistieke carrière zelfs voor haar onmogelijk. Ze heeft het zelf over 'nog een rest van vooroordeel', dat stelt dat 'meisjes niet geschikt zijn voor het kunstenaarsvak'. Maar in hun schrijverscarrière kregen Rosalie en Virginie al heel vroeg steun en waardering. Hun kinderversjes werden gepubliceerd tussen 1846 en 1851 en vanaf 1853 begonnen ook 'ernstige' gedichten van hen in tijdschriften te verschijnen.

Virginie Loveling zou haar zus Rosalie bijna vijftig jaar overleven. In 1880 vestigde ze zich in Gent, waar ze nog een uitgebreid proza-oeuvre tot stand heeft gebracht in verschillende genres: romans, novellen, schetsen, verhalen voor kinderen, bijdragen over volkskunde, kritische en beschouwende stukken. Ze ondernam verschillende reizen, onder meer in 1900 naar Australië en cultiveerde veelvuldige contacten in het buitenland, bijvoorbeeld met de Duitse dichter en prozaschrijver Claus Groth. Een van die tochten verwerkte ze in haar literaire reisroman, Een winter in het Zuiderland (1890), waarin een fictief personage, tevens alter ego van de schrijfster, niet alleen indrukken en onverwachte ontmoetingen noteert, maar ook interessante gedachtewisselingen over allerlei levensbeschouwelijke en artistieke vraagstukken. Haar oorlogsdagboek, dat ze in de grootste geheimhouding en met gevaar voor eigen leven heeft bijgehouden tijdens de Eerste Wereldoorlog, behoort tot de meest aangrijpende, directe getuigenissen uit die jaren. Het werd in 1999 gepubliceerd onder de titel In oorlogsnood.

\section{Korte waarderingsgeschiedenis}

Al tijdens hun leven konden Rosalie en Virginie Loveling rekenen op de waardering van schrijvers uit hun omgeving. In Nederland waren critici als E.J. Potgieter, J. ten Brink en C. Busken Huet al vlug gecharmeerd door het schrijversduo uit Nevele, dat ze zeer bewonderden. Laatstgenoemde rapporteert in zijn Belgische reisherinneringen die in 1879 onder de titel Het land van Rubens verschenen, hoe Potgieter in 1871 een bezoek bracht aan de gezusters Loveling. Voor hun gedichten, schreef Potgieter hem, zou hij 'de 
halve nieuwe Vlaamse letterkunde' cadeau doen, een blijk van waardering die overigens ook duidelijk maakt dat Potgieter geen al te hoge dunk had van die nieuwe Vlaamse letterkunde. Gangmaker voor die waardering in het Noorden vormde inderdaad de poëzie van de Lovelings. De Groningse anthologist Lubbertus Leopold nam gedichten van hen op in zijn bloemlezing Uit Zuid-Nederland (1868) en kort daarna kwam het onder zijn impuls tot de publicatie van hun debuutbundel Gedichten (1870) bij uitgeverij J.B. Wolters. Een belangrijke rol in het Zuiden speelde de hiervóór al genoemde groep liberale en vrijzinnige intellectuelen uit het Gentse universitaire milieu met wie de zusjes door familiebanden waren verbonden, onder anderen François Huet, hoogleraar wijsbegeerte, Emile de Laveleye, hoogleraar politieke economie, Cesar (arts) en Paul (historicus) Fredericq en Julius Mac Leod, hoogleraar plantkunde. In dit milieu bestond een intense belangstelling voor de idealen van de Verlichting en voor de Vlaamse Beweging en er werd geijverd voor de vernederlandsing van het onderwijs. Ook de bemoeienissen van de Gentse literatuurcriticus en hoogleraar Jakob J.F. Heremans droegen bij tot de reputatie van het schrijvende zusterpaar. Al in 1874 introduceerde hij hun prozadebuut Novellen dat bij de Gentse uitgever Ad. Hoste verscheen. Hij prees hun sobere en artistieke stijl en wees erop dat ze een nieuwe vorm van literaire waarachtigheid introduceerden in het genre van de landelijke novelle. '[W]ij hebben hier waarheid, maar waarheid met bewonderlijke kunst en uiterste kiesheid voorgesteld', constateerde Heremans, en hij bracht dit nieuwe proza in verband met dat van Berthold Auerbach en George Sand, 'alsmede onze Hildebrand, Cremer en Tony'. Tony, of Anton Bergmann, was de auteur van het postuum verschenen Ernest Staas, advocaat (1874), door zijn tijdgenoten een 'Vlaamse Camera Obscura' genoemd.

$\mathrm{Na}$ het vroegtijdige overlijden van Rosalie in 1875 ontfermde Virginie zich over de literaire nalatenschap van haar betreurde zus en bouwde ze verder haar literaire carrière uit. Ze verwierf het imago van progressieve en gerespecteerde prozaïste en nog vóór de Eerste Wereldoorlog kreeg ze openbare erkenning. In 1896 ontving ze de Belgische vijfjaarlijkse staatsprijs voor Vlaamse letterkunde. In 1912 werd voor haar een grote hulde georganiseerd, waarvan Karel van de Woestijne een waarderend journalistiek verslag uitbracht in de Nieuwe Rotterdamsche Courant. Haar progressieve en openlijk liberaal-vrijzinnige standpunten stonden een positieve ontvangst van haar werk niet in de weg. Dat had veel te maken met de manier waarop Loveling de gendersjablonen ontweek die in Vlaams-België door de literaire critici over vrouwelijke auteurs waren ontwikkeld. Die reserveerden literaire genialiteit voor mannelijke creatieve kracht, terwijl ze de bijdrage van schrijfsters aan de vaderlandse letterkunde vooral loofden voor zover die met fijngevoeligheid en warmte, waarden beklemtoonden die met huiselijkheid en moederlijkheid werden geassocieerd. Virginie Loveling combineerde in haar 'androgyne' schrijversprofiel mannelijke rationaliteit met vrouwelijke 
kiesheid, kracht met empathie, analyse met reserve, waardoor ze gedurfde en vooruitstrevende standpunten kon innemen in het politieke en culturele debat zonder te choqueren. Toch zou ze bijvoorbeeld nooit in het openbaar optreden: bij officiële gelegenheden liet ze het steeds aan haar neef Paul Fredericq over om het woord te nemen en haar te vertegenwoordigen. Vanaf 1891 publiceerde Virginie ook in Nederland. Ze trad daarmee resoluut in het spoor van Vlaamse auteurs als Prudens van Duyse, Jan van Beers, Maria van Ackere-Doolaeghe, August Snieders en Hendrik Conscience, die al vroeger in de negentiende eeuw, met succes overigens, pogingen hadden ondernomen om toegang te vinden tot de grote Nederlandse literaire afzetmarkt. Daardoor was Virginie Loveling ook minder afhankelijk van de bijval bij het lezerspubliek in het Zuiden: ze kon zich vrijer opstellen tegenover de Vlaamse literaire kritiek. Haar romanoeuvre kan dan ook niet los worden gekoppeld van trends in de Noord-Nederlandse prozaliteratuur, in het bijzonder van het naturalisme, dat, veel meer dan het Vlaamse naturalisme, theoretisch was gefundeerd. Ook in het genre van de probleemroman, dat in Nederland succesrijker was dan in het Zuiden, vond zij aansluiting bij de ontwikkeling in het Noorden.

\section{Tussen realisme en naturalisme}

Vormde de verfijnde en pregnante poëzie van de Lovelings tot in de eerste helft van de twintigste eeuw een belangrijke factor in de vorming van hun literaire faam, nu is het toch vooral hun proza dat aanspraak kan maken op een vernieuwde interesse en esthetische waardering van de hedendaagse lezer. Hun literaire proza is van groot literair-historisch belang. In de Vlaamse literatuur maakten ze, samen met auteurs als Anton Bergmann en Jeanette Delcroix, een einde aan een soort literatuur die ten dienste werd gesteld van de vorming van een nationale identiteit en die in brede lagen van de bevolking de leesbehoefte en de alfabetisering diende te bevorderen. Met de Lovelings komt een lezer in het vizier die artistiek is ingesteld en die, met de nodige literaire bagage, persoonlijk en zonder bevoogding kennis wil maken met een modernere vorm van literatuur. Het is een literatuur die gekenmerkt wordt door een individuele stijl en waarin de confrontatie wordt aangegaan met actuele, intellectuele of filosofische vraagstukken. De overgeleverde idealen worden ter discussie gesteld, nieuwe wegen verkend. Rosalie en Virginie Loveling ontwikkelden met hun novellen en schetsen een dergelijke nieuwe vorm van literatuur en ze lieten zich daarbij vrij inspireren door Franse, Duitse en Noord-Nederlandse voorbeelden. Door hun privéopleiding in een welgesteld en intellectueel hoogstaand bourgeoismilieu verschilden ze grondig van de Vlaamse auteurs in hun omgeving. De doorsneeauteur in Vlaanderen diende zijn schrijverschap als een nevenactiviteit te organiseren. Hij was ook in hoge mate afhankelijk van de 
officiële defensieve standpunten die de Vlaamse cultuurflaminganten innamen tegenover de 'vreemde' omringende literaturen. Opvallend, en uitzonderlijk in hun tijd, was de openheid van de gezusters Loveling tegenover actuele literaire tendensen uit het buitenland. Dat kwam hun stijl ten goede. Ze schreven traditionele landelijke novellen, maar bij hun observatie van het dagelijkse leven en de mentaliteit op het Oost-Vlaamse platteland namen ze een grotere afstandelijkheid in acht. Ze analyseerden de toestanden ook scherper en vrijmoediger. De kwalijke gevolgen van overgeërfde machtsverhoudingen en vooroordelen konden daarmee nuchter en overtuigend worden neergezet.

Over het algemeen dragen de verhalen van de gezusters Loveling het karakter van documentaire studies van het dagelijkse leven van de Vlaamse landslieden, waarin zowel de traditionele standsverschillen als de volkscultuur (devoties, rituelen, gebruiken) een dominante rol spelen. Ook waar ze de Gentse burgerij en bourgeoisie als setting aanwendden, slaagden ze erin vormen van egoïsme en hypocrisie met ogenschijnlijke onbewogenheid te beschrijven. Dat betekent niet dat hun novellen en schetsen helemaal afrekenen met een traditionele manier van vertellen. Empathie en medeleven met gevallen van verongelijking op aarde leiden dikwijls tot aanklacht, uitgesproken ideologische standpunten en verontwaardigde tussenkomsten van de verteller. Individuele gevallen van misère of mislukking worden ook dikwijls nog tegen het licht gehouden van een algemeen geldende waarheid over het menselijke lot of een volkse wijsheid. Maar overwegend is toch de sobere verkenning van de lotsbestemming van individuen in een ontnuchterende, soms harde wereld. De verteller beschrijft meestal de personages vanuit een extern standpunt, maar dringt ook genoeg in het bewustzijn van die personages door om met het nodige realiteitseffect een zoektocht naar geluk en zelfstandigheid te verbeelden. De hoop wordt echter niet altijd ingelost. In sommige romans van Virginie Loveling wordt het verhaal verteld van vrouwen die zich ten koste van hun omgeving ontdoen van maatschappelijke vooroordelen en morele druk, zoals in Een dure eed van 1891, waarin de natuurwet van de liefde zegeviert op de traditioneel-idealistische visie dat de heldin wegkwijnt van verdriet of intreedt in het klooster als haar geliefde sterft. De roman Sophie (1885), over de schoolstrijd in Vlaanderen, vertelt hoe een vrouw erin slaagt, zij het met moeite, om in een omgeving van geestelijke en politieke intolerantie uiteindelijk levensbeschouwelijke onafhankelijkheid en gewetensvrijheid te bereiken. In andere, pessimistischer teksten wordt veeleer het tegenovergestelde bewaarheid. De verwachtingen leiden daar tot desillusie, bedrog, eenzaamheid en wanhoop. De roman Mijnheer Connehaye (1895) laat, ondanks het happy end, de verstikkende invloed van gedragscodes in het bourgeoismilieu zien. Soms slaat het noodlot hard toe. Zo zien de hoofdpersonages in de roman Erfelijk belast (1906) slechts in de zelfmoord een uitweg voor een situatie van uitzichtloze conditionering. 
Enkele van de hier opgenomen novellen illustreren die ontwikkeling, weg van een idealiserende weergave van de werkelijkheid naar een realistischer manier van schrijven. In 'Meester Huyghe' (1874) beschrijft Rosalie Loveling de grote geschiedenis in het prisma van het levensverhaal van de kleine man. De doordeweekse realiteit en het leven van een eenvoudige dorpsonderwijzer, eertijds een soldaat van Napoleon, verbergt een menselijk drama van verarming en vergetelheid waarmee de verteller in hoge mate sympathiseert. Die verteller is echter nergens opdringerig aanwezig, ook al legt die zeer gemakkelijk het verband tussen wat zich in het gemoed van het hoofdpersonage afspeelt en het algemene niveau van het menselijke hart. De menselijke vergankelijkheid stemt ten hoogste tot weemoed. In de snelle opeenvolging van gebeurtenissen - met korte, afgemeten zinnen vertelt het verhaal zich als het ware vanzelf, transparant, zonder de opdringerige aanwezigheid van een gidsende verteller. 'Po en Paoletto' (1875) bezit diezelfde ingehouden en meewarige toon die veel te maken heeft met de gereserveerde opstelling van de verteller. Het realisme blijkt ook uit de zo getrouw mogelijke weergave van het taalgebruik van de personages, de minutieuze beschrijvingen die tijdelijk het verhaalverloop opschorten en de observatie van de plattelandscultuur, zoals die zich in het verenigingsleven en de feestviering manifesteert.

Virginie zette na het overlijden van Rosalie de evolutie alleen voort. Dat is al duidelijk in de novelle 'De kwellende gedachte' van 1875. Zoals in veel van haar latere romans laat Loveling hier de lezer meteen binnentreden in de handeling van het verhaal - in medias res - en in de gedachten- en gevoelswereld van een vrouwelijk hoofdpersonage dat voor een opdracht wordt geplaatst of een reeks moeilijkheden moet overwinnen. Hier gaat het om de oplossing van een familieraadsel in de vorm van een whodunit. De verteller beperkt zijn kennis zoveel als mogelijk tot de grenzen van dat ene personage, niet alleen om de spanning te verhogen, maar ook om de aandacht van de lezer te vestigen op de kern van de zaak: het waarachtige beeld van een vrouw die zich in de snelle opeenvolging van dramatische gebeurtenissen moet handhaven, te midden van een hachelijke en door mannen gedomineerde wereld.

Virginie Loveling verleent de karakterisering van haar personages nog meer realistische waarschijnlijkheid door psychologische verschijnselen een fundament van waarheid te verlenen volgens de toenmalige inzichten van de natuurkundige en medische wetenschappen. In 'De kwellende gedachte' worden verwante karaktereigenschappen van personages, en het op te lossen raadsel dat dit met zich meebrengt, vertaald in termen van familiale erfelijkheid. Ook in andere hier opgenomen verhalen, net zoals in veel van Virginies latere romans, worden wetenschappelijke inzichten verwerkt over de darwinistische evolutieleer en het determinisme op basis van erfelijkheid, degeneratie en invloed van het milieu.

Virginie Loveling gaat in haar romans en verhalen overigens een dialoog aan met dat natuurwetenschappelijke discours, dat toen in intellectuele 
kringen in West-Europa en vogue was en dat in de experimenten van het literaire naturalisme, vooral in Frankrijk en Nederland, een cruciale rol speelde. Wellicht het duidelijkst is dat het geval in Een revolverschot (1911), een een hoogtepunt van Virginie Lovelings romanoeuvre. De schrijfster komt hier dicht bij het type van de Franse naturalistische roman die, in overeenstemming met de voorschriften van Emile Zola, een wetenschappelijk experiment uitvoert op geconditioneerde individuen in een welbepaald milieu. De plot is van het Zola-type, waarbij de fysieke en morele aftakeling van een geval vanuit een voorafbepaalde omstandigheid klinisch wordt geanalyseerd. De fysiologische en erfelijke determinering van het nerveuze hoofdpersonage, Marie Santander, veroorzaakt er een kettingreactie van onvermijdelijke gebeurtenissen, die dromen van huwelijksgeluk en moederliefde doen omslaan in ziekelijke fantasmen, emotionele oorlog, haat, moord en waanzin. In dit pessimistische universum zijn er weinig alternatieven of sporen van mogelijke regeneratie, tenzij die te vinden zouden zijn in de kracht van de natuur en het primitieve volk, waarvan de traditionele cultuur met veel interesse wordt gedocumenteerd. Primitieve en brute toestanden op het platteland worden daarbij dikwijls, zoals in het postuum gepubliceerde verhaal 'Plaatje Mulderman', met een mengeling van fascinatie en afschuw door de verteller op een zekere afstand geobserveerd en vastgelegd. In die studies overbrugt de verteller een kloof tussen heel verschillende talen en culturen met het oog op de verkenning van een algemeen menselijke thematiek.

In hun werk tonen Rosalie en Virginie Loveling zich echter geen blinde adepten van de moderne wetenschap en de evolutieleer, noch van het theoretische en experimentele naturalisme. Zo vertoont het hier opgenomen verhaal 'Meesterschap' van Virginie Loveling ontegenzeggelijk verwantschap met een naturalistisch wereldbeeld. Ook daarin speelt zich een ware struggle for life af waarbij, conform de darwinistische theorie van de seksuele selectie en de fysiologisch bepaalde karakters, de viriele, krachtige man streeft naar dominantie en macht over de vrouw. Maar Loveling legt ook andere accenten in het evolutionair gedachtegoed. Opvallend is opnieuw de nieuwsgierige, haast encyclopedische interesse voor de volkscultuur, met de verklaring in voetnoten van de gebruiken en het taalidioom van de OostVlaamse plattelandsbewoner. De lezer, die zeker tot de meer geprivilegieerde klassen behoorde, kon hier kennismaken met de vreemde gewoonten en omgangsvormen van de boerenbevolking. Maar het verhaal nodigt door zijn directe vertelwijze ook uit tot inleving. Het andere is ook gedeeltelijk het eigene: het gaat om een herkenbaar geval van patriarchale macht, het ongelijk verdeelde familierecht en het daarmee samenhangende autoritaire beheer van het fortuin. De projectie in een primitieve samenlevingsvorm en cultuur geeft de verteller de mogelijkheid tot extreme uitvergroting. Het immobilisme leidt tot moord. Tragisch is de situatie van de vrouw, Trezeken, die onderdanig is aan het mannelijke meesterschap, maar dat ook uit bere- 
kening doet. Op die manier relativeert Loveling de seksegebonden patronen. Man én vrouw delen in het verhaal dezelfde hebzucht. Beiden zijn medeplichtig door hun drang naar geld en macht. De verteller schuift hier laconiek een veroordelend commentaar tussen: 't Is voor onze kinderen, zei zij - die eeuwige ontschuldiging der ouderen voor elke loense daad, voor al wat hebzucht, gierigheid of onrechtvaardigheid zich onderstaan te doen.' (p. 121) De tragiek van het verhaal wordt nog vergroot doordat het grootste slachtoffer uiteindelijk het zoontje uit het gezin blijkt te zijn, dat als getuige van de moord en 'kind van de rekening', de schuld op de volgende generatie overdraagt.

\section{Genderproblematiek}

Dat de Lovelings over de geijkte en aangeboren genderpatronen duidelijk alternatieve opvattingen hadden, blijkt zowel uit hun literair als uit hun essayistisch proza. In beide genres ontwikkelden ze beelden van mannelijkheid en vrouwelijkheid die afwijken van de norm. Zo treden in de meeste naturalistische verhalen en romans ook atypische mannen op die week en gevoelig zijn. Maar daartegenover staat dat de gezusters Loveling ook veel krachtige vrouwen opvoeren die het heft in eigen handen nemen, die hun leven zelf inrichten en streven naar onafhankelijkheid. Om één voorbeeld te noemen: in de roman Idonia (1891) portretteert Virginie een zelfbewuste vrouw, echtgenote van een dorpsnotabel, die op eigen houtje en ondanks de reserves van haar man de opvoeding op zich neemt van een behoeftig dorpsmeisje, de dochter van haar verarmde hovenier. Het verhaal eindigt navrant als uiteindelijk ook de vrouw ontdekt dat het meisje het natuurlijke kind van haar echtgenoot blijkt te zijn, een op zijn zachtst gezegd verrassende en taboedoorbrekende ontknoping die de man dwingt tot schuld en boete.

Heel opmerkelijk in dit verband is ook 'Het meesterschap', een tekst van Rosalie uit 1874 die in manuscript werd nagelaten en pas in 1986 is uitgegeven. In deze beschouwing geeft Rosalie Loveling kritisch commentaar op The Subjection of Women van John Stuart Mill, een filosofisch-beschouwend werk uit 1869 waarin de positie van vrouwen in de moderne Engelse maatschappij onder de loep wordt genomen. Vrouwen hebben nauwelijks of geen rechten, stelt Stuart Mill, zowel in het huwelijk als in het beroepsleven vervullen zij een slachtofferrol. Rosalie Loveling toetst Stuart Mills theorie aan de werkelijkheid en komt tot de conclusie dat zijn sombere beeld van de vrouw vals is: zij meet de afstand tussen wet en realiteit en beschrijft het subtiele spel van machtsverhoudingen dat man en vrouw met wederzijds begrip in het burgerlijke huwelijk voor de buitenwereld opvoeren. De masculiene suprematie in het huwelijk en binnen het gezin noemt zij slechts een schijn die de werkelijkheid van de vrouwelijke heerschappij verbergt. De man wordt echter door Loveling - anders dan Stuart Mill, die 
pleit voor gelijkwaardigheid en gelijke behandeling - wel degelijk in geestelijk opzicht boven de vrouw geplaatst, wat meteen een reden is om de man op zijn grote verantwoordelijkheid te wijzen. In een andere hier eveneens opgenomen tekst, 'Iets over het onderwijs der vrouw' (1871), brak Rosalie Loveling al eerder een lans voor de intellectuele ontwikkeling van de vrouw. Zij verdedigt het recht van jonge vrouwen op geestelijke ontwikkeling en degelijk onderwijs. Het van staatswege ingerichte middelbaar onderwijs (met de wet van 1850) was alleen voor jongens toegankelijk. Rosalie pleit voor de oprichting van meisjesgymnasia die gelijkwaardig zouden zijn aan de humaniora voor jongens. Met die standpunten toont Rosalie aan dat ze op de hoogte was van acties van enkele progressieve vrouwen in België, zoals Zoé en Isabelle Gatti de Gamond. Over het algemeen werden vrouwen tijdens de negentiende eeuw teruggedrongen in de privésfeer als echtgenote en moeder ten koste van openbare 'mannelijke' activiteit en creativiteit. De vrouwenbeweging die zich in België vanaf de jaren 1860 ontwikkelde, zag uitgerekend in het meisjesonderwijs de hefboom bij uitstek voor vrouwenemancipatie.

Interessant is hoe Virginie Loveling de genderproblematiek van haar tijd uiteindelijk in literatuur vertaalt en te kijk stelt. Dat bleek al uit het verhaal 'Meesterschap'. Het bijzonder sterke verhaal 'Vrijheid - Blijheid' uit de bundel Jonggezellen levens (1907), toont dat nog beter aan. Loveling portretteert hier op indrukwekkende en beklijvende wijze een vrouw die binnen het instituut van het burgerlijke huwelijk aan de tirannie van de man onderworpen raakt. Uit liefde getrouwd, wordt ze in haar vrouwelijke fijngevoeligheid en kiesheid door de mannelijke overmacht in de symbolische omgeving van een varkensslachterswinkel gaandeweg geheel en al overmeesterd. Uiteindelijk legt ze zich bij dat meesterschap neer. 'Natalie' neemt de identiteit aan van 'vrouw Rogiest' en wanneer haar man sterft, is ze niet eens meer in staat om haar vrijheid in blijheid op te nemen. Het verhaal van die degenererende evolutie, bijwijlen met schokkende scènes van onderwerping en vernedering, is complexer dan het op het eerste gezicht lijkt. Soms wordt de machtsstrijd, conform de naturalistische code, voorgesteld als een natuurlijke zaak van survival of the fittest of het recht van de sterkste. Vooral in het begin van het verhaal lijkt het of de schuld van de ongelijke positie van de vrouw volledig op conto van de mannelijke bruut wordt geschreven. Maar gaandeweg worden andere facetten in stelling gebracht: de vrouw mist een gedegen intellectuele opleiding om weerbaar te zijn, ze schikt zich te vlug in haar dienende rol en puurt slechts nog eigenwaarde uit heldhaftig gedragen verborgen verdriet. Het hoofdpersonage minimaliseert zelfs haar lijden tegenover haar eigen kinderen: “' $t$ is niets, 't is niets," zei ze, haar wrang geheim ontdekt ziende, "een woordje met vader"' (p. 137). Het beroep op volksgezegden ('Och kind, het is stil waar het nooit waait'; p. 137) werkt hier als een drogreden die een diepe wonde helpt verbergen. Haar lijdzaamheid prikkelt zelfs het tirannieke gedrag van de man en maakt elke 
kans op respect van zijn kant ongedaan. De verteller lijkt uiteindelijk te suggereren dat de aangeboren karakterstructuur bepalend is. Door hun aanleg komen man en vrouw in een cirkel van onderdanigheid en overheersing terecht waaruit ze niet meer kunnen ontsnappen. Door haar natuur en haar constitutie is de vrouw medeverantwoordelijk voor haar onderdrukking, het is haar 'lot'. Met die 'naturalistische' voorstelling wordt op paradoxale wijze de feministische kritiek op de geïnstitutionaliseerde ongelijkheid ontkracht die de oorzaak in de burgerlijke maatschappelijke orde legt, een denkpiste die de verteller elders in het verhaal lijkt te volgen. Die meerduidigheid moet de toenmalige lezer ongetwijfeld tot nadenken hebben gestemd. Zij kon voor verwarring of ontkenning zorgen. Maar ook voor de lezer van nu blijft van een dergelijke tekst een fascinerende werking uitgaan. 


\section{VERANTWOORDING VAN DEZE EDITIE}

\section{Overzicht van de basisteksten}

Rosalie Loveling

Meester Huyghe. In: Novellen van Rosalie en Virginie Loveling. Gent, Algemeene Boekhandel van Ad. Hoste 1874 [eerste druk], 149-172.

Po en Paoletto. In: Nieuwe novellen van Rosalie en Virginie Loveling. Gent, Algemeene Boekhandel van Ad. Hoste 1876 [eerste druk], 115-174.

Iets over het onderwijs der vrouw. In: Polydoor \& Theodoor en andere novellen en schetsen van Rosalie en Virginie Loveling. Gent, Algemeene Boekhandel van Ad. Hoste 1883 [eerste en enige druk], 201-209.

Het meesterschap. In: Mededelingen van het Cyriel Buysse Genootschap II. Gent, Cyriel Buysse Genootschap 1986, 21-29; opgenomen als bijlage in A. van Elslander, 'Rosalie Loveling: enkele aanvullende gegevens'; aldaar afgedrukt naar UBGent, Hs 3423/11.

Virginie Loveling

De kwellende gedachte. In: Nieuwe novellen van Rosalie en Virginie Loveling. Gent, Algemeene Boekhandel van Ad. Hoste 1876 [eerste druk], 237-282.

Meesterschap. In: Virginie Loveling, Jonggezellen Levens. Aalst, De SeynVerhougstraete z.j. [1907; eerste druk], 65-147.

Vrijheid - blijheid. In: Virginie Loveling, Jonggezellen Levens. Aalst, De SeynVerhougstraete z.j. [1907; eerste druk], 149-201.

Plaatje Mulderman. In: Virginie Loveling, Van hier en elders. Gent, Boekhandel Van Rysselberghe \& Rombaut 1925, 75-89. 


\section{TEKSTVERANTWOORDING}

Alle teksten zijn afgedrukt naar de eerste druk of de eerste publicatie. Waar meerdere drukken voorhanden zijn wees vergelijking uit dat er geen substantiële wijzigingen werden aangebracht in de herdrukken. Om de leesbaarheid te verhogen werden, conform het gebruik in de Amazonereeks, spelling en interpunctie gemoderniseerd. Daarbij werden niet alleen de verbuigingsvormen geschrapt en genitiefvormen vervangen door een omschrijving met 'van'. Ook werd het af of aan elkaar schrijven van woorden aangepast aan het moderne gebruik ('ineens', 'eraan', 'opeens', 'nietwaar', 'tevergeefs' e.d.) en werden verouderde vormen als 'weder,' 'neder,' 'mede', 'zelve' vervangen door hun hedendaags equivalent. De uitdrukking 'te huis' werd aangepast tot 'thuis'; 'heur' is vervangen door 'haar' en 'broeder' door 'broer'. Het Vlaamse taaleigen - op zich ook vaak verouderd - wordt verklaard in de 'Annotaties bij de tekst'. In 'Het meesterschap' van Rosalie Loveling werden de editeursingrepen van A. van Elslander overgenomen, maar de tekst werd nog eens gecollationeerd met het handschrift, wat nog een enkele correctie opleverde.

Met dank aan de studenten die deelnamen aan seminarieoefeningen over Loveling in de Master Taal- en Letterkunde: Nederlands en Westerse literatuur aan de universiteiten van Antwerpen en Leuven, in de academiejaren 2005-2006 en 2008-2009.

\section{LIJST VAN EDITEURSGREPEN}

Meester Huyghe

[p., r.]

26, 24 vanzelf $<$ van zelfs

28, 17 oprichten $<$ oprechten

29, 1 alle $<$ allen

34, 9 zonder dat $<$ zonderdat

35, 3 doodsklok $<$ doodklok

\section{Po en Paoletto}

$\begin{array}{rrl}37, & 21 & \text { nog }<\text { noch } \\ 40, & 18 & \text { ontstoken }<\text { ontsteken } \\ 46, & 32 & \text { herkennen }<\text { erkennen } \\ 47, & 32 & \text { tenminste }<\text { ten minste } \\ 48, & 1 & \text { XI }<\text { IX } \\ 50, & 20 & \text { loden }<\text { lode }\end{array}$


Het meesterschap

55,4 formule $<$ formul

55, 18 van de zijde $<$ van zijde

55, 28 jacht $<$ jagd

56,17 meester is, $<$ meester is

57, 16 mannen $<$ mans

58, 38 Mr Bruis $<$ Mr Bruin (was correct in hs.)

59, 23 degenen $<$ degene

59,42 aan te lachen $<$ aan het lachen

De kwellende gedachte

72,18 sommige $<$ sommigen

72, 18 andere $<$ anderen

72, 18 Enige $<$ Enigen

72, 20 Sommige $<$ Sommigen

72,20 andere $<$ anderen

72, 36 haar weinig $<$ haar, weinig

80,39 enige $<$ enigen

Meesterschap

91, 35 uiteenstoof. < uiteenstoof;

95, 24 geplaatst, < geplaatst.

106, 6 formule $<$ formuul

109, 28 ontzien $<$ ontzen

112, 4 grove woorden, $<$ grove woorden

114, 32 halsstarrig $<$ halstarrig

Vrijheid-Blijheid

133, 6 bruiste $<$ bruisde

138,18 vakantie $<$ vancantie

143, 30 geëerbiedigde < geërbiedigden

144, 18 wiens $<$ wier

145,2 te pletter $<$ te pletten

148,3 witgeruite $<$ witgeruitte

In de basistekst ontbreekt hoofdstuknummer 10. De nummering is aangepast.

Plaatje Mulderman

153, 33 nadat heel $<$ nadat, heel 


\section{BRONNEN VOOR DE INLEIDING}

Biografische gegevens zijn te vinden bij Van Elslander 1963 en 1992 ; en uitgebreid bij Stynen 1997.

De getuigenis van Potgieter is aangehaald in Busken Huet 1881, 261. De waarderende brieven van Jan ten Brink worden bewaard in de Universiteitsbibliotheek Gent. (Hs. 3426, in de mappen C, D, H en P)

Voor een verkenning van de reisverhalen: zie Couttenier 2003; over Loveling 56-58.

Over de receptie van het werk en het 'androgyne schrijverschap' van Virginie Loveling: zie Vandenbussche 2008 (hoofdstuk 9 in Vandenbussche 2009). Over het verband tussen vrouwen, schrijverschap en het sekse-/ gendersysteem: Reymenants 2005. Over schrijvende vrouwen in de Nederlandse letterkunde: Met en zonder lauwerkrans 1997, in het bijzonder in Vlaanderen: Couttenier 2001. De opvattingen over de vrouw in de Nederlandse letterkunde zijn onderzocht in Streng 1997 en Van Dijk 2001. Toegespitst op de novellen en schetsen van Rosalie Loveling: Christiaens 1999. Informatie over het verband tussen meisjesonderwijs en vrouwenbeweging in België is ontleend aan Deneckere 2005, 612-624; over Loveling: 612. 


\section{LITERAT UUR}

Ameel, T., 'Ja, een vrouwmensch als een linde'. Virginie Loveling versus vrouwbeeld en visies op de band tussen sekse en kunstenaar-en schrijversschap van het fin de siècle. Leuven 2006. Onuitgegeven licentiaatsverhandeling.

Baekelmans, L., Vier Vlaamsche prozaschrijvers. Pieter Frans van Kerckhoven, Domien Sleeckx, Reimond Stijns, Virginie Loveling. Antwerpen 1931.

Basse, M., Het aandeel van de vrouw in de Nederlandsche letterkunde II. Gent 1921, 73-220.

Busken Huet, C., Het land van Rubens. Belgische reisherinneringen. Amsterdam 1881(1879).

Christiaens, B., 'Van De eerste opvoeding tot Het meesterschap. Over vrouwen in de novellen van Rosalie Loveling', in: Mededelingen van het Cyriel Buysse Genootschap 15 (1999), 139-202.

Couttenier, P., 'Rosalie Loveling: de betreurde vriendin'; 'Virginie Loveling: een geletterde dame’, in: Met en zonder lauwerkrans 1997, 937-946; 947-952.

Couttenier, P., 'Women writing in 19th-century Flanders', in: S. van Dijk e.a. (red.), Writing the history of women's writing. Toward an international approach. Amsterdam 2001, 21-27.

Couttenier, P., 'Hoe ik bijna een Robinson werd: Vlaamse reisverhalen uit de negentiende eeuw', in: E. Brems e.a. (red.), Ken ik U niet? Over het vreemde en de vreemdeling in de Nederlandse literatuur. Leuven 2003, 25-64.

Deneckere, G., 'Nieuwe geschiedenis van België 1878-1905', in: E. Witte, J.-P. Nadrin, E. Gubin en G. Deneckere, Nieuwe geschiedenis van België I: 18301905. Tielt 2005, 447-657.

Dijk, H. van, 'In liefdeleven ligt gansch het leven.' Het beeld van de vrouw in het Nederlands realistisch proza, 1885-1930. Assen 2001.

Elslander, A. van, De 'biografie’ van Virginie Loveling. Gent 1963.

Elslander, A. van, 'Rosalie Loveling: enkele aanvullende gegevens', in: Mededelingen van het Cyriel Buysse Genootschap 2 (1986), 7-29.

Elslander, A. van, De gezusters Loveling. Gent 1992.

Elslander, A. van, en A.M. Musschoot, 'Correspondentie van de gezusters Loveling. Brieven van en aan Paul Fredericq', in: Mededelingen van het Cyriel Buysse Genootschap 9 (1993), 67-175 en 10 (1994), 31-156. 
Met en zonder lauwerkrans. Schrijvende vrouwen uit de vroegmoderne tijd 1550-1850: van Anna Bijns tot Elisa van Calcar. (Red.) R. Schenkeveld-van der Dussen, K. Porteman, P. Couttenier, L. van Gemert e.a. Amsterdam 1997.

Musschoot, A.M., 'Virginie Lovelings Revolverschot: een herladen visie', in: Yang 20 (1984) februari, 6-9.

Musschoot, A.M., 'Correspondentie van de gezusters Loveling. Brieven van en aan Frans de Cort (1869-1875), in: Mededelingen van het Cyriel Buysse Genootschap 20 (2004), 67-90.

Piette, H., Les sœurs Loveling. Rosalie et Virginie, deux grandes figures féminines des lettres flamandes. Brussel 1942.

Reymenants, G., "“Den invloed der vrouw in de samenleving.” Waarom vrouwen in Van Nu en Straks ontbreken', in: R. de Bont, G. Reymenants en H. Vandevoorde (red.), Niet onder één vlag. Van Nu en Straks en de paradoxen van het fin de siècle. Gent 2005, 195-209.

Sintobin, T. “"Men” heeft altijd gelijk. Over het gebruik van gnomische formules in fin-de-siècleproza in Vlaanderen', in: Nederlandse letterkunde 13 (2008), 3, 185-203.

Streng, T., Geschapen om te scheppen? Opvattingen over vrouwen en schrijverschap in Nederland, 1815-1860. Amsterdam 1997.

Stynen, L., Rosalie en Virginie. Leven en werk van de gezusters Loveling. Tielt 1997.

Vanacker, D., 'De schoolstrijd van Virginie Loveling', in: V. Loveling, Sophie. Gent 1999, 5-46; eerder in Mededelingen van het Cyriel Buysse Genootschap 3 (1987), 91-136.

Vandenbussche, L., G. Vandermassen, M. Demoor en J. Braeckman, 'Darwin achterna? Erfelijkheid en evolutietheorie in het œuvre van Virginie Loveling', in: Mededelingen van het Cyriel Buysse Genootschap 23 (2007), 177-192.

Vandenbussche, L., " Dat ik de broek aan heb ziet gij." Het "androgyne” schrijverschap van Virginie Loveling (1836-1923)', in: Nederlandse letterkunde 13 (2008), 1, 67-87.

Vandenbussche, L., Het veld der verbeelding. Vrijzinnige vrouwen in Vlaamse literaire en algemeen-culturele tijdschriften (1870-1914). Gent 2009.

Vanheste, B., 'De gezusters Loveling: een vrouwelijk wonder', in: W. Waterschoot e.a., Literatuur ${ }^{*}$. Tot eind negentiende eeuw [Culturele Geschiedenis van Vlaanderen o.r.v. A.G.H.A. Baart en J. Louage, 8]. Deurne 1983, 138-141.

Wauters, K., 'De tragische levensvisie van Virginie Loveling', in: K. Wauters (red.), Verhalen voor Vlaanderen. Aspecten van het Vlaamse fictionele proza tot aan de Tweede Wereldoorlog. Kapellen 1997, 111-138. 


\section{VERANTWOORDING VAN DE ILLUSTRATIES}

p. 6

Rosalie (links) en Virginie (rechts) ca. 1850. Foto E. Van Damme Gent. AMVC-Letterenhuis Antwerpen L 863/P.

p. 62

Virginie Loveling, frontispice in Idonia, Haarlem 1891. Exemplaar Erfgoedbibliotheek Hendrik Conscience Antwerpen, C 28997.

p. 64

Virginie Loveling, borststuk, deels getekend, datum onbekend. Foto E. Barbaix Gent. AMVC-Letterenhuis Antwerpen B 212/P.

p. 84

Virginie Loveling, borststuk in profiel, sepiakleurig, ca. 1920. AMVC-Letterenhuis L 863/P. 

Novellen EN SCHETSEN VAN

Rosalie Loveling 


\section{Meester Huyghe}

Meester Huyghe was een oude man, groot en mager. Vóór een tiental jaren woonde hij hier nog met zijn vrouw op het dorp, in een laag, vriendelijk huisje, een weinig van de andere verwijderd, met witgekalkte muur en grote wijngaard op het dak. Men noemde hem nog altijd Meester, omdat hij vroeger school gehouden had. $\mathrm{Nu}$ zijn beiden heen, hij en zijn oude vrouw: andere mensen wonen in zijn huisje, en kleine kinderen spelen er voor de deur in het zand.

De Burgemeester vertelde nog dikwijls aan zijn kinderen, dat hij daar school had gegaan, als hij een knaap was, en wat vreugde de scholieren op onnozele-kinderendag en Sint-Gregorius ${ }^{1}$ hadden. Hij zelf had eens de eerste prijs behaald om een brief op rijm te schrijven; hij kende hem nog van buiten:

Meester Huyghe, met al uw bedrijf,

Als gij slaat, gij slaat wat stijf;

Maar ' $k$ moet het zeggen te uwer eren,

Gij doet uw best om ons te leren.

Meester Huyghe sloeg de kinderen niet; maar hij had dat voor het rijm gezet, zei hij. De andere knapen waren er jaloers over, en zeiden, dat zijn vader hem geholpen had.

Meester Huyghe had allengskens zijn scholieren verloren: de ene na de andere was naar de gemeenteschool gegaan, ${ }^{2}$ en alzo kwam het eindelijk vanzelf, dat hij geen school meer hield. Beatrice, zijn vrouw, was er niet kwaad om: 'Meester Huyghe werd zo oud, en het was zo lastig,' zegde zij. Ook maakten de kinderen de vloer zo vuil, en zij zouden zonder dat wel leven kunnen.

II

Meester Huyghe had een stukje land achter zijn huis: daarop groeiden zijn aardappelen; hij plakte ook dozen van bordpapier voor de mensen, en vermaakte hun regenschermen; Beatrice hielp hem daarin. Hij zou ook wel een ruit in een venster gestoken hebben, als het zo kwam, of een uurwerk nagezien, waar iets aan scheelde. Daarmee leefden zij nu stillekens voort. 
Beatrice was verheugd over de stilte in haar huisje, sinds al die kinderen er dooreen hun les niet meer luidop leerden; het scheen haar groot, nu dat al de houten banken eruitgenomen waren. Zij zat op haar laag stoeltje aan het venster te naaien, terwijl Meester Huyghe met de spa naar het land was, en sloeg van tijd tot tijd de ogen eens op door haar grote ronde brilglazen. Haar kasken ${ }^{3}$ en haar tafel waren wit geschuurd, en de glazen van de prenten, die aan de muur hingen, blonken in het zonnelicht. Daar hechtte Meester Huyghe grote prijs aan; hij had ze gekocht, toen hij getrouwd was: het waren de veldslagen van Napoleon. ${ }^{4}$ Op het kasken stond ook een klein gebronzeerd standbeeld van de grote veldheer, met gekruiste armen en hoge laarzen.

Meester Huyghe had Napoleon gediend, zoals men zegt; hij was er fier op, vooral wanneer hij des zondags uitging en zijn bronzen medailleken van St. Helena op zijn bruine frak ${ }^{5}$ hechtte: dat was zijn ereteken.

In het dorp waren er nog een tiental andere Napoleonisten; zij hadden zelfs een maatschappij gesticht en hadden hun vaandel en hun bijeenkomsten in een herberg.

Meester Huyghe wist zoveel te vertellen; want hij had, zoals men zegt, de wereld rondgereisd: nu zat hij hier uit te rusten. Des avonds in de hete zomerdagen, kwamen de jonge mannen uit het dorp, van welke er vele nog bij hem ter school hadden gegaan, gewoonlijk aan zijn deur zitten; - dat waren als zijn kinderen - de enen op een stoel, de anderen op de drempel, er waren er, die op het plankier ${ }^{6}$ lagen. Toen vertelde Meester Huyghe aan al die jongelieden, die daar niet van wisten te spreken, van uit zijn jeugd, en wat het dan heette soldaat te worden. Als hij in het lot gevallen was ${ }^{7}$ en vertrekken moest, was hij blij, dat zijn moeder niet meer leefde, zegde hij: 'het was naar de slachtbank gaan.'

Hij had de veldheer nooit gezien, maar in het leger die bewondering voor hem gekregen, welke aanstekend was, en vertelde nu zo gaarne van al de gevechten, die hij had bijgewoond, en hoe zijn kameraden in de sneeuw versteven waren, en hoe zij al slapend voortgingen, terwijl zij beurtelings elkaar ondersteunden. Hij vertelde van de veldslag, die zij verloren hadden, ofschoon zij zich zo dapper hadden verweerd; zij hadden, zei hij, tot in de straat gevochten, en man voor man.

De jongelieden hoorden dat gaarne, omdat Meester Huyghe het altijd gelijk vertelde, en er niets bijvoegde. Het gebeurde soms, dat er een paar andere Napoleonisten bij zaten, die ook aan het vertellen gingen; maar deze spraken van zulke wonderbare zaken, dat Meester Huyghe zich niet houden kon van glimlachen, als de jonge mensen hem vroegen, of dat alles waar was.

In Breslau was Meester Huyghe lang krijgsgevangen geweest, en hij had bij een oude kleermaker gewoond. Hij zou de goede vrouw, die hem als een zoon behandeld had, nog eens willen zien, zei hij soms, zonder er eens aan te denken, dat deze reeds sinds vele jaren dood moest zijn. Het was alsof hij herleefde telkenmale hij van die tijd sprak. 
Beatrice kon toch zijn bewondering voor de grote veldheer niet delen: 'zovele mensen gestorven voor één mens!' zei zij, en zij huiverde, als zij eraan dacht, wat rekening die in de dag des oordeels ervoor zou moeten geven!

\section{III}

Meester Huyghe had Beatrice gekend, vóór hij naar de oorlog trok, en had haar gevraagd om te wachten, tot hij terug zou keren. Zij had gewacht. Het scheen haar niet mogelijk, dat hij er blijven zou, en nochtans zij bleven er meest allen; maar het is somtijds, alsof het ongeluk daar niet gaat, waar het niet verwacht wordt. Beatrice had het niet verwacht, en het was niet gekomen. Zij had er vast op gerekend, dat hij weerkeren zou, en hij ook. Zij kende hem bijna niet meer, toen hij terugkwam. Het heeft iets bijzonder zoets iemand, aan wie men veel gedacht heeft, na jaren weer te zien: een ander mens en toch dezelfde; men heeft er vermaak in gade te slaan, hoe wel zij nog aan zichzelf gelijken.

Meester Huyghe was korporaal geweest in het leger; hij was wel geleerd en dat was een geluk, alzo kon hij zijn school oprichten. In die tijd was het bijna de moeite niet waard aan een kind een ambacht te leren, zeiden de ouders; zij waren toch allen voor het kanon, en ook al hadden zij er nog een gekend vóór hun vertrek, zij zouden er bij hun thuiskomst niet meer handig in geweest zijn. Daarbij ${ }^{8}$ komt het misschien, dat de weinig overgebleven soldaten van het eerste keizerrijk bijna allen in armoede gevallen zijn.

Meester Huyghe werd ook niet rijker: wie gewoonlijk zovele stielen uitoefent, heeft er geen enkele goede; ook was het meest uit medelijden, dat de mensen bij hem kwamen. 'Indien ik in uw plaats ware,' had de burgemeester eens gezegd, 'ik zou in het armhuis gaan; gij zijt beiden oud, en voor uw schoon huisraad zoudt gij geen moeite hebben om aanvaard te worden: gij zoudt daar onbezorgd uw leven kunnen eindigen.'

Dat had Meester Huyghe uitermate bedroefd, en als hij het aan Beatrice vertelde, weende zij en zegde: 'wat scheelt het hem, of wij armoede hebben of niet, hebben wij hem niet altijd betaald?', want zij woonden in zijn huisje.

- 'Ja, er weet ons niemand iets te vragen,' sprak Meester Huyghe fier, 'en God zal er in voorzien. Beatrice, zoang ik leef, zult gij in het armhuis niet gaan.'

'Och, neen, zover zijn wij toch nog niet gebracht', zei Beatrice.

Een armhuis is een schone instelling, en in meest alle worden de oude arme lieden goed behandeld en verzorgd; maar voor iemand, die zoals Meester Huyghe aan een eigen haard en aan betere dagen gewoon is, boezemt die gedachte toch afschrik in.

Meester Huyghe zat gewoonlijk des zondags aan zijn laag tafeltje met een hoornen inktpot en een ganzepen uittreksels uit een boek te schrijven. Dat 
waren alle werken over Napoleon, die de veldwachter hem bezorgde, en daaruit schreef hij wat hij onthouden wilde. Als de avond viel, en hij reeds zijn tafeltje dichter bij het venster geschoven had, herlas hij nog eens, wat hij geschreven had, en vergat nooit, onderaan het blad, de datum en zijn handteken te zetten. Hij schreef dat sierlijk, en met grote letteren. 'Huyghens Johan-Antoon,' en maakte er dan allerlei krullen rond. Toen legde hij het blad bij de menigvuldige andere in de schuiflade van zijn kasken, en ging nog eens uit, of schaarde zich met geheel zijn jonge bende aan zijn deur, waar hij dan ook altijd weer aan 't vertellen ging. Beatrice zat er ook aandachtig naar te luisteren, ofschoon zij alles reeds zo dikwijls gehoord had.

Het gebeurde ook - maar dat was zeer zelden, en daarvoor moest hij in bijzonder goede luim zijn - dat hij zijn oude viool uit de kamer haalde, en daarop begon te spelen: hij wist bijna zelf niet, waar hij het geleerd had. Het klonk zoet en een weinig weemoedig in de avondstilte.

Zij bleven er somtijds zitten, tot het geheel laat was en koel werd, en de trage slagen van de dorpsklok hun oor troffen, terwijl nu en dan een vledermuis voorbijfladderde, en de steenzwaluwen zich schaterend rondom de schaliën van de kerktoren verzamelden.

\section{IV}

Zij hadden ook een zoon gehad: maar zelden spraken Meester Huyghe of Beatrice van hem. De mensen in het dorp zeiden niet veel goed van hem: het was een bedorven ${ }^{9}$ kind geweest, een windbui, een echte heer, die op het kantoor van de notaris schreef, als hij nog thuis was; de andere jongelieden hadden nooit veel van hem gehouden. Bij zijn ouders kon hij niet misdoen: Meester Huyghe had met hem iets groots in de zin gehad, en de mensen, die hem gekend hadden, vertelden nog, hoe soms Beatrice hem met haar ogen kon navolgen, over haar halve deur, als hij des zondags uitging, zolang zij hem maar zien kon.

Het was ook een visser en een wildstroper geweest. Hij had de laatste jaren, dat hij in het dorp was, een jachtproces gehad, hetwelk Meester Huyghe veel geld gekost had: het was sedert, dat hij zo verarmd was; want Beatrice had geld gehad, als zij getrouwd was.

$\mathrm{Nu}$ was de zoon sinds lang heen naar Amerika of naar Australië, men wist het niet goed: hij was zo opeens verdwenen. Sommigen zeiden, dat hij onwetend een ongeluk gedaan had, en lieten verstaan, dat hij 's nachts in den donkere een bedelaar had doodgeschoten, en was gevlucht; maar dat was niet waarschijnlijk: men had nooit zulk een bedelaar gevonden. Anderen beweerden, dat hij zich bij zijn patroon aan schriftvervalsing had plichtig gemaakt, en dat deze, uit achting voor de vader, hem had laten ontsnappen; wat de notaris betreft, die gaf daar geen uitlegging over: men wist niet, wat er onder schuilde. 
De mensen spraken er onder elkaar nog somtijds van; maar er was niemand, die het zou gewaagd hebben aan Meester Huyghe te vragen, wat er van Evarist geworden was.

De oude man wist het zelf niet: hij had nooit meer van hem gehoord. De laatste brief, die hij van hem gekregen had, was geschreven een paar uren, vóór hij ingescheept was.

Er kon niet de minste twijfel bestaan: Evarist was sinds vele jaren dood; maar Beatrice zei aan Meester Huyghe, dat men er toch geen zekerheid van had, en dat hij nog weerkomen kon.

\section{V}

Aldus leefden de beide oude lieden voort, met hun hoop en hun vrees; want zonder hoop leeft men niet. Zij hoopten nog altijd, dat Evarist eens weerkeren zou. Zo lang men het zich ontkennen kan, dat men iemand verloren heeft, doet men het: niettegenstaande iedereen de zoon van Meester Huyghe voor dood hield, was hij van Vader en Moeder niet vergeten, en werd hij nog thuis verwacht.

Hun vrees was het armhuis; des te groter was zij, omdat ze die niet bekennen mochten. Het gebeurt zo dikwijls, dat iemand u op een reddingsplank wijst, en dat gij juist dat voor de klip aanziet, die u geheel verbrijzelen moet.

De veldwachter ook, die wel wist, dat Meester Huyghe en zijn vrouw begonnen armoede te hebben, sprak hun eens van in het armhuis te gaan: hij zei hun, dat allen er zo goed verzorgd en zo tevreden waren: de Burgemeester had hem dat alzo opgegeven.

Het is zonderling, er zijn mensen, welke $u$ gaarne een dienst doen, die $\mathrm{u}$ bedroeft, en alzo was de Burgemeester. Hij hield dan ook niet op aan Meester Huyghe een plaats in het armhuis aan te bieden: de oude man moest hem daarvoor dankbaar zijn; want eenieder geraakte er niet in; maar hij werd toch treurig telkenmale men er hem over sprak. Hij gevoelde, dat hij met dat ongeluk bedreigd was, en wilde het toch zolang hij kon verdagen.

Het is dàn eerst, wanneer men een struik poogt uit te rukken, dat men gewaar wordt, hoe vast de wortel staat, en nu ook dat hij het verliezen ging, zag Meester Huyghe, hoe hij aan zijn huisje gehecht was.

Jammer dat Beatrice zo zwak werd: zij was nog enige jaren ouder dan hij, en in de winter altijd ziekelijk. Zij moest voedsel hebben, zei de dokter, en daarom was het misschien ook, dat de Burgemeester er zo op aandrong om hen in het armhuis te nemen. Hij wist, dat Meester Huyghe bijna niets meer won $^{10}$ en de oude vrouw gebrek leed. 'Die mensen willen niet geholpen worden, zei hij aan zijn kinderen; en was hij het nochtans niet, die hun het laatste, dat zij bezaten ontnemen wilde: hun eigen haard, hun stukje land, en hun vertrouwelijkheid? 
Een arme man mag niet bekennen, dat hij een afschrik van het armhuis of van het hospitaal heeft: dat bekende Meester Huyghe ook niet; hij dankte de Burgemeester voor zijn aanbod, maar stelde het nog altijd uit: hij was vastbesloten, dat Beatrice er niet in gaan zou; want zij was ziek, en hij wist het, zij zou ervan sterven.

'Ik heb mijn kasken niet nodig', zegde hij aan de veldwachter, die ging trouwen: 'ik zou het willen verkopen, er is een ingemaakt kasken in mijn huis.' De veldwachter was goed: hij begreep hem, en gaf er hem meer voor, dan het waard was. Hij kwam het 's avonds halen, opdat het niemand zien zou. Het was als een doodkist, die uit het huisje gedragen werd. Beatrice had het meegebracht, als zij getrouwd was.

Meester Huyghe nam zijn pak volgeschreven bladen en legde die in een doos op het schouwbord. ${ }^{11}$ Beatrice sliep: zij was zeer ziek; zij wist het niet, dat haar kasken verkocht was; maar Meester Huyghe moest geld hebben. Aan de deur trok hij de veldwachter bij zijn frak en zegde hem stil: 'maar indien nu eens, wat misschien zou kunnen gebeuren, mijn zoon weerkwam, en wat geld had, gij zoudt mij toch het kasken weer verkopen, nietwaar?'

- 'Ja', zei de veldwachter, en drukte hem de hand.

\section{VI}

Enige weken daarna stierf Beatrice. Meester Huyghe was tevreden in zijn hart, dat hij haar toch tot het laatste toe gehouden had, en dat zij in het hospitaal niet gestorven was. Het scheen hem, dat het een troost moest geweest zijn voor haar, op haar sterfbed al de voorwerpen, waaraan zij gewoon was, rondom haar te zien, het uurwerk te horen, waarvan zij de slag kende, en haar behangsel rondom haar bed te hebben met de druiventrossen en de kinderen, die met de grote hond speelden, welke erop gedrukt waren. Ik heb ze toch kunnen houden, dacht hij. Het was een zegepraal, die de oude soldaat behaald had!

De kinderen uit het dorp kwamen naar Beatrice kijken. Meester Huyghe toonde ze hun, en vroeg, of zij haar nog kenden, en of zij des nachts voor haar niet bang zouden zijn. Thuis vroeg hun hun moeder, of Meester Huyghe niet weende. 'Neen,' zeiden de kinderen.

Hij stond erbij, als zij in de kist gelegd werd, en gaf haar een kruisken: ${ }^{12}$ hij rilde bij die aanraking. Het scheen hem, dat niets zo koud was als dat dode voorhoofd!

Meester Huyghe zal haar niet lang overleven, zei men in het dorp; en nu begon men hem weer van het armhuis te spreken. Hij was daar zodanig aan gewoon, dat het hem zonderling scheen, als iemand hem het woord toestuurde zonder het gesprek daarop te brengen. De notaris is een braaf man, dacht hij: hij heeft mij nog nooit van het armhuis gesproken.

$\mathrm{Nu}$ was hij gans alleen. 
De Burgemeester bleef aan zijn deur staan eens dat hij hem zag komen, en zei hem: 'wel Huyghens, wat schikt ge nu te doen?'

Het is pijnlijk ondervraagd te worden, als men niet weet wat antwoorden, en raad te krijgen, die men niet gaarne volgen zou.

- 'Ik weet het niet,' zei Meester Huyghe, 'ik zal zien.'

'Gij hebt ongelijk, vriend,' gaf de Burgemeester tot antwoord; 'weet ge, wat ge doet? laat mij de wagen uit het armhuis zenden: wij zullen er geheel den boel op laden, en gij zult stillekens achteraan komen. Gij weet toch immers ook wel, dat gij hier zo niet blijven kunt.'

Meester Huyghe stelde het nog uit. De Burgemeester haalde de schouders op en ging heen.

De oude man kwam niet veel meer aan zijn deur, omdat men hem altijd van het armhuis sprak: het was, alsof de mensen er zijn vertrek mee verhaasten wilden. Hadden zij hem daar gerust gelaten in zijn armoede, hij zou hun dankbaar geweest zijn, dat zij hem over zijn bekommernissen niet spraken. Alzo is het menselijk hart: iedereen wist, dat men Meester Huyghe bedroeven zou, had men hem van zijn zoon of van Beatrice gesproken; maar men dacht er niet eens aan, dat men van het overige ook zwijgen moest, en hem niet mocht vragen, wat hij nu ging doen; want hij wist het niet.

Helaas! hij wachtte op zijn zoon!

\section{VII}

De meimaand kwam, en Meester Huyghe kon zijn pacht niet betalen: dat kwelde hem. Hij trok recht naar de Burgemeester en zegde hem, dat hij bereid was in het armhuis te gaan. De Burgemeester zou hem nooit naar die pacht gevraagd hebben; maar Meester Huyghe wilde geen aalmoes aannemen. Zijn huisraad was veel meer waard dan hij aan de Burgemeester schuldig was; ook zei hij hem, dat het Armbestuur hem ongetwijfeld zou betalen, aangezien men alles, wat hem overbleef, mee zou nemen. Hij was er fier op geen schuld na te laten, en alles in orde te hebben, vóór hij naar het armhuis ging. En nu dacht hij: 'wat geeft het mij ook, ik heb er Beatrice toch uit gehouden!'

- 'Wel zeker', sprak de Burgemeester, en dwong hem neer te zitten, om wat te praten; 'gij zult er zo wel zijn; gij hadt dit reeds lang moeten doen; ik zal ervoor zorgen, dat gij een kamerken alleen hebt, indien het zijn kan, waar gij uw prenten kunt hangen,' zei hij met goedheid, 'en uw viool zult gij ook behouden, en er zal u niemand een stro in uwen weg leggen, of ik zou het weten.'

Hij dwong zijn oude meester een glas wijn met hem te drinken; maar het wilde Meester Huyghe door de keel niet, en als hij heenging om al zijn klein huisraad gereed te maken, bleven zijn woorden haperen, en hij had moeite om de Burgemeester voor zijn goedheid te danken; deze drukte hem met 
genegenheid de hand en zei: 'Meester Huyghe, het zal er beter zijn dan ge denkt.'

De veldwachter laadde het huisraad op de wagen en liet die voorop rijden: hij kwam stillekens achteraan met Meester Huyghe; want hij had het wreed gevonden die oude man geheel alleen te laten gaan.

'Zie eens Meester Huyghe, die naar het armhuis trekt!' zeiden de lieden, en zij riepen hem toe: 'goede reis, Meester Huyghe! gij moet ons komen bezoeken,' zeiden zijn geburen; 'ik hoop, dat gij het er goed stellen zult!'

Meester Huyghe nam de hoed af: de wind speelde om zijn lang, versleten grijs haar, terwijl hij de mensen rechts en links dankte voor hun vriendelijke woorden. 'Ik wist niet, dat ze mij zo gaarne zagen,' sprak hij tot de veldwachter.

Hij scheen er een reden in gemaakt te hebben, en koutte zonder een zucht, of zonder een traan in het oog. Hij sprak ook van Beatrice, en als van iemand, die nog leeft.

'Het is als naar de gevangenis gaan,' zei een knaap aan zijn moeder, 'alzo met de veldwachter.'

Zij moesten over het kerkhof: dat was de kortste weg, en Meester Huyghe zweeg, en keek naar de grond: het was, alsof hij moeite had om voort te gaan. De veldwachter vertraagde zijn stap: die oude lieden kunnen zo haastig niet meer op, dacht hij. Meester Huyghe vreesde misschien, dat de veldwachter zijn gedachten mocht geraden hebben; want hij wees met zijn stok in het hoge gras, als om zich te verontschuldigen, dat hij daarin keek, en zegde als onverschillig: 'het is zonderling, dat er op de kerkhoven altijd zoveel maluwbloemen ${ }^{13}$ groeien.'

- 'Ja,' zegde de veldwachter, 'mijn jongste zuster moest er ook gaan zoeken voor haar zere ogen; maar zij had er iets tegen om er op het kerkhof te halen: zij is er op de Molenberg gaan plukken.'

Een gevoelige ziel is als bestolen, wanneer iemand haar gewaarwordingen bespiedt, en wendt alle moeite aan om haar indrukken voor vreemden te verbergen.

'En nu verhuis ik niet meer,' sprak Meester Huyghe bijna glimlachend, als zij aan de poort van het armhuis kwamen; 'ik heb genoeg gereisd, en ga nu hier blijven, tot ik voorgoed verhuizen moet; en dat zal ik dan ook nog zo lang uitstellen, als ik maar kan.'

Het scheen hem toch somber en treurig de eerste avond, die hij in het armhuis overbracht, ${ }^{14}$ nadat de zware poort achter hem toegesloten was.

\section{VIII}

In het armhuis kreeg iedereen aldra Meester Huyghe lief: hij was niet lastig en zo behulpzaam, zei men. Daar zat hij nu ook op het brede hof in de zon aan de naakte muur, met een groep net geklede, kreupele bedelaars rondom 
zich, en deze luisterden naar hem zoals vroeger zijn oude scholieren. Hij vond er, gelijk eertijds, hetzelfde vermaak niet meer in aldus te vertellen; maar hij vreesde misnoegd te schijnen, had hij er zonder spreken moeten zitten, en die brave oude lieden hielden niet op van vragen.

Het is een der zoetste vreugden van het tehuis, te mogen zwijgen, als men geen lust tot spreken heeft. Zo had hij dikwijls een gehele namiddag met Beatrice zitten werken, zonder dat een van beiden een enkel woord sprak, somtijds tot het bij de avond werd, en Beatrice zei: 'ik zou wel het vuur ontsteken,' en zij ging het avondmaal gereed maken, zonder dat hij antwoord gaf: nu mocht hij dat niet meer doen.

Hij zat bijna altijd met de stok in de hand, gelijk een reiziger, die hier enkel een ogenblik zit te rusten. Vroeger nam hij die alleenlijk, wanneer hij uitging; thans legde hij hem bijna niet meer uit de hand. Een voorwerp, al is het maar een uurwerk of een gaanstok, is een gezelschap voor hem, die geheel alleen staat in de wereld.

Als hij des zondags naar de mis kwam, vroegen hem zijn oude geburen, hoe hij het stelde, en of hij tevreden was. Hij zegde: 'ja; zij zijn goed; - ik ben er wel verzorgd; - er ontbreekt mij niets; neen, neen, ik heb niet te klagen,' zei hij, als iemand, die vreest, dat zijn treurigheid voor ondankbaarheid zou kunnen doorgaan.

Hij meende, de arme oude man, dat hij het recht niet had zich ongelukkig te gevoelen, hij die geheel alleen op aarde was, wanneer er nog mensen waren, die hem vriendelijk aanspraken, en er hem een schuilplaats in zijn oude dagen werd aangeboden.

Hij ging niet veel meer uit. 'De moed ontbreekt hem,' zeiden degenen, die er klaar in zagen; het was waar: hij was niet ziek, en nochtans, het was dodelijk hetgeen hij had: hij verlangde naar zijn huisje, naar zijn zoon en naar Beatrice!

Het is droef naar het onmogelijke te verlangen.

Beatrice was heen, en zijn huisje was verhuurd: dat wist hij; maar Evarist! Dat wist hij niet, of die niet nog terugkeren kon: hij klampte zich met wanhoop aan die gedachte vast.

Hij zat alleen aan de buitenmuur op het hof. Enige arme kinderen speelden voor zijn voeten en gaven geen acht op hem. Hij zat en droomde; hij dacht aan Evarist, en indien die eens kwam, hoe bedroefd hij wezen zou, Vader in het armhuis te vinden, en hoe hij het hem zeggen zou, dat Moeder dood was. Hij wist het niet; maar een traan viel van zijn wimpers op de beide magere handen, die hij aan zijn stok hield, en weer een andere traan, en de oude man verschrikte, toen hij opeens de Burgemeester voor zich zag staan, die hem vroeg, hoe het ging, en of men hier dan niet goed was voor hem?

'Ja, mijnheer de Burgemeester, ja, zij zijn allen goed, - allen.... maar een oude boom wil niet verplant zijn,' zei hij. 


\section{IX}

Het was een warme herfstdag: de droge bladeren kraakten onder de voeten in de dreef, en de zon scheen geel en flauw in de toppen der bomen. De doodsklok luidde, de doodsklok voor een arme mens. 'Het zal zeker iemand uit het armhuis zijn,' zei men.

Het was Meester Huyghe.

Als iemand van den arme begraven wordt, duurt het niet lang: de klok houdt gauw op, het gezang evenzo, en men komt, met de verschoten vanen en het koperen kruis, het lijk enkel tot aan het kerkhekken tegen.

Meester Huyghe werd gedragen door de Napoleonisten. Er waren er nauwelijks nog genoeg om hun trommel, hun vaandel en hun oude wapenbroeder te dragen. De enen waren groot, de anderen klein: de gekromde oude lieden hadden moeite om de lange kist van Meester Huyghe van de grond te heffen; de kerkbaljuw ${ }^{15}$ moest hun hierin ter hulp komen.

Gewoonlijk ziet men geen zulke oude lieden iemand naar het graf dragen: dat scheen ook boven hun macht. Zij hadden een rouwfloers aan hun vaandel en over hun trommel, en elk een rouwfloers aan de arm, of liever een stukje ros geworden zwarte tule, dat ervoor diende.

Zij gingen zwijgend heen na de begrafenis.

Zij staan nog hier en daar, die soldaten van het grote leger, die het kanon gemist heeft, gelijk de vergeten koornaartjes op een stoppelveld. Zij zijn teruggekeerd, elk op zijn geboortedorp, waar zij nu rondom de kerktoren komen slapen, en allen, allen gaan heen zonder een klacht, of zonder een verwijt aan hem te doen, die hen voor zijn ijdele roem uit huis en erve gedreven heeft.

Wat zou hij zeggen, de grote veldheer, indien hij nu het grote leger zag?

En Meester Huyghe rust daar nu ook: hij is thuis, bij Evarist en bij Beatrice. 


\section{Po en Paoletto}

Giuseppe Rosselli heette hij; maar in het dorp noemde men hem Djosep de glazenmaker. Hij was schilder en glazenmaker. Hij was Zwitser van geboorte, van het kanton Ticino, uit het district Giubiasco, maar woonde reeds sedert vele jaren hier te Meerkerke, zodat hij door niemand meer als vreemdeling werd beschouwd.

Hij keerde nog alle twee, of ten minste alle drie jaren naar zijn vaderland terug, en zou er toch gaarne zijn leven eindigen, zegde hij; want bij bleef toch zijn geboortedorp als zijn tehuis aanzien, en hoopte altijd er eens voorgoed terug te keren. Er waren mensen, die zegden, dat hij er getrouwd was. Pietro Carmine, die zich als glazenmaker te Eeklo had geplaatst, beweerde, dat hij vrouw en kind had, doch zulks had verzwegen, omdat hij wel wist, dat een getrouwd man bij de jongelieden niet veel aantrek vindt; echter, daar Carmine als de grootste leugenaar van geheel de streek bekend stond, werd maar half geloofd, wat hij zegde.

Giuseppe was gezellig en gespraakzaam; nochtans als iemand hem nopens Zwitserland ondervroeg, gaf hij weinig uitlegging, en scheen liever van iets anders te spreken. Hij zegde, dat het er warmer is dan hier, en dat het een nogal verre reis is, ook dat de mensen er wat bruiner zien: daarmee wist men niet veel. Waren er die hem vroegen, of hij nog vele naastbestaanden had, zo antwoordde hij onveranderlijk: 'Ze zijn ze er eigenlijk al enigen dood, en ze zijn ze er ook nog wel in 't leven.'

Hij was klein van gestalte, maar breedgeschouderd en van sterke lichaamsbouw. Zijn gelaat was bruin; zijn ogen levendig, en zijn grote neus naar de mond gebogen. Hij mocht nu wel in de veertig zijn. Hij won veel geld, leefde als een deftig burger, en werd alom geacht en bemind om zijn goed gedrag en zijn zachtaardigheid.

Zijn knecht Conciper was nog kleiner dan hij, nog bruiner van aanzicht, ${ }^{1}$ nog zwarter van haar, en zijn dichte wenkbrauwen waren dooreengegroeid. Beide mannen waren nagenoeg van dezelfde ouderdom. Conciper was ook glazenmaker van zijn ambacht; maar gewoonlijk ging Giuseppe te lande, met de $\mathrm{kas}^{2}$ op de rug, met een grote bal stopverf erop, en in de rechterhand de brede platte houten meter; alzo trok hij vrolijk en welgemoed de morsige landwegen in. Conciper deed het huiswerk en was kok: hij spoelde de salade, en sneed de ajuin, en bakte het brood. Gedurende de tijd, die hij over had, verguldde hij lijsten voor spiegels en prenten, en schilderde hij pleisteren beeldekens en kapellekens ${ }^{3}$ voor de boerinnen, die ze dan 's zondagsmorgens kwamen halen. 
Giuseppe bleef dikwijls des middags uit, wanneer hij verre ging; dan gaf Conciper hem boterhammen en een stuk gedroogde worst mee om dat onderweg te eten; maar Giuseppe kon geen bedelaar ontmoeten, of hij gaf hem de helft van zijn karig noenmaal, terwijl hij binnensmonds bromde: 'Katerkeu! ze heeft ze nog meer honger dan ik.' Ook wanneer hij ergens een schone appel gekregen had, bleef die niet lang in zijn zak: zodra hem er een kind met een raap of een wortel in de hand tegenkwam, begon Giuseppe te glimlachen, haalde de appel uit, en hield hem die voor de ogen. Hoe gauw had het kind die appel vast! Had hij er twee, zo spaarde hij er een voor Conciper.

Er zijn toch mensen, wier hart met ranken groeit, die zich aan alles klissen, wat hen omringt. De goede Zwitser kleefde zich aan alles, wat hij zag: hij beminde het dorp, zijn arbeid, de wegen, langswaar hij gewoon was te gaan; hij beminde het oude huis, dat hij bewoonde, en vooral Conciper, zijn trouwe gezel en landgenoot, zijn beste vriend.

Wanneer hij des avonds thuiskwam, hielp deze hem de riemen van de kas losmaken, trok zijn schoenen uit, bracht hem zijn sloffen, en diende het avondmaal op. Hoe lustig zaten dan beiden voor de dampende schotel en het fris, grof linnen ammelaken ${ }^{4}$ in hun Italiaans dialect te praten! het waren als de zwaluwen. Och! het was hier zo huiselijk en goed, en het scheen zonderling, dat Giuseppe nog naar een ander tehuis verlangde!

$\mathrm{Na}$ het eten las hij de gazet; want hij kon Vlaams lezen; deze had hij gezamenlijk met zijn gebuur Baas Van Hecke. Zij betaalden elk de helft van het abonnement. Giuseppe kreeg ze eerst: des anderdaags zond Baas Van Hecke die halen en mocht ze behouden.

\section{II}

Het huis, dat Giuseppe bewoonde, was eigenlijk veel te groot voor hem; maar het was het enige, dat ledig stond, wanneer hij in het dorp gekomen was, en nu dacht hij aan geen verhuizen meer: hij scheen er vastgegroeid.

Het was een ouderwetse woning, met de gevel naar de straat gekeerd, en in het bezetsel van de muur bevond zich een schild, Christus verbeeldende, die onder het kruishout valt. Op de achterzijde van het huis verhief zich een hoge schoorsteen, waarop een zonnewijzer getekend stond. Het kwam nog voort van de oude abdij, zegde men, en was, ten tijde dat de kloosters afgeschaft werden, ${ }^{5}$ als nationaal goed verkocht geworden.

De winkel was een grote, vierkante plaats, met een venster langs elke kant van de deur. Voor het ene stond een brede tafel, waarop het glas gesneden werd, en op de vensterboord bevonden zich enige cactussen, een oleander en een serpentine, die met grote zorg door Conciper werden gekweekt. Op de houten boordels ${ }^{6}$ zag men verfpotten, borstels, en penselen, en langs de andere kant stonden kisten glas, de loodmolen en enige withouten kaskens 
en bakskens, ${ }^{7}$ die voor de winkeliers moesten geschilderd worden. Boven de deur, die naar de keuken leidde, hing een oude, duistere schilderij in olieverf, Sinte-Cecilia voorstellende, met de handen aan de harp en de ogen ten hemel geslagen.

De keuken was bijna zo ruim als de winkel. Er stond een overgrote glazenkas in met oude schotels van gleiswerk, porceleinen teljoren ${ }^{8}$ en kopjes. Aan de muur hing een uurwerk van een zeldzaam maaksel in een kort zwart en verguld kasken, dat Giuseppe, evenals al zijn andere meubelen, eens in een openbare verkoping had gekocht. De tafel was vierkant, met afgeronde hoeken en kromgesneden pikkels, die van onder een leeuwenvoet vormden. Er was een gat in, dat met stopverf was toegestopt.

De ingang van de kelder was met een trapval, en om op de zolder te geraken moest men insgelijks een val in het plafond openleggen. Dat was wel gevaarlijk; maar zij waren eraan gewoon.

\section{III}

Baas Van Hecke was eigenaar van het huis van Djosep de glazenmaker. Het was een stokoud man, die met niets begonnen was, zoals men zegt; en, als hij trouwde, rondging met een pak garen, lint, saaiette, ${ }^{9}$ knopen, naalden en spelden. Wat later had hij een ezel en een kar, waarin zijn goed lag: stukken ongebleekt katoen, flanelle, zakdoeken, voeringgoed en wollen sarges. ${ }^{10}$ Daarna had hij een winkel gehouden en was rijk geworden in zijn stand. Thans leefde hij sedert enige jaren van zijn inkomen, doch had weinig aan zijn levenswijze veranderd. Zijn vrouw was bijna zo oud als hij. Zij zagen geen mensen en leefden zeer afgezonderd. Hun huis was als een graf. Een der keukenvensters had ook uitzicht op het kerkhof. Dat was maar treurig voor Bazin Van Hecke, die er altijd aan te naaien zat, voor zoveel haar flauwe ogen haar zulks nog toelieten.

Sinds enige weken hadden zij een klein meisje in huis genomen om de ouders te ontlasten: het dochtertje van hun neef, een arm, doofstom kind van omtrent twaalf jaar.

Haar ouders waren zeeldraaiers en woonden te Smoregem wel anderhalf uur vandaar.

'Ach!' zei Bazin Van Hecke tot Giuseppe; 'het doet mij goed, als ik die kleine beschouw, te weten, dat ze nu lederen schoentjes heeft in plaats van haar holleblokken, dat ze nu geen roggen brood meer zal moeten eten gelijk thuis. Wanneer ik denk, dat zij maar twee hemdjes had, toen zij hier aankwam, en haar nu bij ons niets ontbreekt!'

Alzo sprak de oude vrouw in haar blinde goedheid van haar weldaden.

Het jonge meisje heette Pauline, en kon een enkele klank uitspreken, waarmee zij haar naam beduidde: 'Po,' kon zij verstaanbaar zeggen, en dat herhaalde zij van tijd tot tijd, gelijk de vogeltjes, die maar één gepiep ken- 
nen, en het altijd laten horen. Zij zag er bijzonder ernstig uit voor een kind van haar jaren; doch haar wezenstrekken waren zeer fijn en regelmatig, en haar blond haar krulde van achter uit haar mutsje in de nek.

$\mathrm{Zij}$ verveelde zich bovenmate bij haar oude oom en haar oude tante, die haar wel liefhadden, maar toch niet dachten, dat zulk een kind leren en spelen moet, en zijn tijd ergens aan besteden. Zij kon naar school niet gaan, aangezien zij niet spreken kon, en haar tante was veel te oud om haar enig handwerk te leren.

De andere meisjes wilden met haar niet spelen, omdat zij haar niet verstonden, en zij niet hoorde. Dan zat Po bij haar tante aan het kerkhofvenster, en dacht aan thuis, aan haar pop, die zij zo gaarne zag, en die bij haar sliep, maar die zij nu aan een jonger zustertje had moeten afstaan, - aan haar broerkens, die draaiden, als zij in de koord danste, en aan broer, die brij roerde, en voor elk een klontje boter op de teljoor lei, wanneer het feestdag was.

De arme Po had de schrikkelijkste aller kinderziekten, het heimwee; want vooral kinderen verre van huis zijn onderhevig aan die kwaal. Ja, eens dat zij het niet meer uithouden kon, was zij ontsnapt, en naar huis gelopen, maar als een deserteur weer opgevangen en teruggebracht.

Alle avonden maakte zij het teken van het heilige kruis, vouwde haar handjes, en zette zich een ogenblik op de knieën, voordat zij slapen ging, omdat Moeder het haar had geleerd; doch zij wist niet, waarom zij het deed, noch wat betekenis het had.

\section{IV}

Baas Van Hecke had geen hof: hij had maar een smal koerken, dat met een poortje, hetwelk nooit gesloten werd, op dat van Djosep de glazenmaker kwam. Doch hij bezat integendeel op het uiteinde van het dorp, daar waar de huizen ophouden, een schoon eigendom, dat men het Boomgaardje noemde; maar het was wel eigenlijk een grote, lange boomgaard, met een dreef in 't midden, waarlangs kerselaars, kriekelaars, en notelaars stonden. Een gedeelte ervan diende tot moeshof, en op het einde der dreef had eertijds een huisje gestaan, dat lang onbewoonbaar geweest, en nu ingestort was, en in puin lag. Onder de schoolkinderen bestond het geloof, dat het een verwenst huisje was, en de donder het had vernield.

De oude Baas Van Hecke dacht er niet aan het herop te bouwen: het was een hoop steen, waaruit hier en daar netels, scheerling en goudwortel ${ }^{11}$ schoten. Men zag nog de drempel, die tot rustbank dienen kon; een brok van de muur stond nog recht, met witgekalkte, groenachtig geworden binnenwand, en een deel der berookte schouw, die maar half was ingestort, stak boven alles uit: hier huisden de hagedisjes en de egels.

Po moest er somtijds met haar mand konijneneten gaan zoeken, en dat 
deed zij gaarne. Zij bracht haar koord mede en danste, danste de lange dreef op en neer, tot zij moede was en op de drempel van het verwoeste huisje ging zitten. Zij moest alleen spelen; want de andere meisjes wilden niet draaien en haar niet laten mededansen.

Ach! hoe gaarne had Po met de schoolkinderen gespeeld! Zij sloop soms zachtjes naar de zolder, waar een netzak met droge noten hing, keek eens om, of 't niemand zag, en stak haar zakken vol.

Eilaas, de stem van het geweten wordt niet duidelijk vernomen door zulk een doofstom kind, aan hetwelk men ze nooit kan doen horen! $\mathrm{Zij}$ wist wel, dat men het haar beletten zou, had men gezien wat ze deed; maar zij dacht toch geenszins, dat het een misdaad was. Dan kwam zij zegepralend bij de anderen, deelde haar noten uit, en mocht mededansen. Doch dit gebeurde maar zelden: zij werd vermeden en verstoten, en moest alleen in het Boomgaardje gaan zitten. Wat deed zij daar in die lange lentedagen? Zij kwelde en tergde de diertjes; zij achtervolgde met een zweepje de puidjes ${ }^{12}$ en hagedisjes, of zocht het kruidje duivelsbeet, waaruit een zo schone witte melk vloeit, en streek dat brandig sap over haar eigen gelaat, hetgeen voor gevolg had, dat zij met een paar ontstoken oogschelen en gezwollen lippen naar huis moest komen. En dan lachte zij om hetgeen zij gedaan had.

Zij was onmeedogend geworden, omdat zij bij de kinderen slechts boosheid en kwaadwilligheid had ontmoet.

Zij was het, die nu alle dagen bij Giuseppe om de gazet kwam. Zij bleef soms lang bij Conciper staan, wanneer hij beeldekens schilderde, en deze gaf haar een stukje stopverf, en toonde haar, hoe zij er potjes en pannetjes uit moest kneden, en die in de zon laten drogen.

Conciper bevond zich sedert enige weken alleen te huis: Giuseppe was naar Zwitserland.

\section{V}

Ditmaal kwam Giuseppe niet alleen terug; hij had een kleine jongen van twaalf of veertien jaar meegebracht, Paoletto, die bij hem zijn ambacht moest leren, zegde hij. De knaap zag er bijzonder wakker en schrander uit. Zijn zwart haar was op zijn voorhoofd kort gesneden, maar hing van achter tot in zijn hals, en in zijn donkere ogen lag die glans, die zuidertint, welke $\mathrm{u}$ als een zonnestraal tegenlacht. Hij droeg het rond hoedje, het kort vestje en de sterke schoenen der bergkinderen. De andere jongens lachten hem uit, als hij met hen wilde spelen; want er was niemand, die zijn taal verstaan kon.

Hij stond in de winkel bij Conciper; de kleine Po kwam de gazet halen, en bezag hem nieuwsgierig van het hoofd tot de voeten. Paoletto zag ook het lief klein meisje aan, en begon te glimlachen. 'Po,' zegde zij; want dat was 
alles wat zij zeggen kon. Giuseppe wilde haar doen binnenkomen; maar zij deed hem teken, dat zij naar het Boomgaardje om konijneneten moest gaan. Hij haalde de gazet uit de keuken, en zei aan Paoletto, die hier geen speelmakkers vond: 'ga mee, en help haar de mand dragen.' Paoletto nam haar bij de hand, en beide kinderen trokken op.

Po toonde hem wat konijneneten en wat onkruid is, en in een zeer korte tijd had de knaap met zijn zakmes een halve mand melkdistels, en ribbe, ${ }^{13} \mathrm{en}$ wilde-vlierstruiken gesneden, en Po, die langs een andere kant bezig was, kwam ook aldra met haar voorschoot opgepropt. Zij had zo vlijtig gewerkt, dat zij ervan bloosde, en onderzocht de inhoud van de korf zorgvuldig, aleer zij er haar voorschoot in ledigde, om te zien of de kleine vreemdeling er geen onkruid had bijgevoegd.

Och, wat genoegen was het zo met tweeën om het zeerst ${ }^{14}$ te arbeiden!

Als de korf vol was, leidde zij Paoletto naar het ingestorte huisje, en zij zetten zich naast elkaar op de drempel neer. Wat jammer, dat zij niet tezamen praten konden! Zij zagen elkander van tijd tot tijd aan, en glimlachten. 'Po,' zegde het meisje nu en dan, 'Po,' want het scheen een genot voor haar te zijn die klank te doen horen, en zij was er fier op te tonen, dat zij spreken kon. Arm vogeltje, dat zijn gepiep herhaalde!

Het was zomer: de krieken waren rijp, en in een oogwenk zat Paoletto op een boom. Po moest de krieken, die hij plukte, in haar voorschoot opvangen; want hij had niets, waarin hij ze leggen kon.

Dan zetten zij zich weer op de stenen drempel om ze op te eten. De jonge Zwitser vond er behagen in het klein, mooi meisje aan te zien: het was iets nieuws voor hem, dat fris gezichtje met blond haar en blauwe ogen. Hij wees met de vinger op zijn borst, dan naar haar, nam haar hand, en deed alsof hij een ring aan haar vinger stak. Let op, Paoletto! Po, aan wie men niets kan doen verstaan, Po zal het begrijpen, dat gij haar een huwelijksbelofte doet, en het nooit meer vergeten!

Hij wees haar, dat zij het huisje zouden opbouwen en er tezamen komen wonen, en de kleine Po klapte in de handjes van vreugd. Zij namen de mand op, elk bij een oor, en kwamen het dorp in, en droegen hun fris, geurig groen in de konijnenstal van Baas Van Hecke.

Sinds die dag kwam Po dikwijls Paoletto halen om met haar naar het Boomgaardje te gaan, en het duurde niet lang, of beide kinderen hadden een taal uitgevonden, die hun eigen was, en konden aan elkaar door tekens alles doen verstaan, wat zij wilden. Het gebeurde ook, dat zij veel verder gingen dan het Boomgaardje, en met een overgrote tuil blauwe koornbloemen naar huis kwamen: deze prijkte dan dagen en dagen voor het venster van Djosep de glazenmaker. 
De kleine Po was zo somber niet meer als voorheen: er scheen een zachtere stroom door haar jong hartje te vloeien sedert zij een speelgenoot gevonden had. Zij voelde geen de minste lust meer om diertjes op te zoeken en hun kwaad te doen. Zij zat niet meer aan het keukenvenster met hangend hoofdje, zoals in de eerste tijd dat zij hier woonde, onverschillig en roerloos, terwijl haar tante het huiswerk verrichtte. Zij was van haar landziekte genezen, en dacht bijna aan haar thuis niet meer. Wanneer nu Baas Van Hecke zijn gazet te lezen zat, of met de bril op de neus en het nieuwsblad in de hand in slaap was gevallen, en de oude vrouw opstond om koffie te malen, deed het meisje haar teken te blijven zitten; zij haalde zelf schavelingen ${ }^{15}$ en boskolen, pompte water in de theeketel, zette kopjes, en boter en brood op tafel, en gedroeg zich als een kleine huisvrouw. 'Is het reeds vier?' geeuwde dan haar oom opziende, en Tante zei: 'Ik weet niet, hoe het komt; maar Po is op een enkele zomer gans omgekeerd: zij begint mij waarlijk van veel nut te zijn, en wordt zo vlug en behendig.'

Baas Van Hecke bemerkte ook de verandering. $\mathrm{Zij}$ hielp hem de droge erwten, die voor plantgoed moesten dienen, van de verdorde struiken rukken, en stak die met een stopnaald en een twijndraad aan lange resems, die de oude man dan op zolder aan de balken hing.

Ach! Po dacht daarbij aan het eenzaam, verwoest huisje, waar zij met Paoletto zou gaan wonen! Paoletto was voor haar als de dageraad, die alles ophelderde en verlevendigde.

Het was september geworden, het was Meerkerke-kermis, en de kramen stonden op de kleine plaats van het dorp, de kramen met haar grauwe linnen kap en haar katoenen voorhangsel van witte en rode ruiten, met al de bergen amandels, Spaanse noten, lekkerkoek ${ }^{16}$ en karamellen!

De morgenzon scheen zo heerlijk; de kinderen kwamen al vroeg de lekkernij en het speelgoed bezichtigen. Po stond voor een hoop loden kruiskens, ringetjes, kandelaarkens en soldaatjes. Opeens zag zij Paoletto naast haar: het ernstig gezichtje klaarde op.

Hij haalde zijn portemonnee uit en deed haar teken iets te kiezen: hij wilde haar een geschenk geven. Po bedacht zich een ogenblik, dan zocht zij naar een loden ringetje, en gaf het aan Paoletto, die het betaalde, en om te zien, of het haar paste, nam hij haar hand, en stak het aan haar vinger. Voor de jonge Zwitser was het wellicht enkel kinderspel; maar voor het stom meisje was het de vernieuwing der belofte, die hij haar aan het verwenst huisje had gedaan. Zij liep naar huis; zij toonde wat zij gekregen had aan Oom en Tante, en de oude lieden waren verwonderd het kind zo uitgelaten verheugd te zien over zulk een kleinigheid. 


\section{VII}

Paoletto scheen het hier ten volle gewoon. Zijn vreemd kostuum was half versleten en hem ontgroeid, en nu was hij gekleed juist als andere kinderen; maar zijn uitheemse wezenstrekken en gebaren deden hem door alle vreemdelingen, die hem zagen, opmerken. Zij vroegen, van wat streek die jongen kwam, en wie hij was. Ja, wie was Paoletto? Giuseppe zegde het niet, en geen mens, die ernaar vragen dorst. Spraken zij Conciper ervan, zo haalde deze de schouders op, en zegde, dat hij het niet wist, overigens dat hij Giuseppe nooit in zijn vaderland had gekend, en nog naar Zwitserland niet was geweest, sinds hij in Vlaanderen woonde.

Ofschoon zo terughoudend, wanneer het hun land gold, waren de drie Zwitsers verre van mensenschuw te zijn. Zij waren leden van al de maatschappijen: van de Bolders, ${ }^{17}$ de Boogschutters of Sinte-Sebastiaan, en van de muziek Sinte-Cecilia. Conciper speelde de klarinet en Paoletto de fluit. Giuseppe, die geen noot muziek kende, was echter ook werkend lid: hij was vaandrig, en men was het eens in het dorp om te zeggen, dat het aan niemand zo wel afging als aan hem. Paoletto was al vuur en leven, en zo gans verschillend van onze Vlaamse jongens. Wanneer hij, na een afwezigheid van enige uren, naar huis keerde, en Giuseppe in zijn zondagspak aan de deur zag staan, kwam hij op hem toegelopen, deed een sprong, sloeg de armen om zijn hals, krulde beide benen rondom hem, en terwijl Giuseppe hem losmaakte, riep hij uit: 'O, Beppo, Beppo!' alsof hij zeggen wilde: 'O, het leven is toch louter genot en genoegen!'

Zij schenen alle drie onafscheidbaar: zij sliepen in dezelfde kamer. Deze was even groot als de andere plaatsen van het huis; men moest twee treden op om erin te gaan; zij was zeer laag van zoldering, roodgevloerd en had een groot venster zoals dat van een kerk, waarvan de groenachtige ruitjes in lood waren gevat. Men zegde ook, dat dit de kapel der paters was geweest. Er stonden drie kreupele stoelen in hun kamer en een ouderwetse, schoon geverniste klederkas; ${ }^{18}$ aan de wand hing een lange mantelstok voor hun dagelijkse klederen. Giuseppe en Paoletto sliepen in het bed langs de rechter kant, een bed met een tombeau, zoals men dat te lande noemt, dat wil zeggen met een latwerk erover, waarop een gordijn van blauw- en witgeruit linnen gespannen is. Conciper sliep op een ezel ${ }^{19}$ langs de andere kant; maar het gebeurde wel, dat zij alle drie, nadat ze reeds lang te bed waren, nog lagen te praten en te lachen, alsof de slaap nooit komen moest. Dit was echter de ware manier niet voor Paoletto om Vlaams te leren, bemerkte Giuseppe; want hij was bijna nooit met andere lieden dan met hun tweeën, die Italiaans spraken, en met Po die hoegenaamd niet sprak.

Conciper ried hem aan, de knaap geheel de winter naar school te laten gaan, en hem enkel met de volgende lente te beginnen zijn ambacht te leren. Het voorstel van Conciper werd goed gevonden en uitgevoerd. 


\section{VIII}

Wanneer de schoolmeester hem vroeg, hoe hij heette, antwoordde de knaap zonder aarzelen: 'Paoletto Gaettani.' Dat was zonderling! Wist hij dan zijn eigen naam niet? Op het register der bevolking had men hem Paolo Rosselli aangegeven.

De kleine Zwitser was nu noodzakelijk in dagelijkse aanraking met andere jongens van zijn jaren, en begon hun taal te spreken en hun spelen te kennen. Po kwam alle dagen omtrent het uur dat hij van school keerde; maar het was winter: zij konden naar het Boomgaardje niet meer gaan, dat ontbladerd was en met sneeuw bedekt, en er akelig uitzag. Ook gebeurde het wel, dat Paoletto niet rechtstreeks naar huis kwam, en bij de jongens op de plaats bleef spelen, die sneeuwballen naar elkaar wierpen, of onder geroep en gejuich een grote sneeuwen man maakten.

De kleine Po zat toen te wachten naar haar speelmakker, die niet terugkeerde. Ja, zij wachtte nu wel dikwijls tevergeefs; want Paoletto had ook leren schaatsenrijden, en bleef liever bij de schooljongens op het ijs dan met het stomme meisje te spelen. Hoe verlangde Po, dat het weer zou lente zijn, en hij van school zou mogen thuisblijven! Maar als het voorjaar kwam, moest hij beginnen zijn ambacht te leren, en met Giuseppe uitgaan: dit maakte, dat hij maar zelden meer maar het Boomgaardje ging.

$\mathrm{Nu}$ was het volop zomer, een hele, dorre zomer zonder regen en zonder koele nachten. Er ontstond een vervaarlijk onweer, vergezeld van een alles vernielende hagelbui.

Giuseppe werd op het kasteel van Meerkerke, of liever van Mere, zoals men bij verkorting zegde, ontboden om te zien, wat schade de storm in de glashuizen ${ }^{20}$ had aangericht. Hij kwam aangestapt met zijn wijde broek, zijn rond vest, en de kas op de rug. De Baron van Mere stond hem aan zijn ijzeren hekken af te wachten, en leidde hem rond. Het was een oud jonkman van in de vijftig jaren, die zich uit liefhebberij veel op de landbouw en het bloemkweken toelegde, en er tevens veel geld mee won. Hij had een paar jaren geleden een model-hofstede laten bouwen, waarvan er veel gesproken werd. Hij was zeer gemeenzaam, en sprak iedereen aan, en geloofde aan minderen alle onbescheiden vragen te mogen doen, en veroorloofde zich ook de buitenlieden met hun bijnaam te noemen.

'Waarom is uw kleine jongen niet meegekomen?' vroeg hij; want hij ook had van Paoletto gehoord.

Giuseppe zegde, dat hij hem nog van geen nut kon zijn, en thuis bij Conciper moest leren schilderen.

'Ik ben verwonderd, dat ge niet trouwt,' zei de Baron, 'ge zijt ook van de jongsten niet meer, en het begint tijd te worden naar een vrouw om te zien, als gij in uw oude dagen wilt verzorgd worden en niet verlaten zijn.'

Giuseppe had hem juist hetzelfde kunnen zeggen; doch hij deed het niet. 
'Meneer de Bron, ze ben ze 'k ik een man, die nooit zal trouwen,' antwoordde hij.

- 'En waarom niet, als gij het niet reeds zijt?' sprak de Baron schalks glimlachend?

'Meneer de Bron, ze zal ze 'k ik hier toch niet blijven, ze zal ze 'k ik toch weer naar mijn lante gaan,' zei hij.

- 'Maar wat trekt u daar zo bijzonder aan?' vroeg de Baron, 'gij zijt reeds sinds zo vele jaren van uw vaderland weg, en moet het hier gewoon zijn.'

'Ze is ze de geboortegronte,' sprak Giuseppe, terwijl hij uit al zijn kracht op de aarde stampte.

De Baron lachte. Hij kon het toch ook niet te weten krijgen, of Giuseppe getrouwd, en of Paoletto zijn kind was of niet.

De Heer van Mere scheen bijzonder opgeruimd, in weerwil van al het onheil, dat de storm had teweeggebracht. Hij vertelde het groot nieuws aan de glazenmaker: die zelfde morgen had hij zijn benoeming tot ridder der Leopoldsorde gekregen. Dit was de wens van geheel zijn leven geweest, en hij wilde, dat men een groot feest te zijner eer bereidde.

'Katerkeu, Katerkeu! Meneer de Bron, ze zal ze 't een sjernibleutse schone viering zijn,' sprak de Zwitser.

\section{IX}

Men was volop aan het versieren in het dorpje Meerkerke; want heden moest de Baron ingehaald worden. Geen huis, hoe klein ook, dat niet met zijn driekleurige vlag prijkte. Het liep al dooreen, timmerlieden met ladders op de rug, mannen en vrouwen met groene takken en sparrekens en stukken katoen. Er waren er die behangers uit de stad hadden doen komen; want men nam het ernstig op. De Heer van Mere had een prijs uitgeloofd voor wie het schoonst zijn huis versieren zou: twaalf zilveren lepels en vorken! En nu wedijverde men, dat het een genoegen was om te zien.

Lang vreesde men niet gereed te zijn; want te vijf uur moest de stoet voorbijtrekken, en elk had nog zoveel te doen, en wakkerde zijn huisgenoten aan zich te spoeden. Giuseppe zat op de hoge ladder aan zijn gevel, die hij ten volle met iepen takken en klimop wilde bekleden.

Conciper liep af en toe met nagels en hamers, en Paoletto en Po brachten de korven groen aan.

Men had het met de schrik ontstaan: ${ }^{21}$ te vijf uur was alles gereed en elk op zijn post. Het dorpje geleek aan een lusthof, en iedereen stond nu met gevouwen armen zijn eigen huis of dat van zijn gebuur te beschouwen. Het was nu nog niets; maar vanavond, dan zou het nog wat anders zijn, als de viering begon!

Welhaast hoorde men de muziek: het was het teken dat de stoet aankwam; want al de maatschappijen waren de Baron naar zijn kasteel gaan 
afhalen, vanwaar zij hem dan door het dorp tot aan het Gemeentehuis zouden brengen. Het kleinste meisje van de school, in 't wit gekleed en met een blauwe sluier, moest hem een overgrote tuil van zeldzame bloemen overreiken. Er werd hem ook door de stedelijke Raad een banket aangeboden, en des avonds zou hij met de burgemeester en de raadsleden de viering gaan zien.

Hij had aan de maatschappij Sinte-Cecilia te dier gelegenheid een nieuw vaandel geschonken van rood fluweel met gouden franjen en borduursel. Hoe fier kwam Giuseppe met het kostelijk voorwerp in de hand en de lederen riem over de schouder traagzaam vooruit, stap voor stap, recht voor zich starend met ernstig gelaat bij die plechtige intrede!

Met de duister ${ }^{22}$ begon men overal de lichtjes te ontsteken. Baas Van Hecke dong niet mee naar de prijs, en hield zich tevreden met enige kaarsjes aan zijn bovenvenster te plaatsen; maar bij Giuseppe daar liep men in rep en roer met de lichtjes, en lampjes, en lantaarntjes, die overal in het groen moesten gehangen worden. Conciper, Po en Paoletto hingen ze aan de haakjes rondom de vensters en omlaag aan de deur, Giuseppe moest de bovenste vastmaken, en klauterde als een kat op de trapjes, die langs beide kanten van de gevel in steen gevormd waren.

Op zijn zoldervenster prijkte een transparant ${ }^{23}$ met de woorden:

Vivat meneer de Bron van Mer-Castel!

In zijn waaier had hij mat glas gestoken, derwijze geslepen dat het een vurig erekruis verbeeldde, wanneer men er licht achter plaatste; maar zijn voornaamste stuk, waar hij het langst aan had gewerkt, en dat hem de grootste moeite had gekost, zijn meesterstuk, was een tweede transparant, dat geheel het ene benedenvenster bedekte, en in grote geschilderde letteren de volgende dichtregels lezen liet, door de Zwitser vervaardigd:

Wij vieren met genoegen,

Groot en klein daarbij gevoegen,

Daarom in uw lieden aandacht,

Ik viere met de macht!

Er was niemand die in al dat groen, en gekleurde lichtjes, en prachtige versierselen de oude gevel van Djosep de glazenmaker had kunnen herkennen! Men sloeg de handen samen van bewondering, als men zijn huis zag; men bleef in hopen voor zijn venster staan, en Giuseppe glimlachte, en ging ook in het midden der straat zijn werk aanschouwen, en wreef zich de handen, en zegde:

'Katerkeu! ze is ze toch nogal voldoende.'

De straten waren vol volk als op de kermis: men wilde alles van nabij bezien, en Po en Paoletto gingen hand aan hand zoals vroeger. Och! hoe klopte het hart van het kleine meisje bij het zicht van al die heerlijkheid, aan de zijde van haar speelmakker, wiens loden ringetje zij aan haar vinger droeg! Dat was de schoonste avond van geheel haar leven, haar kort, jong leven! 
Des anderdaags was in geheel het dorp geweten, dat Giuseppe de prijs van het schoonst vieren had, en allen waren het eens, dat hij hem had verdiend. Dat was een jubel en een feest in zijn huis!

\section{$\mathbf{X}$}

Paoletto en Po waren geen kinderen meer. Po was een groot meisje geworden, te hoog opgeschoten voor haar jaren, en 'zij ziet te bleek,' zei Bazin Van Hecke, maar Po's wangen waren bleek geworden, omdat zij Paoletto bijna nooit meer zag; want de jaren waren uit, wanneer jongens en meisjes tezamen spelen, en hij zocht haar niet meer op. De liefde, die zij voor hem als kind had opgevat, was met haar meegegroeid, en zij kon zich geen ander geluk voorstellen dan dat door hem bemind te zijn en zijn vrouw te worden.

Paoletto was wel een hoofd groter dan Giuseppe en een degelijk ambachtsman. Hij droeg nu ook de kas, wanneer zij tezamen uitgingen. Dikwijls zelfs mocht Giuseppe thuisblijven, en hij werd door hem vervangen. Als de jongeling voorbij het huis van Baas Van Hecke kwam, knikte hij vriendelijk en met zijn zoete glimlach op het jonge meisje, wanneer hij haar aan het venster ontwaarde, en dan was zij weer gelukkig voor die dag. Maar het gebeurde wel, dat hij 't vergat, en haar niet zag, en alsdan verviel zij in haar gewone treurnis, en haar sombere, wanhopige gedachten namen de overhand.

Het arme kind begon al het schrikkelijke van haar toestand te begrijpen. Neen, neen, dat zou hij niet doen, met een doofstom meisje trouwen: zij wist het maar al te wel! Ach, wat had zij niet gegeven om te kunnen spreken! Maar dan dacht zij weer, dat hij aan haar verbonden was, en zij draaide haar loden ringetje rondom haar dunne vinger. Hij had haar beloofd met haar te trouwen! Eilaas! zij voelde wel, dat hij het niet zou doen; er waren ogenblikken, dat zij het zelfs bespottelijk vond voor haar, arm misdeeld schepsel, de schone ${ }^{24}$ Paoletto aan zich te willen hechten.

Haar goede neigingen waren opnieuw verdoofd, en wat boos was, werd in haar gemoed weer opgeruid. Zij had soms een gevoel van haat tegen hem, en een dorst naar wraak, waarvan zij zich niet goed rekening geven kon. Zij wenste bijwijlen, dat hij naar zijn land zou terugkeren en nooit meer wederkomen, dan, tenminste, zou zij hem met geen andere zien trouwen.

Somtijds stond zij aan de ingang van het verwenste huisje, dat hij haar beloofd had herop te bouwen en er hun gezamenlijk tehuis van te maken, en zij wrong haar handen, en hield die ten hemel, alsof zij de wraak van hierboven op hem afsmeekte. $\mathrm{Zij}$ had hem willen verachten, verfoeien, vergeten: zij kon niet. Had zij dit kunnen doen, zij zou niet zozeer te beklagen

zijn geweest. Een enkele glimlach van hem deed al haar woede vallen, en wanneer hij naar huis kwam en voorbijging zonder acht op haar te geven, dan legde zij zich des avonds in haar bed, en weende, weende, omdat Paoletto niet ingekeken had, en omdat zij niet spreken kon. 
Paoletto was twintig jaar, en hij was nog niet eenmaal naar Zwitserland geweest, sinds hij hier woonde. Nu ging hij de lange reis ondernemen, en hij zou een vrouw meebrengen, zei hij aan zijn kameraden, die meenden, dat hij uit scherts aldus sprak, en hem niet geloofden. Giuseppe van zijn kant zegde, dat hij bereid was hem alles over te laten, en zijn lang gekoesterde wens te vervullen, om naar zijn vaderland terug te keren.

Paoletto moest het echter wel ernstig gemeend hebben; want hij schreef brieven op brieven aan Giuseppe, en Conciper vertelde overal, dat hij ging trouwen. Zekere dag werd de maatschappij Sinte-Cecilia verwittigd, op welke avond Paoletto met zijn jonge vrouw zou aankomen. Volgens gewoonte vergaderden de leden en bereidden zich om hem te tien of elf uur een serenade te gaan geven. De tijding had zich door geheel het dorp verspreid, en men speelde lustig voor het huis van Djosep de glazenmaker. Alles was op de been, wat maar gaan kon.

De arme Po bevond zich ook onder het volk: zij was ziek en hoestte. Paoletto stond in het deurgat met Angiolina, zijn Zwitserse bruid. Hij kon zich niet inhouden de maat te slaan. Zijn vrouw stond nevens hem. De blos der gezondheid lag over haar wangen; geluk en levenslust blonken in haar ogen.

Po zag de gloed, en de schaduw, en de rook der fakkels op de grote gevel wemelen. De muziek hoorde zij niet; maar telkens men op de grote trommel sloeg, voelde zij een siddering tot in haar voeten. 'Po,' zegde zij soms, en zuchtte, en haar borst gaf een zonderling geluid: het was als de reutel des doods, die uit haar keel opsteeg. Zij hield de handen krampachtig gesloten; zij wendde haar ogen van Angiolina niet af.

Wanneer men met het derde stuk bezig was, glipte zij zachtjes weg en ging in huis. Zij nam een handvol fosforstekjes ${ }^{25}$ en sloop weer langs de achterdeur uit. Haar benen wankelden onder haar; maar haar wil was de sterkste. Zij trad zachtjes langs het open poortje op het koerken van Giuseppe, en ging in het stalleken, waar de slijpsteen, de dubbele ladder, enige stukken beschadigd alem ${ }^{26}$ stonden, en waar de schavelingen en bakkerskolen lagen. Zij deed haar fosforkens branden, haar ogen staarden strak vóór zich, de hoeken van haar mond waren achteruitgetrokken en beefden, en zij stak met aarzelende hand de stekjes onder de schavelingen, die aldra vlam vatten en begonnen omhoog te laaien.

Zij voelde, dat het haar goed zou doen zich te wreken, en Paoletto's huis te verwoesten, en hem haveloos op straat te drijven met zijn vreemde bruid, hem, die al haar begoochelingen, al haar hoop op levensheil had vernield. Eilaas! het doofstomme kind kende niet ten volle het verschil tussen goed en kwaad: zij wist niet, hoe misdadig zij handelde!

Er steeg een alarmkreet op uit het volk: 'brand!' riep men, 'brand!', want de vlammen en de rook sloegen reeds boven de gevel. Po stond weer onder de menigte, en zegde met grote krachtinspanning 'Po', en wees op haar borst 
en toonde, dat $z i j$ het gedaan had; en telkenmale als zij zegde 'Po', hijgde zij naar adem en scheen niettemin lust te hebben om te beginnen te dansen. Doch er was niemand, die acht op haar gaf; men was volop aan het blussen: iedereen sloeg de handen aan het werk. Gelukkig lag er dicht achter het huis van Giuseppe een grote waterput, die men de Paterswal noemde.

Het duurde nogal lang, aleer men de vlammen meester werd; maar men gelukte er toch in het oude huis te bevrijden. Het stalleken was ten volle afgebrand, maar er was geen enkele onder de aanwezigen, die aan kwaadwilligheid dacht. Conciper geloofde de oorzaak van de ramp te zijn, en bekende, dat hij met zijn pijp, weinige ogenblikken voordat de brand ontstond, om schavelingen was geweest.

Baas en Bazin Van Hecke waren zodanig ontsteld van het gebeurde, en hadden zozeer gevreesd voor hun eigen woning, dat zij niet bemerkten, dat Po bij hen niet meer was. Misschien ook geloofden zij, dat het dove meisje niets had gehoord en in haar bed lag.

Als zij haar des anderdaags gingen wekken, was zij er niet. Hoe verschrikten de oude lieden! Hadden zij haar onwetend buitengesloten? Wat was er met haar gebeurd?

'Zij zal van schrik naar huis gelopen zijn', sprak Baas Van Hecke eindelijk om zijn eigen onrust te stillen, en die van zijn vrouw te bedaren, en zij zonden op staande voet een bode naar Smoregem, om te zien, of zij bij haar ouders was, terwijl zij hier ook in het dorp overal naar haar deden zoeken.

\section{XII}

Ja, Po was bij haar ouders: zij was er aangekomen in het midden van de nacht, en had hen opgeklopt. Het was als een spook, dat aan hun kamervenster verscheen: zij beefde in al haar leden, haar ogen stonden wijd open, haar tanden klapperden, en hier ook zegde zij verscheiden malen 'Po,' terwijl zij op haar borst wees, en deed teken aan haar ouders, dat het brandde in het dorp.

Zij hadden innig medelijden met haar: zij moet onder de indruk van een grote schrik weggelopen zijn, sprak haar moeder, en haar vader zei, dat hij zo gauw het dag werd, zich naar Meerkerke zou begeven, om te vernemen, wat er gebeurd was.

Po was zo moede, en afgemat, en uitgeput van krachten dat zij in bezwijming viel, zodra zij op een stoel neerzat. Haar moeder haalde azijn, en wies er haar voorhoofd en slapen mede. $\mathrm{Zij}$ weigerde alle voedsel. Men wilde haar warm drinken geven; doch zij wees het insgelijks af. Haar ouders zagen wel, dat zij zeer ziek was: haar moeder dacht, dat zij rust nodig had, omdat haar zenuwen zo hevig waren geschokt. Zij hielp haar ontkleden en legde ze te bed. Zij dekte haar zorgvuldig toe, en plaatste een nachtlichtje achter het hoofdeind op het tafeltje. 
Po viel aldra in een zachte slaap, naar het scheen; want haar ademhaling werd kalmer en regelmatiger. Haar moeder zette zich op een stoel aan de sponde: zij dorst de dokter des nachts niet opkloppen, maar wenste wel, dat het reeds klaar ware om hem te gaan halen. Ziende dat het meisje zo stil lag, liet de arme vrouw zich aan haar slaaprust over en sluimerde ook in. Het was dag, wanneer de vader binnenkwam, en zij wakker werd. Zij deed de buitenluiken open: de klaarte stroomde in de kamer, en zij verschrikte, als zij haar kind aanzag. Zij slaakte een angstkreet, die door de vader werd herhaald; want hij ook had de schrikkelijke wezenlijkheid erkend.

Po lag roerloos, en stijf, en uitgestrekt: Po was dood!

Op de jammerkreten van de ouders kwamen de kinderen binnengelopen; zij wisten niet wat er gebeurde. Vader en moeder weenden en snikten, en waren als van hun zinnen. Wat verwijten deden zij aan elkaar en aan zichzelf, de arme Po van huis gedaan te hebben en alzo de oorzaak van haar dood te zijn! De vader sloeg de handen in het haar, als wilde hij het uitrukken, en de moeder viel schreiend op de knieën, alsof zij aan haar kind vergiffenis vroeg voor hetgeen zij haar had misdaan.

De lieden uit het volk zijn luidruchtig in hun vreugd en hun lijden. Het deed hun goed door tranen en kreten verzachting in hun smart te zoeken.

En Po lag onbeweeglijk in het midden van al dat misbaar, het loden ringetje van Paoletto aan de vinger, met haar versmade liefde, haar opgekropt leed en haar gebroken hart!

\section{XIII}

Thans zou het uitkomen, wie Paoletto was, de trouwakte moest het vermelden. Paoletto was een onwettig kind, het kind van een jongere zuster van Giuseppe. Deze was vroeg gestorven, en men gelukte er in, de knaap te verbergen. Hij werd bij een verre neef, Gaettani, met de kinderen des huizes opgekweekt, tot hij groot genoeg zou zijn om met Giuseppe mee te gaan. Hij noemde ook zijn voedsterouders vader en moeder, en geloofde lang, dat hij heette zoals zij. Het was met het jongste dochtertje van Gaettani, Angiolina, de speelgenote van zijn kinderjaren, dat hij nu getrouwd was.

Giuseppe ging Vlaanderen verlaten: hij had het lang gewenst, en scheen er zich nochtans niet in te verblijden. Hij voelde de trek van een dubbel vaderland: hij had willen gaan en blijven, het was alsof zijn hart in tweeën reet. Hier had hij zijn jonge jaren in naarstige arbeid doorgebracht, en vreedzame dagen gesleten, en nu moest hij zich losrukken van alles, wat hij er ooit had bemind. Van zijn oude kennissen, van zijn alem, van al de voorwerpen, die hem omringden, en van Conciper!

Te Giubiasco was hij geboren en alles herinnerde er hem de spelen van zijn kindsheid. Daar had hij nog zijn oude vader en zijn oude moeder, aan wie hij alles had opgeofferd. Voor hen had hij vroeg het vaderland verlaten 
om in vreemde streken te gaan werken en zwoegen. Voor hen had hij nooit aan trouwen kunnen denken; want zij waren arm en hadden slechts hem alleen om voor hen te zorgen. En nu ging hij hun ouderdom verblijden door zijn terugkeer naar het vaderland; nu ging hij hen nooit meer verlaten.

Het speet alle mensen in het dorp, dat Giuseppe heenging, en menige vriend kwam hem nog op het laatste ogenblik de hand drukken. De oude Baas Van Hecke zegde met bevende stem: 'Djosep, het is de laatste maal, dat wij elkander zien.' Paoletto deed hem beloven binnen twee jaar terug te keren: het kon toch niet zijn een eeuwig vaarwel aan hen allen te zeggen. Hij beloofde het: 'Katerkeu! ze zal ze 'k het doen ook,' sprak hij.

Hij had aan zijn vrienden willen te kennen geven, hoe gevoelig hij was voor hun genegenheid, en hoe het hem smartte hen te moeten verlaten; maar hij vond zijn woorden niet: hij drukte hun de hand, zei verscheidene malen tot wederziens en vaarwel; doch hij deed geen stap: hij stond als aan de grond genageld, en schaamde zich over de tranen, die hij in zijn ogen voelde opwellen: hij moest al zijn krachten inspannen om die terug te houden.

Hij ging voor zijn knecht staan, en reikte hem beide handen: deze nam ze vast en schudde ze hevig en herhaalde malen. Zij zagen elkander aan: 'Conciper, Katerkeu, Conciper!' zei hij.

Conciper kon nog zoveel niet zeggen: de tranen hingen hem aan de wimpers en begonnen langs zijn wangen te rollen, en menigeen der aanwezigen haalde bij dit zicht zijn zakdoek uit en Giuseppe moest doen zoals zij. Hij had gehoopt moedig en als een man, en zonder blijkbare ontsteltenis afscheid te nemen; maar thans voelde hij, dat hij zich sterker geloofd had dan hij was.

'Katerkeu, ze is ze Conciper, die het hier al verbrodt,' sprak hij, terwijl hij met geweld zijn tranen afdroogde, zich weg haastte, en in de wagen stapte.

Wanneer Conciper het rijtuig hoorde voortrollen, en achter de hoek zag verdwijnen, vanwaar Giuseppe hem nog toeknikte, liet hij zich aan zijn droefheid over en begon luidop te wenen als een kind.

Paoletto woont nog met Angiolina in het oude huis, en is zeer gelukkig. Het is wel zelden, dat hij het Boomgaardje en het ingestorte huisje herdenkt; want het stomme meisje, met hetwelk hij er als knaap heeft gespeeld, is voor hem niets anders dan een herinnering uit zijn kinderjaren als zo menige andere.

Het gebeurt ook wel, dat hij te Smoregem werkt, en over het smalle kerkhofwegeltje nevens haar graf treedt; maar hij denkt niet eenmaal, dat Po daar ligt, ofschoon hij zo dicht bij haar voorbijgaat.

Februari, 1875 


\section{IETS OVER HET ONDERWIJS DER VROUW}

Er komt een treurig tijdstip in het leven der vrouw, dát wanneer haar zoontje begint te zien, dat zij onwetend is. Het kind is nieuwsgierig en weetgierig van aard en het is tot zijn moeder, dat het de gewoonte heeft zich te wenden om alles te vragen; zij is het, die hem zegt, dat het vogeltje uit het ei komt, dat het rupsje een vlinder wordt, en dat de bijtjes de honig uit de bloemen halen.

Als de knaap groter is, brengt hij wel eens zijn moeder in verlegenheid. Hij vraagt haar, waarbij het komt, dat de vensterruiten soms met damp overdekt worden; waarom een stok gebroken schijnt, als men hem in 't water steekt; en wat het is, dat de voorwerpen, die men op enige afstand ziet, ons veel kleiner doet voorkomen dan zij in de wezenlijkheid zijn.

Moeder antwoordt, dat hij zulks best aan Vader zou vragen, dat zij het niet weet, aangezien men zoiets aan de vrouwen niet leert. En dit is ook waar; zij weet het niet, enkel omdat men het haar niet geleerd heeft, en geenszins omdat zij zoiets niet leren kon.

Hoe groter de knaap wordt, hoe meer hij ondervindt, dat er veel dingen zijn, waarvan zijn moeder niet de minste kennis heeft. Teleurstelling volgt op teleurstelling. Het kind begrijpt, dat zij van nu voortaan zijn leermeester niet meer kan wezen, en daar zijn eigen oordeel nog niet gevormd is, gelooft het de treurige ontdekking gedaan te hebben, dat Moeder dwaas is en het schaamt zich over haar onwetendheid. Vandaar die onverdiende minachting, welke jonge schoolknapen niet zelden voor hun moeder en zusters opvatten, en die met hen opgroeit.

Wie kent er van die jonge pedantjes niet, die zich ver boven hun moeder en zusters wanen, omdat deze geen Latijn verstaan en geen Grieks geleerd hebben? De knaap heeft het Griekse alfabet leren schrijven en gelooft die taal machtig te zijn, omdat hij een Griekse spraakkunst en een Homerus onder zijn schoolboeken telt.

Als het wel eens gebeurt, dat een jonger broertje iets aan Moeder vraagt, haalt de grote de schouders op, alsof hij zeggen wilde: 'Vraag dat liever aan Vader of aan mij.' En niet alleen hij zelf, maar ook zijn zusters, die twee, drie jaar ouder zijn, beschouwen hem als een fenix en horen hem met bewondering aan, als hij het in het hoofd krijgt haar een brok uit Vergilius te reciteren, of zijn eigen Latijnse verzen op te zeggen, waarvan zij geen woord verstaan.

Indien het de vrouwen vergund ware dezelfde leergangen als de mannen te volgen, zou men er van beide zijden enkel kunnen bij winnen, de jongelingen zouden niet zo verwaand, de meisjes niet zo ijdel noch zo onwetend zijn.

Waarom dat groot verschil in de opvoeding van de knaap en die van het meisje? Volgens alle billijkheid heeft eenieder recht zijn geest te ontwikkelen in zover zijn natuur hem zulks toelaat. Waarom laat men de ene helft van 
een natie in onwetendheid opgroeien, terwijl men alles doet wat mogelijk is, om aan de andere haar volle ontwikkeling te geven?

In de Kamer der Volksvertegenwoordigers is er gezegd, dat de vrouwen niet heel en gans mogen verwaarloosd blijven, dat zij ook enigszins deel moeten nemen in het geestesleven; maar dat haar geleerdheid niet te ver mag gaan, dat meisjes geen geleerde vrouwen mogen worden. Waarom mogen zij dat niet, en waarom die naam als een schimpnaam aanzien? Een vrouw is nooit belachelijk, omdat zij te veel weet, maar wel, omdat zij soms verwaand genoeg is zich in te beelden, dat zij voor een geleerde kan doorgaan. Haar onwetendheid, niet haar kundigheden zijn schuld daaraan.

Kan men beweren, dat een jong meisje in de aardrijkskunde en de vaderlandse geschiedenis hoeft onderwezen te worden, en daarbij een paar vreemde talen aanleren moet, maar dat ze zich belachelijk zou maken, indien ze dan haar geleerdheid nog voor onvoldoende dorst aanzien en die wenste voort te zetten!? Overigens, indien men geraadzaam vindt aan de geleerdheid der vrouw een grens te stellen, wie zal daarmee gelast wezen? Zal het een bisschop of een minister zijn, die zal vaststellen, waar eigenlijk haar geleerdheid belachelijk wordt?

Zal de kunst haar ontzegd wezen; zal men de poort der wetenschap voor haar gesloten houden, of haar die met een spleetje openen?

Wat kwaad ware erin gelegen, indien de zuster goed genoeg geleerd ware om haar broeder te verstaan, als hij Vergilius of Homerus leest? Mannen en vrouwen zijn bestemd om tezamen te leven: ware het niet wenselijk hun dezelfde opvoeding te laten genieten?

Men heeft zich, enige tijd geleden, met de kwestie beziggehouden, of er niet enige veranderingen hoefden toegebracht te worden aan het programma, dat tot dusverre in de athénées ${ }^{1}$ gevolgd wordt. Men heeft zich gevraagd, of een jong mens, die zijn humaniora doet, geen nuttigere dingen zou kunnen leren dan het vervaardigen van Griekse thema's en Latijnse verzen. Wij zullen hier niet onderzoeken, wat een jong mens eigenlijk het best zou leren, wij willen alleen de wens uiten, dat men aan de meisjes hetzelfde lere als aan de jongelingen. Zolang de studie van twee dode talen voor de enen goed gevonden wordt, zal zij ook voor de anderen niet nutteloos zijn.

Men vindt er die de geest der vrouw met allerlei kundigheden zouden willen versieren, en deze beklagen het, dat ervoor haar geen universiteiten, evenals voor de mannen, gesticht worden. Wat zou dat baten, als men haar kindsheid verwaarloosd heeft? Indien van morgen af de deuren van onze hogescholen voor de vrouwen geopend wierden, wie van haar zou de leergangen kunnen volgen? Er hoeven studiën vooraf te gaan om van de lessen der hogeschool gebruik te kunnen maken.

Er is, weliswaar, geen wet, die de vrouw verbiedt haar geest te ontwikkelen. Het staat haar vrij alles te leren, waartoe zij lust of bekwaamheid heeft; maar moet men niet bekennen, dat zij zich in de onmogelijkheid bevindt zulks te doen? Indien een vader geraadzaam vond aan zijn dochter een klas- 
sieke opvoeding te geven, evenals aan zijn zonen, hoe zou hij dat tot stand kunnen brengen? Hij zou genoodzaakt zijn voor het meisje een professor voor ieder vak in het bijzonder te doen komen, en gevolgelijk zou hij daartoe overgrote sommen moeten besteden: er valt dus niet aan te denken.

Ware het niet rechtvaardig de vrouw in de gelegenheid te stellen haar geest te oefenen, en ware niet het beste middel daartoe het oprichten van meisjesgymnasiën, waarin juist hetzelfde programma als dat voor jongens zou gevolgd worden, en waarvan de leraars en leraressen zouden genoodzaakt zijn dezelfde proeven van bekwaamheid te leveren, die men nu van degenen eist, welke zich tot leraars van het middelbaar onderwijs bestemmen?

De mannen klagen wel eens, dat jonge meisjes en zelfs vrouwen, die tot een rijpe leeftijd gekomen zijn, zich enkel met beuzelarijen bezighouden, en over niets spreken kunnen tenzij over toilet en haartooisel. Aan wie de schuld? De geest, waaraan alle ernstige bezigheid ontzegd wordt, moet zijn krachten wel ergens aan besteden en is gedwongen zich met beuzelingen ${ }^{2}$ tevreden te houden.

Voor zekere klassen der maatschappij zijn de leergangen der humaniora als het dagelijks brood, dat aan allen zonder onderscheid uitgedeeld wordt. 't Is om het even voor wat vak de jongelieden zich bestemmen, zij gaan door die klassen. Het is enkel aan de hogeschool, dat hun wegen beginnen uiteen te lopen. Deze wordt ingenieur, gene advocaat, een derde geneesheer, een vierde doet geen universitaire studiën. Waarom zou de vrouw, voor het algemeen bestemd om huisvrouw en huismoeder te worden, die kostbare jaren, die de kindsheid van het huwelijk scheiden, niet besteden tot het aanwinnen van kundigheden, die haar levenslang tot nut en sieraad zouden verstrekken?

'Maar,' zegt men, 'als het meisje studeert gelijk een knaap, wanneer zal het tijd vinden om handwerk te leren?' Op school worden de jonge meisjes in het maken van allerlei fijne borduurwerkjes en tapisserie onderwezen; het nuttig handwerk leren zij meest thuis bij Moeder; ook is daar veel min tijd voor nodig dan de mannen weten. De vakantietijd is daar lang genoeg toe. Overigens zullen de jonge meisjes er wel zelf voor zorgen daarin niet ten achteren te blijven. Het ligt in haar aard met de handen te willen werken; zij kunnen reeds naaien en breien, als zij nog met haar pop spelen.

Sommigen beweren, dat er dingen zijn, waarvoor de geest der vrouw niet vatbaar is, en wij geloven het. Wij geloven, dat zij het misschien in geen enkel vak zo ver zou brengen als de mannen; maar dit is geen reden om haar opvoeding te verwaarlozen. Hoeveel jongelieden bevinden zich niet in hetzelfde geval? Maar wie zou het wagen hun te zeggen, dat zij van de studie moeten afzien, omdat hun geest te zwak is, en zij niet hetzelfde nut als hun meer begaafde makkers uit hun schoolgang kunnen trekken? De deuren der scholen staan open voor de weinig begaafden als voor de anderen.

Dat men ten minste de vrouw late beproeven, tot hoever zij haar geestvermogens ontwikkelen kan. Enige jaren zullen genoeg zijn om te bewijzen, wat zij leren kan, en waartoe haar verstand onvatbaar is. 


\section{HeT MEESTERSCHAP}

Indien een mens uit een ander werelddeel, ten volle onbekend met onze instellingen, de beschaafde Europese landen moest komen bezoeken, en toevallig het burgerlijk wetboek in handen kreeg, en op de formule viel, die het jong meisje bij haar huwelijk voorgelezen wordt, zou hij waarlijk geloven dat de Europese vrouw een soort van slavin is, aan wie de wet niet het minste recht toekent; hij zou moeten denken, dat zij in diepe vernedering gedompeld ligt, door haar man overheerst en in bedwang gehouden wordt zo lang zij leeft, en de minste van zijn wenken hoeft gade te slaan om hem in alles te eren en te dienen...

En zo daarna die vreemdeling het boek: The Subjection of Women, door J. Stuart Mill begon te lezen, zou zijn hart niet breken van medelij voor de verachte, miskende vrouw, die heel haar leven in afhankelijkheid en onderdanigheid doorbrengt onder het waakzaam oog van haar dwingeland-echtgenoot, die de schrijver aan een slavenmeester vergelijkt, en zou hij niet de verontwaardiging van de Engelse voorstaander van de miskende helft der mensheid delen en vinden dat het uur gekomen is waarop de vrouw moet opstaan tegen zo veel onderdrukking en geweldenarij van de zijde van de man wiens slachtoffer zij tot nu toe is geweest?

De reiziger zou het hoofd vol hebben van de woorden: dwingelandij, willekeurigheid, macht, geweld, gebod, verdrukking, die de heer Stuart Mill gebruikt waar hij van de man spreekt, en van de woorden: martelarij, gehoorzaamheid, onderwerping, wettelijke slavernij, die de schrijver bezigt telkens het de vrouw geldt.

Die vreemdeling zou waarlijk in zijn land kunnen terugkeren met de overtuiging dat de Europese beschaafde vrouw een erger lot heeft dan dat der vrouwen van zekere wilde volksstammen, die gedwongen zijn de man op de jacht te volgen om zijn zwaar gerief te dragen en het geschoten wild naar huis te slepen.

Gelukkiglijk is de vrouw niet zozeer te beklagen als de heer Stuart Mill het schijnt te geloven, en moet zij de deugden van de slavin zoals: de verdraagzaamheid, het geduld, de volharding, de zachtmoedigheid, de vleierij en de onderwerping, niet zozeer oefenen als hij het wel denkt, wil zij zich enige verzachting in de noodlottige toestand verschaffen, waarin de maatschappij haar heeft geplaatst.

Wanneer de wetgever in het burgerlijk wetboek neerschreef dat de vrouw aan de man moest gehoorzamen, dat zij hem moest beminnen en volgen, gaf hij hierdoor geenszins een bewijs van zijn zucht naar overheersing en dwingelandij; hij toonde enkel zijn zwakke zijde aan: zijn ijdelheid en de vrouw heeft aldra begrepen wat nut zij uit dit klein gebrek voor zichzelf kon trekken. 
De man vergt van het meisje dat hij tot vrouw neemt een aanerkenning van zijn meesterschap over haar, zijn eigenliefde voelt zich door die kinderachtigheid in de huwelijksformule gevleid, en het meisje van achttien jaar, zonder ondervinding en dikwijls zonder verstand, alleen door haar vrouwelijk instinct geleid, weet de ziel van de man te doorgronden: zij zal niet terugschrikken voor die belofte van volkomen gehoorzaamheid, zij weet dat het maar woorden zijn; ook om zijn ijdelheid te bevredigen noemt zij hem van op haar bruiloftdag tot op de dag van haar gouden bruiloft haar heer en meester, nochtans doet zij dit enkel onder de onuitgesproken voorwaarde, dat hij zich met die eretitel zal tevreden houden. Zij gunt hem gaarne die kleine zelfvoldoening, omdat zij er haar voordeel weet uit te trekken. Zij begrijpt dat haar macht des te groter is, als zij die kan verborgen houden.

De man houdt zich tevreden met de schijn, de ware heer en meester in een huisgezin dat is de vrouw, en het zij te harer eer gezegd: zij bewijst over 't algemeen dat zij er de bekwaamheid toe bezit, en als wij hier beweren dat zij meester is, willen wij geenszins hierdoor te kennen geven dat zij haar man onder de voeten trapt en hem ongelukkig maakt.

$\mathrm{Zij}$ is meester, en de man laat haar begaan. Alzo is het, en wat meer is, alzo is het goed: de man gehoorzaamt aan zijn vrouw, de broeder aan zijn zuster en de grootvader aan zijn kleindochtertje, wanneer haar ouders dood zijn en zij bij hem inwoont.

De vrouw gaat op een zeer behendige wijs te werk. Zij schijnt in alles de man te raadplegen, en weet de zaken zo in te richten, dat hij ten laatste gelooft dat alles in huis en buiten huis naar zijn wil geschiedt. Zij gaat zelden recht naar haar doel, zij verkiest bij voorkeur de omwegen en kronkelingen, en daar waar zij werkelijk gebiedt, kan zij de schijn aannemen van enkel een bescheiden raad te geven en de zaak waarover er gehandeld wordt geheel en al aan het oordeel van haar echtgenoot over te laten.

In de grond is zij het op wie alles rust, van wie alles goed gevonden of afgekeurd wordt. Iets waarin haar meesterschap vooral uitschijnt is in de opvoeding der kinderen; hieraan heeft de man niets te zeggen en hier is hij dikwijls in tegenstrijd met de moeder; ook daar de zaak zo belangrijk is, want de opvoeding beslist niet zelden over geheel de toekomst der zonen, gaat de man de strijd aan met zijn vrouw, maar zij volhardt in haar besluit en de knapen zo wel als de meisjes gaan naar de school die zij verkozen heeft. De vader ziet het met droefheid, doch hij is moede van strijden en geeft ten laatste toe om de vrede in zijn huis te bewaren, zegt hij. Later ook volgen haar kinderen de loopbaan die zij hun aangeduid heeft.

Zie een troep van arme landverhuizers naar den vreemde trekken, en spreek de zwervende familie aan, gij zult aanstonds gewaarworden dat het de vrouw is, die het vaderland heeft willen verlaten, en dat het de man is die haar volgt. 
Het is de kleine winkelierster, niet haar echtgenoot, die berekent of het beter en voordeliger voor het huisgezin ware de oudste zoon die in 't lot gevallen is, ${ }^{1}$ vrij te kopen of hem zelf te laten opgaan.

Het is de eigenaar-kruidenier niet, het is zijn vrouw die beslist of zij haar oude gevel met het ouderwets uithangbord zal blijven behouden, ofwel heel de voorzijde van haar huis doen afslaan en de kleine vensters door grote spiegelruiten doen vervangen.

Beschouw de opkomende fabrikant of bouwkundige, alle jaren groeit zijn fortuin merkelijk aan, en alle jaren ziet gij hem zijn levenswijs veranderen en zijn uitgaven vermeerderen, naarmate zijn inkomen verhoogt. Die man bekreunt zich niet veel over hetgeen er gebeurt; het is zijn vrouw die zegt wanneer het ogenblik gekomen is om een loge in het opera te huren, zich een buitengoed te kopen, en die beslist wanneer het gewin groot genoeg is om haar toe te laten koets en paarden te voeren.

Er zijn voorzeker menigvuldige uitzonderingen aan deze regel en eenieder kent mannen die meester zijn en hun vrouw onderdrukken, doch zulks bewijst niets. Zo iemand beweerde dat de man groter is dan de vrouw en meer lichaamskracht bezit, zou wellicht de barbiersvrouw van nevens uw deur dit betwisten en menen $u$ van het tegenovergestelde te overtuigen door zich nevens haar echtgenoot te plaatsen die een hoofd kleiner is dan zij, en al haalde zij nog twintig kleine mannetjes die een vrouw hebben van zes voet hoog, het zou niettemin waar blijven dat gij gelijk hebt, en de algemene regel is dat de man hoger van gestalte is dan de vrouw en haar aan lichaamskracht overtreft.

De man laat vrijwillig al de lasten des levens, buiten die zijner eigenlijke bediening, al de verantwoordelijkheid en al het gezag aan zijn vrouw over; dit komt omdat zijn geest zich niet zo goed tot de enge kring zou kunnen beperken waarin de vrouw leeft en werkt. Er is als het ware zelfs een zekere geestesbekrompenheid toe nodig om zich altijd binnen de palen der familiebelangen te kunnen houden. De man ziet alles in het groot. In politiek denkt hij aan de belangen des lands, de vrouw heeft enkel de toekomst van haar zonen voor ogen, en sluit zich aan de partij aan waarvan zij het groter voordeel voor hen verwacht. De man bekommert zich om de vooruitgang en de welvaart der mensheid, de vrouw enkel om de voorspoed van haar familie; zij is er wel wezenlijk de schutsgeest van, het middenpunt waarrond alles draait, de meester die alles gadeslaat en in orde houdt.

De reden van het meesterschap der vrouw is dus zeer licht om begrijpen en het is verwonderlijk hoe de man er een vernedering in ziet te bekennen dat zijn vrouw aan het hoofd van alles is. Hij lijdt er niet door, geheel zijn leven als een minderjarige behandeld te worden, maar hij zou erdoor lijden mocht hij de schijn van het oppergezag niet bewaren en wendt alle moeite aan om te tonen dat hij de baas is. Beide echtgenoten komen hierin goed overeen, de man neemt gaarne de schijn van het bevel aan en de vrouw die der onderwerping, ook laat zij geen gelegenheid voorbij 
gaan zonder te verzekeren dat haar man volkomen meester is in zijn huis en het alzo zijn moet.

De man doet studiën die gestadig zijn aandacht van zijn huiselijke kring aftrekken; hij dringt diep in de schoot der aarde om zich rekenschap te geven van de stof waarvan zij gemaakt is, en de veranderingen die zij heeft ondergaan. Zijn weetgierigheid bepaalt zich zelfs niet tot de dwaalster die hij bewoont en waaraan hij vastgeketend is: hij bestudeert de plekken in de zon en peilt de holte der bergen die hij op de maan ontwaart. Hij zoekt met het groot oog van de telescoop in de diepten van het luchtruim, en ontdekt planeten, en nebuleuzen, en staartsterren! Die man is niet geschikt om meester te zijn; hij heeft geen de minste behoefte naar heerschappij. Hoe zonderling dat hij zo aan de schijn houdt?

De vrouw maakt gewoonlijk geen misbruik van haar macht, daarom kan de man er zich zo goed in schikken. Hij voelt geen dwang, niet meer dan de oude heer die in een vreemde stad de weg niet weet en door het vijftienjarig dochtertje van zijn vriend naar zijn bestemming wordt geleid. Wanneer gij ze arm in arm ziet voortwandelen nu eens rechts dan eens links inslaan, dan dwars over de grote markt trekken, zou het $u$ dunken dat die oude heer gaat waar hij wil en het meisje hem volgt, en nochtans het is het kind dat hem leidt en de weg toont, en hij volgt haar en voelt geen dwang.

De vrouw laat haar man in veel dingen volkomen vrijheid: hij gaat regelmatig naar kiesgezelschappen en maatschappijen waar zij geen toegang heeft, dit is geen reden vindt zij om hem te huis te houden. Hij heeft vermaken die zij niet delen kan, zij benijdt hem die niet. Zij laat hem op jacht gaan en verzorgt dikwijls zelf zijn honden en bereidt hem zijn weitas. Zij zelf zou niet geneigd zijn vrouwenkringen in te richten waaruit de mannen gesloten zijn; maar zij begrijpt heel goed dat zijn natuur van de hare verschillend is, en dat het hem zou ongelukkig maken, moest zij hem dwingen uitsluitelijk in de familie en vriendenkring te verkeren waartoe haar leven zich beperkt. Zij weet dat zij daarmee genoeg heeft, hij niet.

Het jok ${ }^{2}$ dat de vrouw de man oplegt is dus licht om dragen en zij ontlast hem over 't algemeen meer dan zij hem hindert door haar meesterschap. Zij voelt dat zij het met verstand van zaken uitoefent en laat het zich niet ontrukken.

Waar is de echtgenoot die zou durven komen zeggen: ik heb zes of zeven van mijn vrienden uitgenodigd die zondag met ons zullen komen middagmalen? En waar is de vriend die de uitnodiging zou durven aanvaarden als die niet door de vrouw bekrachtigd wordt? Mr Bruis dorst toch niet in de Camera Obscura. ${ }^{3}$

De man zal er echter niets tegen hebben als zijn vrouw hem meldt dat er verscheiden vrienden van hun oudste zoon, die met hem op de Hogeschool zijn, de dag met de familie buiten komen overbrengen, zonder hem vooraf geraadpleegd te hebben of het hem gelegen kwam; hij vindt het zeer natuurlijk dat zijn vrouw uitnodigingen doet en de jongelingen die ver- 
wacht worden, hebben niet eens gewenst dat mijnheer ook bij de uitnodiging zou tegenwoordig zijn geweest.

De vrouw zegt tot haar kennissen: komt mij bezoeken; de man zegt tot de zijne: komt ons bezoeken. En degene van zijn vrienden van wie de vrouw niet houdt zullen er niet dikwijls komen, zij weet ze heel gauw uit haar huis te vervreemden, maar als het gebeurt dat haar man een antipathie tegen de ene of andere dame van haar kennis heeft, en deze laat blijken, en beweert dat het een kwaadspreekster is, zijn vrouw bekreunt er zich weinig over en de vriendin ook, al wordt ze gewaar dat Mijnheer haar niet opzoekt.

- Zij komt immers voor u niet, zij komt voor mij, spreekt de huisvrouw en indien haar gezelschap u niet aangenaam is, kunt gij weggaan, en de man vindt dat zij gelijk heeft en weet niets tegen haar gezegde in te brengen.

Het is waar dat gewoonlijk alle plannen en voorstellen van de man komen, want de vrouw heeft van haar natuur weinig initiatief, maar plannen en ontwerpen maken is geen bewijs van meesterschap. Het is de vrouw aan wie het voorstel onderworpen wordt, zij is het, die het onderzoekt en aanneemt of verwerpt, volgens het haar aanstaat of mishaagt, maar daar het wel dikwijls aangenomen en uitgevoerd wordt, zo kan zij licht aan de man doen geloven dat hij het is wiens wil geschiedt.

Waar is de man die zou durven een piano kopen voor zijn dochtertje, een rijpaard voor zijn zoon of een biljart voor zijn eigen vermaak zonder vooraf de toestemming van zijn vrouw verkregen te hebben? En waar zullen degenen, die zoals de heer Stuart Mill beweren dat de echtgenoot over alles wat de vrouw bezit mag beschikken, de man vinden, die verre van de goederen van zijn vrouw te verkopen, het wagen zou een enkel perceel van zijn eigen akker, of nog min, een reeks bomen, tot zelfs een enkele eik te koop te veilen, zonder dat zij hem zulks heeft toegelaten?

En de vrouw, wat durft de vrouw niet? Gij staat op het punt van uit te gaan, gij hebt nog de ene en andere kleinigheid op te tekenen of te verrichten aleer gij vertrekt. Drie mensen wachten ongeduldig dat gij heengaat, en aanzien elkaar met geheimzinnige blikken, maar verbergen $u$ haar ongeduld, dit zijn: uw vrouw, de naaister en uw vierjarig meisje. Er moet iets gebeuren binst ${ }^{4}$ uw afwezigheid, maar gij weet het niet.

Nauwelijks hebt gij de deur achter $\mathrm{u}$ toegetrokken of zij beginnen te glimlachen. $\mathrm{O}$, het kind is zo gelukkig, de naaister gaat hem oorringen insteken! Ze is bang, zegt de moeder, want het dunkt haar dat zij dat jong hartje voelt kloppen, doe het gauw, het is maar een kwade ogenblik. Maar de kleine zegt dat ze niet bang is, ze heeft te veel lust om oorbellen te dragen gelijk mama en een grote juffer te zijn, en toen de naaister haar kinderhuid doorboort, heeft dat meisje van vier jaar wilskracht genoeg over zichzelf om een traan weg te pinken die de smart haar in het oog drijft, en haar moeder aan te lachen, en te zeggen: het doet geen zeer.

Ja, moeder, gij durft wel veel, gij durft het engelenkopje van uw kind verminken, in vaders afwezigheid en als hij thuiskomt en het kleine meisje met 
de gloeiende oren en haar twee handjes aan de ringen bevindt om ze te ondersteunen, want het is als hing er een steen aan ieder oor zo zwaar schijnt dat in den eerste, dan ontvlamt hij in toorn, en werpt moeder harde verwijten toe omdat zij dit zonder zijn toestemming gedoogd heeft, zij die wist wat hij van zulke gruwzame sieraden denkt, zij die hem zo dikwijls heeft horen zeggen dat dit de beschaafde vrouw met de wilde gelijk stelt en dat zijn dochtertje nooit oorringen zou dragen, en de kleine, die hij tot zich roept om haar te troosten menende dat men haar misdaan en mishandeld heeft, loopt heen, uit vrees dat vader de ringen zou uitdoen en de wonde laten genezen.

Ja, zijn gramschap kent geen palen, hij doet bittere verwijten aan zijn vrouw en deze weent en snikt, maar het einde van dit alles is dat de toorn van de man ophoudt en de tranen van de moeder gedroogd worden, en dat het kind heel zijn leven zijn oorbellen behoudt.

Gij meent dat gij meester zijt omdat gij u niet zelden aan uw gramschap overlaat en opstand doet als er iets gebeurt dat u tegen gaat, maar dit is geen teken van krachtdadigheid, het is een bewijs van zwakheid. Het zijn de hulpelozen en de onderdrukten die tegen hun lot opstaan; zie de kinderen, zie Polen $^{5}$ hoe hun toorn soms uitbreekt en hoe zij zich verweren. Alzo gaat het met den man; hij schreeuwt en tiert als hij zich ergens wil tegen verzetten en zijn vrouw schreit en beeft bij het gerucht dat hij maakt, maar hij verkrijgt niets, wat zij wil moet geschieden.

De vrouw is er in gelukt de man te doen geloven, dat zij hem tracht te behagen, en dit gaat toch wel heel ver. Indien zijn ijdelheid hem niet verblindde zou hij aldra gewaar worden dat de vrouw zich aan hem niet gelegen laat; dit bewijst haar kostuum. De mannen hebben goed zeggen dat het van slechte smaak is, dat de vrouwen zich lelijk maken en misvormen door hun ongerijmde kledij en hun valse haren, zij mogen op alle wijze haar het belachelijke van een nieuwe mode tonen, de vrouwen bekommeren er zich niet in, zij zullen zelfs meelachen, en u uitlachen want zij zullen zeggen: wel, hoe kunt gij ons daarvoor misprijzen, wij doen het enkel om $u$ te behagen. En de man voelt zich gevleid en gelooft haar, maar zo hij haar eens vroeg haar krullen daar te laten en een eenvoudig kleed te dragen om hem te behagen, dan zou hij eens zien hoe weinig men zich om hem bekreunt daar waar er kwestie van opschik is.

Het is de schuld niet van de vrouw te willen heersen, het is haar natuur. Wanneer het gebeurt dat de rollen omgekeerd zijn en de man wezenlijk meester is, en alle dingen naar zijn wil inricht, dan is zijn vrouw diep ongelukkig, zij voelt alle ogenblikken dat zij een dwingeland heeft, zij kan aan haar toestand niet gewoon worden, en klaagt gestadig over haar lot. Ook wordt de echtgenoot voor zijn wrede handelwijs te haren opzichte misprezen en verfoeid van allen die hem kennen. De man die wil meester zijn drijft het ook te ver; hij zou zijn vrouw niet ten minste vermaak gunnen als zij dat vermaak buiten huis en zonder hem zou moeten genieten. 
De mannen oefenen over het algemeen een grote invloed uit op het hart en de geest der vrouwen die in hun omgeving verkeren omdat deze het overwicht van hun geestesgaven over de hare gevoelen en aanerkennen, maar de mannen houden gewoonlijk maar oppervlakkige gesprekken met jonge vrouwen en jonge meisjes, alsof zij het de moeite niet waard achtten over ergens een ernstig of belangrijk onderwerp met haar te spreken. O, vaders van familie, hierin misdoet gij veel. De vrouw luistert zo gaarne naar $\mathrm{u}$ omdat zij uit uw woorden zo veel leren kan, en gij hebt er alle belang bij de jonge harten te vormen die rond u kloppen, de gevoelens die er in ontkiemen als zo vele ranken te leiden en vast te vlechten, en de geest der vrouw te versterken, haar brein te verlichten, en haar gezichtskring uit te breiden, haar wat hoger te leren blikken en wat dieper te doen denken om van haar een degelijke huisvrouw te maken. Gij hebt ongelijk de jonge meisjes met minachting te aanschouwen en te verwaarlozen, want gij kunt hun opvoeding maken en hebt er gestadig de gelegenheid toe. Gij moet niet uit het oog verliezen dat zij het zijn aan wie uw zonen later zullen gehoorzamen.

Gehoorzamen? Dat woord klinkt misschien wel wat bars en stroef, maar er is er geen ander daar waar kwestie van meesterschap is. Overigens de man heeft niet te klagen want hij zelf kiest zijn meester, en zou hem gewoonlijk voor niets ter wereld willen missen. 



\section{Novellen van Virginie Loveling}




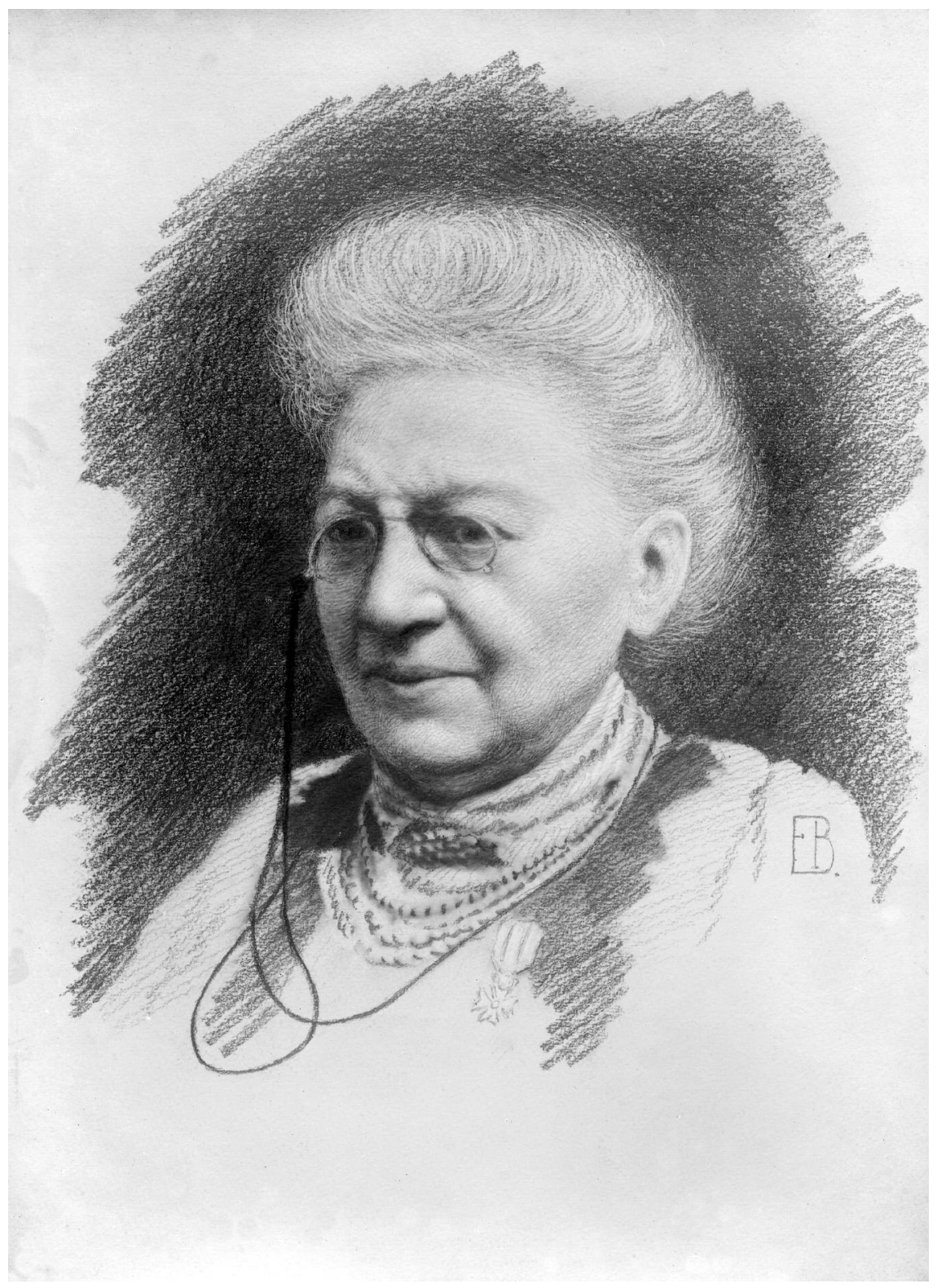




\section{DE KWELLENDE GEDACHTE}

Zij zou hem dus weerzien, de man, die zij vóór tien jaren had bemind en sinds lang zou vergeten en uit het oog verloren hebben, ware hij niet aan haar familie verwant geweest. Zij zou hem heden weerzien, en heel het verleden stond haar bij die gedachte voor de geest. Hij was schilder, hij had bij haar vader ingewoond. Zij was toen zestien jaar, en haar jonge en onervaren verbeelding had in hem iets verhevens, een uitzondering onder de mensen menen te ontdekken, en toen hij haar zijn liefde had bekend, had zij met vreugde toegestemd, dat hij haar hand aan haar vader vragen zou, en zij had zich een heldin gevoeld en zich bereid hem de wijde wereld in te volgen. Zij had een slapeloze nacht overgebracht, ${ }^{\prime}$ bevend de uitslag van zijn aanvraag verbeidend. - Eilaas, een bittere onttovering stond haar te wachten: haar vader - zij had het naderhand onderhoord ${ }^{2}$ - had het belachelijk gevonden, dat Épuron hem de hand van zijn jongere dochter vroeg: ' $\mathrm{Zij}$ is nog maar een kind,' had hij gezeid, 'indien het nog Julie ware, maar Césarine!'- Julie was een oudere zuster, die bij de grootouders was opgevoed en nog bij hen inwoonde. - 'Césarine is mijn liefste kind,' had hij, zonderling genoeg voor een vader, er herhaaldelijk bijgevoegd. En 's anderdaags morgens werd Césarine van huis weggevoerd, zonder Épuron weergezien te hebben, en Julie kwam terug.

Het jonge meisje was in vertwijfeling: haar scheen het toe, dat leven zonder hem geen leven mocht heten, en dat noch tijd noch afwezigheid zijn beeld ooit in haar geheugen zouden kunnen doen verbleken. Zij voelde zich machtig tegenover de wreedheid van haar vader, en met haar opgewonden karakter, dat door de vroegtijdige lezing van romans niet tot bedaren was gebracht, zwoer zij hem eeuwige liefde en onbreekbare trouw. Zij was nog geen zes maanden bij haar grootouders, toen ineens, voor haar gans overwacht, de tijding kwam, dat Épuron haar zuster had gehuwd, en hij met haar naar Parijs was vertrokken. Dit was een verschrikkelijke slag; maar de verontwaardiging over zijn trouwloosheid zelf matigde de wanhoop over zijn verlies. Ook van het ogenblik, dat haar vader kwam om haar terug te halen, en zo gans natuurlijk van Épuron en Julie sprak, juist alsof zij zelf nooit in aanmerking was gekomen, van dat ogenblik af begon zijn aandenken bij haar te verflauwen, en na verloop van een jaar of twee dacht zij nooit anders meer aan hem dan aan een schoonbroer.

La Conque haar vader was koper, verkoper en hersteller van oude schilderijen, hij won veel geld en had een tamelijk vermogen. Hij woonde te Gent in een enge straat, in een donker, smal, hoog huis, zijn eigendom, met 
zijn dochter en zijn zoon, die wel twaalf jaar ouder was dan zij. 'Césarine zal nooit trouwen,' zei de vader. 'Césarine zal bij mij blijven.' En het meisje glimlachte toen, en Éloi zei met een zenuwachtige schoklach: 'Wel zeker, Césarine zal doen zoals ik: ik ben immers ook bij u gebleven, Vader?' Dat was waar; maar het was tot groot verdriet van La Conque, dat Éloi nog thuis was; die gedachte vervolgde de oude man: zij was het, die hem vóór de tijd had doen vergrijzen, die de kwelling van zijn leven uitmaakte.

Éloi had jaren lang de medicijnen gestudeerd, hij had moeilijk en langzaam, weliswaar, maar met volharding verscheidene examens afgelegd; doch aan het laatste gekomen, had hij ineens de studie opgegeven, en zich van alle omgang met de mensen afgezonderd. Hij bleef dagen en weken in zijn kamer opgesloten om slechts op het uur van de eetmalen beneden te komen, en zijn vader kon door smekingen noch vermaningen van hem verkrijgen, dat hij zijn loopbaan niet roekeloos verlaten zou. En het had lang geduurd, aleer de oude man aan zichzelf had bekend, wat iedereen reeds wist, namelijk dat zijn zoon niet verantwoordelijk was over zijn daden, dat hij blijkbaar in de hersens was gekrenkt.

Césarine leefde tussen die twee mensen. $\mathrm{Zij}$ scheen hun beiden onontbeerlijk en had zich zowel in haar lot geschikt, dat zij niets anders vroeg van de wereld dan de liefde van vader en broeder. Ook toen de ene of andere zich aanbood om haar te huwen - hetgeen meest onrechtstreeks gebeurde, daar zij zorg had de liefdesverklaringen van haar aanbidders te ontwijken toen werd nooit tussen vader en dochter de vraag onderzocht, of het voorstel zou aanvaard worden of niet, en enkel geraadpleegd, hoe een weigerend antwoord op de minst kwetsende wijze kon worden gegeven. Zij wilde het niet aannemen, dat iemand haar ooit beminde, en zij kon zich van het vooroordeel niet ontdoen, dat eigenbelang degenen aandreef, die haar hand vroegen: er lag nederigheid, maar tevens mensenverachting in dit onderstellen. Épuron was lang vergeten - want welke hopeloze liefde weerstaat aan de invloed des tijds? - en wanneer zij thans aan haar ingenomenheid met die man dacht, vond zij die bespottelijk, en kon zij zich niet onthouden te glimlachen over zichzelf en haar onverlicht kinderoordeel van gene dagen, en was zij nieuwsgierig te weten, hoe prozaïsch haar ideaal eruitzien zou, thans dat haar opgewondenheid gestild en haar verstand gerijpt was. Dat hij een middelmatig schilder heette, had zij naderhand gehoord: hoe middelmatig zou hij haar thans gewis in alles voorkomen!

Maar nog iets anders zou zij nu kunnen opklaren, een gedachte, die haar vervolgde en kwelde. Julie was nooit meer naar huis gekomen, zij was opeens gestorven: er scheen een geheim over haar leven en haar dood te liggen, en haar vader sprak er niet gaarne over, als zij hem daaromtrent uitvroeg. Op het laatst van haar bestaan was eens een zonderlinge brief van haar in de handen van Césarine gevallen; want het gebeurde zelden, dat zij de brieven uit Frankrijk te zien kreeg, en sedert was een licht voor haar ogen opgegaan: Éloi was krankzinnig, haar moeder was het geweest - zij wist het 
van een dienstmeid - indien Julie eens krankzinnig gestorven ware? En indien Julie en Éloi krankzinnig waren - en die onderstelling deed haar huiveren en bedwelmde haar geest - waarom zou zij, Césarine, het ook niet worden...?

\section{II}

Zij zag hem weer. Met onbevangen gelaat en uitgestrekte hand was hij haar tegemoet gekomen, en met hartelijke broederliefde had hij haar omhelsd; en zij had hem even vriendschappelijk bejegend: het scheen vergeten, wat voor beiden in het verleden lag.

La Conque was verheugd zijn schoonzoon weer te zien: hij was hem altijd bijzonder genegen geweest, en thans kon hij ook zijn kleindochtertje leren kennen; want Épuron had zijn kind meegebracht: het was een tenger meisje met onrustige, schuwe blik, dat onbeweeglijk toezag en de liefkozingen van Grootvader en Tante weinig beantwoordde. Césarine was teleurgesteld een lichamelijk zo weinig ontwikkeld kind aan te treffen: Zénobie was omtrent negen jaar en scheen haar uiterst klein; dan dacht zij, dat zulks wellicht kwam, omdat zij geen vergelijking met andere kinderen maken kon.

Épuron was heel leven en beweging en vertrouwelijkheid. Van het eerste ogenblik scheen hij weer thuis in die bekende woning bij die oude, schier ouderwetse meubelen. Uiterlijk was hij niet gans meer dezelfde, met wat rimpels op zijn voorhoofd, hier en daar een zilveren draad in zijn zwarte lokken en een trek van vermoeienis of van vroegtijdige ouderdom, die soms plotselings zijn gelaat kwam verduisteren. In Parijs had hij afgezonderd geleefd, vertelde hij: dit was misschien oorzaak, dat het verblijf in de grote hoofdstad hem zijn oorspronkelijk karakter had gelaten, en hij er niets anders van had overgenomen dan een zekerheid van houding, een vlugheid van uitdrukking en die aanlokkelijke beleefdheid van sommige Fransen, welke belang stellen in al wat gij hun zegt, wier geest nooit uit uw tegenwoordigheid wegdwaalt, en die met een soort van eerbied en ernst naar uw onbeduidendste woorden zullen luisteren, een belangstelling, die dikwijls enkel schijnbaar is, maar toch immer vleiend voor u mag heten.

'En Éloi?' vroeg hij aan La Conque, verwonderd als hij was, dat zijn zwager hem nog niet was komen groeten.

- 'Gij zult hem aan het avondmaal zien,' antwoordde de vader, 'hij is op zijn kamer.'

'Altijd?'vroeg de andere.

- 'Meest altijd.'

Épuron stond op dit ogenblik alleen voor zijn schoonvader: hij stelde de punt van zijn wijsvinger op zijn voorhoofd en vroeg enigszins aarzelend: 'Is hij nog immer...?' hetgeen beduidde: krankzinnig.

'Ja', sprak La Conque met inspanning, maar alsof die bekentenis toch te 
zwaar viel voor zijn vaderliefde, 'min of meer', liet hij erop volgen. En na een poos: 'Marcel, het is jammer, jammer', zuchtte hij, 'men zou soms niet zeggen, dat hem iets hindert.'

- 'Kom, Bibi,' sprak de schilder, en trok zijn meisje bij om het gesprek een andere wending te geven, 'vertel eens iets aan Grandpapa.'

De oude man nam het kind tussen de knieën en zat enigszins verlegen wat hij haar zeggen zou, toen de deur openging en Éloi verscheen, Éloi, met zijn hoge schouders, zijn verglaasde blik en zijn slordig voorkomen, Éloi, de oude schoolmakker en de vriend van Épuron, die hem zenuwachtig de hand drukte met een pijnlijke glimlach voor welkomgroet.

\section{III}

Het avondmaal werd aangekondigd. Césarine sneed voor. Het kind zat nevens haar. Éloi dronk niet en at weinig: hij trommelde met de vingeren op zijn ledig glas, en scheen soms niet te luisteren naar hetgeen er gezegd werd. La Conque en Épuron spraken over kunst en kunstenaarsaangelegenheden, over het onrechtvaardige oordeel der kritiek en over de stoffelijke moeilijkheden, die de artiest in zijn loopbaan hinderen. Épuron klaagde, dat het hem tot hiertoe niet gelukt was de bijval te verwerven, waarop bij meende recht te hebben - elk kunstenaar gelooft aan zijn eigen talent - en van het weinig kunstgevoel der begoede klassen. Maar thans, vertrouwde hij hun, opende zich voor hem een nieuwe horizont: de Franse gezant van Den Haag was zijn beschermer: deze had hem de stellige verzekering gegeven, dat hij door zijn toedoen aan het Hof zou geroepen worden, om het portret van de Koning der Nederlanden te maken, 'en dit,' zei hij, 'zal mij ineens in de hoge wereld poseren.'

En toen La Conque hem op dit gezegde vroeg, of hij zich geen illusie maakte, haalde de schilder zijn zakboekje te voorschijn, en toonde hem een brief van zijn hooggeplaatste vriend, die zijn woorden staafde. Daarom was het, zei hij, dat hij naar België was gekomen: hij had het adres van zijn schoonvader opgegeven, en zou in geval hij ginder geroepen werd, aan Tante Césarine - thans noemde hij haar aldus - de toelating vragen Zénobie bij haar te laten, hetgeen hem dadelijk met voorkomendheid werd toegestaan.

'En gij, Éloi, waarmee houdt gij u bezig?' vroeg hij ineens zich tot zijn zwager wendend, in de vrees, misschien reeds te veel van zichzelf en zijn eigen zaken gesproken te hebben.

De zinneloze richtte zijn gebogen gestalte op en antwoordde fier:

'Ik studeer.'

- 'Dat weet ik wel', sprak Épuron, die niet bemerkte, dat La Conque hem teken deed van te zwijgen en dat Césarine verontrust scheen, 'dat weet ik wel; maar wat studeert gij?' 
'Op de kwadratuur van de cirkel en de altijddurende beweging,' antwoordde Éloi met uitgestrekte hand en statige zelftevredenheid.

Épuron kon een glimlach niet bedwingen; maar La Conque en Césarine luisterden kommervol: de huisgenoten lachen niet om de zonderlinge kuren of de wonderlijke spreuken van hun krankzinnigen.

'Ik zal het mensdom verbazen,' riep de zinneloze luid, 'want evenals Colombus geroepen was een nieuwe wereld te ontdekken, zo ben ik geroepen en voorbestemd om te vinden, wat nog geen genie vóór mij heeft ontdekt: de kwadratuur van de cirkel, die moeilijkste en volgens men beweert die onmogelijke oplossing van een mathematisch vraagstuk!' en hij lachte met zenuwachtige schokken.

Het kleine meisje keek haar oom aan met die gretige, onverholen nieuwsgierigheid, welke eigen is aan kinderen, en scheen hem de woorden uit de mond te zien. La Conque trachtte hem tot bedaren te brengen. Vergeefs, hij zat op zijn stokpaard, en nu eens de Franse, dan weer de Nederlandse taal gebruikend, begon hij verward en hoe langer hoe opgewondener en onophoudelijk door te spreken van de altijddurende beweging, waarvan hij het raadsel kende, van haar toepassing op de nijverheid, van de afschaffing der stoommachines, en de wereldverbazende omwenteling, welke zijn uitvinding in de wetenschappen zou voortbrengen. Zijn ogen rolden vervaarlijk, en een rode vlek was op elk van zijn bleke wangen verschenen, hij was opgestaan in de hevigheid van zijn alleenspraak, en zijn stem, die eerst helder was, had allengs haar toon verloren, zodat zijn woorden thans in een schor geluid vergingen, en er soms geen klank uit zijn mond meer kwam. Césarine was radeloos: zij stond recht en trok aan zijn arm, en aan een inval, die zij op dat ogenblik voor goed hield, gehoor gevend, fluisterde zij hem in 't oor: 'Éloi, Éloi, wat denkt gij wel, dit allemaal uiteen te doen; zo eens Marcel of iemand anders, door uw openbaringen ingelicht, op de gedachte kwam zich uw uitvinding toe te eigenen...?'

Die woorden oefenden op de krankzinnige een plotselijke onverwachte invloed; hij balde dreigend de vuist, als wilde hij zeggen: 'Wee degene, die het wagen zou!' maar sprak niet meer. Césarine ontstak de koperen blaker, die op het schouwbord gereed stond; want in die tijd en in die woning was dat aartsvaderlijk gebruik nog in zwang, gaf hem die in de hand en zei hem van naar bed te gaan, en hij gehoorzaamde als een kind.

\section{IV}

Épuron zag beschaamd voor zich en bad om verschoning.

'Het is mijn schuld,' zei La Conque, 'ik had u moeten waarschuwen, dat het gevaarlijk was die snaar aan te raken. De oude man zuchtte en in zijn spijt over het gebeurde, zegde hij veel meer om zijn mistroostigheid lucht te geven dan uit overtuiging: 'Die kleine dáár zit te laat op, Épuron; zij moest 
al lang in haar bed zijn.' Hij voelde zich in zijn vaderliefde vernederd tegenover dat kind. Deze zag er zeer wakker uit, en scheen niet de minste noodwendigheid van slapen gaan te gevoelen; maar Épuron zei zacht en gebiedend 'ga, Bibi' en het meisje stond op, en liet zich onbeweeglijk van Vader en Grootvader op het voorhoofd kussen, en trok naar boven met Tante Césarine, die ook goede nacht gewenst had.

De beide mannen bleven stilzwijgend zitten, als wachtten zij naar elkander om een gesprek te beginnen, dat voor beiden even pijnlijk moest zijn, en voor hetwelk zij terugschrikten. Het was de oude man die eerst de stilte brak: 'Marcel, wij zijn alleen: zeg mij iets van Julie?' vroeg hij ontroerd.

- 'Ik heb veel, heel veel met haar afgezien, Vader, was het droevig antwoord.

'En hoe is het haar aangekomen?'4

- 'Langzamerhand. In den eerste hield ik het voor grillen, en trachtte haar tot bedaren te brengen, maar onmogelijk, en daar er tussenpozen van gezonde rede zich bij haar opdeden, ${ }^{5}$ duurde het lang, eer ik de schrikkelijke waarheid te weten kreeg; het kwam haar immer weer aan met een soort van schroom en wantrouwen...'

'Juist als haar moeder,' zei de rampzalige grijsaard met gebogen hoofd, en na een poos opziende: 'Épuron, van dit alles weet Césarine niets; maar zij heeft vermoedens, haar verbeelding is getroffen: zij is somtijds angstig en gejaagd, en zo zij de waarheid moest onderscheppen, zou ik ook voor dàt kind te vrezen hebben. Indien zij het van Zénobie eens trachtte te weten?'

- 'Zénobie,' zei haar vader met een soort van minachting: het was alsof hij het meisje die tedere gevoelens niet toedroeg, die men van zijn liefderijk gemoed en zijn vaderhart had mogen verwachten, 'Zénobie weet daar niets van; overigens zij was toen nog zoveel jonger, en een kind bemerkt zoiets niet, als het hem niet gezegd wordt.'

'Épuron,' hernam La Conque op smekende toon, 'beloof mij, indien Césarine u ooit van Julie sprak, haar kost wat kost de waarheid te verbergen.'

- 'Goed,' antwoordde de schilder.

Maar als koesterde La Conque nog vrees voor een onvoorzichtig woord van zijn schoonzoon: 'Beloof het mij,' zei hij, 'op uw eer en uw geweten.'

- 'Ik zweer het u,' sprak Épuron de rechter hand op zijn hart drukkend, en weinig dacht hij zeker op dat ogenblik, hoe duur die eed hem eens zou te staan komen!

Césarine had het meisje in haar beddeken gedaan, dat zij in haar kamer had laten plaatsen uit bezorgdheid dat de kleine des nachts iets mocht nodig hebben. Zij was zenuwachtig opgewekt en kon voor zichzelf nog aan geen 
slapen denken. Zij liet het licht branden en ging in het kamertje daar nevens, de deur achter zich toetrekkend. Het was een klein vertrek, dat met een venster op het water gaf: een smal, zwartachtig, staand water, langs welks overkant een hoge, donkere fabriek zich verhief, waarvan het tergend geronk het kamertje bij dag onbewoonbaar maakte. Zij legde zich door het raam en blikte in de duistere nacht. Het was een zoele, onweerdreigende meilucht; zwarte wolken hingen over haar hoofd, en een flauw weerlicht schoot soms een vluchtige straal zonder donderslag uit de verte over het water.

Zij onderging de ongenoeglijke invloed van het onweder, en werd bestormd door allerlei tegenstrijdige gevoelens en gewaarwordingen, die zij trachtte te doorgronden, en waaruit het haar voorkwam, dat zij moeielijk klaar kon worden. Het beeld van Épuron zweefde voor haar blikken: hij scheen haar even geestrijk en verleidend als vóór tien jaar; en een treurig herdenken aan wat zij om zijnentwille had uitgestaan, en een besef van de onmogelijkheid om het verleden te vergeten, en tevens van voldane eigenliefde over de standvastigheid van haar oordeel, nu zij ondervond, dat haar rijpere geest de keuze van haar vroegere jeugd billijkte, doormengd met een langvergeten, nieuw opgewekte wrok ten opzichte van haar vader, die haar geluk had belet, en van Épuron zelf, die haar niet genoeg had bemind om te volharden in zijn streven - dit alles tezamen gesmolten in een oneindig weegevoel over zijn verlies, lag verward en kwellend in haar geest en deed haar harte kloppen. Het pijnlijke toneel met Éloi, iets dat bij de vreedzame aard van zijn krankzinnigheid zo zelden plaatsgreep, de herinnering aan Julie, aan die zuster, met welke zij niet was opgevoed, en die haar alles had ontnomen, de onzekerheid over haar lot, en de tegenwoordigheid van dat kind, dat zij met uiterlijke liefde verzorgde, maar tot hetwelk zij zich verweet geen trek te gevoelen, dit ook droeg niet bij om haar verbeelding te stillen.

Zij wist niet, hoelang zij door het raam had gelegen; maar toen zij weer in haar slaapkamer kwam, op de tenen gaande om Zénobie niet te wekken, zag zij deze recht in haar bed zitten, en verschrikte zij bij de aanblik van haar bleek gelaat en de scherpheid van haar schoudertjes, welke het wit nachtgewaad nog meer deed uitschijnen.

'Zénobie, kunt gij niet slapen dan?' vroeg zij in de landtaal van het kind.

- 'Neen,' zei de kleine.

Césarine zette zich op de rand van haar beddeken, en nam haar handje vast, dat koud was en beefde. Ineens dacht zij, dat het meisje wellicht bang was in de vreemde woning, en vroeg haar, of zij haar weer beneden bij Papa wilde leiden.

'Neen,' schreeuwde het kind met een schielijke aanval van schrik, sloeg haar armkens om de hals van Césarine en verborg het hoofdje tegen haar borst.

Césarine kon niet begrijpen, hoe het kwam, dat de kleine voor haar goede vader schrikte, en suste en streelde haar, overtuigd, dat deze onder de invloed van een bange droom verkeerde. Weldra hoorde zij de stappen van 
de beide mannen op de trap, en het scheen haar, dat bij dit gerucht de tengere armkens haar vaster omklemden. Lang zat zij op het beddeken: zij liet haar kin op het kleine hoofdje rusten, en wiegde aan haar hart het kind van Julie en Épuron, totdat de tengere ledematen slap vielen, en zij het ingesluimerd meisje op de peluw neerlegde en met moederlijke zorg toedekte, waarna zij zich ook ter ruste begaf.

\section{VI}

Toen Césarine 's anderdaags verkwikt ontwaakte, was de kleine Zénobie reeds uit het bed, en beneden komend zag zij haar in de open kelder onder de trap, waarbinnen zij de meid hoorde, reikhalzend staan turen. Zij vermeed van het gebeurde van de vorige avond een woord te reppen, en leidde haar in de eetzaal, waar de andere huisgenoten haar aan de ontbijttafel wachtten. Éloi was stil en sprakeloos als immer, en Épuron helder van geest en gemoedsstemming. Ook de storm van haar hart had zich gelegd, en het scheen haar nu, dat de rust er nooit was gestoord geworden.

Toen Éloi weer naar zijn kamer, en haar vader naar zijn werkplaats was, toonde Épuron haar een hele verzameling van allerlei kleine schetsen, sommige met kleuren, andere enkel met zwarte kool getekend. Enige daaronder stelden haar zuster en de kleine Zénobie voor in verschillende houdingen en klederdracht. Sommige waren met zorg afgewerkt, andere enkel ontworpen of onvoltrokken; maar op alle stond de moeder met het kind als een beeld van huiselijk geluk en vrede. Hij glimlachte zoet, als hij haar dit beurtelings toonde, en zij voelde met een soort van stille weemoed veelmeer dan van spijt, hoe verre hij met zijn gedachten van haar was geweest, in de tijd, toen zij nog treurde over zijn verlies; maar zij nam met oprechte belangstelling het ene blad na het andere in de hand, en hoorde zijn uitleggingen aan.

Intussen was Zénobie onbemerkt uit de kamer geslopen, en trok de trappen op, stil en zonder gerucht te maken, tot op het hoogste van het huis. Haar navorsend oog zag in het ronde: zij ontdekte de werkkamer van haar grootvader, onder het dak, waar een groot vierkant raam een met planken afgeslagen zaal verlichtte: dit was de enige heldere plaats van die duistere woning. La Conque scheen gevleid, dat zijn kleindochtertje hem kwam opzoeken, en trachtte haar door zijn vertellingen bij zich te houden; maar de werkkamer van een schilder met haar toebehoorten was haar niets nieuws, en scheen, evenmin als Grandpapa, haar weinig belang in te boezemen, en van een ogenblik gebruik makend, dat hij aandachtig aan zijn doek penseelde, trok zij omzichtig weer naar de lagere verdieping. Daar was een kromme donkere gang, waarin verscheiden deuren uitkwamen; zij draaide aan de appel: twee van die deuren waren gesloten, van een derde was het bovenste deel in glas. Zij hief zich op de tenen en blikte naar binnen: er 
stond een ledig bed, waarin grote bestoven pakken oude gazetten toegebonden lagen, nevens een geblutste manshoed en de afgebroken leuning van een stoel. Er stonden schilderijen naar de muur gekeerd; er was een venster met een verdroogde bloemstruik op de rand, en zij zag daarbuiten een pannen dak en een rokende schoorsteen.

Aan het verste einde van de donkere gang viel een rechte lichtstraal door een spleet: de deur stond een weinig open. Als een sluipdier was het kind genaderd; daarbinnen zat Oom Éloi voor een tafel aan een grote lessenaar te schrijven, dat was zijn studeervertrek. Er lagen hopen boeken en papieren verward ondereen; maar het overige van de kamer kon zij niet zien, en een onweerstaanbare nieuwsgierigheid dreef haar aan, een kleine duw aan de deur te geven, die licht op haar hengsels hing en half openvloog. Zij wilde zich terugtrekken; maar Éloi had opgekeken: hij riep haar binnen, en haar begeerte sterker zijnde dan de vrees, die hij haar inboezemde, zo volgde zij zijn roep.

Die kamer was met een tred op, zodat het plafond heel laag scheen. Allerlei zonderlinge voorwerpen waren er te zien: schelpen, en beenderen, en stenen op de schouw. Er stond ook een kleine bibliotheek, waarin zo weinig boeken waren, dat zij schuins naar elkander toe of gans neergevallen lagen. Ontelbare bestoven flesjes bevonden zich op de hoogste rijen. Éloi toonde haar dozen met een glazen deksel, die hij uit een eiken kast nam, waarin verzamelingen van vlinders en kerfdieren ${ }^{6}$ in verbazende hoeveelheid vaststaken: er kwam een sterke kamfergeur uit. Hij had het manuscript, waaraan hij arbeidde, toen zij binnenkwam, in de zak gestoken, en tastte er gestadig naar, als vreesde hij het te verliezen, of dat hem geroofd zou worden. Eindelijk opende hij de lessenaar om het erin te leggen, en haar oog viel op een pak brieven met een zwart lintje kruiswijs vastgebonden. 'Dat is alles van uw moeder,' zei hij haar schoklachend, het pak dicht bij haar aangezicht stekend, waarna hij het even ras terugwierp, de lessenaar toesloot en er de sleutel onder verborg. Op tafel lagen passers, en een grote wereldbol stond in het midden; maar hetgeen meest haar aandacht trok was een wit-en- roodgeruite gordijn, dicht toegeschoven, welke in de duistere hoek van de zaal hing, en waarachter iets geheimzinnigs verborgen scheen. Een zonderlinge machine met een groot glazen wiel, dat tussen twee kussens gevangen zat, en bokalen meer dan te halver hoogte met lood beplakt, en waaruit een gekromde metaaldraad met een koperen appel door een kurk stak, een zwart-en-witgevlekt kattevel op een zwarte, met pek overstreken schijf, en allerlei zonderlinge voorwerpen stonden of lagen aan de andere kant: dat was een elektriseermachine, zei de krankzinnige, en hij voegde erbij, dat hij er vonken uittrekken en haar een geduchte schok zou doen gevoelen, maar dat zij niet schreeuwen mocht, en meteen wilde hij haar vastgrijpen, en zijn ogen rolden, en hij lachte vervaarlijk! Doch de schrik scheen haar vleugelen te geven: in een omzien was zij hem ontsnapt en uit zijn kamer, en zij liep donderend de trappen af. 


\section{VII}

In die tijd bestond juist buiten de stad een eenzame, lange wandeling, welke van de Dampoort naar de Muidepoort geleidde, met hoge kaarspopulieren beplant, een tamelijk breed, met groen bedekt water links, en rechts de uitgestrekte weiden tussen Gent en Oostakker. Ik geloof, dat dit het Kleine Dok genoemd werd. Daar had Césarine in haar kindsheid vaak met Éloi en Marcel gewandeld. De wilde ranken van de wrange ${ }^{7}$ groeiden er ongestoord aan de overkant, en de wind mocht er vrij in het lis en de hoge bomen spelen. Zelden was er een levend wezen te zien.

Épuron wachtte nog altijd de beslissende tijding uit Den Haag, en deed intussen lange wandelingen met zijn kind en Tante Césarine. Daarheen richtten zij dan ook van in den eerste hun schreden. Van het verleden werd nooit gesproken, juist als hadden zij geen enkele gemeenschappelijke herinnering gehad. Hetgeen daar ook misschien toe bijdroeg, was de bestendige tegenwoordigheid van de kleine, die geen stap van hun zijde week, en gretig de woorden uit hun mond scheen op te vangen. Épuron had wel haar Tante te verzekeren, dat Zénobie geen Nederlands verstond, hetgeen door het kind bevestigd werd, Césarine had er geen trouw in, ${ }^{8}$ en was terughoudender dan zij wellicht anders zou geweest zijn.

Eens op een zonnige namiddag op het einde van de meimaand, waren zij weer hun geliefd pad ingeslagen: zij hadden zich halverwege op het groene gras gezet, en blikten over de verre weiden, die met allerlei bonte schakeringen van wit en groen, en grijsachtig en rozerood, en geel en wit voor hun ogen uitgestrekt lagen. Hetzij het zitten en de gestadige waakzaamheid, die zij uitoefende, Zénobie begonnen te vervelen, hetzij de meersbloemen haar kinderlijk verlangen onweerstaanbaar uitlokten, althans zij ving aan een tuil vergeet-mij-nietjes en rode molekens te plukken, en wendde vergeefse moeite aan, om ook de lichtlila hottonia's ${ }^{9}$ vast te krijgen, die zich voorzichtigheidshalve steeds in het midden van de grachtjes houden.

Césarine zag rond; zij was alleen met hem: 'Marcel', zei zij, 'er is een denkbeeld, dat mij kwelt, en gij, gij alleen kunt mij de rust weergeven: zeg mij,' en zij zag hem vlak in het aangezicht met haar klare bruine ogen, 'zeg mij, is Julie niet zinneloos gestorven?'

Hij ontweek haar blikken, en antwoordde, terwijl een trek van ongenoegen op zijn gelaat verscheen: 'Maar Césarine, hoe komt gij op die gedachte? Wie heeft u zulke ongerijmdheden in het hoofd gestoken?' en hij poogde te glimlachen.

- 'Niemand,' zei zij, 'maar alles draagt bij, om mij in die overtuiging te versterken: zij zweeft over ons huis, zij ligt in de lucht, die ik inadem, en wat mij haar het eerst heeft ingegeven, Marcel, dat was die zonderlinge brief van Julie...'

'Welke brief?' vroeg hij verschrikt.

- 'Op het laatst van haar leven,' hernam zij peinzend, 'het was een 
gewone, onbeduidende brief aan mijn vader; maar op het einde waren met inzicht verscheiden zwarte vlekken aangebracht, en daaronder stond geschreven: (dit zijn gedachten, die ik in mij opgesloten houd). Een wijs mens schrijft zo iets niet. En omdat mijn moeder ook en Éloi insgelijks...'

Épuron lachte ditmaal met verlicht hart, omdat haar vermoedens op geen vastere gronden steunden, en zei: 'Wel, Césarine, dat zal een grap van Julie geweest zijn!'

Het meisje deed een laatste poging: 'Marcel', sprak zij, 'denk niet, dat ik te zwak ben om de waarheid te vernemen; van mijzelf ben ik zeker: nooit zou de krankzinnigheid bij mij aanstekelijk kunnen worden, denk dat niet,' en zij zag hem zo vreemd en onrustbarend aan, dat het hem moed gaf in zijn loochening te volharden, en hij het met zulk goed gevolg deed, dat zij voor het ogenblik volkomen van zijn woorden overtuigd scheen.

'Wat ben ik blij,' hernam zij, 'ik wilde het u niet zeggen, Épuron; maar mijn hoofd is soms zo bedwelmd, mijn verbeelding neemt de bovenhand op mijn rede. O!' en zij drukte haar handen op haar slapen, 'en hier spant en klopt en gloeit het dan zo vervaarlijk, en ik verbeeld mij, dat ik zinneloos moet worden, omdat de waanzin in onze familie erfelijk is; want indien Julie het ook geweest ware, hoe zou ik alleen overschieten...?' Zij sprak nog lang op die toon, en hij stilde haar onrust en juichte inwendig, dat hij door zijn behendige leugen al haar bekommeringen had verdreven.

Arme Épuron!

\section{VIII}

Des anderdaags waren zij opnieuw uitgegaan, en aan het Kleine Dok gekomen, maakte Césarine reeds een beweging om in te slaan; maar Épuron ging rechtdoor: 'Waarom niet elders eens gewandeld om af te wisselen?' vroeg hij, 'laat ons liever eens naar het Zandheuveltje gaan.'

Het Zandheuveltje...! Dat was een kleine met ginst en heestergewas begroeide hoogte nabij het kerkhof van Sint-Amandsberg. Men wist niet, of het deel maakte van een bijzonder eigendom, of een soort van woeste, openbare, hoge plek was, die midden in het zorgvuldig bebouwde, platte land nog onvruchtbaar lag. Maar wat Césarine heel goed onthouden had, was, dat op het Zandheuveltje Épuron haar voor de eerste en enige maal in zijn leven van zijn liefde had gesproken. Zij had het sedert niet meer bezocht; maar het was innig en onafscheidbaar met die herinnering van haar jeugd verbonden.

De toon, waarop hij van het Zandheuveltje gewaagde, was echter zo natuurlijk, zo onverschillig, dat Césarine niet twijfelde, of hij had het vergeten, wat hij haar daar had toevertrouwd, en zij vreesde te laten merken, dat zij het onthouden had, indien zij zich tegen deze wandeling verzette: 
zij ging dan gewillig en nadenkend aan zijn zijde, en sprak soms een onverschillig woord met hem of de kleine Zénobie.

Zij klommen op het heuveltje: daar was nog niets veranderd, en de eikenstruiken stonden even groen, en de ginstbloemen even goudgeel, en het varenkruid even statig, en de braamranken lagen even wild over de grond als vóór tien jaren. Hij wandelde, of veelmeer brak door de boomgewassen, en nodigde haar eindelijk uit zich aan zijn zijde neer te zetten. Was het toeval of keuze? zij bemerkte, dat hij hetzelfde plekje had uitgekozen, waar zij weleer eens tezamen hadden plaats genomen, terwijl Éloi tussen de heesters om hen heen kruiden zocht.

Vóór hen in de verte, met een lichte damp omgeven, rezen de torens van de stad. Een zoele meiwind suiselde door het loof en streelde hun wangen. Zénobie was weggelopen, en lang zaten zij sprakeloos, elk in zijn dromen verdiept. Het was, alsof dit oord een tovermacht over Césarine uitoefende: een onuitsprekelijk gevoel van vrede, en betrouwen, en rust lag over haar hart. Haar gedachten waren onduidelijk; maar zij wenste in alle eeuwigheid daar sprakeloos aldus nevens hem te mogen zitten, in het bewustzijn van een grenzeloze zaligheid.

'Césarine,' begon Épuron eindelijk, niet met die plotselijke, verrassende toon van iemand, die het besluit vat een moeielijk onderwerp te verhandelen, maar veelmeer als luidop denkend in de tegenwoordigheid van een geliefd wezen, 'Césarine, hier was het, dat wij vóór tien jaar ook eens tezamen zaten, heugt het u nog, Césarine?'

Zij zweeg en een diep rood overtrok haar voorhoofd, dat zij onder haar handen verborg.

'Waarom,' hernam hij, 'moest ik mij van uw vader laten overhalen om Julie te huwen, Julie, die ik niet beminde, Julie, die ik nooit oprecht heb kunnen beminnen, Julie, met welke ik zo ongelukkig ben geweest?' en hij vaagde een traan uit zijn ogen. 'Césarine, ik zal niet trachten mij te ontschuldigen: ik heb deze daad verschrikkelijk geboet,' sprak hij somber, en met onbeschrijfelijke zachtmoedigheid hernam hij na een lang stilzwijgen: 'Césarine, ik bemin u nog als vóór tien jaar, Césarine, kunt gij vergeven en vergeten?'

- 'O ja,' sprak het meisje bewogen.

De ginststruiken achter hen ritselden onheilspellend: zij zagen verschrikt om. Zénobie stond tussen de goudgele bloemtakken, die zij openhield, met uitgestrekte hals en gretige ogen. $\mathrm{Zij}$ had zich door een onbehendige beweging verraden: zij stond hen af te luisteren.

- 'Gij kleine slang!' riep haar vader, en balde de vuist; maar zij was reeds tussen de heesters weggevlucht en uit hun oog verdwenen. Césarine gevoelde in deze stond een onoverwinbare afkeer voor het kind van haar zuster. 
Als zij thuiskwamen, was er een brief uit Den Haag voor Épuron: hij werd naar het Hof geroepen, en het werd afgesproken, dat hij 's anderdaagsmorgens, eer iemand van de familie op was, met de eerste trein zou vertrekken: eindelijk was het hem vergund het portret van de Koning der Nederlanden te maken. Dat was een heuglijke, een gelukkige tijding, - een schone dag was het geweest voor hem als mens en als kunstenaar!

Opnieuw verklaarde hij aan La Conque, dat hij zijn dochter beminde, en vroeg zijn toestemming in hun huwelijk. Deze zuchtte diep, maar waagde het niet meer opmerkingen te maken: hij vroeg enkel aan Césarine, of het ook haar wens was, en toen zij ja antwoordde, zei hij, dat hij er zich niet tegen verzette. Ook aan Éloi werd het nieuws aangekondigd. Deze sprak geen woord; maar een somber vuur gloeide in zijn ogen, en toen Marcel hem de hand toestak en zei: 'Wens mij geluk, Broeder', toen greep hij dezelfde, traagzaam, maar wrong hem ineens bijna de pols af, zodat Épuron een gil niet kon onderdrukken, en de krankzinnige schoklachte.

De kleine Zénobie was bij haar tehuiskomst dadelijk op haar kamer en in haar bed gevlucht, en had het deksel over haar hoofd getrokken. Zij wilde of dorst niet antwoorden, als Césarine bij haar ging. Épuron bekommerde zich geenszins over haar handelwijze. 'Het arme kind is zeker ijverzuchtig op uw genegenheid,' merkte de grootvader aan, en de anderen zwegen.

La Conque haalde een fles champagne om de verloving van zijn dochter te vieren, en schonk de glazen schuimend vol; maar het was een treurig feest; want de oude man had de verklaring van hun ontwerp voor een slecht nieuws aangezien. Césarine begon met weemoed aan de nakende scheiding van vader en broeder te denken, en Éloi was somberder dan ooit, en trok weldra zwijgend naar boven. Épuron alleen was opgeruimd; maar wat kan de vrolijkheid van een enkele in een kommervol gezelschap?

Zij gingen vroeg naar bed. Het meisje was vermoeid en sluimerde weldra in, nadat zij Zénobie goeden avond had gewenst, om te weten, of deze sliep; doch de kleine had niet geantwoord. In het midden van de nacht werd Césarine eensklaps wakker, en bij het weifelend licht van het nachtlampje, zag zij het kind doodbleek en starogend voor haar sponde staan. Zij scheen onder de invloed van een machtige angst of een zenuwachtige gejaagdheid.

'Tante Césarine,' sprak zij met moeite en afgebroken, 'gij moogt niet.'

- 'Wat mag ik niet?' vroeg deze met een hevige ontsteltenis, die zij trachtte te verbergen.

'Met Papa trouwen, Tante Césarine.'

- 'En waarom niet?' zei het meisje.

'Omdat hij u zou doden,' sprak het kind op doffe, bijna onverstaanbare toon.

- 'Bibi, gij droomt!' riep haar tante. 
'Hij heeft het met Mama ook gedaan,' hernam de kleine, deze schrikkelijke beschuldiging thans met kalme vastberadenheid uitbrengend.

Césarine huiverde: zij zag, dat het kind met overtuiging sprak, en hoopte nu misschien het geheim omtrent Julie op te klaren. Zénobie vertelde haar snikkend, dat Mama ineens was gestorven, nadat Papa haar te drinken had gegeven, als zij niet wel was, en dat zij uitgeroepen had: 'Épuron, gij hebt mij gedood, ik ben vergiftigd!' - 'Ik heb hem gehoord,' sprak Zénobie, 'want ik verstond de taal, die zij spraken evengoed als Frans.'

- 'Maar zij was zinneloos!' kreet Césarine, zich thans aan deze onderstelling als aan een laatste redmiddel vastklampend. 'Zij was zinneloos, Zénobie.'

'Zij was het niet,' klonk het beslissend antwoord.

-'Neen, zij was het niet,' dacht Césarine: haar vader had het haar gezegd, en Épuron had het bevestigd. - Maar als zij niet zinneloos was, dan moest Épuron een misdadiger zijn...!

En lang nadat de kleine in haar bed was teruggekeerd, bleef Césarine opzitten: zij drukte de handen op haar voorhoofd om de hevige gloed in haar hersens te stillen, en door kwelling en ontsteltenis overmand, viel zij eindelijk ontzenuwd achterover op haar peluw.

\section{$\mathbf{X}$}

Toen het helder zonlicht in haar kamer scheen, kwam de schrikkelijke openbaring van de nacht haar enkel nog als een bange droom voor. Épuron was vroeg vertrokken, en had haar een briefje van afscheid nagelaten. Zij nam het op en las de liefderijke woorden, die het behelsde, maar verfrommelde het aldra in haar hand: het zaad van de argwaan was in haar hart gestrooid en ontkiemde er op onrustbarende wijze.

Césarine trachtte opnieuw de kleine te ondervragen; maar deze begon bij het eerste woord daarover zo zenuwachtig te sidderen, dat haar tante verschrikt het onderwerp opgaf. Zij voelde een mengsel van medelijden en afgrijzen voor het kind, dat, zo jong nog, reeds aan zulke wrede folteringen ter prooi was. Zij verwierp de gedachte aan zijn schuld met verontwaardiging, en dacht weer aan hem met liefderijk betrouwen; maar toen zij zich zijn terugkomst voorstelde, schrikte zij onwillekeurig bij het vooruitzicht hem weer te zien. Des nachts rees soms een schrikwekkende gedaante voor haar geest: Julie in haar bed opzittend, met uitgestrekte arm en brekende ogen haar vreselijke beschuldiging tegen Épuron uitbrengend. 'Indien hij zich eens aan die misdaad had plichtig gemaakt, om mij te kunnen huwen?' en die onderstelling deed haar huiveren. Maar neen, zij geloofde niets van dit alles: Zénobie had het met haar zieke verbeelding en haar boze inborst gedroomd of verbloemd; maar tot wie zich wenden om opheldering? O! indien Julie zinneloos geweest was, dit zou alles verklaren, en thans wenste zij, wat haar eerst als het ergste was voorgekomen! 
La Conque had haar afgetrokkenheid en zenuwachtige overspanning genoeg opgemerkt, en in de overtuiging, dat het denkbeeld van de krankzinnigheid van haar zuster haar opnieuw begon te plagen, bracht hij zelf het gesprek op dit punt, en als Césarine hem wanhopig daarover weer ondervroeg, toen verzamelde de arme vader al zijn welsprekendheid om haar van het ongerijmde van haar vermoedens te overtuigen en haar onbarmhartig te folteren.

In die stemming vond haar Épuron, toen hij na enige tijd uit Den Haag terugkwam. Zij zat alleen in de duistere eetplaats en hij bemerkte in den eerste niet zozeer als later de volslagen verandering, welke in haar was gekomen.

Hij was zo blij daar weer te zijn; hij was zo tevreden over de uitslag van zijn reis, en gaf zijn vreugde op zulke kinderlijke wijze te kennen. Hij vertelde van zijn bijval bij de Koning, en haalde kleine grepen goudstukken uit de zak van zijn vest, waar hij ze met echte kunstenaarszorgeloosheid had bewaard, en wierp die gedurig schertsend van de rechter hand in de linker, die hij open en voor haar hield, 'daar, daar, nog al, Césarine,' lachte hij met onschuldige fierheid, terwijl de goudstukken op elkander klonken.

'Neen, die man had zich niets te verwijten,' dacht Césarine, en zij kon er niet toe besluiten haar voornemen ten uitvoer te brengen, en hem weer van Julie te spreken, en aldus zijn blijdschap te storen. En toen hij haar over de reden van haar neerslachtigheid ondervroeg, antwoordde zij ontwijkend, dat Éloi zo prikkelbaar geworden was, dat hij om een niets in toorn ontvlamde, en dat haar vader zo bekommerd scheen, en de gelukkige Épuron dacht daarbij, dat zij de waarheid niet zeggen wilde, maar dat zijn gerekte afwezigheid de grootste oorzaak van haar treurnis uitmaakte!

Zijn tegenwoordigheid verdreef allengs haar mistroostigheid, en toen zij zich te slapen legde, schoot de gedachte haar door het brein, hoe roekeloos het geweest ware een woord te laten vallen over de beschuldiging van Zénobie, dat kind, dat hij reeds zo weinig beminde, en hoe zij daardoor een eeuwige haat tussen vader en dochter had kunnen aanvuren! En zo denkend sliep zij in; maar de schaduwbeelden van de nacht verrezen allengs weer voor haar geest.

\section{XI}

Telkens Épuron haar aanspoorde om de dag van het huwelijk te bepalen, zag zij verschrikt op en zei: 'O, nu nog niet: neen, neen, Marcel, ik kan uw vrouw niet worden.'

- 'Maar gij hebt mij uw woord gegeven, Césarine, zoudt gij het terugnemen?' vroeg hij met een trek van ongenoegen op zijn aangezicht.

'Julie, Julie!' riep zij toen jammerend uit.

Hij had er reeds meermalen met La Conque over gesproken, en de gedachte geopperd, of wellicht Éloi haar brieven van Julie had meegedeeld; maar de vader verwierp deze mogelijkheid: in de brieven, die Éloi van zijn zuster 
bezat, verzekerde hij, was niets, dat haar op het spoor kon brengen; overigens zij dagtekenden van een tijd, toen Julie nog bij haar verstand was.

Épuron dacht en herdacht erover, en eens dat hij weer tevergeefs een bepaald antwoord van zijn verloofde had afgesmeekt, fluisterde hij La Conque in het oor - het was tegen de avond, juist boven de duistere trap, waar hij hem ontmoette - dat hij zich toch meende te herinneren, dat Julie op het laatst van haar leven nog geschreven had aan Éloi, en dat in die brief misschien...? hier trad hij plotselings een trap of twee lager: hij geloofde zijdelings iets te zien bewegen, en ontdekte Zénobie, die hem sluipend was gevolgd, en zich, om hem af te luisteren, in de donkere nis had verborgen. Hij schudde haar bij de schouder, en zij kromp sidderend ineen onder zijn ruwe hand: 'Wat doet gij daar, gij hatelijke toverheks?' riep hij toornig.

La Conque trachtte hem te bedaren, en hij liet haar los.

Zénobie had niet voor niet van die brieven van haar moeder gehoord: zij kende de plaats, waar deze lagen in de lessenaar, en wist, waar de sleutel verborgen was. In haar nieuwsgierig brein overwoog zij, hoe zij op Oom Éloi's kamer kon geraken, als hij er zich niet bevond, en reeds meer dan eens had zij aan zijn deur op loer gestaan en door het sleutelgat gekeken; maar wanneer zij daarbinnen iets hoorde bewegen, of dat hij kuchte, was zij weggevlucht; want zij vreesde Oom Éloi onuitsprekelijk. Ook de geruite gordijn speelde haar in het hoofd, en wat daarachter wel mocht verborgen zijn, prikkelde haar verbeelding.

Het duurde echter niet lang of de gelegenheid bood zich aan om haar plan ten uitvoer te brengen. Haar vader was naar een vrienden-avondfeest, en zou eerst laat in de nacht thuiskomen. Éloi had zich bij uitzondering aan de kaarttafel gezet met Césarine. Het was na het avondmaal, maar nog dag; want het was in het midden van de zomer. Onbemerkt trok de kleine naar boven: de sleutel stak op de deur, en schuw omziende, doch vastberaden, opende zij deze, en zag rond in de kamer: daar in de lessenaar lagen de brieven, en ginder in de hoek wuifde de geheimzinnige gordijn in de avondwind, die door het wijd open raam speelde. Zij aarzelde, in twijfel welke nieuwsgierigheid zij het eerst zou voldoen. Eindelijk, nog steeds naar de hoek starend, opende zij de lessenaar: daar lag het manuscript, waaraan Oom Éloi zo volhardend arbeidde, een groot pak, maar enkel losse papieren, en eer zij het had opgenomen om de brieven te zoeken, was de deur, die slechts aangetrokken was, in de tocht opengevlogen, en stoven de bladen in de kamer rond.

Onthutst wierp de kleine zich op de bodem en verzamelde er enige in aller ijl. Een enkel lag met een hoek onder de geruite gordijn: zij greep het ook, en op dit ogenblik kwam een nieuwe tocht, die de deur weer toewierp, de gordijn opblies en ineens deed overslaan, en Zénobie zag - o dodelijke schrik! - een groot mensengeraamte, dat aan een ijzeren staaf hing met lange knokenbenen en vooruitspringende ribben, met afhangend bekkeneel 
en met grijnzende tanden! - een geschenk, dat Éloi in de tijd van een professor van ontleedkunde had gekregen. - De gordijn had in het overvliegen een hand van het geraamte geraakt, en deze bewoog zich nog slingerend en ratelde tegen het ander gebeente. Haar knieën knikten onder haar, en haar hart hield op van kloppen: zij wilde vluchten of schreeuwen, maar zonk machteloos achterover met het pak volgeschreven bladen, dat zij krampachtig in de hand hield.

\section{XII}

Intussen zaten Éloi en Césarine aan de kaarttafel; het was een ruwe taak voor het meisje, bij wie de kwellingen van de argwaan en het zelfverwijt, dat erop volgde, zich folterend afwisselden, al haar aandacht aan iets zo onbeduidends te moeten wijden; maar Éloi beminde dit vermaak, hetwelk sedert het verblijf van Épuron onderbroken was.

Wat spel zij speelden, weet ik niet meer; maar Éloi verloor, hij verloor gestadig, ondanks de moeite, die zijn zuster aanwendde om hem te laten winnen. Het scheen, dat zijn geest thans te zeer verzwakt was om zijn spel te kunnen besturen: dit gevoelde hij wellicht onbepaald, en van slechte luim geraakte hij allengs in gramschap en wierp eindelijk zijn kaarten op de tafel met een verwensing, die Césarine niet wist, of zij haar of hemzelf gold, en liep de trappen op naar zijn kamer.

Hij vond Zénobie nog in zwijm. Hij zag de geopende lessenaar, en de verstrooide bladen van zijn kostbaar handschrift, en het gedeelte ervan, dat het kind nog tussen de vingertjes hield. Hij schudde haar zo hevig dat zij de ogen opende en verdwaasd rondblikte, eer zij scheen te begrijpen, wat er gebeurd was.

'Wie heeft u hier gezonden?' bulderde hij met verkropte woede.

De woorden van die vraag fluisterden haar een rampzalige inval in, en om zijn toorn af te leiden en uit zijn handen te geraken, antwoordde zij met een van schrik versmoorde stem: 'Papa! O! sla mij niet, Oom Éloi!'

Hij deed haar geen leed, maar sleurde haar uit de kamer, na haar het pak uit de hand getrokken te hebben, en sloot de deur. Zij hield zich aan de muren vast om de trap te zoeken, en hoorde hem vervaarlijk razen en tieren daarbinnen: 'Épuron, Épuron,' herhaalde hij woedend, 'wat! hij komt mij niet alleen mijn zusters roven, maar mijn handschrift, mijn ontdekking, de kwadratuur van de cirkel, de altijddurende beweging, mijn roem en de onsterfelijkheid van mijn naam! Maar, ellendige! gij zult het mij betalen!' en toen lachte hij wild en ijzingwekkend.

Met een uiterste krachtinspanning bereikte het kind wankelend haar slaapkamer, en kroop in haar bed, dat altijd haar toevlucht was.

Laat in de avond hoorde zij iemand omzichtig de trappen van de derde verdieping afdalen en naar beneden trekken: dat moest Oom Éloi zijn; want 
hij alleen sliep ginder, en kort daarop scheen het haar, dat de voordeur open- en toeging. Zij hoorde de bange ademhaling van Tante Césarine, maar waagde het niet haar te wekken, om haar dit vermoeden mee te delen: zij vreesde Oom Éloi in al zijn woede.

\section{XIII}

Het kon omstreeks drie uur van de morgen zijn, toen een groot rumoer en gebel eerst de dienstmeid en aldra ook al de huisgenoten kwam wekken. Er stonden vreemde mannen en een nachtwaker aan de voordeur, en er werd een lijk binnengebracht. Een doek lag over het aangezicht. Césarine, op het gerucht benedengekomen, zag verstomd van schrik naar de onbekende gestalte met de natte beslijkte klederen, en de gedachte aan Épuron sneed haar vlijmend door het hart. La Conque trok de doek af, en erkende jammerend, in het bleke morgenlicht, het levenloos gelaat van zijn schoonzoon. Césarine wendde sidderend het hoofd van dit ijselijke schouwspel af.

'Maar wat is er gebeurd?' snikte la Conque. Het werd hem verteld met menigvuldige afgebroken woorden, en het kwam eindelijk hierop uit: De waker had op Bachterlei, omtrent twaalf uur van de nacht, een man achter zich over de Minnemeersbrug horen komen; daarop had hij zijn gang vertraagd, luisterend naar de naderende stappen, toen hij opeens iets als een schielijke aanval, gevolgd van een korte worsteling hoorde, daarna een gil en een plons in het water. Hij was toegesneld: hij ontwaarde niets meer en had ook niemand zien vluchten. Hij hoorde enkel nog het water, dat als altijd tegen de brug aanklotste. Hij had om hulp geroepen en de bruggedraaier opgeklopt; het was duister: zij hadden gezocht met de lantaarn, en de bruggedraaier was heel gekleed in het water gesprongen, en had na oneindige moeite en vele vruchteloze pogingen deze heer bovengehaald: hij leefde niet meer. Hij moest achterover in het water en op een paal of steen gevallen zijn; want hij had een diepe wonde in het achterhoofd. Het moest een kloeke kerel geweest zijn, die hem onverhoeds vastgegrepen en over de leuning van de brug had geworpen.

La Conque was in radeloze verslagenheid, en trok zich de haren uit het hoofd. Césarine stond roerloos als een beeld in het vernietigend bewustzijn, dat het laatste, het schrikkelijkste thans was gekomen. Zij gaf geen acht op de kleine Zénobie, die in haar hemd en op haar blote voetjes uit het bed was gekomen, en wenend haar knieën hield omstrengeld.

De waker overreikte aan La Conque het gouden uurwerk met de ketting, een pennemes met zilveren hecht en enkele andere voorwerpen, die hij aan de verdronkene had ontnomen. Er was een brief bij: de brief uit Den Haag, die hem zijn adres had gewezen.

'Maar wie toch,' vroeg La Conque, als tot zichzelf, 'wie toch mag hem afgewacht en aangerand hebben?' 
- 'Oom Éloi!' riep Zénobie wanhopig.

'Wat weet gij van Oom Éloi?' vroeg haar angstige grootvader.

- 'Niets, niets!' zei het kind. Zij wachtte zich wel te vertellen, wat toneel in de vooravond tussen hem en haar had plaatsgehad.

Men ging naar zijn kamer: in zijn bed was niet geslapen. In het studeervertrek was hij ook niet.

'Éloi, Éloi, mijn zoon, waar is hij?' kreet de vader, 'en gij, mijn arm kind,' hernam hij, en sloeg zijn arm om de schouder van Césarine. Zij liet het hoofd in overstelpte smart aan zijn hart zinken: 'O Vader,' zei zij somber naar hem opziende, 'ik zou toch nooit die man gehuwd hebben!'

- 'Gij liefderijke dochter,' sprak La Conque, die in deze woorden een blijk van kinderlijke verkleefdheid meende te ontdekken.

Des anderdaags werd Éloi van onder de brug gehaald, waar hij zich na de misdaad had verborgen, en waar hij als gevoelloos ineengekrompen zat. Hij kende niemand meer, maar werd woedend, toen hij Zénobie zag, en als men de naam van Épuron uitsprak, balde hij nog dreigend de vuist en sprak met zelf tevredenheid: 'Hij heeft het betaald, de ellendeling!'

Hij werd in een gesticht van krankzinnigen opgesloten.

Het hoge, smalle huis is sedert lang onbewoond: de deur gaat nooit meer open; de ruiten van de waaier en de vensterramen werden door de straatjongens uitgeslagen, en grote zwartbestoven spinnewebben wuiven van onder het dak. De geburen weten er niets anders van dan dat daarbinnen iets schrikkelijks gebeurd is, en dat de lieden, die dit huis bewoond hebben, naar een ander land zijn getrokken; maar de oude schoenlapper, die op de hoek in het keldertje woont, zou er wel iets meer van kunnen vertellen; want hij is het, die het lijk van de ongelukkige Épuron naar huis heeft helpen dragen.

Januari, 1875 


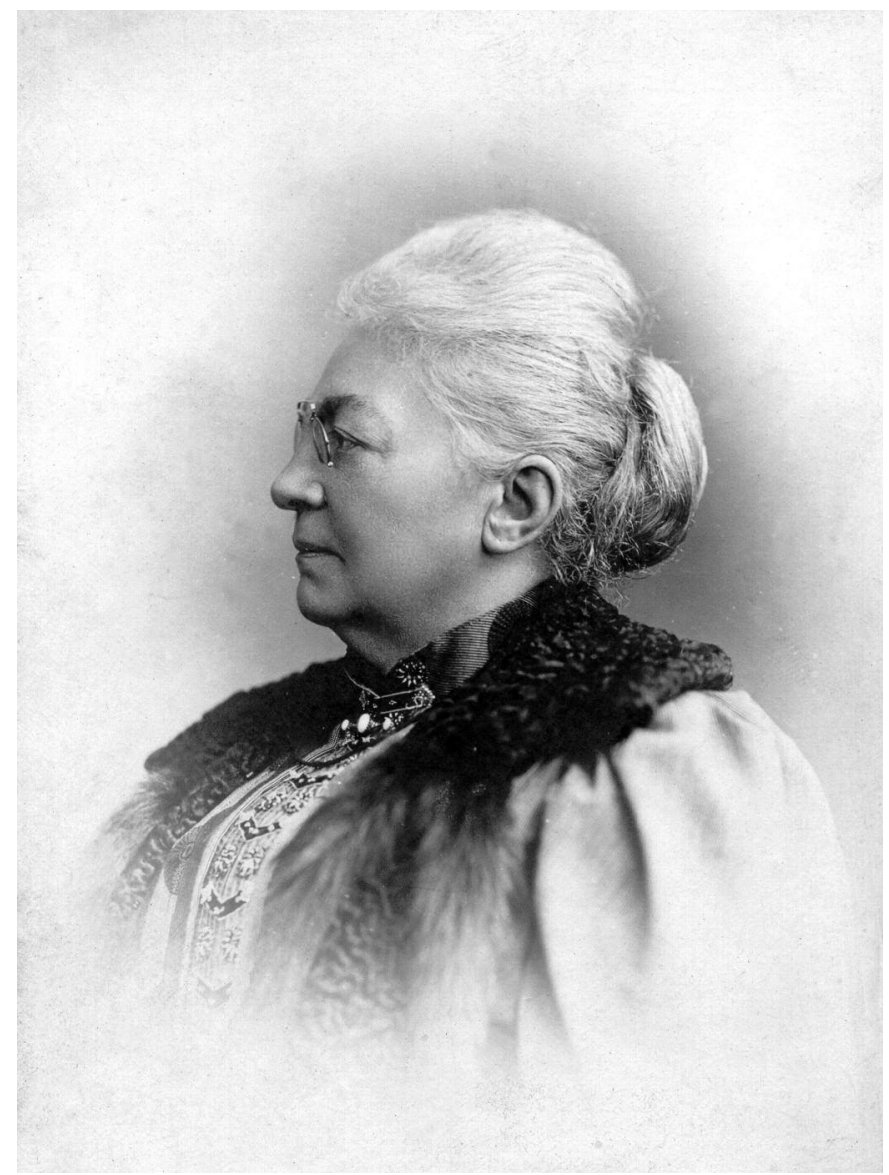




\section{MeESTERSCHAP}

Ja, 't was een mooi hofstedeken, dat van de gebroeders Velghe, het mooiste van geheel Vroden; het was er een om te schilderen, met zijn ongelijk hoge strooien daken en afdaken, zijn witgekalkte muren en de groengeverfde ramen. Bijzonder in 't voorjaar streelde het de blik en deed het de wens ontstaan: 'Hier zou ik willen wonen!' De boomgaard scheen een reuzenbloementuil, waarvan de knoestige, rechte of schuine stammen de stengels vormden, en waaronder het huisje bedolven lag in 't midden van zijn groen grastapijt, op open plaatsen met madeliefjes overdekt. Een grote beek omslingerde half het erfje en een klein, gans recht vlietje sneed het andere gedeelte af, zodat het wat hoger dan 't omgevend akkerland, als op een schiereilandje lag. De grote beek rimpelde nauw haar stil vooruitbewegend water, terwijl het kleine stroompje kabbelend en bobbelend in liefderijke overijling naar haar toeliep. Zwaluwen nestelden onder de kornis; ${ }^{1}$ vinken sloegen er in de appelbomen en over de beek lag er een bosje van heesterhout, beschaduwd door enkele hoge abelen ${ }^{2}$ met neerhangende takken en witblikkerende zilverschors. En tot overmaat van voordeel was het, schoon afgezonderd van elke andere woonstede, dicht bij het bebouwde dorp gelegen, zo dicht, dat men er het uur op de toren hoorde slaan, en de krassende kauwkens rondom de klokgaten vliegen zag. Geen vuile, onbruikbare landstraten daarheen bij avondstond of vroege wintermorgen. Het bruggetje over, enige honderden stappen langs de bochtige zoom van de beek, een eindje weg tussen twee hagen, de hoek van de smidse om en men was er, op de plaats zelf, bij de winkels, bij de kerk!

Sinds onheugelijke tijden was dat hoevetje bewoond door de familie Velghe. Na de dood van de ouders heette het er bij de 'kinderen Velghe', hoewel die zogezegde kinderen zelf reeds bejaard waren; en later nog, veel later, werd het de 'gebroeders Velghe', nadat de oudste zuster, Zalia (1), gestorven was. Dit was niet zeer lang geleden: haar graf van ongehuwde prijkte nog met de kroon van zuiverheid, waarin een papieren Heilige Geest hing, en de wind suizelde er nog door de vergrauwde en half afgewaaide en afgeregende kladdergoudsnippers, ${ }^{3}$ die de omheinende stokken versierd hadden.

De oudste broer, die de baas was en alles bestierde, heette Boudewijn, wat verkortingshalve in Bouwen veranderd was. De tweede droeg de naam van Karel, in Sarelken ontaard. Deze was zeer klein van gestalte, dwaas, braaf en onbekwaam als landbouwer. Sarelken wachtte de koeien in de zomer, en

(1) Rosalia. 
schilde aardappelen voor de huisgenoten of stekte rapen voor het vee bij winterdag. Bouwen was wijs, armmeester ${ }^{4}$ en maakte deel uit van de kerkraad. Hij ging met een schaal rond gedurende de goddelijke diensten en geen kon deftiger dan hij de muntstukken klinkend doen opslaan, en trouwhartiger het: 'God zal 't u lonen! God zal 't u lonen!' herhalen.

De gebroeders Velghe waren niet overpacht en in welstand en hadden de naam, dat ze zich niet te kort deden. Hun gebruik was niet groot, slechts drie koeien 'gingen er uit', zoals men 't noemt; het werkvolk was er gaarne en moest niet, zoals 't bij vele boeren gebeurt, door verplichtingen van huuraar ${ }^{5}$ zijn, of om karnemelk te krijgen gedwongen worden er het vereist landwerk te verrichten.

'De Velghen zijn geen beesten,' werd er als hoogste lof van hen gezegd.

En als lentegroei en zonnestraal en toekomsthoop was er nog in dit huis van ouderdom en vreedzame eentonigheid een kind, een meisje. En evenals het hoevetje bekoorlijk en verlokkend schoon heette, zo was ook zij een bevallige verschijning: neen, zo 'boos' (1), zo vrolijk en zo braaf was er geen, zei Bouwen bij gelegenheid. Hij noemde haar 'zijn rechter arm,' hij noemde haar 'de keppe' en 'de knuist,' ${ }^{\text {' }}$ alle boerse betitelingen van ingenomenheid en vaderlijke liefde.

'Wat zouden wij doen zonder ons Trezeken!' zei hij bijwijlen.

Zij was thans volwassen en 'fel' als een oude boerin; voor de kelder zocht zij haars gelijke; ' en aan wat anders dan aan haar zorg - het warm eten en vooral het warm slapen van de kippen - was het te wijten, dat zij in 't midden van de winter, als het vroor dat het klonk, alle weken met verse eieren op de markt stond dan? Wat zegt ge daarvan? en dat ze het hoogste van de markt, ja soms een stuiver boven de markt voor haar boter kreeg? De banden van haar karn blonken als goud en haar akers schoten vonken in de morgenzon. Nooit moest men ze vermanen voor het werk. Nooit sprak ze tegen.

Tegenspreken! dat zou Bouwen niet geduld hebben. Hij handhaafde zijn meesterschap: 'Laat $\mathrm{u}$ in de hoek niet zetten. - Ontkleed $\mathrm{u}$ niet, voordat ge slapen gaat,' dat waren leuzen, die hij van zijn ouders had geleerd en levensregels, waarnaar hij zich richtte.

Trezeken was het kleinkind van een ongehuwde zuster. Zij zelf was nooit door een vader erkend. Haar moeder en haar grootmoeder waren dood; haar oudooms hadden ze als hun dochter in huis genomen, toen ze nog zeer klein was en Bouwen er behagen in vond haar tussen zijn knieën te nemen en te zingen:

Te avond in den avond, als 't maantje schijnt,

Het hondje dat zal springen,

Het katje dat zal zingen,

En Trezeken, mijn bezeken, zal speelman zijn!

(1) Arbeidzaam, vlijtig. 
Het kind had geen gezellinnen, geen omgang dan met de oude jonkmans. Sarelken sneed haar een fluit uit de afgehakte twijgen van de linde, die aan 't hofgat stond en Trezeken zag toe, hoe gemakkelijk de sappige bast losging, en voelde met genot het vochtig-fris-gladde houtstokje tussen haar vingertjes. Toen floot ze erop bestendig, onvermoeibaar: 'Om iemand horendul (1) te doen worden,' zei onkel Bouwen, een zinspeling makend op het schel gefluit, dat zijn oren verscheurde.

Later ging zij school in 't dorpsklooster. Thans had ze speelmakkertjes en bij het terugkeren speet het haar telkens, dat zij altijd de eerste van de troep scheiden moest aan haar hofje.

\section{II}

Trezeken was twintig jaar. De oudste der ooms was fier op haar, en Sarelken zelf keek haar soms met verwondering aan, als deed hij de ontdekking van iets nieuws, iets kostbaar-zeldzaams in hun woning; en onbepaald kreeg hij tevens een vermaning van gevaar, dat hen omzweefde, een benauwdheid of een voorgevoel van bedreigde vrede, dat in zijn eng brein tot geen duidelijkheid komen kon, maar hem verontrustte.

En wat Sarelken te bekrompen was om uit te vinden, vormde zich helder tot vrees in het gemoed van Bouwen: 'Tot nu toe is ze wijs en braaf; als ze maar 't hoofd niet in het wilde steekt, als er maar geen vrijers komen!'

'Ge moet ze kort houden,' kreeg hij voor raad. Zulks deed hij ook, zijn nichtje bij gelegenheid de les lezend: 'De beste paarden worden op stal bezocht,' in de hoop dat het hier niet aldus zou toegaan, en de voor hen onmisbare meid door haar lotsbestemming niet opgeëist zou worden.

En het geschiedde toch, het paardje werd op stal bezocht, en misschien was de stal zelf wel voor iets in de magneetkracht, die er velen tot haar trok.

Felix Landuit was de verkorene.

Het duurde reeds geruime tijd, voordat de ooms het wisten. Sarelken was te simpel om zich af te vragen, waarom de beide jongelieden eerst des zondags samen van de vespers ${ }^{8}$ kwamen, en geruime tijd aan 't hofgat bleven praten; waarom Felix Landuit wat later binnentrad om zijn pijp aan te steken, en toen het winter werd soms uren lang in de hoek, onder de schoorsteen bleef zitten, terwijl Sarelken de beesten ging geven' of 'loof' (rapen) haalde. Bouwen zat des zondags in 't Gemeentehuis, waar hij met de kaart speelde tot het uur van 't avondmaal, en toen was de bezoeker reeds vertrokken. Sarelken had het zeker dadelijk vergeten of dacht er niet meer aan, althans hij sprak er zijn broer niet over.

Maar dat verkeer met Feel scheen Trezeken nog minzamer voor haar ooms te stemmen; het was alsof de liefde tot de ene haar hart verruimde in

(1) Wordt gezegd van woedend horenvee. 
plaats van het voor anderen te sluiten. Bouwen vond des zondagsavonds zijn klompen gewarmd staan, zijn pijp met de tabaksblaas gereed op de tafel liggen; een groot stuk spek of worst voor hem afgesneden; een zoet: 'welkom' wachtte hem van op de drempel.

'Feel is geen dwaze,' zeiden de mensen, 'hij zoekt om er in te trouwen' (1).

'Introuwen, introuwen!' sprak Boudewijn, toen het verkeer hem eindelijk ter oor was gekomen. 'Neen, duizendmaal neen, zolang dit op dat staat niet,' en hij wees zijn hoofd en zijn schouders aan.

Hij viel als uit de lucht, hij die gemeend had, dat een mooi jong meisje geen andere zielsbehoeften bezat dan om naar de kerk te gaan, en wier hart geen andere belangstelling kende dan de kippen graan toe te werpen en de koeien te melken!

'Ik mij mijn meesterschap laten ontnemen, nooit, nooit!' herhaalde hij. Doch thans had Feel zich verstout. Hij kwam er ook toen Bouwen thuis was, hij zat er weldra bijna elke avond en gans de avond.

Hij speelde smousjas ${ }^{10}$ met Bouwen, terwijl Sarelken verdwaasd toezag, en Trezeken de klederen van de oudooms verstelde of naarstig ander naaiwerk deed, altijd nederig, altijd behulpzaam, als een dienst werd vereist. Bouwen sprak over zijn landbouwaangelegenheden met Felix, raadpleegde hem over het kopen van een koe, over de tijd voor 't slachten van het zwijn; en het was Felix die zich dit jaar belastte met het betalen der contributiën, zodra de elderswonende ontvanger te Vroden zitdag hield. Hij was 't ook die de oude man waarschuwde, toen de 'ijker' (controleur van maten en gewichten) in 't Gemeentehuis zetelde en hij zelf was 't die er met de te onderzoeken voorwerpen naartoe trok.

\section{III}

Eens zei hem Feel met een verlegen glimlach, terwijl hij zijn opgenomen kaarten door malkander ${ }^{11}$ schoof en weer neerlegde:

'Bouwen, ik zou u een woordje willen spreken.' Dit is gewoonlijk de voorrede tot iets gewichtigs.

'Ik luister,' antwoordde de man gevat.

'Gij weet toch wel, dat ik bij Trezeken ga (2), nietwaar?'

'Ik heb het gelijk menen te bemerken,' zei Bouwen ontwijkend.

'En van verkeren komt gewoonlijk trouwen,' hernam Feel, die zijn beschroomdheid overwonnen had, geniepig, de toegesprokene van onderop beziende, terwijl Trezeken, zeer rood, dieper over haar werk boog en koortsig gauw voortnaaide.

De oude man verschrok, met open mond en starende ogen:

(1) Blijven wonen bij de huisgenoten van een der echtelieden.

(2) Trezeken vrij. 
'Ge wilt toch niet zeggen zeker...?'

Sarelken zat luisterend te glimlachen.

'Ik wil maar zeggen, Bouwen, dat een mens toch niet eeuwig jong blijft. Wij hebben er al lang van gesproken in 't groot gilde te gaan, ${ }^{, 2}$ glimlachte nu ook Feel.

Daar viel de slag, des te treffender omdat hij onverwacht was. Bouwen had in vertrouwvolle roekeloosheid voortgeleefd; dat verkeer scheen een duurzaam ingerichte toestand geworden, wie zou er nu verandering verwachten!

Trouwen! Trezeken trouwen, weggaan van hem, van Sarelken, van het hoeveken verdwijnen, de beesten verlaten, de kippen, de melkkelder! En hij keek rond naar het rein gepijpt ${ }^{13}$ schoorsteenkleed, naar de ouderwetse borden op het rek, naar de glimmende kuipbanden, door haar hand geschuurd; naar de rode vloer... En het was alsof een wrede klauw zich op zijn hart had geslagen om er een deel van los te scheuren. Zijn kind, zijn knuist...!

'Ge zoudt mij toch niet verlaten zeker?' in doodsangst richtte hij zich tot haar.

Trezeken begon te schreien en stotterde door haar snikken heen, Feel aanwijzend:

't Is hij, die mij met rust niet laat, ik heb gezegd, dat ik niet wilde.'

'Er zou maar dat meer aan mankeren, ${ }^{14}$ meende Sarelken hoofdschuddend.

'En waar zoudt ge naar toe gaan, wat zoudt ge aanvangen?' vroeg Bouwen praktisch.

'We zouden ten onzent introuwen,' zei Felix.

'Introuwen!' dat woord, dat hem zo menigeen had onheilspellend in het oor doen klinken als 't geratel van een naderend onweer, een stormloop tegen zijn meesterschap, dat woord verschrikte hem nu als een dreigement van verlatenheid, vereenzaming en ondergang.

'En ge zoudt elders gaan zoeken, wat ge hier met de voeten trapt? en ik zou een meid moeten huren? op mijn leeftijd, - bedenk: ik ben al op mijn zesenzeventigste!' en hij legde een nadruk van gewichtig wee op het cijfer 'op mijn leeftijd zou ik mij aan andere gezichten moeten gaan gewennen...!'

Oom Bouwen stelde 't op een schreien, van dat schreien zonder tranen, aan oude lieden eigen, en dat zulk een indruk van machteloze, wanhoopvolle smart op de aanhoorders maakt.

'Ik zal u niet verlaten, oom,' zei Trezeken, bewogen, 'en daarmee is het uit.' Sprak zij in ernst en roekeloos? Had zijn vrees haar hart vermurwd en haar oprecht grote kinderlijke verkleefdheid voor hem en Sarelken opgewekt, en moedig elk ander vooruitzicht achteraangezet? of lag er onder de onbewuste sluwheid van haar onschuld een heimelijk gevoel van oppermacht, een vertrouwvolle zekerheid, dat haar verzaken enkel schijn en de eindzegepraal toch de hare was?

Wie kan het zeggen! Wie kent de vele plooien van het menselijk gemoed en kan ze ontvouwen? 
Enige dagen verliepen zonder de komst van Felix, in steeds werkzame stilzwijgendheid, geen woord meer over het gesprek; maar er hing een onrust over het huis, er broeide iets in de omgeving, een wachtende zwoelheid als van naderende storm, in twijfel nog of de dreigende vlaag, zo zwart en rossig-onheilspellend, ginds van achter 't vreedzaam groene bogerdloof opkomend, in hagel en met bliksem los zal breken, of - als noodzakelijke en onvermijdelijke verkwikkingsbui - in zacht gedroppel neer zal komen...

\section{IV}

Ootmoediger dan ooit deed Trezeken haar werk, wachtte aan de tafel tot de beide bejaarde mannen zich bediend hadden; at de oude korst als er vers brood gebakken was, en liet niet na een suikerklontje - ongehoorde weelde in een boerenhuis - bij hun 'spoelkom' - koffiekopje - na het eten neer te leggen. Zijzelf vergenoegde zich met een slokje, staande, in allerhaast.

Zij kende de tijd, waarop tweemaal in 't jaar - mei en november - oom Bouwen zich geregeld in zijn slaapkamer, waar hij anders nooit bij 'lichten dage' de voet stelde, terugtrok in geheimzinnige afzondering. Zij hoorde hem het roestig slot van zijn koffer openen, nadat hij langs binnen de deurgrendel had ingeschoven; een gereutel van ontplooid papier, zo onvatbaar gewaand en toch zo duidelijk verneembaar, ruiste tot in de keuken, tenminste tot aan het sleutelgat, waar zij het oor leende. Oom had een schaar gevraagd en Trezeken glimlachte: hij meende zeker dat ze het niet wist! Hij sneed zijn 'papierkens' af, morgen of overmorgen zou hij opgeven voor zaken naar de stad te moeten gaan. Het was om de $\operatorname{kroos}^{15}$ van zijn acties.

De oude boer was zeer verholen in zake van geldkwesties en eigendomsbezit. Zelfs Sarelken, die recht had op de helft, wist niets van zijn persoonlijk fortuin - tenminste van het vooruitgaan ervan. Het was ook niet om zijn broer te bedriegen of hem in iets te kort te doen, dat Bouwen dit alles verheimlijkte, het was uit een aangeboren zucht naar mysterie, dat hij met vele, zoniet alle landlieden eigen had. Het was de handhaving van zijn meesterschap als hoofd van 't huis, als pachter van het hoeveken. Op hem alleen berustte al de verantwoordelijkheid, ofschoon de huurceel op de beide broers sprak.

Geen cent verteerde hij ervan; zodra de toch altijd betrekkelijk kleine som groot genoeg was, werd er een nieuw effect bij gekocht en onverwijld even zorgvuldig verdoken als al het overige.

Dit zou eenmaal voor Trezeken zijn.

Maar de toekomstige en wellicht onbewust hoopvolle bezitster van dit alles, was gevat of bescheiden genoeg om geen nieuwsgierigheid te laten blijken, geen belangstelling te verraden, geen vraag te stellen.

'Morgen zal ik naar Gent gaan,' berichtte hij eenvoudig.

'Ja, onkel, wanneer?' 
Liefst zou hij de eerste trein hebben genomen, maar het bureel van de wisselaar, dat wist hij, was zo vroeg niet open.

'Met de trein van half tien.'

En Trezeken zorgde dat hij een goed stuk spek of een eind gedroogde worst bij zijn ontbijt had.

Hij kwam uit zijn kamer in staatsiegewaad, zoals hij in de kerk met de schaal rondging, net, in 't zwart grof laken, met een hoge hoed op, een die hij sinds meer dan twintig jaren met dezelfde zuinige zorg behandelde. Uit gewoonte nam hij zijn regenscherm, hoe helder ook het weer mocht wezen, en toen Fik, zijn huishondje, dat hem altijd en overal vergezelde, kwispelstaartend opsprong en hem - nog twijfelend - vragend in de ogen keek, had Bouwen enkel zijn kerkboek van de schoorsteenplaat te nemen en hem voor te houden:

'Thuisblijven,' heette dat.

Fik liet zijn opgespitste oren en zijn korte staart hangen, een schaduw verduisterde zijn wakker oog en hij kroop onder de tafel, wel wetend, dat het vonnis onherroepelijk was.

Bij het terugkeren van oom Bouwen greep dezelfde sluike handeling plaats: hij sloot zich in zijn kamer op; het kofferdeksel werd schier geruchtloos gelicht en viel even geruchtloos toe; soms klonk er een bescheiden goud- of zwaardere zilvertoon tot in de keuken door, en de stilte legde zich weer op de schat.

Oom Bouwen verscheen opnieuw in weekdracht, met een uitdrukking van verhoogde tevredenheid op het tanig gelaat, en Fik mocht mee naar de akker of de stal. Fik volgde hem steeds op de hielen: wild en uitgelaten, als de weg verre leidde, fatsoenlijk en traag, als zijn meester enkel het zwijnshok opende, waar hij wijsgerig toezag naar de gevette, zwaar grollende dieren, of - ineens zijn hondennatuur volgend - onweerstaanbaar, ondanks geleerde tucht, de zeug met haar rozengolven van biggetjes om zich, ondeugend aanblafte. Zijn straf was het dreigement van een schop - tot de schop zelf vanwege oom Bouwen kwam het nooit.

Als Trezeken de kippen eten toegooide, met: 'Ti, ti, ti!' en heel de schaar van pluimgedierte van achter de schuur, de houtmijt en van op de mesthoop kakelend toeschoot, maakte Fik zich soms aan dezelfde euveldaad schuldig. Hij sprong er jagend tussen, zodat de bende uiteenstoof.

Trezeken lachte, half boos tevens:

'Die wildvang, die stouterik! allé, hier!' maar Fik luisterde niet of weinig.

Hij trad in 't water achter de eenden, terwijl zij het toegeworpen brood opslokten en blafte ze aan, tot ze wegzwommen.

Barbaar sloeg lusteloos dit schouwspel gade, Barbaar, de grote kettinghond, lamlendig uit zijn gemetseld hok op het erf kruipend, met zijn ruige huid en zijn kwade uitdrukking, wellicht met een gevoel van nijd of een bewustheid van 't verschil der standen, in het weegevoel van ongelijk verdeelde levensgift. 
De zondag kwam. Trezeken ging naar de vesper als naar gewoonte; Sarelken was insgelijks naar de kerkelijke dienst, vanwaar hij de zogenoemde 'peetjes (oude mannen) herberg', - een vergadering van het genootschap van Franciscus-Xaverius in 't nonnenklooster zou bezoeken. Dat was zijn enige wekelijkse uitspanning, Boudewijn wachtte thuis, het hof mocht immers niet alleen wezen. Hij was niet zeer opgeruimd Bouwen, zelfs wat onrustig, zijn gemoedsvrede was verstoord. Wat moest die Feel Trezeken nalopen, van trouwen komen spreken, alsof ze daar niet content was! Trouwen, was zo iets nodig? Hij zelf was wel niet getrouwd. Hij zat dubbend aan de haard, waarvan de blijde houtlaai hem gezelschap hield in zijn hoek, die ereplaats, in zijn houten zetel, die troon van 't hoofd des huizes op een boerenhoeve. Fik nevens hem, zeer dichtbij om zijn meester niet alleen te zien en daar te weten, maar ook nog te voelen.

En de grijsaard keek uit het lage vensterraam naar de boomgaard, die nog naakt stond, maar waar het gras reeds groende, o zo fris als het doet onder de vers gesmolten sneeuw.

Gedurende de week was't weer slecht geweest. Op Lichtmis had men een geweldige sneeuwstorm gehad net als in 't putje van de winter. Hij zou die dag nooit vergeten, niet om de storm, maar om iets anders, dat ermee in verbinding stond: denk eens, Trezeken was omtrent de middag uit de stal over't hof gekomen, worstelend tegen de wind, gans wit van de sneeuw, met haar borstdoek en haar voorschoot over 't hoofd gewaaid; de voordeur met een ruk in de orkaan achter haar toeslaande, en zij had hem iets getoond, daar op diezelfde plaats, waar hij zat. Zij had hem in de korf, die ze vasthield, doen kijken: 'Onkel Bouwen, zoveel eieren als wij hennen hebben! twintig!' had ze gezeid met zachte glans van zelfvoldoening op 't gelaat. 'Zij hebben alle gelegd!'

Hij kon het schier niet aannemen, zoveel ineens, in zulk een storm, zo vroeg op 't jaar!

'Wel meisje toch!'

En die kleinigheid had hem blij gestemd, ook nog voor iets anders. Trezeken had zo stilzwijgend, nadenkend haar werk gedaan, dat hij zich meer dan eens had afgevraagd of zij ook pruilen kon, of dat ze groot verdriet had; en nu keek ze zo wakker-vrolijk op, bij het tentoonspreiden van zulk een schat, en de oude man was tevreden, omdat hij haar zo liefhad!

Indien Feel maar voorgoed wilde achterblijven! ${ }^{16}$

Er scheen niet heel veel hoop op te bestaan, want daar zag hij de beiden tezamen aan het hofhek. Zij hadden zoveel te vertellen, dat ze er nog bleven dralen, schoon de schemering reeds begon in te vallen. Bedenkelijk zag Bouwen haar het hoofd schudden; zij scheen Feels dringende woorden te weerleggen, scheen hem iets te weigeren, dan glimlachte zij weer als bij 't visioen van iets aanlokkelijks... 
Mooi was ze, dacht oom Bouwen: groot, zwart van haar, met donkere ogen, wat bleek, het was jammer, dat ze niet wat 'opdragender' van kleur was. Dat het ovaal van haar aangezicht in zijn zuivere volle lijnen, en juist die marmerachtige kleur een kunstenaar geestdriftig aan een antiek beeld zou herinnerd hebben, dacht hij niet, kon hij niet denken, daar op 't afgezonderd goedje. Feel was een flinke kerel, kloek, rood van blos, vlug van voorkomen, hij was bij den troep ${ }^{17}$ geweest, men kan ze alle herkennen, een felle op 't land. Hij had ook een kleine fout, die de evenaar met Trezekens blankheid uitmaakte, hij was 'wortelgrijs' (1) van baard en haren, doch: 'wie is er volmaakt op aarde?' dacht wijselijk onkel Bouwen.

Maar wat hadden zij om den duivel aan elkander te vertellen? De oude man stelde zijn eisen al hoger en hoger. Trezeken had hem immers beloofd bij hem te blijven, waarom zag ze dan ineens van Feel niet af? Wat betaamde dat achternageloop, als er toch geen huwelijk van komen zou? Hij wond zichzelf al meer en meer op, Bouwen, die de macht der liefde nooit had gekend. Het maakte hem bepaald korzelig, die beiden daar te zien staan. De varkens moesten (hun eten) gegeven worden, de koeien gemolken...! hij schudde het hoofd met een sterk besef van verongelijking. Met geweld stampte hij de blokken brandhout, half opgeteerd, geheel aan stukken door middel van de blaaspijp, dat de vonken in een schitterend starrenheer ${ }^{18}$ door elkander wemelend, de schoorsteen invlogen. De kat, die met de rug ronkend ${ }^{19}$ tegen zijn benen wreef en niets misdeed, kreeg een schop: 'Allè, luie vod!'

De duisternis begon in te schemeren, toen Trezeken stil als een muisje binnentrad zonder Felix.

'Zijt ge daar eindelijk?' zei oom Bouwen stroef, 'het begon mij, verdoemd! te vervelen, weet ge.'

Het was de eerste maal van haar leven, dat hij haar aldus toesprak en zij schrikte letterlijk van het woord en de toon.

Zij deed haar mantel af, ging in haar slaapkamer, en Bouwen, wiens gehoor nog niet verzwakt was, wist aan 't herhaalde snuiten van haar neus, dat ze hevig schreien moest. Hij was wat haastig geweest, het speet hem nu. Trezeken kwam binnen met dikgezwollen, rode oogleden, het hoofd terzijde uit 't licht van 't aangestoken lampje houdend, opdat hij het niet zien zou, wat hem heel vermurwde: 'Braaf kind toch!' zei zijn hart, al wilde nog zijn mond geen schuld bekennen.

\section{VI}

Maar een nieuw verdriet wachtte hem diezelfde avond, een onverwacht, nooit gedroomd, verbazend iets. Sarelken kwam dronken thuis, zwenkend, strijdlustig, vloekend en tempeestend, Sarelken, zo godvruchtig, zo lijdzaam

(1) Rossig blond. 
en... zo dwaas! Sarelken had het spraakvermogen en zijn zelfstandigheid weergekregen onder de prikkel van het geestrijk vocht.

Stout kwam het steeds zo schuchter ventje op zijn meester en gebieder af: 'Asa, broer, hoe zit het hier? Waar is ons geld? ik heb hier recht op evenveel als gij, ik wil mijn "part” hebben.'

'Uw part!' zei Bouwen ontzet en verwonderd, als ware een deel van de hemel voor zijn voeten gevallen. 'Uw part, om wat te doen?'

'Om te doen wat ik wil, wat ik weet en wat ik u niet zeggen zal,' antwoordde Sarelken met een grove godslastering.

'Wat zullen wij nogal horen, wat zullen wij nogal beleven!' jammerde Bouwen, en dan:

'Ga naar uw bed, onnozele, ge zijt stom-zat'.

'Ha! ik ben zat,' stotterde het ventje, 'ha! ik moet naar mijn bed, zo gauw niet, broer, ik wil bescheid weten, ik wil weten wat er is, ik ben verstorven van mijn ouders, ik heb naast $\mathrm{u}$ geërfd van Zalia, die ook haar wezepenningen had, en ik mag verzinken als ik er ooit een rode duit van heb gezien!' en Sarelken vloekte als een ketter.

'Ge zult de vermaledijding op ons huis en onze stallen trekken, waarschuwde hem Bouwen, oprecht bevreesd voor hemelwraak: 'Wie heeft $\mathrm{u}$ aangehitst, wie heeft $u$ dingen in het hoofd gezet, waaraan gij nimmer hebt gedacht?'

'Ik wil mijn deel, ik wil mijn woord te zeggen hebben evengoed als gij,' antwoordde Sarelken, halsstarrig, 'ik ben het slaven en het zwoegen moe; ik wil wat rusten in mijn oude dag, er moet hier een knecht komen, een hulp, of ik trek er vandoor; ik ga in 't klooster op mijn gemak mijn dagen slijten, en rekening zult ge moeten doen, met kaarten op tafel spelen, heel de ponk (1) te voorschijn brengen, hoort gij, broer?'

Of hij 't hoorde, Bouwen, of hij beefde, of hij bang was! Voorzeker tierde Sarelken aldus onder de invloed van de drank, maar daar stak iets onder, hij was te simpel om zelf tot de gedane ontdekkingen te komen... en een vermoeden doorflitste Bouwens brein... zou Feel hem misschien onder handen genomen, zijn ogen geopend hebben?

Bouwen brieste inwendig van toorn doch hield zich uiterlijk kalm.

'Wij zijn aan één wagen gespannen, uw belangen zijn de mijne,' aldus trachtte hij nog de dronkaard te sussen.

Maar deze hield vol: 'Ik heb hier zoveel recht als gij en ik heb nooit iets te zeggen gehad, ik moet dansen, zoals mijnheer mijn broer fluit...' en vloek op vloek volgde die schimpende uitbarsting.

Bouwen bezat zichzelf eindelijk ook niet meer, hij hief de vuist dreigend omhoog; doch eensklaps kwam een gevoel van deftigheid in hem op, wat wilde hij tegen een dronkaard redeneren? En met een vloek, even groot en grof als die van Sarelken, stond hij op, stiet het ventje terzijde en ging op het

(1) Spaarpot. 
donker hof, de klink met woestheid achter zich toetrekkend.

Hij hoorde het beekje vlieten en de grote beek murmelen, het rinkelen van de akers, die Trezeken, buitenkomend, neerzette, hoorde haar de staldeur zachtjes sluiten, en hij zag haar zwarte gestalte in de duisternis over de boomgaard naderen; hij zag daarboven de starren schitterend door de naakte fruitbomen twinkelen in de scherpe vrieskou van de winteravond.

'Alzo heeft ieder huisken zijn kruisken!' zuchtte hij diep-diep aangedaan, ontmoedigd en ontsteld.

De ganse nacht brak hij zich het hoofd om te ontdekken, wie zijn broer, zijn lijdzame, leidbare broeder aldus tot onverwacht verzet had opgeruid. 'Feel?' dacht hij, 'zou Feel hem opgestookt hebben?' Och neen, Sarelken kwam altijd recht van de vergadering van Franciscus-Xaverius naar huis. Bovendien Boudewijn had Feel met Trezeken zien terugkeren en aan het hofgat dralen.

'De drank,' besloot hij eindelijk, 'Sarelken zal ergens door de een of ander dronken zijn gemaakt onderweg,' - geld had het ventje zelf niet of niet genoeg. -

Maar wat een dronken mens uitspreekt, denkt en verheimelijkt een nuchtere. Er broeide onweer en Bouwen voelde, dat hij ernstig bedreigd was door het spook der toekomst: indien Sarelken eens werkelijk zijn wezepenningen eiste? Hij sidderde bij de onderstelling: de blikken doos met obligatiën uitgehaald, geopend, de effecten ontplooid, de cijfers opgenomen, aan 't licht gebracht, wat zo zorgvuldig in het duister bleef, de schat in twee gesplitst, weggedragen, deels of geheel op lijfrent geplaatst, alles in de bodemloze diepten van het klooster spoorloos verdwijnend! Het koud zweet brak hem uit, hij voelde dat hij het niet overleven zou, zo het gebeuren moest. De helft van 't zijne kwijt! - want ofschoon hij te eerlijk was om Sarelken iets te ontnemen, toch achtte hij - zolang hij 't niet verteerde of uitgaf - alles voor het zijne. Alleen het denkbeeld van het geld te tellen, te weten juist wat hij bezat - wat zij bezaten - joeg hem reeds de schrik op 't lijf. Hij wilde 't altijd doen en stelde 't altijd uit, bevroedend, dat de schat al groter werd en groter, onbewust zichzelf voor later - later een verrassing van gewicht voorbereidend.

\section{VII}

Geen woord over 't gebeurde in de morgenstond. Sarelken leed aan hoofdpijn en at niet. Bouwen deed hem geen verwijt.

Aldus verging de week, alles zijn slenter en gewone loop hernemend.

'Als de zondag maar goed voorbij kan gaan,' dacht Bouwen, wantrouwend geworden. Hij vreesde voor de avond en een nieuwe schermutseling reeds.

Zij kwam al vroeger dan hij had verwacht. Voor de vespers stond Feel daar reeds. Hij zette zich bij 't vuur, ontstak zijn pijp en sprak van onbedui- 
dende dingen. Trezeken was bezig in het schotelhuis. ${ }^{20}$ Sarelken zat als naar gewoonte te glimlachen en mengde zich niet in het onderhoud.

$\mathrm{Na}$ een korte poos van eensklaps ingetreden stilte der verlegenheid, begon Feel:

'Hawel, Bouwen, hebt ge u bepeinsd?'

'Waarop?' vroeg de boer, als uit de lucht vallend, met een uiterste poging om 't gevaar af te wenden, of voor zichzelf te loochenen.

'Op dat introuwen, ten onzent?'

'Bepeinsd en niet bepeinsd en toch bepeinsd,' sprak de oude man ontwijkend.

't Is maar,' hernam de aanzoeker, 'dat ik één of anders weten wil, moeder wordt hoe langer hoe ouder, mijn stiefvader is ook van de jongsten niet meer; er moet een hulp in huis komen, een vrouwmens, ik moet introuwen of mijn halfbroer Bernard moet het doen: als oudste heb ik de eerste keus... ge begrijpt, Bouwen...'

Ja, Bouwen begreep, hij begreep het maar al te goed, hem werd het mes op de keel gezet. Het gold te kiezen hier: zijn meesterschap bedreigd ofwel zijn haard verlaten zien.

'Feel, het ligt toch zeker in 't vuur niet?' stamelde hij om zo mogelijk nog wat te talmen.

'Bouwen, ge weet dat Bernard ook verkeert (1), hij vraagt niet beter dan mij van het erf weg te drommen; maar ik mag mijn beetjes niet laten pakken, hij zal er mij slechts wegkrijgen, als ik elders weet waarin...'

'Trezeken!' riep Bouwen radeloos.

Het meisje kwam tevoorschijn, stil, verlegen, de omgeslagen mouwen over haar blanke armen neertrekkend.

'Wat hebt ge daar gezeid, enige tijd geleden van bij mij te blijven, van nooit van hier weg te gaan?' vroeg haar oom en zijn lippen beefden, zijn kin beefde en de hand die achteloos met de blaaspijp speelde, beefde ook; een traan liep uit zijn oog in zijn stoppelbaard.

Trezeken wist geen andere raad dan luidkeels te beginnen snikken, terwijl de tranen daar botsten en zij in een tip van haar voorschoot beet.

'Kijk zie, daar zie, daar hebben wij het', zei Sarelken, met een verwijtend handgebaar naar zijn oudste broer.

'Ik zal ervan sterven! kreet deze.

Feel was opgestaan, hij had Trezeken aan zijn borst opgevangen. Zij had nu een arm om zijn hals, en het hoofd op zijn schouder gelegd. Feel kuste haar heel zacht, bijna onmerkbaar, zoete woorden van troost daartussen murmelend.

Het was duidelijk, dat de band, die de jongelieden samenbond, sterker was dan het snoer, dat Trezeken aan haar ooms hechtte.

'En ik zeg dit,' sprak Sarelken, 'dat als Trezeken weggaat, ik hier ook geen

(1) Verloofd is. 
oude top zal scheren, dat ik ook mijn matten oprol, dat zeg ik, dat zegt Sarel Velghe en daarmee punctum,' besloot het ventje zijn welsprekendheid.

'Ik zit tussen twee stoelen in de as, ik moet springen of banen!' (1) jammerde Bouwen.

En, heel overwonnen, bukkend onder de scepter van het noodlot, sprak hij, zijn nederlaag ontkennend, tot de beide gelieven:

'Heb ik u ooit verboden van hier in te trouwen?' en tot Trezeken: 'heb ik u ooit geboden van hier weg te gaan?'

Het meisje, onbekwaam om te antwoorden, schudde het hoofd, haar smekend, betraand aangezicht naar de beslisser van haar toekomst wendend.

'Heb ik u ooit een stro in uw weg gelegd aangaande uw verkeer met Feel?' hernam de oude man, zichzelf tot sentimentaliteit opwindend, 'neen, nietwaar?'

Voortdurend schudde Trezeken het hoofd, heel bewogen, op gelijke hoogte van aandoening met haar oom.

'Neen, neen,' bekende nu ook Feel.

'Welnu trouw dan, maar trouw hier in,' zei Bouwen, met het innig weegevoel der overwonnenen, aan 't zegepralend paar.

Er werd nog veel bepraat, nog veel bedongen en beslist die zondagachternoen. Trezeken bleef voor schade en bate als voorheen: Feel zou huur trekken als een knecht en:

'Wij zullen kweken wat er komt', zei Sarelken.

\section{VIII}

Met Pasen ging het jonge paar in de geboôn (2) en op derde meidag had het huwelijk plaats.

Als op vele boerenhoeven werden er bij de Velghen op die datum wafels gebakken.

'Zij moeten er komen eten,' had Bouwen inschikkelijk en vredelievend aan de ouders van Feel doen zeggen. De moeder deed antwoorden: 'Wij nemen 't in dank.'

Van de kerk terugkerend, had Trezeken onmiddellijk haar bruidsgewaad verwisseld tegen weekdracht en was ze aan 't beslagen van de deeg gegaan, terwijl Feel, die niet in gebreke wilde blijven, ook omgekleed, de koestal strooide.

Hel laaide de vlam van 't houtvuur als een welkomstvlag de ouders door het brede keukenvenster tegemoet, zodra ze traden over 't smalle boomgaardweegje, wit als een satijnen lint op groene zijde ontrold, heel oversprenkeld met de duizend madelievenstarretjes. De grote kruinen, alle in

(1) In grote verlegenheid, een bedenkelijk besluit moeten nemen in de ene zin of de andere.

(2) Van de kansel afgeroepen worden. 
lentebloei, met vinkeslag en badend in de zonneschijn. Een echte feestdag der natuur en die het ruwst en onontvankelijkst gemoed in feestelijke stemming brengt.

Trezeken bleef zitten aan de haard, de ijzers kerend om de beurt; alleenlijk keek zij om en knikte over haar schouder heen haar aangetrouwde ouders toe. Door de schielijke overgang van 't helder, scherpe licht daarbuiten in de laaggewelfde plaats, scheen het half duister hier en de houtvlam, hoog opschietend, legde een gulden tint van karmozijn op haar ronde wang en kin, en deed haar tanden glinsteren.

Feel tikte eens op haar rug, heel opgewonden, nieuw getroffen door haar schoonheidsbeeld:

'Nietwaar, vader, nietwaar, moeder, mijn wijveken mag gezien zijn?' zei hij blij.

'Zwijg, zot!' antwoordde Trezeken verlegen, haar aangezicht van de aanwezigen afwendend.

'Ze moet voor niemand onderdoen, zeg ik,' bevestigde haar schoonvader, 'en als ik het zeg, moogt ge 't geloven, zowaar ik Ruisschaert heet!' Hij had blijkbaar reeds enige borrels te veel.

'Toe, maak ze maar niet hovaardig,' zei Bouwen, 'trekt liever toe..21

En allen zaten rondom de dis, elk met een diep bord voor zich, waarin twee of drie wafels tegelijk gelegd werden, met warme melk overgoten en met grote brokken, zonder vork of lepel, druipend in de mond gestopt.

Trezeken bleef voortbakken. 'Wie tempert (1) en bakt, heeft immers geen lust om wafels te eten,' meende zij, een gekende waarheid aanhalend, die elk hoofdknikkend beaamde.

'Wij zullen er dan zoveel te meer voor ons hebben,' zei Ruisschaert, die geestig wilde zijn.

'Ja, ge moet mij immers “ineten”', (2) zei Feel.

'En toekomend jaar komen wij u “vasteten”, als 't God belieft', zei de moeder.

'Zie,' wierp Sarelken hiertussen, een paar wafels meer op zijn bord trekkend, 'zie, alzo eet ik voorgoed ons Trezeken vast', en allen lachten luidkeels om de minzame klucht.

'Allo, ge zit daar als een lijkbidder', zei Ruisschaert tot Bouwen, die wat ernstig bleef en bedenkelijk voor zich uitkeek. En toen: 'Daar, jongen, eens weelde is niet altijd armoe,' en hij stak Fik een groot stuk wafel toe, dat deze gulzig zonder knauwen binnenzwolg. Fik week niet meer van de zijde van zijn beschermer, ingelicht door het vlug hondenverstand, gretig, tuk op

(1) Beslaat.

(2) Eertijds, toen de dienstboden niet licht van plaats veranderden en bij 't jaar gehuurd werden, gingen de ouders hun dochter of zoon inleiden op derde meidag of Sint Huibrechtsdag (2 nov.). Zij werden op wafels of pannenkoeken vergast. Dat noemde men 'ineten'. Alle zes maanden op diezelfde dagen gingen zij ze 'vasteten'. 
nieuwe happen, de oren spitsend, met een straal van verlangen in het vorsend oog.

Dit mishaagde Bouwen, de zuinige man. Maar wat hem bepaald wrevelig deed worden, was toen Ruisschaert stoutweg in de kelder trok en met een mooie, bespaarde appel te voorschijn kwam, die hij, onder 't nieuwsgierig toeziende oog der aanwezigen, met gewichtige ernst begon te schillen, in kleine stukjes sneed en op een schaaltje legde, zeggend dat het suikerklontjes waren voor de koffie. Van zulke grappen hield de oude Velghe niet. En dan ook waarom noemde Feel hem vandaag nog immer kortweg Bouwen? Hij was nu toch zijn oom en had recht op eerbied.

\section{IX}

Maar hoe was het mogelijk, dat hij zich tegen dat huwelijksplan had verzet? Dit dacht hij thans bestendig alle dagen. Feel bleek een oprechte en grote hulp voor de stallen en het land te zijn. Bouwen en Sarelken voelden iets van degene, wie door een onbekende hand een last wordt van de schouders gelicht. Zij hadden 't ook zo kwaad gehad in de laatste tijden, en thans eerst ondervonden zij hoe oud en stram ze werden. Feel kende zich voor niets te goed: hij ging zelfs mee met het wiedvolk naar de vlasgaard en gaf het voorbeeld van de naarstigheid. Welk een verschil toch met de voorgaande jaren, toen 't oog van de eigenaars ginds noodwendig ontbrak.

Het enige wat Bouwen soms nog door het hoofd speelde, was de kwestie van het meesterschap: geen haarbreed mocht hij toegeven, op zijn rechten geen inbreuk laten maken; en bij meer dan een gelegenheid handhaafde hij dat meesterschap met zelfopgelegde gestrengheid: Feel had hem namelijk gevraagd om een gat in 't dak, en aldaar een duivepier ${ }^{22}$ te mogen maken, en een koppel duiven te houden voor zijn pleizier.

'Neen,' zei Bouwen, 'van een koppel komen er twee, van twee komen er drie, onkost, achternageloop, meedoen in prijskampen, vuiligheid op 't hof, neen, man.'

't Is goed,' antwoordde Feel kortaf; Bouwen zag, dat hij inwendig boos was. Een gevoel van verzachting, van toegevendheid ontstond, en deed hem pijnlijk aan, en hij was op het punt om op zijn besluit terug te komen, toen de altijd wakkere vermaner in zijn binnenste hem voorhield: 'Uw gezag behouden, meester blijven, indien ge de vinger geeft, pakt hij heel de hand; daar waar de tuin laag is trapt men er over,' en dergelijke spreuken van wijsheid en voorzichtigheid meer.

Dat was de eerste wolk aan hun hemel van solidariteit, en wie 't ontgelden moest was Trezeken: 'Geen dag verzet,' morde haar echtgenoot, toen ze alleen waren, 'slavenwerk, staan waar de bezem staat, altijd die oom in de ogen moeten zien, een kleine huur trekken, ik; geen gij. Had ik 't geweten, had ik het bij tijd overdacht!' voegde hij er kwetsend voor haar nog aan toe. 
Trezeken schreide, suste hem: 'Hij is toch het hoofd van 't huis, wij moeten onderdanig zijn. Indien hij ons eens aan de deur zette! Hij is toch zo braaf... hij was toch altijd zo braaf voor mij,' veranderde zij haar gezegde. 'Oom Bouwen is oud en oude mensen hebben grillen, wij moeten wat water in onze wijn doen en één zeel met hem trekken.'

'Ik zou wel willen weten,' hernam Feel strijdlustig, 'in wat ik aan mijn plichten tekort blijf. Eén zeel met hem trekken! maar het dunkt mij, dat ik alleen het zeel trek. Wat bedrijft hij hier? welke aarde brengt hij aan de dijk? Geen, volstrekt geen; integendeel hij dwarsboomt nog.'

'Gij moet toch denken dat hij pachter is,' weerlegde hem zijn vrouw.

'Ja, pachter, hij is pachter', bekende Feel nadenkend, traag sprekend, met een vonk in 't oog, 'maar indien hij geen pachter ware, zou ik hem een dans leren gaan!' Feel was opvliegend, wrokkig was hij niet. Zijn lichthartig karakter nam de bovenhand en hij ging weer zingend en fluitend aan het werk; maar halsstarrig was hij ook: hij gaf zich geenszins overwonnen en wachtte de gelegenheid af voor 't wagen van een nieuwe stormloop. Zijn duiven, o zijn duiven! niet zo spoedig verzaakte hij.

\section{X}

Intussen had de stem der goedheid ook weerklonken in 't gemoed van oom Bouwen, maar hij wapende zich tegen zijn eigen zwakheid: ' $U$ niet laten overrompelen,' hield hem de innerlijke waarschuwer voor.

En toch, toen met gelegenheid van de eerste kermis, op tweede pinksterdag, er een prijskamp voor het vee zou plaatshebben, en Feel hem nederig doch gretig-geestdriftig vroeg om mee te mogen dingen met hun vaars, gaf hij toe tegen wil en dank. Hij hield van dergelijke ondernemingen niet, zei hij, er was altijd gevaar bij: 'Jongen, ik ben van zulke markten thuisgekomen, maar indien uw groeze daarin steekt (1), doe het in Godsnaam, en Bouwen zuchtte met een bang voorgevoel.

Nochtans was hij fier, toen hij op de gestelde morgen de Witte, zoals zij genoemd werd, uit de stal zag halen: zo groot, zo welgebouwd, zo zuiver, glimmend blank en goedgevoed.

'Hé, welk een kop, zie eens die horens en die rechte ruglijn, zie die uier eens, voor zulk een jong beest!' Felix had Bouwen aangeboden zelf met de Witte te gaan, maar hij schudde het hoofd:

'Plaats maken voor de jongeren van jaren,' dacht hij met weemoed, en toch trots het mooi beest nastarend, dat leidzaam aan het zeel, zwaar stappend, 't erf verliet.

$\mathrm{Nu}$ was Feel eens recht in zijn schik. Hij mocht baas spelen met een illusie van meesterschap.

(1) Uw verlangen zeer groot is. 
Op de dorpsmarkt stond het vee in geïmproviseerde houten afsluitingen, de oudere melkkoeien hier, de vaarzen daar; de kalvers wat verder. Met grote ringen door de neus waren de stieren aan ijzeren krammen in de eeuwenoude lindestammen vastgemaakt. De varkens grolden en gilden bij de kerkhofmuur en woelden rozekleurig onder elkaar.

Aan de 'Steenput', de eerste herberg als men het dorp binnentrad, werden de hengsten gekeurd: prachtig, kloek, zacht-gehoorzaam aan hun geleider, op een draafje $\mathrm{e}^{23}$ lopend, stilstaande bij het eerste bevel. En de leden van de landbouwcommissie gingen rond, het notaboekje en het potlood in de hand, dicht op de hielen gevolgd door de nieuwsgierige menigte, welke de twee veldwachters moeite hadden op eerbiedige afstand te houden.

Het weer was van 's morgens vroeg betrokken en onweersachtig-zwoel geweest. Toen Feel van 't hof ging, voelde hij een regendruppel, nog een en nog een, en nauwelijks stond de Witte in het voor haar bestemde vak, of 't werd een stille, aanhoudende zijpeling, al dichter en dichter, en eindelijk een in rechte stralen neerschietende lenteregen.

Het volk trok hier en daar de herbergen binnen. De juryleden, welke het eerst dapper uitgehouden hadden, gingen zelf schuilen, hoopvol of wanhopend in de lucht kijkend, en het hoornvee bleef aan de bui blootgesteld.

De Witte, welke om zo te zeggen nog bijna niet uit de stal was geweest, kreeg rillingen door haar roomkleurige huid. Weldra was de markt één modderpoel; de koeien loeiden en de zwijnen grolden luider; de stieren stampten ongeduldig, maakten plompe zijsprongen of beukten naar de lindestam, waaraan hun keten vast was.

Feel bleef bij zijn beest staan; zelf doornat, zag hij, medelijdend en misnoegd voor zulk een tegenslag, die reeksen arme koeien aan. Enkele boeren hadden een deken of een baalzak op de rug van hun mededingers gelegd. Feel had niets dergelijks bij de hand, en het water stroomde glimmend van de ruglijn langs de poten van de Witte neer.

Feel kreeg dan toch een beloning, een voldoening, die, ofschoon verwacht, altijd onzeker blijft: hem werd de eerste prijs toegewezen: een zilveren medaille en een som van honderdvijftig franken.

Een beestenkoopman bood hem daarenboven op staande voet vijfhonderd franken, wilde hij de Witte laten. Het was een echte landbouwersoverwinning. 'Laten?' De verzoeking was groot, het voorstel hoog. Eilaas! Hij kon niet, mocht niet, 't beest behoorde hem niet toe. Hij krabde achter zijn oor, hij wilde zijn voogdijschap niet bekennen. Eindelijk zette hij er een vloek op: 'Niet te koop', zei hij bars, met Bouwens vaarze door de regen heentrekkend.

Bouwen stond op de uitkijk.

'Triomf!' riep Feel van verre zijn medaille aan een blauw lint omhoogzwaaiend.

Het was nog wat anders toen de grijsaard de toren opeengestapelde vijffrankstukken zag: zijn oog tintelde van begeerlijkheid, en in een behoefte van geestdriftdoving bij zichzelf en bij de brenger van het zegepraalsbericht zei hij: 
'Als de Witte er maar niets van krijgt, in zulk een hondenweer, hebt ge gezien hoe haar rug doomde, toen ge ze in de stal leidde?'

'Ja, ja, ja!' antwoordde Feel luchtig, 'en in Holland dan? en in sommige streken van ons land waar de koeien van in 't voorjaar tot Allerheiligen dag en nacht in de weide lopen? Zijn ze er te slechter om?'

Bouwen haalde een grauwe beurs uit de zak, betastte ze van onderen en nam uit een der hoeken een stuk van twee franken, dat hij, met een vasthoudende kramp van de vingers aan Feel gaf. Klinkend rolden de zilverstukken in 't linnen op malkaar en spoedig was de beurs spoorloos in de zak van Bouwen verdwenen.

'Danke', zei Feel. Hij was zo nat, dat een ronde plas de plaats aftekende, waar hij stond.

Hij ging zich in zijn slaapkamer omkleden en voordat Trezeken droog dingen uitzocht, toonde hij haar de open grote hand met het kleine stukje erin: 'Kijk, hoe 't hier sneeuwt,' (1) zei hij. 'Die hond, die gierigaard, dat beest,' zo viel hij uit, vermaledijdend en verdoofd tempeestend. 'Dat zal mij leren met zijn koeien naar de keuring gaan! Ik wenste dat hij al zijn ribben brak, ik wenste dat hij...'

'Zwijg, zwijg, hij zal het horen!' suste het beangste vrouwtje en zij had een onvoorzichtig woord, zij zelf: 'Zwijg, verdraag het, Feel, wat onkel Bouwen bezit, moet toch vroeg of laat aan ons komen.'

Het was merkwaardig, hoe die flikkering van hoop zijn brein verlichtte en zijn toorn bedaarde. 't Moest alles aan hen komen! en tussen dat komen en het zelfbezit bleef er maar een stap te doen - het was het hunne in verbeelding reeds.

'Als onkel zijn hoofd legt, zal ik die en die verandering invoeren,' zei Feel bij elke gelegenheid, in de herberg aan zijn kameraden.

En zij antwoordden, meest om hem uit ijverzucht te tergen en zijn snoeverij te verootmoedigen:

'Op een oude tante mag men rekenen, maar een oom is een droom.'

'Een droom!' hij zou wel eens willen zien, of Bouwen 't wagen mocht een cent te verstellen! (2)

Van Sarelken werd niet gesproken, net als had hij hier geen recht en niets te vergen.

Was de voldoening bij de oude jonkman groot geweest, hoe bitter moest hij die weldra ontgelden. Geen drie dagen later of de Witte was ongesteld: eerst weigerde zij haar ate, (3) dan gaf ze schier geen melk meer. Zij lag onbeweeglijk, met rode, onheilspellende koortsogen naar de in de stal komenden omkijkend.

De veearts werd gehaald. Hij schudde 't hoofd, hij deed om medicijnen

(1) Hoeveel drinkgeld ik krijg.

(2) Bij testament aan niet-erfgenamen nalaten.

(3) Eten. 
zenden naar zijn huis. 's Anderdaags keerde hij weer: de koe had longontsteking, daarenboven was de melk in het bloed geslagen. Elk ogenblik kon ze horendul (1) worden.

Geen tijd te verliezen, men moest ze afmaken, wilde men dat hij - expert voor het omliggende - op zijn eer en volgens zijn geweten het vlees nog als eetbaar goedkeuren kon.

Zulk een schone vaars! vijfhonderd franken er voor geboden! 'Vijfhonderd!' jammerde Bouwen als om het cijfer - als een mes - scherper in zijn leedwezen te doen snijden. 'Vijfhonderd franken!' herhaalde hij, 'en dan de prijs van honderdvijftig maakt zeshonderdvijftig! En nu hoeveel zal er nu van 't vlees - onder de markt (2) verkocht - wel komen?'

Feel ook had spijt, geweldig spijt - en hun gemeenschappelijke smart werd een oorzaak tot wederzijds verwijt.

'Ziet ge wel, dat komt ervan als men niet meester is', zei Feel. ' $I k$ zou geen ogenblik geaarzeld hebben om ze te laten.'

'Lag dat zodanig in 't vuur? Wonen wij een uur van het dorp af? Kondt ge geen kort uitstel vragen en mij komen raadplegen?' zei Velghe.

'Het was alzo nog schoon weer om over en weer te lopen,' antwoordde Feel en strijdlustig, op twist gesteld: 'met de koe door regen en slijk of zonder de koe? Ik had ze zeker ginder onbewaakt op de markt moeten laten lopen, om nog daarbij aan de boet ${ }^{24}$ te zijn? Wat had het mij kunnen schelen ook wat ervan kwam,' en hij haalde de schouders op.

Hij had zijn aangetrouwde oom en gebieder echter, onwillens, een nieuw wapen ter hand gedaan:

'Ja, door de regen en het slijk!' sprak deze bitter. 'Wat moest ge ginder met dat beest gaan lopen om plagen te gaan zoeken; besmetting en wat weet $\mathrm{ik}$ al! Ik heb zolang geboerd en al zeg ik 't zelf, wel geboerd, maar heb nog nooit in zulke zotheden meegedaan.'

'Zotheden! hoort gij, Treze, zotheden? Bouwen noemt het zotheden, als ik hem honderdvijftig franken thuisbreng voor welke hij nog geen vinger verroeren moet!' zei Feel gekwetst en tergend.

'Zwijg,' bad Trezeken bang en ontdaan.

'Ja, zwijg,' beval hem Bouwen op een toon van toorn, die geen weerspraak meer gedogen zou. Zo energiek en vastberaden had hem Felix nooit gezien. Hij boog het hoofd voor de sterke wil van dat oppergezag; maar hij kraakte zijn tanden op malkaar, inwendig vloekend, Bouwen en zijn meesterschap vermaledijdend.

De veldwachter had het uitgebeld, van tijd tot tijd luidkeels langs de dorpsstraat roepend: 'dat Boudewijn Velghe een vette vaars geslacht had en dat het vlees verkrijgbaar was aan één frank de kilo.' Luid deed hij 't laatste woord als een klacht ten hemel op weergalmen.

(1) Razend.

(2) Beneden marktprijs. 
Geen mens die zich aangaande dit 'slachten' verschalken liet; maar 't afgemaakte beest was door de wetenschap als bruikbaar goedgekeurd en de prijs stond laag. Daarom ging elk of bijna elk naar 't hoeveken van Velghe.

Onder de bloeiende appelboom, teer en fris roze, stond op 't groene gras, de lange tafel met de stukken steenrood vlees. Het was een warme lentedag met zonneschijn en hemelsblauw, een dag tot opwekking van blijde stemming en van vreugd, heel niet in harmonie met 't hier aanwezig boerenverdriet.

Bouwen had slechts achttien franken voor de huid gekregen: 'Alzo een schoon vel, 't is God te klagen!' en hij haalde de tijd aan, dat hij voor minder schone vijfentwintig franken gehad had.

Wat hem ook ergerde was te zien, hoe Sarelken zich te vermaken scheen en, met de glimlach op 't gelaat, ofschoon geheel onwerkzaam, een levendig aandeel aan 't gebeurde nam. 't Misviel aan Bouwen, dat Feel met de gaanden en komenden schertste en dat Trezeken, het stille Trezeken meegesleept door de vrolijkheid, welke meest altijd een druk mensenverkeer begeleidt, tenminste als er geen oorzaak tot grote kwelling bestaat, dat Trezeken meelachte en bedrijvig woog en bestelde, als had zij nooit anders in haar leven gedaan, en dat zij haar bebloede vingeren aan haar met bloed beplekt voorschoot onverschillig afveegde, het bloed van de Witte - van hun geliefde koe!

Nog wat meer en hij, Bouwen, zou boos zijn geweest, omdat de verkoop zo ras en flink geschiedde en alles zo spoedig, zonder vrees of afwachting wegtrok.

$\mathrm{Al}$ zijn gras was platgetrappeld, een nieuwe bron van ongeduld en van misnoegdheid.

\section{XI}

Op het einde van de tweede herfst werd er een kind geboren op het hoeveken.

'Dat komt van trouwen,' zei Sarelken in de blijde, feestelijke stemming, die een geboorte teweegbrengt. Bouwen deed alsof hij het niet wist of de gebeurtenis te gering achtte om ervan te gewagen. Hij was geruime tijd tevoren verzocht geweest om peter te zijn, doch hij hield zich tevreden met de hem gegeven eer. Hij had namelijk het vast voornemen gemaakt die tegenwoordigheid te dulden, meer niet; nooit wilde hij met dat 'jong goed', zoals hij 't bij zichzelf noemde, iets gemeens hebben, daarom zei hij:

'Neen, het lust mij niet meer, ik ben te oud, Sarel kan in mijn plaats gaan.'

Maar het ventje was weer moedwillig:

'Al of niet,' zei hij, 'indien ik het doe, is 't voor mijn rekening, ik ken mij te treffelijk om peetje-lap (1) te zijn.

En men had vrede met het voorstel.

(1) Peter volgens volmacht zijn, in naam van een ander. 
Uit gewoonte van onderdanigheid echter, ofschoon hij alleen, als peter van een knaap, tot het kiezen van een naam berechtigd was, vroeg Sarelken, met zijn beste klederen aan tot bij het bed van Trezeken gegaan:

'Hoe moet het heten?'

En Trezeken antwoordde zeemzoet:

't Is mij om 't even... maar... het moet Basiel heten.'

'Nu weten wij tenminste wat ons te doen staat,' sprak Sarelken gewichtig.

Het kind werd Basiel gedoopt, maar voordat men weer met hem thuis was, ontaardde de naam in Berzeel en aldus bleef het heten.

'Bouwen, kijk eens naar onze kleine,' had de baker, belust op een fooi, tot de oude jonkman, terugkomend gezeid, en zij sloeg de panden van haar zwarte mantel achterover om hem het busseltje voor te houden.

Doch, ongewillig, wendde hij het hoofd af:

'Laat maar zo, hij zal zonder mij wel groot groeien,' was zijn weigering.

Het kind moest gewassen worden en daar het reeds koud en mistig was, gebeurde zulks bij de haard, “"uitgevuurd” (1) moet het wezen,' zei de baker, en een halve ochtend kon ze daar voor de vlam zitten wiegen en waggelen op haar stoel. Wat vond oom Bouwen dat vervelend!

Erger nog was 't als de kleine erbarmelijk begon te huilen en er tevergeefs werd op zijn rug geklopt om hem tot bedaren te brengen.

Telkens wist de vrouw te verklaren, dat het buikpijn was en trippelend en stampend met de voeten, liep zij in de keuken rond. Soms ook neuriede zij.

'Maar zwijg dan toch!' beval haar Bouwen, wie het gezang nog meer dan het geschreeuw hinderde.

En daar zij, sterk door het recht van haar bediening, zich volstrekt niet stoorde aan zijn misnoegen, stond hij zelf op, duwde schrappend zijn leunstoel achteruit, verruimde zijn keel als een dreigement en ging buiten, de deur met geweld in de klink trekkend.

'Alzo een vies man!' (2) zei de baker, Trezeken verontrustend.

'Het zal beteren als ik op ben,' dacht deze, maar het smartte haar dat Bouwen nog niet eenmaal tot in haar kamer was geweest.

'Heeft hij nog naar Berzeel niet gekeken?' vroeg ze meer dan eens daags.

'Neen, maar Sarelken is er zot van, het zit ermee op zijn knieën net als een vrouw.'

Helaas, Sarelkens liefde was een te gering geschatte aanwinst om de verscholen vijandelijkheid van onkel Bouwen te vergoeden.

Trezeken had haar kerkgang gedaan, zij verrichtte weer haar bezigheden in huis en in de stal; fris als een roos, vlijtig liep ze rond, en Bouwen gevoelde met welbehagen opnieuw haar kleine zorgen en oplettendheden: zijn klompen gerokkeld (3), een sjerp aangebracht wanneer hij buiten ging.

(1) Met de blote beentjes voor 't vuur gehouden.

(2) Rare kerel.

(3) Met gloeiende, dadelijk weer weggeworpen as van binnen verwarmd. 
Alle avonden, voordat Trezeken zich naar haar bed begaf, was ze van jongs af aan gewend bij hem te komen, half te knielen, half te buigen en te zeggen:

'Onkel, als 't u blieft, geef mij een kruisken.'

Toen deed hij de beweging, prevelend: 'God beware u!'

Ditmaal had ze haar kind in haar armen, 'Onkel...' zei ze, de gebruikelijke formule herhalend en hij zegende haar op het voorhoofd.

Maar zij ging niet heen: 'Onkel,' herhaalde zij dralend en blo: 'geef Berzeel ook een kruisken.'

En hij drukte zijn ruwe vingeren op het hoofdje van haar zoon.

'Danke', zei Trezeken, met haar schone ogen de oude man aanziende.

Alle avonden gebeurde nu hetzelfde, maar het bleef daarbij.

Basiel was een lastig kind, dat veel schreide en ofschoon Bouwen geen eigenlijke klachten daarover uitte, kon hij toch binnensmonds brommen, als het geschreeuw wat lang aanhield.

Dat geschreeuw maakte de bestendige schrik van Trezeken uit, vooral 's nachts:

'Och, Feel, hij zal het horen', lispte zij bang. 'Dat hij zijn oren stoppe,' zei Feel.

'Er worden geen kleine jongens opgekweekt zonder dat ze hun keel openzetten, wij zijn ook al zo geweest,' verklaarde Sarelken. 'Indien het maar zomer ware,' voegde hij erbij, 'ik zou eens met hem rondom de bogerd gaan en hij zou wel zwijgen.'

Intussen kon dat niet, er lag sneeuw, het vroor; boerendeuren sluiten niet dicht, van onderen door de reten tochtte het.

'De wieg staat daar te koud', had Trezeken meer dan eens tot Feel gezegd, en begerig had ze naar de warme hoek gekeken, waar oom Bouwen zat.

'Wie meester is, doet wat hij wil en zit waar hij het verkiest,' bromde Feel.

'Ja, wij moeten water in onze wijn doen', zuchtte zijn vrouw.

'Dat acht ik goed,' zei Feel, twistziek, 'daar heb ik niets tegen in te brengen, maar ik klaag als het allemaal water is, water zonder wijn', grinnikte hij. Het linnen van het kind werd bij de kachel gedroogd, het hing op de rug van stoelen, zodat Sarelken bij het vuur niet meer kon, en Bouwen zijn zetel achteruitschuiven moest:

'Gaat die boel hier nog niet haast weg?' vroeg hij soms ontevreden.

'Waar kan ik nu met dat alles naar toe?' jammerde Trezeken achterrug, nadat ze't weggenomen had.

'Hang het er stoutweg weer', raadde Feel, maar ze durfde niet.

Het kwetste haar in haar moederliefde, dat oom Bouwen Fik streelde, hem op de schoot nam, zoete woorden toevoegde en geen blik had voor haar zoon.

'Onze jongen is er te veel', zei ze bitter.

'Bij Sarelken toch niet,' weerlegde haar Feel.

'Och, Sarelken!' zei ze met geringschatting en gevleide tevredenheid. 


\section{XII}

'Ieder kind brengt zijn liefde mee,' zegt het spreekwoord. Hier werd het nogmaals bewaarheid: Bouwen, die zich zo ontoegankelijk bewees voor de kleine, sloeg niettemin zijn ontwikkeling gade, onwillens gevangen door zijn lachjes, door de beroering van zijn eigen vingeren op de zachte, warme huid, en meer dan eens was het gebeurd, dat hij, alleen met het wicht in huis zijnde, schommelen ging, wanneer het huilde, het toedekte, als 't zich ongedurig blootgesparteld had; maar zodra hij de melkaker van Trezeken aan de staldeur hoorde kletsen, zat hij weer roerloos rokend in zijn hoek, als ging dat schreien hem niet aan.

Op een morgen, nadat het kind de ganse nacht gesteend ${ }^{25}$ had, verschrikte zijn moeder, toen ze 't uit de wieg nam en naar het licht hield:

'Kijk eens, Feel, al rode vlekjes op zijn aangezicht!' Zijn oogjes liepen over van de tranen, al schreide het niet meer; het hoestte.

't Zijn zeker de mazelen,' meende zijn vader. Trezeken was nooit in de kinderen geweest, hij wel, hij had dat verschijnsel bij kleinere broertjes en zusjes waargenomen.

'Zo jong!' weerlegde hem Trezeken, doodsbang.

De dokter werd gehaald.

Het wiegje stond op zijn gewone plaats in de keuken.

Beknibbelend zag hij rond:

' $t$ Is daar te tochtig', zei hij, 'indien ge wilt, dat uw kind geneest en geen zere ogen uit de ziekte behoudt, moet ge zijn wiegje elders plaatsen.'

Elders! er was maar één warme hoek in heel de keuken: Bouwens zetel werd in de andere kant getrokken, de wieg in de plek gesteld.

'Onze jongen gaat sterven!' kreet Trezeken, in het toppunt van angst, met verwilderde ogen, rood, als uitzinnig.

En toen haar oom binnenkwam, bemerkte hij met één oogopslag de onverwachte ruiling, het 'verdrommen ${ }^{26}$ van zijn troon; maar hij bemerkte en vatte nog iets meer: dat hij met een sterkere macht te doen had dan de zijne: met de macht der moedermin! Hij besefte, de oude meester, dat Trezeken leeuwenmoed bezat, en desnoods leeuwenklauwen gebruiken zou om haar kroost te verdedigen:

'Ons kind gaat sterven!' huilde zij ook tegen hem, van wanhoop in haar voorschoot bijtend.

Het klonk als een verwijt in zijn oren.

'Berzeel heeft kou gevat, hij heeft de mazelen!' en oom Bouwen, in alvergetelheid van zijn terughoudende stugheidsrol, was ook ontsteld door het bericht en zei: 'Toe, toe, het zal zo erg niet wezen', en hij boog zich over de wieg.

'Onze lieve Heer moet zijn getal hebben, alle kinders worden niet geboren om te blijven leven,' had Sarelken steeds gezeid, wanneer hij van een overlijden in de buurt hoorde; maar nu was dit geen troost voor hem: 'Een mens zou er zich zelf te sterven bij zetten,' zei hij hoofdschuddend. 
Bouwen zat op de hem beschoren plaats, met een gevoel van vreemdheid, van noodzakelijkheid en toch van overrompelingsbesef. Hij kreeg rillingen en had een sarge ${ }^{27}$ over zijn rug gelegd.

Fik zag verwonderd toe: met de oren gespitst en de twee voorpoten op een stoel, blafte hij de wieg aan, als de openbare aanklager van verkeerde dingen, die hier geschied waren, met de muil naar omhoog blafte hij dat langgerekte noodsein van verontruste honden uit.

'Wilt ge wel zwijgen, stouterik!' riep Trezeken, hem dreigend met haar uitgetrokken klomp; en Fik ook zwichtte voor de overweldigende oppermacht en sloop druiporend onder de leunstoel van zijn meester.

Het kind genas, maar de wieg behield de plaats der verovering.

Basiel kon nog niet alleen lopen, toen er een tweeling geboren werd. $\mathrm{Nu}$ hielden de drukte en 't schreien niet meer op in huis. Er moest een koewachter gehuurd worden, want Sarelken had van lieverlede het ambt van kindermeid op zich. Hij ook was het die nu de aardappelen en de pap kookte, Trezeken had geen tijd.

Bouwen werd verwaarloosd. Zijn gemoed was gedrukt en met bitterheid overdacht hij de benarde toestand: 'Wij waren gelukkig met ons drieën. Zuinig leefden wij. Nauwelijks wat meer dan twee jaren getrouwd en wat is het nu: Ik en Sarel, Trezeken en Feel, drie kinderen en een koeier, met acht mensen alle dagen! acht mensen in de kost!' jammerde hij.

Wanneer er spoedig een vierde kind kwam, was het Boudewijn om het even, hij aanschouwde de nederlaag als hopeloos. Zijn gezondheid verzwakte, hij ging niet meer rond met de schaal in de kerk, en had sinds lang geen voet meer in de herberg gesteld.

Felix trok des zondagsnamiddags eens tot aan het dorp of zijn ouders huis. Sarelken was een trouwe bezoeker gebleven van de vergaderingen van zijn Xaverius-genootschap, de enige hem beschoren treurige verstrooiing van een ganse week; en Bouwen zat heel de tijd in de hoek, de vreemde hoek, tot de schemering neergrijsde in de eigenaardige droefheid van een winteravond op een boerenhoeve: de hennen die vroeg naar de roest (1) trekken; mussen een ontijdige schuilplaats zoekend op een spijker onder 't dak; de deken van de nacht allengs over de schuur en de fruitboom en in onverstoorbre stilte neerzijgend; reuk van beestenkost daarbinnen in een grote ketel, schijfopheffend brobbelend over de houtvlam - 't enig licht - en met het heengaan van de dagklaarte verhoogd kindergeschrei. Trezeken sussend of bedreigend met een straf - straffend nooit.

Meer dan eens was hij in geding met zich zelf eenmaal - ondanks de kilheid - rondom de stukken of al ware het maar tot in de stallen te gaan, doch waartoe goed? Daar ook zag hij zijn 'onwil': de koeien stonden vuil, aangeladen, slecht gestrooid, de kalvers 'gedijden' niet als eertijds; biggetjes werden wegens te grote last niet meer gekweekt.

(1) Slaapplaats voor't pluimgedierte. 
In de zomer was het niet beter: de dagen waren te vervelend lang. Buiten op de bank voor de deur zat de grijsaard nu, en het was hem een oprecht verdriet de dingen om zich heen met ogen van spijt op te nemen: Kindergoed, gescheurd reeds en versleten, dat tussen de bomen te drogen hing of op de bleek lag; stro geijkerd (1) hier en daar; stukken van grauwpapieren zakken, stokken, stenen, waarmee de kleinen hadden gespeeld; brokken van een kroon gevlochten madeliefjes, half verslenst, zorgeloos weggeworpen. - Niet dat hij het behoud van die bloemetjes op prijs stelde, een landbouwer voelt niets dan geringschatting voor hetgeen hij onkruid noemt. Maar hij vond het slordig, het hinderde hem in zijn reinheids- en ordebehoeften.

Tevergeefs berispte en morde hij. De kleuters vonden bij moeder en bij vader steun, die steun van werkeloos toezien en verholen dulden.

'Ik zal hier weggaan,' dacht Bouwen soms; maar hij wist wel dat hij dat niet kon: hij was hier vastgegroeid als de bomen op het erf, te vele wortelen en vezels hechtten hem aan de grond om nu nog - zonder vermoorden uitgerukt te zijn. Hij was hier gekrompen en vergrijsd als het dekstro op de schuur; hij wist precies hoe diep hij nog buigen moest om in of uit de achterdeur te gaan; hoe hard hij trekken moest om water uit de pomp te krijgen - hij stond hier vast als die pomp.

De duiven - want nu waren er - zaten op de grond of op de vers geschilderde vensterkozijnen, dat ergerde hem ook; het maakte hem kregelig hun gekir te horen en ze te zien vliegen in hun kringvormige bochten boven de bogerd en het huis. Zij deden daarenboven schade aan de gezaaide veldvruchten; maar aan de duiven dorst hij niet meer roeren, Feel had hem meer dan eens desaangaande het hoofd geboden: hij had hem bedreigd Fik dood te slaan als weerwraak, moest hij zijn duiven missen.

'Wat hoeven wij die oude knorpot zozeer te ontzien, sprak hij tot Trezeken,' wij hebben hier meer recht dan hij: Sarelken spant met ons, gij zijt een zusters kleindochter; van de drie parten bezitten wij er twee.'

Aldus redeneerde hij in zijn wrok. Maar tot eisen durfde hij niet zijn toevlucht nemen, Bouwen boezemde hem nog te veel ontzag in.

Trezeken ook zette zich dat recht op meesterschap in het hoofd; oom Bouwen was een troon- en fortuinrover.

\section{XIII}

Plotseling stierf Sarelken.

Dat was een grote slag voor allen. Het ventje had gedurende heel zijn leven de heilige Barbara, patrones tegen de subiete ${ }^{28}$ dood, bijzonder vereerd en helaas! het was hem toch niet zalig geweest 'een beddeken van penitentie

(1) Slingerend. Uit de bundel gevallen. 
te hebben' (1). Bouwen had nooit veel omgang met die jongere, onmondig gebleven broeder gehad; maar het was toch een band die van hem werd losgescheurd. Trezeken vooral voelde de beroving, en de oudsten van de kleinen, die de tijd niet hadden gehad zich allengs van hem te ontwennen, schreiden hartbedroevend: 'Bij Sarelken zijn! Bij Sarelken gaan!' net als zij deden des zondags, wanneer het oompje tijdelijk uit was.

'Sarelken was daar gauw weg,' zeiden buren en bekenden aan Felix, en het kwam gans natuurlijk, dat erbij gevraagd werd:

'En hoe stelt Bouwen het nog?'

'O,' antwoordde hij luchtig met een verachtend schouderophalen, 'die zal het al overleven, zijn ziel heeft een schielde aan (2),' of hij zei half grappig half ontevreden: 'Ik geloof dat zijn ziel beroest zit in zijn lichaam.'

Het afsterven van Sarelken trof Bouwen ook in zijn hebzucht: hij moest erfenisrechten betalen en, ofschoon hij veel verheimelijkte, was het toch te goed gekend, dat er effecten bestonden, en betalen moest hij voor het aangegeven deel. Hoeveel zei hij niet aan zijn huisgenoten. Ontoegankelijker dan ooit sloot hij zich op in zijn kamer als zijn koffer geopend werd.

'Hij blindpot (3) dat allemaal voor ons,' klaagde Felix in zijn ouders huis. 'Hij moet rekening doen en u geven, wat u toekomt', zette hem Ruisschaert, zijn stiefvader, aan. 'Dwing hem met kaarten op tafel te spelen.'

'Wie geen zotten in huis heeft, weet er altijd weg mee', zei Feel, terugschrikkend voor de moeielijkheden van de strijd.

Intussen was het tijdstip weer daar, waarop Bouwen naar de stad moest voor de ontvangst van zijn rentebriefjes. Zijn klederen waren deerlijk gehavend: zijn halssjerp in flarden, gaten aan de vingerlingen van zijn wanten, zelfs geen gewassen halsboordje om aan te doen, en als een beschuldiging hield hij er aan Trezeken een paar gescheurde en uitgerafelde voor.

Zij had geen tijd, antwoordde ze en wendde hem de rug toe. Nu ging hij zoeken in 't vuil linnen, wat het best nog dienst kon doen.

Terwijl hij weg was, wonden de twee echtelingen elkander tot weerstand op.

Het zwijn was juist gedood die dag, en Felix had met de slagers een borrel te veel gepakt. Hij blaakte hoogrood, hij was stout door de drank, en zijn misnoegen zocht een uitingsklep. Zodra Bouwen thuis kwam, trad hij driest op hem toe:

'Bouwen,' begon hij strijdvaardig, 'wanneer schikt ge eens van zaken te

(1) Een lange ziekte om zich doelmatig tot de dood te bereiden.

(2) Om kippen te beletten door een haag of een afsluiting te kruipen, bindt men een stok of stuk hout, dat uitsteekt langs weerskanten, onder hun vlerken vast. Dat noemt men een schielde. Figuurlijk wordt die spreuk toegepast op iemand, die te lang leeft voor zijn ziekte-oppassers of zijn erfgenamen.

(3) Verbergt. 
spreken en ons te geven wat ons toekomt? Sarelken is nu al zolang dood, en van haar grootmoeder, die uw zuster was, is Treze ook verstorven.'

Daar was de bom losgebroken!

'Van zaken spreken,' herhaalde de grijsaard, heel verbluft, ten uiterste bevreemd, 'u geven wat u toekomt? Zijt ge gek, man? Weet ge dan niet - en tegen zijn gewoonte ontsnapte hem een vloek - dat een bastaard niet delen kan?'

Trezeken stond erbij met een kind op de arm. Het viel er bijna af, zozeer verschrikte zij, en het was Feel als had hij een slag in 't volle gelaat gekregen. Hij deinsde achteruit, hij grijnslachte eens gemaakt, uit ontzette verlegenheid: zij waren zelfs geen erfgenamen!

Hij wilde er zekerheid van hebben en nam de eerste gelegenheid waar om er een bevoegd persoon over te spreken: het was aldus.

'En nu mag hij ons op de straat zetten, na al ons zwoegen en ons werken zonder loon,' zei hij thuiskomend aan Trezeken, 'indien hij sterft, is 't al voor verre bloedverwanten!'

'Een testament?'

Hoe hem daartoe te bewegen in de huidige verhoudingen tot malkaar? Lang, reeds heel lang was de vleitoon afgeschaft, de vijandelijkheid schier open bekend! en zij zonnen erop na met een onrust, die hun leven vergalde.

\section{XIV}

Gedurende de winter deed oom Bouwen een verkoudheid op, hij hoestte en week niet van het haardvuur. Fik zat nevens hem, heel dicht tegen zijn been aan en Berzeel stond tussen zijn knieën; hij had die jongen lief gekregen, het kwam hem - ondanks alle grieven - niet in de zin zijn huisgenoten te onterven; maar hij vond dat er geen haast bij was maatregelen tegen zijn einde te nemen. De huurceel moest vernieuwd worden, deswegen verscheen de toeziener:

'Als ge denkt,' zei Bouwen, na een aandachtige koprekening, 'dat onze familie hier al negentig jaren woont!' Hij merkte niet dat de man met enige verlegenheid herhaalde als een gedachteloos echo: 'Negentig jaren!'

'Kijk, Bouwen, hier zijn enige sigaren voor u,' hernam hij en gaf er hem. De grijsaard was geen mensenkenner, hij sloeg er geen acht op, dat Feel de toeziener tot aan het hek uitgeleide deed, en de beiden ginder ernstig schenen te beraadslagen.

De pachtbrief moest notarieel zijn als vroeger, maar op de gestelde datum voelde Bouwen zich niet goed genoeg om te gaan. Felix verving hem. 'Laat zien?' vroeg hij, de bevende hand naar de meegebrachte omslag bij dezes terugkomst uitstekend.

Onbeschroomd gaf Feel hem die af.

Bouwen zette zijn bril op: 'Wat is dit nu?' de pachtbrief sprak op hem niet meer. 
'Op mij,' zei Feel zijn borst aanwijzend. 'Ze zullen ons hier nu niet uitzetten na uw dood,' voleindigde hij gruwzaam.

Geen huurder meer! bij anderen inwonen!

Er viel een vloek, gewisseld werden grove woorden, maar het bleef daarbij. Het hart vol wrok, het bloed in opstand, boog de oude man het hoofd, zijn zwakheid voelend tegen overmacht...

's Anderdaags bracht de postbode een brief.

Dat was een zeldzaamheid op het hoeveken, dat verwekte ontsteltenis en gebeef bij de handen, die hem openden. Bouwen lei hem voorlopig neer, hij was gewend de besteller als een gast te aanvaarden. $\mathrm{Nu}$ hield een bangheid, een zedelijke drukking hem tegen om naar de glazenkast te gaan, waar hij nochtans de fles half vol zag staan en hem een borrel in te schenken, ofschoon noch Trezeken noch Felix aanwezig waren.

De briefdrager draalde aan de deurlijst, tuk op zijn loon.

'Wacht even,' zei Bouwen, heel verlegenheid, en op het schoorsteenblad nam hij een paar sigaren van het daargelegd hoopje.

Dat was nog beter dan een glas jenever.

'Salut,' zei de bode, militarisch naar zijn voorhoofd wijzend, en weg was hij met de haastige stap van de bedrijvige.

De brief was van de wisselaar: de stad Brussel zette haar schuld om aan verminderde interest, en de titels moesten ingediend worden vóór een bepaalde datum.

Bouwen verborg het bericht in zijn binnenzak. Hij voelde zich niet sterk genoeg om naar de stad te gaan. Ook de vervallen rentebriefjes van de twee laatste trimesters stonden nog te ontvangen. 'Uitstellen,' dacht hij met jaloersheid en gemakzucht.

'Waar zijn mijn sigaren?' vroeg hij 's avonds, toen het lamplicht aangestoken was. Hij rookte ze wel zelf niet, maar tastte er somtijds naar met de voldoening van eigendomsbezit.

'Als ze maar dienen om weg te geven, mag ik ze ook,' antwoordde Feel, vrij bot. Hij wreef een lucifertje en begon er een te roken.

't Zijn de mijne,' sprak Bouwen bars, een schrede nader komend.

'Wij weten 't wel, het is hier al het uwe,' spotte Feel.

Bouwen struikelde over een kind, dat hij bijna omver liep. Het huilde en kliste zich aan hem. Hij ging weer in zijn hoek, als een verschrikte hond in zijn hok.

De kleine bleef tussen zijn knieën staan.

Het was hard, het was pijnlijk, hij moest hier veel verduren. Zo ging het, als men oud werd en zich niet meer verdedigen kon...

De bedrukte man keek naar de opwemelende rode sprankels van de schoorsteen, dansend hun dodendans.

'Elders gaan! hier weg zijn uit het bedwang en de bestendige vrees, o elders!' maar hij kon niet, het nodige daartoe ontbrak hem: de energie en de wil en ook nog zijn verknochtheid hield hem hier. Ondanks alles was het 
hem nog niet in de zin gekomen Trezeken en de kinderen niet als zijn erfgenamen te aanzien.

'Waarom zou ik een testament moeten maken?' had hij eens onvoorzichtig gezeid, achterrug, tegen de notaris, die, door hen aangezet, hem daarover sprak. 'Alles wat ik bezit is toch voor hen, zij hoeven 't maar te nemen na mijn dood.'

'En de erfenisrechten?'

'Wat weet de wet of het niet al verleefd is met die hoop van kinderen!'

Dit was hun overgebracht en van nu voortaan zagen ze alles aan als hun rechtmatig eigendom, en hem als de verheler van dat goed.

\section{XV}

Berzeel was thans een jongen van een jaar of acht. Hij wachtte reeds de koeien in de wei of in de elskant. De tweeling en nog een ander gingen school. De drie kleinsten bleven thuis onder de hoede van Bouwen, terwijl Trezeken en Felix op het land of in de stallen waren.

Uitgaan kon hij niet meer, hij was te oud; zelfs niet tot aan de kerk, hij kreeg zijn hoogdag (1) thuis. Maar werken moest hij thans: het kleinste wiegen, sussen, een prop in de mond duwen, als het schreide, de pap koken en erger nog - wat hem zozeer vernederde: aardappelen schillen!

Waar was de tijd dat hij gezag had, deftig en geacht! Zijn harte bloedde en jammerde, zijn krachten schoten zelfs te kort; maar geen genade was er voor 't gerecht van 't noodlot.

'Allo, paard, op, op!' maande hij zichzelf 's morgens aan, als hij zo gaarn had blijven liggen.

Raad werd hem niet meer gevraagd: de vruchten waren gezaaid of geplant, waar Feel het goedvond; op struik of staal verkocht naar zijn believen zonder mededeling ervan. Het pachtgeld werd hem gevraagd, geëist met gezagvoerend woord en dringende blik:

'Wij moeten toch enige vergoeding hebben om u uit te lichten (2),' had Feel eens geantwoord op de schuchtere aanmerking van Bouwen, dat hij geen pachter meer was.

En Bouwen had gehoorzaamd: het geld gegeven als een stukje van zijn ziel.

In den beginne, toen hij niet meer reizen kon, had de notaris voor hem de effectenbriefjes ontvangen; maar in zijn zucht naar verheimelijking had Bouwen niet alles meegegeven, wat vervallen was: 'Zodra ik zelf kan gaan, doe ik het; niemand behoeft te weten, wat ik bezit,' dacht hij.

(1) De communie door de dorpspastor gebracht worden.

(2) Iemand tot aan zijn einde onderhouden en in huis verzorgen. Allusie aan de lichtmiskaars die de zieltogende in de hand krijgt. 
Wel had de wisselaar aan de notaris gezegd, dat er meer coupons moesten zijn. Bouwen had tegen Felix, die het - ingelicht - overbracht, het hoofd geschud, ontkennend zonder een woord.

Overigens het waren zijn zaken. Geen mens had er iets in te zien.

Schielijk stierf de notaris.

En weer bleven de waarden onbetaald en weer kwamen er brieven, een aan Felix thans, dat zekere titels moesten uitgewisseld worden op straffe van verjaring en tenietgaan.

Bouwen was zelf ditmaal bezorgd.

'Ik zal u 't geld en de titels weerbrengen,' zei Feel, gekwetst door 't zichtbaar hem getoonde wantrouwen, 'wat meent ge dan dat ik zou willen wat het mijne niet is!'

Hij bracht hem inderdaad het geld, maar de titels waren niet klaar, daarvoor had hij een ontvangstbewijs van de wisselaar.

'Geef het hier,' zei Bouwen met gretigheid.

'Het steekt in de zak van mijn jas, morgen,' luidde het ontwijkend antwoord.

'Och, ik kan 't evengoed - en beter nog dan gij bewaren, ik moet het toch weer naar de stad meenemen,' ging het 's anderdaags.

Bouwen dorst niet aandringen.

En toen na enige tijd Felix de voorlopige titels in zijn bezit bekende te hebben, en weer het terhandstellen verschoof, tot hij de blijvende krijgen zou, verontrustte dit de oude man.

Hij zat in de opgedrongen plaats - de plaats der ballingschap onder zijn eigen dak - en zuchtte: 'Gelukkige mensen, die zichzelf behelpen kunnen!'

Meestal kwam hem die bekommernis op tegen de avond, wanneer de duisternis onder de lage keukenbalken binnenwolkte, de vlam traag en luierig opflikkerde, en hij door 't brede venster keek onder de kruinen van de naakte boomgaard, waar de scheidende dag nog een gele vingerstreep aan de grauwe horizon wreef.

Fik zat naast hem, heel dicht, in sympathiegevoel, ook melancholisch, met zijn blindwordende ogen halsstarrig naar buiten gericht.

Fik was niet meer de levenslustige hond van eertijds. Zijn haar stond schraal, grijs en borstelig op, hij was stijf, lamlendig en tandeloos. Oud, krachteloos en als zijn meester onderdrukt.

De kinderen kwamen nat, bemorst van de school thuis, de kleinsten schreiden, over de vloer lopend of hun moeder achterna, die naar de stallen melken ging met rinkelend akergeklets.

En Bouwen zon op een middel om in het bezit te treden van zijn eigendom.

Nooit, nooit meer zou hij iets uit zijn handen geven! 


\section{XVI}

En op zekere dag wist hij, dat Felix de effecten had, met zekerheid wist hij 't bij ingeving, ofschoon geen woord ervan te zijnen gehore was gekomen. Zij waren in huis, zij openbaarden hun verholen tegenwoordigheid aan zijn gescherpte geest. Hij wou en moest ze hebben, heden nog. Zijn oude energie herleefde als een dovend vuur, dat nog een laatste vonk uitschiet. Hij zou niet gaan slapen voor hij ze kreeg en heimelijk ergens bergen kon. Hij schoof het avondeten weg, dat Trezeken hem voorzette: overschot van 't maal der kleinen, half verknaagde en geweekte korstjes brood, lauwe pap. Hij had het sinds lang altijd aangenomen, als een hond die geen keuze kent.

'Mijn titels,' zei hij stout aan Feel, opstaande.

'Laat mij met vrede,' bromde deze.

'Mijn titels!' sprak hij nogmaals met verkropte stem.

'Om ze te geven, moet ik ze zelf eerst hebben, hein?' bood Felix hem het hoofd.

'Gij hebt ze,' bulderde Bouwen met de vuist vooruit op hem, stram, waggelend doch dapper toetredend, 'en geven zult ge ze, op staande voet, het zijn de mijne!' schreeuwde hij.

Feel stampte hem achteruit.

Bouwen, wiens lichaamskracht door woede weer tijdelijk was opgewekt, vatte zijn neef in 't midden van zijn borst bij zijn vest vast:

'Geven, geven!' tierde hij.

Felix stiet hem achteruit en, ook in toorn ontvlamd, gaf hij de oude man in volle borst een ontzaglijken schop, uit al zijn macht, met zijn lompe klompenvoet.

Een dubbel, kort gekraak als van een wagenwiel, dat over scherven rijdt, volgde op de stoot.

Bouwen werd akelig bleek en stortte met een gil ten gronde.

Fik vloog op Felix aan, met de muil zonder tanden greep hij zijn broekzoom vast. Een vuistslag deed hem jankend wegvlieden.

De kleinen waren allen in bed, maar twee bruine kijkertjes op kinderhoogte loerden nieuwsgierig en beangst door de donkere reet van de kamerdeur...

Trezeken was toegeschoten, helpend, steunend, oprichtend en nu had ze het tegen Feel: 'Lomperik, kolf!' (1) verweet zij hem.

Oom Bouwen werd door hen beiden gesleept naar zijn bed, zijn bed dat thans niet meer in de grootste kamer stond van het huis, maar in een ellendig hokje naast de keldertrap: laag, klein en dompig. Nauw nog was er voor de kast en voor de koffer plaats.

'Ha, ha!' klaagde de grijsaard en hoofdschuddend in uiterst smartbesef: 'de bol is ten einde gelopen, ten einde, ten einde!' steende ${ }^{29}$ hij.

(1) Woest mens. Gevaarlijk, onbeschaafd. 
Fik was op het bed gesprongen en zat gehurkt aan 't voeteneind in de verste hoek. Zijn ogen lichtten als de ogen van een kat en hij grolde de dekkende vingers van Trezeken aan.

En terwijl Felix, ontzet en radeloos, in de half duistere keuken zat met het aangezicht naar de grond gebogen, als versteend, achteloos voor wat er rondom hem gebeurde, werd een kleine hand op zijn knie gelegd. Een betraand aangezichtje, met bevend mondje en bevende kin keek hem aan. Felix schrikte hevig op:

'Berzeel!'

'Vader, ik heb alles gezien, alles, alles!' zei het kind in stille verslagenheid.

Mijn hemel! een getuige van zijn euveldaad!

'Ge droomt!' bracht Felix met verkropte stemme uit. 'Rap naar uw bed!'

'Ik heb gehoord en gezien!' hield het kind als een wraakgeest vol.

In onuitsprekelijke angst greep Felix zijn zoon bij de nek en sleurde hem, met meer geweld dan nodig was voor zulk een tengere kindergestalte, over de vloer. Met een korte ruk trok hij de grendel uit de deur van het achterhuis.

$\mathrm{Zij}$ waren buiten. Daar was het helder van de maan die op de daken, op de bomen en op de akkers scheen.

Dicht achter de woning, in een beschaduwde insprong, met een palmboom (1) erover, lag een teerput (2), smal van opening, drassig met een zwarte diepte, waarin het water van de dakpannen afdroop en het schotelwater ${ }^{30}$ wegvlood. Die put was met een blauwe steen gedekt sedert er kinderen op het hoeveken waren.

Felix hief het deksel bij de ring op en, woest, in de onberedeneerde overmaat van zijn beduchtheden, hield hij het hoofd van Basiel over de gapende donkerheid, het zelfs daarin naar benedenduwend, het kleine lichaampje schuddend daarover en, ofschoon hij het stevig vasthad, net zich aanstellend alsof hij het daarin werpen ging.

Basiel jammerde en schreeuwde, zich met de kracht der wanhoop, en de verdediging voor het levensbehoud aan zijn vader krammend.

'Zult ge nu nog zeggen dat ge iets gezien hebt stouterik?' vroeg Feel met gedempte woede.

'Neen, neen, vader, vader!' kreet het kind spartelend onder de ouderlijke vuist.

En hij liet het los, de steen weer met een plomp over de opening tuimelend.

'Hoor, zei hij in huis, schijnbaar kalmer tot de sidderende, doodsbleke knaap, 'indien ge ooit een woord rept over wat ge daar verteld hebt, smijt ik $\mathrm{u}$ in de put met de steen erop, zonder genade, verstaat gij het?' en zijn blikken vlamden met schrikaanjagende vastberadenheid.

'Neen, neen,' stotterde Basiel.

(1) Buksboom.

(2) Opslorpingsput. 


\section{XVII}

Trezeken bleef op bij Bouwen tot na middernacht. Zijn aangezicht, zijn oud, vermagerd, ingevallen aangezicht was heel ontstoken, blauwrood als een geverfd doodshoofd.

'Ik krijg het vuur in mijn lijf', klaagde hij, 'ik heb het vuur in mijn lijf!'

Zij had een emmer met koud water aangebracht, en legde natte doeken op zijn borst, waar een grote plek zwartachtig blauw werd en al meer en meer opzwol.

En telkens kwam er een kleine verlichting in zijn pijn. Toen barstte hij weer uit:

'Het is alsof er met messen in mijn lijf gestoken wordt; ik heb het vuur in mijn lijf!' kreet hij luid.

'Toe, toe,' suste hem Trezeken.

Maar Trezeken was vermoeid van een lastige dag arbeid, ondanks zijn jammerklachten ging zij heen, eens even luisteren of haar kleinste niet wakker was, en nauwelijks teruggekeerd bij hem, geloofde zij dat het schreide, wat het ook deed, een hele poos. Zij ging weer weg en aaide en paaide het en begaf zich toen zelf te bed.

'Verlaten! hulpeloos!' kreet Bouwen, terwijl twee dikke tranen langs zijn stoppelige wangen rolden.

't Is een schande dat men mij hier aldus liggen laat!' En alsof Fik de beduidenis van die klacht verstaan had, sloop hij nader en likte zijn meester in het aangezicht.

Heengaande had de verpleegster de emmer met koud water op een stoel bij haar ooms bedstee gezet, wellicht reeds met het heimelijk inzicht niet meer weer te keren.

In een uiterste krachtsinspanning richtte Bouwen zich half op, stak de arm uit, en preste het in 't water liggend linnen met de hand droppelend uit om zijn stekende pijn te verzachten. Een tweede keer kon hij 't niet en in de oproer der vertwijfeling riep hij luidkeels: 'Treze! Treze!'

Niets bewoog in het huis.

'Treze! Treze! Treze!' herhaalde hij, steeds de stem verheffend als een razende.

Een lompe stap kwam door de keuken, en in de opening van de kamerdeur verscheen Felix dreigend met de vuist:

'Wilt ge wel zwijgen, kalf! Alzo onze ruste storen!'

Bouwen kromp ineen onder dat dreigement en die blik.

Feel was weer weg: door 't aan zichzelf loochenen der bedenkelijkheid van de toestand, verminderde hij welgevallig eigen schuld.

En wederom alleen lag Bouwen.

Maar nu ruiste er iets naderbij, als het gewriemel van een muisje over de vloer.

Even piepte de dichtgetrokken deur. 
Basiel stond voor het bed.

'Mijn kind, mijn kind!' murmelde Bouwen, een hand, vasthoudend, op het lage schoudertje drukkend:

Een reddend engeltje dat troost en lafenis bracht!

Met zijn kleine vingertjes legde Basiel, volgens gekregen aanduiding, de natte doeken op de kneuzing en toen wachtte hij, op een stoel gezeten, de korte beentjes opgetrokken en de voetjes op de sport, enkel van tijd tot tijd vragend: 'Doet het nog zo zeer, Bouwen-oom?'

Er scheen verpozing in te treden.

'Kom eens hier,' sprak Bouwen eensklaps, ofschoon het kind buiten bereik van onbescheiden luisteraars dicht bij de sponde zat.

'Gij hebt het gezien, nietwaar, Basiel?' vroeg hij, met koortsgloed in de blik; want voor zijn verhelderd visioen verschenen in een halfduistere deurreet twee nieuwsgierig kijkende kinderogen, onafscheidbaar voor hem van de gruwlijke gebeurtenis, duidelijk opgemerkt voor hij de doodsstoot kreeg. Basiel huiverde, want voor zijn eigen herinnering doemden op zijn toornige vader, de donkere rand, de wreed geleden stervensangst...

Zwijgend boog hij het hoofdje; hij hoorde 't nog: 'Indien ge ooit een woord daarover rept, smijt ik $\mathrm{u}$ in de put met het deksel erop...!'

Hij dorst niet spreken.

Oom Bouwen hield vol: 'Gij stondt erbij, ik weet het,' zei hij, 'maar 't aan niemand zeggen, hoor, aan niemand, niemand, van geheel uw leven niet... voor de eer van de familie,' fluisterde hij nadrukvol.

De kleine schudde 't hoofd, dat hij 't verhelen zou. En het was alsof Bouwen naar die enkel door een teken uitgedrukte belofte gewacht had voor 't plechtig en beslissend ogenblik, dat er een ontzagwekkende sterkte aan bijzette: een rochel kwam in zijn keel, zijn oogleden vielen toe, en een akelige bleekheid verspreidde zich over zijn gelaat.

Zien sterven is een enig iets, wie 't nooit heeft bijgewoond, weet toch dat het gebeurt, weet het met zekerheid, met bevend hart, met lamheid in de armen, met ontzetting in de trekken.

De kleine knaap stiet een gil uit en vluchtte weg, naar zijn kamer, in zijn bedje, de deken trekkend over zijn gelaat, waarop het koude zweet uitbarstte.

\section{XVIII}

Bij 't eerste morgenschemeren vonden ze hem. Trezeken was tot aan de deur van de slaapkamer gegaan, loerend, luisterend. Zij merkte geen beweging in de twijfelklaarte, hoorde geen gerucht. Een paar maal riep ze heel stil, bevreesd voor het geluid van eigen stem:

'Onkel Bouwen - Onkel Bouwen!'

Geen antwoord kwam. 
'Och Feel, sta op; ik durf alleen niet in de kamer gaan, hij spreekt niet meer, och Feel, ik ben zo bang, zo bang!'

Hij sprong uit het bed, trok enkele kledingstukken aan en ging mee, samen aarzelend nog aan de kamerdeur, - en toen ineens beiden naar binnen.

$\mathrm{Nu}$ schrokken ze voorgoed: daar lag hij dood, reeds half verstijfd, oom Bouwen.

En met verslagenheid keken ze elkander aan, stom van ontroering en van bange voorgevoelens:

'Vermoord! vermoord!'

In zijn fantasie zag Felix ook twee kinderogen, onbescheiden getuigen van de wandaad, hoorde hij een fijne, stoute stemme van beschuldiging... zulk een geducht geheim, bewaard in een zo licht geopend jongensmondje!

Geen enkele stond van ruste meer voor hem!

Er viel geen tijd te verliezen. De toestand was wanhopend schier: de veldwachter, gendarmen, 't volksgedrang...!

De geest van 't praktische nam schielijk de bovenhand. Als door een vreemde macht bestierd haalde Trezeken linnen; in overijlde haast hielpen ze malkander de vuile plunje van de gedode uittrekken, een lap op de vreselijke kneuzing houdend om ze niet als een aanklaagster te moeten aanschouwen; en met vereende en verdubbelde handigheid sleurden zij het lijk over de grond tot in de keuken. Aan de pompsteen op een groten hoop aangebracht stro, waarover een fris wit laken was gespreid, werd het neergelegd, met de armen op de borst gekruist, een palmtakje tussen de vingeren.

Dat gebruik was in het dorp, en zelfs in de landelijke buurt uit de mode: de overledenen bleven in hun bed thans; maar daar hadden de ouders gelegen, vervolgens Zalia en dan ook Sarelken. Uit gewoonte legden zij er oom Bouwen.

Wanneer de verbaasde kinderen opstonden, was alles reeds in orde. Nauw was het volle dag. Dra spreidde het nieuws zich rond.

De naaste buren kwamen:

'Zo schielijk!'

'Gisteren heb ik hem nog op de boomgaard gezien!'

'En ik heb nog in 't voorbijgaan tegen hem over de haag geroepen!'

Trezeken vertelde: 'Het is precies gebeurd als met Sarelken, gezond gaan slapen en 's morgens doodgevonden. Hij had het borstwater, zulke mensen zijn ineens weg.'

De huisdokter was op zijn ronde, hij had het nieuws gehoord, hij zag het aanduidend strokruis met de baksteen erop voor 't hek liggen. Fluks wipte hij van zijn fiets.

Toen hadden zij alweer een grote schrik.

Trezeken was zo wit als de dode zelf. Haar wangen schenen weggekrompen, haar ogen stonden strak en wijd. Felix hield zich schuil, zijn gelaat onder de duisterheid van de schoorsteen verbergend, sprakeloos, ademloos. 
'Zo, zo!' en hij stelde meer vragen, de dokter, even 't laken over 't lijk opheffend, een hand op de gekruiste handen leggend, op de borst juist boven de kneuzing! daar eens kloppend, schuddend aan de stijve gestalte, die op heel haar lengte bewoog.

Trezeken herhaalde nauwkeurig de geschiedenis van Sarelkens dood; dat haar stem toonloos klonk en beefde was niet vreemd na zulk een treffende gebeurtenis.

De dokter sprak hun voor de vorm enige woorden van moed in, welke hij zelf in de gegeven omstandigheden volkomen overbodig vond.

Het was als werd er een molensteen van hun hart weg gerold, toen zij hem voortwielen zagen: 'Goddank! Godlof!'

Het was nu zelfs beter dat hij gekomen was; maar welk een ogenblik van helse kwelling, welk een angst! 'O Feel, toen hij dat laken ophief en tastte juist op...'

'Zwijg, zwijg,' zei Feel, met de hand stilte wuivend, 'geen woord daarover meer, het is al te verschrikkelijk!' en hij verborg zijn aangezicht onder zijn tien vingeren.

Hoe lekt iets uit, waar nooit de mond van heeft gesproken, wat geen burenogen hebben gezien?

Was het misschien het ongewone feit, dat de huisgenoten zelf de overledene hadden af- en op zijn stro gelegd?

Wie zal het zeggen. Doch gemurmeld werd er over dit zo plotseling verscheiden. Vermoedens werden heimelijk uitgedrukt. En degenen, die 's avonds om zes uur de rozenkrans bij 't overblijfsel van Bouwen gebeden hadden, fluisterden heengaande langs de duistere wegen:

'Hij is er zo verdrukt geworden.'

'Wie weet wat er met hem gebeurd is!'

'Hij zal niet weerkomen om het ons te vertellen!'

Tot openlijke aantijgingen of tot een enkwest kwam het niet.

Met de begrafenis werd er spoed gemaakt. Reeds 's anderdaagsmorgens lag Bouwen op het kerkhof.

\section{XIX}

Des avonds van die dag, toen de kinderen slapen waren en het reeds laat genoeg was om geen bezoek meer te duchten, zei Trezeken:

'Feel, indien wij nu eens keken?

'Ja,' antwoordde hij, maar hij draalde nog.

'Kom,' en zij nam de lamp. Het tochtte door de reten en onder de deuren en de vlam laaide dansend op, door de beweging van haar stap.

In 't hokje waar oom Bouwen sliep, lag nog het bed verward, met de inprenting die zijn hoofd in het kussen had nagelaten.

Met de sleutel opende Feel, op een knie gezeten, de grauwe, ongeverfde koffer: 
'Alzo een pak!' riep hij gretig juichend uit, de effecten met een koord saamgebonden eruithalend. Zijn blik schoot een lichtstraal naar Trezeken op.

't Is voor onze kinderen,' zei zij - die eeuwige ontschuldiging der ouderen voor elke loense daad, voor al wat hebzucht, gierigheid of onrechtvaardigheid zich onderstaan ${ }^{31}$ te doen.

En in de keuken bij de neergezette lamp, die al de hoeken in het donker liet, werd onder de ronde kring van 't licht, het pak ontvouwd, met stijve vingers, trillend van begeerlijkheid, elk stuk ontplooid.

'Die hondsvot!' brieste Feel ineens met een hele reeks van vloeken; en hij sloeg een greep van titels met geweld tegen het tafelblad.

'Hier, hier! de schuldbriefjes van jaren hangen er nog aan; vervallen, goed om in 't vuur te werpen. Die schelm, die...'

'Zwijg, zwijg!' bad nu ook Trezeken, zoals hij haar in 't bijzijn van het lijk de dag tevoren had gebeden, 'zwijg!' en zij keek verschuwd in de richting van de pompsteen, waar op de donkerblauwe schorren ${ }^{32}$ nog enkele stropijltjes slingerden, glimmend als vonkjes van 't geweten in het schijnsel van de vlam, stropijltjes van de bundel, waarop 't lijk van oom Bouwen gelegen had.

's Anderdaags om elf uur brak de schooljeugd luidruchtig uit het poortje, dat op 't kerkhof uitgang had, stoeiend, joelend, kibbelend, zonder eerbied voor het veld der dood, gewend aan de kruiskens, de zerken en de graven.

'Kijkt eens!' riep er een. En allen zagen toe:

'Een hond, wat doet hij daar?'

Geweldig scharrelde deze met de dubbele kracht van zijn bijeengehouden voorpoten op een vers terpje. Hij scharrelde zo dapper, zo geweldig, dat het gele zand, met dorre beendertjes en schilfertjes vermolmd kisthout meters verre achter hem uitvlogen.

't Is onze Fik,' zei Basiel.

'He, wat een lelijke, ruige hond!' riep er een.

En een ander met jongenshanden, jeukend reeds om kwaad te doen:

'Indien wij nu een steen hadden om ernaar te gooien of een sneeuwbal maken konden, hoe zou hij vliegen!' zei hij met verlevendigde blik.

Het paadje, waar zij op uitbrokkelden, was met een ijzeren tuintje op heel zijn lengte van de begraafplaatsen afgescheiden.

'Kon ik erbij, ik zou hem schoppen,' sprak een kleine guit, geen drie voet hoog.

'Maar kijkt toch eens!' herhaalden zij.

De hond had reeds niet alleen de helft van het terpje weggekrabt, maar een hele put in de aarde daaronder gemaakt.

Basiel had de begraving bijgewoond: 'Ginds ligt oom Bouwen,' zei hij 
gewichtig, als aan de grond genageld door de aanblik van die ijver en onzinnige moed.

'O Bouwen, Bouwen Velghe!' tierden zij, 'de grootste gierigaard van heel het dorp.'

'Een die niet eten dorst!'

'Een die een cent in twee beet!' -

'Van honger dood, met al het geld in zijn kas!' Zij spraken allen door malkaar, Basiel omringend, enkelen dicht onder zijn neus met de ene vinger over de andere schrappend. ${ }^{33}$ Het was om hem te tergen, hem te sarren, dat ze 't deden; maar hij nam het ernstig op:

'Het is niet waar, het is niet waar', herhaalde hij bijna schreiend, overmand.

't Is zeker waar, 't is zeker waar!' hielden de bengels vol, thans guitig om hem heen springend.

En in zijn kinderverontwaardiging over het lasteren van zijn bloed, ontsnapte 't hem gewichtig en beduidenisvol:

'I $k$ weet waaraan oom Bouwen gestorven is.'

Toen kromp hij zelf ineen van schrik: de put, zijn vader met het deksel in de hand...!

De jongens zwegen, heimelijk aangedaan door iets beklemmends, hartbenauwends, iets hachelijks, iets verholens, zwevend in de lucht...

'Fik, Fik, kom, Fik!' riep Basiel, de hond tissend, ${ }^{34}$ op zijn broekspijp slaande, 'kom, manneken, spring over het tuintje, kom!'

Maar Fik bleef wroeten op het graf van zijn vermoorde meester.. 




\section{VRIJHEID - BLIJHEID}

Een stamp werd op de voordeur gegeven - een grote stamp als een vuistslag. Buiten regende het met stromen.

En aleer vrouw Rogiest tijd had om ijlings vanuit de verre keuken door de gang en de winkel te lopen openen, bonsden er nog een paar slagen met driftig ongeduld tegen het hout aan.

$\mathrm{Zij}$ beefde van ontsteltenis.

Haar man trad binnen, zijn parapluie buiten uitschuddend, en dan het water langs de panden van zijn jas met de hand naar beneden slaande.

Hij was druipnat.

'Welgekomen, vader', zei ze, wat ze altijd zei als hij thuiskwam.

'Is dat een mens laten staan, in zulk een hondenweer,' verweet hij korzelig.

Zij dorst niet tegenspreken, zij wist dat ze niet mocht, wilde zij hem niet heftiger doen opvliegen.

'Kom binnen, vader. God wat zijt ge gesteld', zei ze met schuchtere vleierij van ootmoed.

'En hoe zoudt gij het aanleggen om droog thuis te komen door alzo een stortvlaag? Hé, hoe zoudt gij het doen?' tergde hij haar, wel besloten van een der vreugden van het familieverkeer - namelijk zich aan een vlaag van slecht humeur overgeven - gebruik en misbruik te maken.

' $t$ Is dat ik zoveel medelijden met $u$ heb,' waagde ze te zeggen.

Ditmaal antwoordde hij niet, volgde haar in de keuken.

Daar zat de vrouw van de onderwijzer. Zij stond verlegen op, trachtte zich zo klein mogelijk te maken en sloop met een gefluisterd: 'Goeden avond' aan haar vriendin achter zijn rug weg.

Hij stelde zich alsof hij ze niet opmerkte. Hij had geen lust tot groeten of om een gesprek aan te knopen.

Vrouw Rogiest dorst de bezoekster geen uitgeleide doen, en liet ze alleen vertrekken.

Het gerucht van de, met een bescheiden rukje toegetrokken voordeur, deed hem - schijnbaar verschrikt zich omkeren:

'Wat is dat?'

'Vrouw Pauwels die weggaat.'

'Die babbelaarster! was ze hier weeral?'

'Zij hield mij gezelschap, zij weet, dat ik bang ben als ge laat uit zit en de kinderen slapen zijn.'

Daar had ze zich opnieuw versproken, nu kreeg zij het: 'Ha! het is zeker voor mijn pleizier dat ik uitzit. 't Is prettig nog verweten te worden, als men 
zich dood afslooft. 't Is verkwikkend aldus thuis te komen!'

'Vader, wat wilt ge eten? Ge hebt toch elders niet gegeten, zeker?' op bange toon.

'Zo, zo! Ik zou elders moeten eten, wel wel! wat zal men nog horen!' zei hij.

Middelerwijl had hij zijn overjas uitgesleurd, toeschietelijk schuw 'geholpen' door zijn eega. Nu trok hij zijn schoenen uit en wierp ze in een hoek. Zij stond gereed met de droge sloffen in de hand, gebogen als een slavin, die zich in de tegenwoordigheid van haar gebieder niet recht houden durft.

En hij zat neer aan de dis in de gezellige keuken naast de hete kachel, waarop de waterketel zijn huiselijk liedje zong, bij de hellichtende petroleumlamp met vork en mes en zijn lievelingsschotel voor zich staan.

Hij was een flinke, kloeke man - in de veertig, met nauwelijks grijzend haar, een gezonde blos, thans nog verhoogd door zijn doorgestane worsteling tegen de elementen. Zijn lippen waren dun, nijdig saamgeperst. Zijn mond scheen niet te kunnen lachen.

'Vader, het smaakt u', zei ze juichend, ziende dat hij dapper vork en mes hanteerde en een goede teug bier dronk.

'Ja, het smaakt mij inderdaad', antwoordde hij, ditmaal de strijd opgevend.

'En hoe hebt ge het gesteld?' vroeg ze, met de ellebogen op de tafel leunend, de mouwen op de magere polsen werkzaam achterovergeslagen, gretig benieuwd hem aanstarend, met nog iets van liefde en bewondering in het verdoofd oog. Zij was ontvleesd, neergedrukt, verkleind en gekrompen voor de tijd: een jammerbeeld, ofschoon nog enige jaren jonger dan hij.

En nu gaf hij bescheid met de mond vol: Hij was bij boer De Wilde geweest, immers voor dat zieke paard, - hij was veearts - Vlieger had de plaag in zijn koestal!

'God in den hemel!' riep zij, hem onderbrekend met de handen saamgeslagen.

Ineens zweeg hij, licht geraakt.

'En dan, vader?'

'En dan? Ik weet het niet meer, ge laat mij niet uitspreken. Ik heb de draad van mijn gedachten verloren.'

'Van die plaag bij Vlieger, vader.'

'Twee doen afmaken,' zei hij.

Zij dorst niet verder vragen.

'Drie varkens gekocht, bij Lathauwer,' berichtte hij, 'slekkevet,' tachtig centimen de kilo, levend opgewogen.'

Dat was een kleine prijs voor vette varkens; maar zij waagde geen opmerking.

'Niet goedkoop genoeg misschien?' hernam hij, strijdvaardig tegenover zijn altijd overwonnen wederhelft, die hij als een bestendige tegenstreefster behandelde.

'Mij dunkt dat het niet veel is, vader.'

'Zo, zo, het dunkt u maar. Ge zijt er dus niet zeker van', herbegon hij te vitten. 
$\mathrm{Nu}$ zuchtte zij, onweerhoudbaar diep. In het begin van haar huwelijk had zij geweend, als hij haar aldus met speldeprikken trof, nu was de bron der tranen opgedroogd.

'Vader, ik heb slaap,' zei ze, haar zucht in een gemaakt geeuwen dadelijk omwerkend.

'En ik zeker niet?' sprak hij bitsig.

\section{II}

Zij was met hem uit liefde getrouwd. Zij was toch een bemiddelde wees, teer van gevoel en tenger van gestalte, fijn van gelaat, beschaafd van geest, zacht van gebaren. Zijn uiterlijk schoon had haar bekoord, zijn innerlijke tekortkomingen had ze niet opgemerkt. In zijn thuis, bij zijn ouders, had zij hem nooit gezien. Zeer verzorgd op zijn persoon destijds - iets waarvoor geen enkele vrouw onverschillig is - was hij voor haar steeds verschenen. Hun verloving was daarenboven kort van duur geweest; zij nauwelijks uit de kostschool bij verwanten vertoevend, had hij om haar gunsten gedongen. Een meisje met geld wordt te platten lande zeer gezocht. Meer dan één partij had ze op die weinige tussentijd van de hand gewezen. Hij was de gelukkige, of liever zij, want nu ging, voor haar, de ouderloze, een levenszon van goud en purper op, een toekomst zonder wolk of stormenmogelijkheid. Jong, mooi, zoals ze zich bewust was, welhebbend, gezond, verliefd, bemind, wat kón haar nu nog deren van het lot?

Helaas! helaas! ontgoocheling volgde op ontgoocheling: eerst vermoed, ontkend bij zichzelf en toch smartelijk waargenomen, eigen schuld van prikkelbaarheid oorzaak wanend, strijdend innerlijk, met het element der werkelijkheid, bekappend 't licht dat haar gescherpt oordeel verhelderde. Neen, neen, zij wilde, zij mocht zijn fouten niet zien, - hebben wij niet allen de onze? - Doch haar fijngevoeligheid werd voortdurend gekwetst, haar kiesheid beledigd. Tonelen van schreibuien, van liefdeverwijten, verzoeningen, onbevredigd, oppervlakkig, hadden plaats tussen hen, totdat eindelijk, ineens - als een sluis, die lang toegehouden, en plots opengeschoven, het hoge water met onstuimigheid doorlaat, al haar wrok, al haar grieven tegen hem, ontoombaar losbraken in een inwendige storm van opstand, onloochenbaar en zonnehel... Ja, ja, zij had zich vergist, hij was de man van haar keuze, niet de man naar haar hart...!

Zij propte al haar teleurstellingen op, klaagde niet meer, eiste niets meer. Een onvrijwillige, stoffelijke aantrekkingskracht alleen bleef nog bestaan voor hem; een fierheid ook naast hem, de flinke man in het openbaar te verschijnen; maar vooral een ontzag, een bange vrees voor zijn boze buien, een onverwinbare schrik voor de huistiran. Er was een soort van beklemdheid in zijn bijzijn, die zij nooit overmeesteren kon.

De geboorte van twee kinderen, een zoon, Stanislas, en een dochter, 
Elvire, brachten afwisseling. Gemeenschappelijk belang in hun ontwikkeling, gemeenschappelijke vreugd en pret over hun grappig en liefkozend doen, en zorg in ziekten of tijdelijke zwakheid, gaven toenadering.

Dit duurde niet lang. Zodra een kind naar de school gaat, is het naïeve, het uitsluitend bezit voor de ouders ervan af. Het kind vangt als zelfstandige mens zijn eigen leven aan, maar het moet nog geleid, terechtgewezen worden. Hij deed het brutaal, zij met zwakheid. Nieuwe oorzaak tot onenigheden.

Toen zij trouwden, betrokken zij een klein, net gesloten huis in haar geboortedorp, het schoon gelegen Diependale. Met haar fortuintje en wat hij verdiende als veearts, konden zij stil doch goed leven.

Zijn ouders hadden een varkensslachterswinkel te Vroden, een handel die voorspoedig ging. Zij stierven beiden kort na elkander, door de influenza, die gene winter hevig woedde, weggemaaid.

Hij was een enige zoon. De gelegenheid bood zich - zijns inziens - te gunstig aan om ze te laten ontsnappen. En ondanks haar protest, haar nog eenmaal luid uitgesproken tegenzin, haar oproerig vooruittreden zelfs, behaalden zijn sterkere wil, zijn ruwe karakterkracht de zege, en het gezin nam zijn intrek in de door haar gehate slagerswinkel.

Dat was de laatste stoot, die al haar geestkracht brak.

Het nette huisje met zijn bloemen voor het raam, met de sneeuwwitte gordijnen, met de blinkende koperen belknop en de blinkende trekkers, ${ }^{2}$ dat was haar heiligdom, het nestje dat ze zelf kunstig en keurig ingericht had. Hij woonde om zo te spreken bij haar in. Het was haar tuintje, waarin de rozen en de achtuurbloemen ${ }^{3}$ zo overvloedig bloeiden, waarin geen kruidje wassen mocht, waarin geen steentje of stukje glas of afgevallen kalkstukje geduld werd.

Gans anders was het hier te Vroden. Van zodra zij de voet in zijn ouderlijk huis had gesteld, oefende dat huis zijn macht over haar uit. De ganse omgeving overmeesterde haar; de krachten schoten tekort om er tegen op te staan.

Hier was zij geheel uit haar element. Hij geheel in het zijne. Het huis zelf droeg er als 't ware toe bij - niet alleen om haar zedelijk maar ook stoffelijk te onderdrukken. Het was laag van zoldering, met een diepe tred in, als zonk men bij het binnenstappen in een put. De straat moest eertijds opgehoogd zijn, nadat het er stond. Het was oud, bouwvallig, groot en woest. Gauw was het er donker in de winter. De vensters op de voorgevel waren schier alle ongelijk van grootte, onregelmatig verdeeld. Hoe was het mogelijk daar bloemen te kweken aan de schaduwkant dan nog, eer van nette gordijnen te halen achter die groen- en blauwachtige ruiten? Wat het nog gestuikter, ouderwetser - zonder het bekorende van ouderwetse dingen -, deed schijnen, was het onlangs splinternieuw daarnaast opgericht schoollokaal, in rode bakstenen, met ruime, luchtige ramen. Een oorzaak tot voortdurende kwelling van vergelijkingspunt voor de ontevredene. 


\section{III}

Zij had een hekel aan dat slagersberoep. Het was haar onmogelijk zich te gewennen aan het zien van de varkens. Zij keerde het hoofd af, wanneer de kar er met een door de poort op het voorhof reed, en zij sidderde aan al haar leden bij zijn geschreeuw, als het afgeladen werd. Het lag telkens - voordat het geslacht zou worden - een dag en een nacht op stro aan de achterdeur en zij wachtte zich wel eraan voorbij te gaan. Des morgens als Vaas, de knecht, die er sinds vele jaren woonde, zijn schort aanbond en zijn mes wette, nam zij Stanislas en Elvire bij de hand en ging met hen in haar slaapkamer staan, de deur dichtgesloten. Zij stopte de oren en vernam toch nog bevend het noodgehuil. Eerst toen alles over was, kwam zij weer met de kleinen te voorschijn.

Rogiest schimpte nijdig met haar gevoeligheid, die hij aanstellerij noemde. Maar ofschoon hij haar niet dwong bij de wekelijkse terechtstelling aanwezig te zijn, toch eiste hij dat zij een werkzaam deel aan de voorbereiding en het debiet ${ }^{4}$ nam. Zij moest de sopketel schuimen in de voor haar zintuigen walgelijken reuk van 't vet. Zij moest de ajuin stoven voor de bloedworsten, ham snijden aan de toonbank voor de wachtende klanten, en het gehakt vlees, koel-dood voelend onder haar vingeren, door een blikken trechter met de duim in de snaar duwen.

Zij klaagde niet, zij sprak niet tegen, als hij iets gebood te doen, waarvoor zij weerzin had. Een wraak, een enkele negatieve veroorloofde zij zich te nemen: nooit at ze varkensvlees. Haar kinderen volgden haar voorbeeld en vader zat alleen voor de karbonaden, die hij met opzettelijke overdrevenheid zeer lekker prees. Hij ook nam wraak: op de dagen, voor 't eten van zwijnevlees bestemd, duldde hij geen ander vlees op de tafel:

'Ge kunt nu op de haspel blaffen, (1)' zei hij. In het begin had zij pogingen tot hervormen aangewend: 'Vader, het geld ligt daar wel, laat ons het huis optrekken, het ruikt hier verduft, het is er vochtig en kil. Wij zullen er zo van genieten!'

Hij keek ontevreden op en antwoordde bars: 'Nooit. Mijn ouders hebben hier gewoond en zijn er tevreden geweest, wat voor hen goed genoeg was, moet het voor ons en onze kinderen wezen.'

Zij zweeg. Zij dorst niet zuchten zelfs in zijn bijzijn; maar het kruidje van de haat wies ${ }^{5}$ in haar hart en tierde er al weliger en weliger. Veronderstellen dat ze niet met hem getrouwd zou wezen, kon ze niet, hun levens waren te zeer in elkander vergroeid, zij had hem te jong gehuwd, te lief gehad daartoe, zij berouwde het niet, zij kon haar lot niet anders dromen, maar leed oneindig onder de gesel van die lotsbestemming.

Gedachten ontstonden in haar, als zondig weggeworpen dra: 'Rogiest is zes jaren ouder dan ik, volgens de loop der natuur zal hij mij voorgaan.'

(1) U te vergeefs ergeren. 
Zij kon 't niet helpen, ze drongen zich aan haar op, onverdrijfbaar, hardnekkig weerkerend: 'Er zijn veel meer weduwen dan weduwenaren, elk bereikt niet het uiterste punt van zijn levensloop. Sommigen worden in de bloei der jaren weggerukt...'

Toen rees zij ijlings op met een gevoel als wilde zij zichzelf ontvlieden en sloeg een kruis: 'Heer, vergeef het mij, ik wens niet naar zijn dood.'

Maar de wens lag ondanks haar in het verlangen naar vrijheid: 'God, goede, barmhartige God, laat hem leven, zolang hij kan; maar laat mij hem overleven, vergun mij zes jaren - de jaren, die hij meer telt dan ik - zes jaren nog, wanneer hij heen zal zijn, zes jaren vrijheid en verademing! Maar indien ik, ikzelf eens... voor hem...?'

Zij kromp ineen bij de gedachte, het hart in opstand tegen zulk een gruwlijke veronderstelling.

'Neen, neen, God zal en kan toch niet zo onrechtvaardig wezen!'

\section{IV}

Het regende nog immer des anderdaags morgens. Rogiest bleef bij de kachel zitten. Hij klaagde van stijfheid in de benen, stramheid in de rug. Wanneer hij aldus - bij uitzondering - thuis bleef, was het verschrikkelijk voor haar: 'Moet ge zulk een gerucht maken als ge kolen schept? moet ge er zoveel opeens insteken?' - 'Doe die deur dicht, ze staat altijd met een spleet op mij te trekken.' - 'Hoort ge niet dat er iemand in de winkel is, het belletje heeft al tweemaal geklonken.'

Zij ijlde er heen. Het was weer de vrouw van de onderwijzer; zij kwam om water, omdat hun eigen drinkwater niet goed was. Zij kwam zelf met de kruik, omdat ze graag een praatje maakte.

Hij kon wel beleefd zijn, als hij wilde. Ditmaal was hij het, misschien uit schuldbewustzijn tot goedmaking van zijn lompheid van de vorige avond.

'Zet u, juffrouw Pauwels,' zei hij.

Schuchter bleef ze staan, geen mens gevoelde zich ooit onbeklemd in zijn bijzijn.

'Neen, baas Rogiest, dank u, ik heb haast, de meester wacht, hij drinkt altijd water aan de tafel,' berichtte zij hem, niet wetend wat te zeggen in haar verlegenheid. 'Slecht weer', hernam ze: als twee mensen elkaar ontmoeten, spreken zij altijd van het weer.

'En gisteren dan, ik heb het al op mij gehad!' zei hij gewichtig.

'Hij kwam zijpend nat thuis,' wierp zijn vrouw hier tussen, het pompen stakend, gelukkig reeds dat hij hoffelijk was.

'Ik was om twee uur uitgegaan,' hernam hij, ietwat luider, 'het druipelde eerst wat, zo weinig, dat ik mijn parapluie niet opendeed; maar toen ik aan de Zompelingen kwam, regende het al ferm en ik...'

'Hij moest nog naar de Karmhoek en het Peperhol', hielp hem zijn vrouw. 
'Natalie zal 't u vertellen, zij weet het immers beter dan ik', sprak hij op slepende toon, eensklaps korzelig, en daar zij onthutst zweeg, tergde hij haar:

'Waarom vertelt gij 't niet wat mij is wedervaren? Allo toe, zeg het aan vrouw Pauwels.'

'Maar vader toch, ge moogt dat zo niet nemen,' ontschuldigde zij zich.

'Ha, ha! Ik zou u zeker nog moeten bedanken, omdat ge mij in de rede valt, zodra ik de mond opendoe.'

Een algemene beklemdheid zweefde over de groep. Gelukkig kwamen de twee kinderen van de school. Eerst luidruchtig binnen, dan schielijk blo, en kout en lachen stakend, toen zij zagen dat vader in de keuken zat.

Vrouw Pauwels maakte van de gelegenheid gebruik om met een 'dank u' heen te gaan. Haar vriendin vergezelde haar tot op de drempel. Zij uitte geen woord, maar de lijdensuitdrukking op haar verslenst gelaat was zo welsprekend, dat vrouw Pauwels troostend een hand op haar arm legde en zei: 'Och kind, elke man heeft zijn wolventand. Eenieder moet zijn zot kennen,' voegde ze er wijsgerig bij.

'Een slecht karakter leert men nooit kennen,' klonk het treurig antwoord. Het was de eerste maal dat vrouw Rogiest een zinspeling op haar onheil maakte.

O, weduwe worden! vrij zijn als de vogel uit een kooi ontsnapt. Gaan waar men wil, kopen wat men verlangt! Niet bestendig terechtgewezen, misprezen worden!

Zij betrapte zichzelf op dromen voor de toekomst: 'Indien ik meesteres ware, zou ik de varkenswinkel overlaten, het huis doen opbouwen hier, of naar Diependale in ons voormalig woninkje gaan. Genieten zou ik van het leven. Ik ben nog jong, ik heb nog zo vele, vele jaren voor mij!'

'Zwijg, zwijg!' sprak toen de stem van haar geweten, 'zwijg, denk dat niet.'

Zeg aan de beek, dat ze niet stromen mag. Zeg aan de bladeren in de herfst, dat ze op de bomen blijven moeten; aan de wind, dat hij niet huilen mag...!

Zullen zij, kunnen zij aan uw bevel gehoorzamen?

\section{V}

Stanislas was veertien jaar.

Elvire telde er twaalf en een half. Zij waren beiden groot voor hun leeftijd, bijna de kinderschoenen ontwassen. En een angst borrelde in de moeder op, een bedruktheid voor de schrikbeelden die hun toekomst bedreigden.

'Moeten zij in dit midden van grofheid, verstoken van elke beschaving, beroofd van elke geestesspijs, hun dagen slijten?' Was er in dit huis niet genoeg aan één misdaad van verdrukking, op haar gepleegd?

Zouden zij, zij ook gedoemd wezen tot de hel in het huwelijk? de offers worden van andermans grillen en moeilijke omgang? 
O! ze vrij te waren daarvoor, hun een onafhankelijk bestaan te verschaffen, dat werd haar tweede toekomstdroom. Voor de bemiddelde buitenmens, die niet met zijn handen, maar met zijn hoofd werken wil, bestaat er doorgaans maar één vak: dat van dokter voor een knaap, dat van onderwijzeres voor een meisje. Haar lotsbespiegelingen werden dus niet gehinderd door de twijfel van een keuze. Stanislas zou arts, Elvire schoolmeesteres worden. Om deze laatste vooral was het haar te doen. Geen juk zou haar knellen. Zelfstandig kon ze dan door het leven gaan.

Meer dan eens had ze in die zin gesproken, aan een dovemansdeur geklopt bij de alleenheerser.

'Stanislas moet slager worden, Elvire moet arbeiden in huis, aldus ontsparen wij werklieden,' zei hij.

Niet eenmaal veearts, naar de modder moesten zij, het was alsof hij bij voorbaat nijd gevoelde zijn afstammelingen zo hoog of hoger dan hij zelf te zien staan. Maar hij had niet afgerekend met hun inborst, met zijn eigen hardnekkigheid, die hij hun tot erfdeel had gegeven, met hun nog sterkere wil dan de zijne, die hem hier overmeesteren moest.

'Kom,' zei hij op een morgen tot Stanislas. Het was in de vakantietijd en het was de dag van het varkens slachten. 'Kom.'

Het was alsof het kind door een geheime ingeving schroom kreeg:

'Waar naartoe, vader?'

'Dat zult ge ondervinden.'

Tegenspreken was hier geen gebruik. Hij had overigens de knaap reeds bij de pols gevat, en trok hem met een ijzeren vuist op 't voorhof mee.

Vaas en een helper hadden juist een zwijn vast, de ene bij de oren de ander bij de staart. Een groot mes schoot vonken van staal in de zon.

Het dier schreeuwde vervaarlijk.

'Neen, neen,' huilde ook Stanislas in doodsbenauwen, hem door de moederlijke natuur overgeleverd en door de opvoeding ontwikkeld nog. 'Neen, neen, vader, ik wil 't niet zien, laat mij los! los!'

Hij wrong met alle kracht om zijn hand vrij te krijgen.

De vader grijnslachte met het genot van de kloekere, die van de overwinning zeker is. Hij gewaardigde zich niet te antwoorden, maar zei tegen de slager:

'Wie heeft dat nog ooit geweten, andere jongens zouden zich de benen aflopen voor zulk een schouwspel en deze gruwt ervan. Allo, lafaard, ge weet toch immers wel, dat ge zelf slager worden moet,' dit laatste tegen het kind dat een nog heftiger noodgeschrei aanhief.

Stanislas wilde 't niet zien, bepaald niet, hij verborg het aangezicht achter de vingers, en hij zag het toch door een nieuwsgierigheid geboeid: het weerstribbelend zwijn, met ruwe onmenselijkheid voortgesleurd, de keel doorstoken. Rood gutsen; een der beulen erop schrijling gaan zitten en schokken, schokken om het dampend bloed in dikke straal uit de wonde te doen vloeien. Hij zag een hand die de vangkom hield. Vervolgens, met 
woeste haast, met felle greep de borstels ${ }^{8}$ uitgetrokken; een groot vuur dat hoog oplaaide; hij hoorde de huid kraken, het haar knetteren en hij rook een reuk, een afschuwelijke reuk van verzengd vlees...!

Het was wellicht een geluk dat hij ondanks zichzelf gekeken had.

Brr! zijn gruwel was tot het toppunt geklommen. Het oproerig bloed, dat in hem was, bruiste op en, dwang en oppergezag vergetend of miskennend, in zijn verontwaardigde muiterij, schopte hij herhaaldelijk naar zijn vader.

'Nooit, hoort ge 't, nooit zal ik slager worden.'

'Doe dat nog eens en ik sla u dood,' zei Rogiest, terugdeinzend, zedelijk overwonnen.

'Als ge durft', sprak de jongen met de roekeloosheid van de onzinnige, driest op zijn vader toetredend, zich stellend vaardig' voor de ongelijke strijd.

Deze herkende zijn eigen aard in het kleine ventje, dat zo kranig hem aandorst. Zo was hij ook geweest in zijn kindsheid en zijn jeugd!

En: 'Bravo!' juichte onwillekeurig zijn gemoed, zijn bloed, terwijl zijn eigenliefde inwendig vloekte over de nederlaag.

\section{VI}

Met Elvire was zijn wedervaren al even weinig bevredigend. Eens dat zijook gedurende diezelfde vakantietijd - met een haakwerkje op de buitenbank in de schaduw zat, ergerde hem die aanblik, hij had hem al dagen lang geërgerd, nu gaf hij zijn misnoegen lucht:

'Luie vod, waarom werkt ge niet in de tuin of op't land? Er zijn geen wiedsters te krijgen, het loof-(rapen)land staat vol hondsdulle en henneslei. ${ }^{10}$

Elvire zag haar fris katoenen kleed en haar blanke, welverzorgde handjes aan. Zij waren niet gewoon aan morsige veldarbeid en er ook niet toe geschikt. Haar kleed scheen op enige afstand gans wit, van dichtbij was het met kleine rode stipjes oversproedeld.

Ga in zulke een dracht op de akker werken!

Hij had die blik en die onuitgesproken redenering opgemerkt. En zijn antwoord draalde niet:

'Doe dat uit, die jufferdracht past u niet, dadelijk hoor; neem krabber en houweel en stel u te deugen op het loofland.'

Zijn oog was boos, zijn toon duldde geen verwijl.

Elvire stond op, wikkelde haar werkje in een doek en vertrok schoorvoetend.

Zij ging zich op haar kamertje omkleden. Een kwartier later lag zij op het akkerstuk buiten het tuinhekje dan nog, waar wel geen straat, maar toch een mennegat (1) was, waar soms mensen voorbij kwamen.

Het was op het einde van augustus en zeer heet, de zon brandde op haar

(1) Aardeweg op eigen land, meest tussen twee sloten. 
rug. Zij had een zonhoed opgezet en zweetdroppelen, vermengd met tranen, liepen er onder haar wangen af. Haar knieën deden zeer van het kruipen over de grond.

Moeder, de zelf verdrukte en toch altijd anderer troosteres, was eens zijn oppergezag ontduikend - tot in het schoollokaal gegaan.

Elvire kende niet goed het welig tierend onkruid of, het hart vol wrok, rukte ze zonder veel acht te geven evenveel jonge vruchten als schadelijke planten uit.

Eerst lijdzaam toegevend, ongewillig gehoorzamend, groeide allengs de verontwaardiging inwendig. Haar bloed kookte van toorn en toen haar vader, na een paar uren, kwam zien, hoever ze gevorderd was met haar werk, zat ze met de houweel in de hand, halsstarrig te kijken naar de blanke trechters van de winde, waarvan enkele ranken enkele elzestruiken in de kant (1) overweldigden. Maar zij zag ze niet, zij zag niets in haar woede.

Rogiest bleef op enige afstand staan, haar bespiedend, zonder medegevoel voor dat jonge meisje, aan een hogere beschaving dan proletariërsstand behorend, zonder het natuurlijk medelij, dat elke voorbijganger zelfs voor een onbekende voelt, die alleen - schrikbeeld der wiedsters - op een uitgestrekt veld moet arbeiden!

Sluipend kwam hij nader, van achteren en gaf haar een bons op de rug.

Zij verschrikte, sprong recht en in haar dolheid hief zij de houweel dreigend in de hoogte.

Haar ogen schoten vuur. Hij werd bang voor haar en deinsde achteruit. Dan ineens, als ware zij zelf verschrikt geweest over de mogelijkheid van hetgeen zij had kunnen doen, wierp zij het werktuig voor zijn voeten, en vluchtte zij over de tulken (2) en de voren als een haas de tuinpoort in, achter de gelende bonen-bedden uit zijn gezicht verdwijnend.

Het was wellicht zijn bedoeling niet geweest haar als een slavin aan de keten van de veldarbeid te leggen. Wellicht had hij het enkel uit plaagzucht en uit korzeligheid gedaan; althans er was in het vervolg geen kwestie meer van ruwe bezigheden en Elvire bleef ongestraft voor haar vijandig optreden.

\section{VII}

In luiheid konden zij echter niet opgroeien - die kinderen - indien zij met de vingeren niet werken wilden, moesten zij het doen met het brein en, gemakkelijker dan zij het gehoopt had, bereikte de moeder thans haar doel. Elvire mocht naar de kostschool gaan. Aan die kostschool was een normaalschool gehecht, waar zij vervolgens haar studiën van onderwijzeres voleindigen zou.

(1) Reeks van elzestruiken.

(2) Kleiachtige aardklompen. 
Wel schimpte hij met het voornemen, wel vitte hij op de kosten van het uitzet, maar zijn verleende toestemming was het punt van belang. Deze kon hij niet meer intrekken.

Nog voordat Elvire het ouderlijk dak verliet, greep een grote gebeurtenis plaats. Stanislas, welke sedert het gebeurde met het slachten, stil, dromerig en afgetrokken scheen, riep op een morgen zijn moeder-vertrouwelinge alleen in de spreekkamer. Het schijnt alsof de aankondiging van een stap van betekenis altijd een zekere plechtigheid, en een bijzonder schouwtoneel vereist. Hij riep haar dan elders, al waren zij alleen in de keuken. En aleer hij de mond opendeed, raadde zij iets gewichtigs aan zijn gedempte, mysterieuze toon en zijn neergeslagen wimpers.

Maar dàt, neen dàt had ze niet verwacht. Hij deelde haar mee, dat hij pastoor wilde worden, en smeekte om haar voorspraak bij vader, want hij zag een geduchte kamp vooruit.

Een grote verbazing, weldra vervangen door een stormachtige blijdschap, ontstond in haar:

'Stanislas! priester, gij priester!' riep zij, de immer zo stille, heel buiten haar karakter, kletsend de handen boven haar hoofd samenslaande.

Dan kwamen de bezwaren bij haar die, onderwezen door het noodlot, de dingen in 't zwart zag:

'Och, jongen, neen, neen, dat kan niet, het is niet uit roeping, het is om aan' - zij had op haar tong te zeggen: 'de brutaliteiten van vader te ontsnappen,' maar zij hield zich bijtijds in - 'om de strengheid van vader te ontgaan,' verdraaide zij haar mening.

Nooit maakte ze inbreuk op zijn gezag bij de kinderen, nooit een woord van blaam over zijn handelwijze, hoezeer haar hart ook bloedde, als hij onverstandig of boos ze bejegende.

Stanislas verzekerde haar van neen, dat het God was, die hem wenkte, dat de gedachte aan die levenskeuze met hem was opgegroeid, en hij er reeds met de deken ${ }^{11}$ had over gesproken, zijn vocatie had betwijfeld, met zichzelf gestreden tegen de aandrang, die al machtiger en machtiger hem van de wereld wegtrok.

In helder zonnelicht zag ze de toekomst voor hem liggen als een open veld zonder hinderpalen, zonder stronkelstenen of groeven. Onafhankelijk! geen grillen te verduren, vrede en rust in zijn woning!

Zij 'kende haren zot,' zoals sommige vrouwen haar gemaal oneerbiedig bij zichzelf of achterrug noemen, zij koos een gunstig ogenblik om hem de schuchtere mededeling te doen.

Rogiest trok de wenkbrauwen op, keek haar vorsend aan met de stoute, staalgrijze ogen en zei:

'Gij hebt hem dat in de kop gestoken, gij?'

'Ik viel als uit de lucht, toen hij het mij verklaarde, neen, ik niet, vader,' zei ze, 'maar dat het mij verheugde, loochen ik niet.'

Hij wist dat ze niet loog, maar kon het over zich niet krijgen haar de 
genoegdoening te gunnen van te bekennen, dat hij geloof aan haar woorden hechtte.

'Dat zullen wij God en de molenaar laten scheiden,' (1) sprak hij bitsig.

Wanneer hij aldus haar goede trouw in twijfel trok, bruiste toorn in haar op, des te heviger, omdat hij geen uiting hebben mocht. Op haar beurt zag zij hem aan: misprijzen, haat, verachting, oproer, alles lag verenigd in de strakke diepten van haar koude blik.

Hij was niet intuïtief, hij kon daar niet de waarheid in lezen; maar hij sloeg de ogen neer, als een hond, die zijn minderheid voelt, en het oog van de mens niet - op zich gericht - verdragen kan.

Reeds meer dan eenmaal was ze zich die macht over hem bewust geweest, had hij toegegeven daaraan, heimelijk beheerst door haar grote kracht, doch enkel gebruikt, wanneer het haar kinderen gold. Wellicht vermoedde hij de onverdelgbare natuuraard in haar: de leeuwin, die in elke moeder sluimert, en wakker schiet ter verdediging, als haar kroost wordt bedreigd.

\section{VIII}

$\mathrm{Na}$ de kerstvakantie vertrok Stanislas naar het klein seminarie van Roeselare. Tot dan had Rogiest het nog uitgehouden openlijk weerstand te bieden, al was hij lang reeds met het plan verzoend, al beantwoordde het aan zijn innerlijke wens. Hij wilde zijn gezag doen gelden, vermoeilijkte alles, met haarkloverijen en spitsvondigheden, bromde over de ontzaglijke kosten, wenste nooit kinderen te hebben gehad, en deed dit luide, in hun bijzijn. Hij schold ze voor indringelingen die zijn vrede verstoorden.

'O vrij zijn!' dat was toen de smachtkreet die in 't hart van zijn vrouw ontstond en haar borst onder een zucht ophief.

'O vrij zijn, uit de klauwen geraken van die dwingeland!'

Eens - juist op de vooravond van zijn vertrek - zag Stanislas, in de schemering, van het vroege winterduister in de keuken komend, toen zijn vader langs een andere deur eruitging, dat zijn moeder, in machteloze gramschap, de vuist gebald achter hem uitstak, en een vloek of een verwensing, althans iets, dat hem - Stanislas - verschrikken deed, binnensmonds mompelde.

De aanblik trof hem diep en later, toen de beiden reeds lang van de lijst der levenden waren uitgewist, vergat hij die nooit; hij behield de twee figuren eeuwig in zijn fantasie: de grote, grove man, gewapend door de natuur met overwegende lichaamskracht, en het schrale vrouwtje, gebogen en gekrompen, ongelijk toegerust voor de huwelijksstrijd, in een verwoed gebaar, in een zondige vermaledijding wraaktroost zoekend.

Een eindeloos medelij beving zijn ziel voor zoveel opgekropt, heldhaftig

(1) In 't midden laten. 
verborgen gehouden wee. Hij naderde haar zachtjes, legde zijn arm om haar schouder, trok ze nader aan zich en murmelde: 'Moeder, goede, brave, ongelukkige moeder!' aan haar oor.

't Is niets, 't is niets', zei ze, haar wrang geheim ontdekt ziende, 'een woordje met vader. Och kind, het is stil waar het nooit waait.' Zij poogde te glimlachen.

Maar Stanislas vervolgde, in verontwaardiging ontvlamd: 'Zo zal 't niet blijven duren, moeder. Ik word een man, ik zal u verdedigen, ik zal eens zien of hij u zal blijven verpletten onder zijn voet.'

'Zwijg, jongen, zwijg, denk dat hij toch uw vader is en gij hem eerbied verschuldigd zijt.'

'Moeder,' zei hij, een toon van hartelijkheid en strelende sussing aanslaande, 'moeder, als ik priester gewijd ben, en onderpastoor genoemd word, op een stil dorp, moeder lief, dan huren wij een klein, net huis, en dan komt gij bij mij wonen; dan zullen wij gelukkig zijn moeder, nietwaar, moeder?'

Zij had tranen van aandoening in de ogen, zij glimlachte hoofdschuddend, zij scheen niet volkomen verzoend met het vooruitzicht, maar wilde hem niet tegenspreken:

'Kastelen in Spanje,' zei ze enkel met een zucht.

\section{IX}

$\mathrm{Nu}$ waren zij weer alleen als in de eerste maanden van hun huwelijk. Het had er wel een zweem van soms, wanneer Rogiest bij uitzondering wat minder slecht geluimd was. Er bleef zo menig punt van aanraking; zulke grote gezamenlijke belangen en bekommernissen stonden op het spel. Dat gaf aanleiding tot besprekingen en schikkingen, gezagvoerend, stroef soms van zijn kant, vreesachtig, steeds voor uitvallen beducht, van de hare. Zij beefde reeds des avonds, wanneer zij het gekraak van zijn sleutel in het deurslot hoorde, stond beteuterd van haar stoel op om hem, die met een weldoende, frisse lucht binnenkwam, te verwelkomen en te helpen, een stoel bij de dis te schuiven en hem te dienen als een nederige meid. Hij wilde namelijk geen bestendige dienstbode in huis. Zij deed alles meer naar zijn zin, beweerde hij en hield dat voor een compliment, achteloos of hij haar daardoor verootmoedigende lasten oplegde.

Dit was een bron van verdriet voor haar, een van de vele bronnen van ergernis, die om haar heen bestendig sproten.

Zij was aldus niet grootgebracht, en kon geen vrede vinden met zwarte ets-inkervingen op haar vingers en de palm van haar hand, tevergeefs met een pluimsteen ${ }^{12}$ geschrobd, tevergeefs met koffiegruis gewassen. Het ergerde haar de nagels niet rein te kunnen houden, ondanks de altijd gerede ganzen-koterpen. 
Dat wist hij zelfs niet, hij merkte het niet op, en indien hij het bij toeval had gedaan, zou het hem toch niet gehinderd hebben.

Wanneer hij haar eens vriendelijk aankeek, vergat zij alles, dadelijk meegesleept, veel te voorkomend, knikkend, instemmend van zodra hij de mond opende.

Verre van hem te bevredigen, prikkelde zulks zijn ongeduld, hij gevoelde instinctmatig, dat hij als een bedorven kind behandeld was, en werd weerspannig. Hij sarde haar en snauwde haar toe.

En als een weekdier kroop ze figuurlijk in haar schelp, zich wel voornemend nooit meer minzaam tegen die brombeer te zijn, verbitterd, gekrenkt, de fijne snaren van haar innig gemoedswezen ruw en smartvol aangetast.

Zij kon 't niet leren afstotend, terugwijzend en onhartelijk te worden.

Maar de haat kookte op in haar, de zucht naar vrijheid barstte toomloos los:

'Onrechtvaardige, woestaard, schelm, schurk,' verweet zij hem stilzwijgend, 'ik wenste dat ik u nooit meer zag, nooit meer aan $\mathrm{u}$ dacht, nooit meer van u hoorde spreken!'

\section{$\mathbf{X}$}

Elvire had gevraagd in een van haar brieven om in de eerstvolgende vakantie een paar vriendinnen uit de kostschool te mogen meebrengen. Hoe ongastvrij een huis ook mag wezen, de kinderen voelen toch dat het 't hunne is, en durven ernaar handelen. Het werd haar ook niet verboden en twee gezusters, dochtertjes van een geneesheer, zouden haar vergezellen.

Stanislas had van zijn kant bericht gezonden, dat de principaal $^{13}$ van het college een dag naar Vroden zou komen doorbrengen.

Wat zou de moeder zich verheugd hebben over die dubbele tijding, in het vooruitzicht de beiden genoegen te doen! Het werd haar dra terdege verbitterd. Rogiest was bij ongeluk juist gans uit zijn humeur.

Hij wierp de brief van Stanislas gekreukt op de tafel met een vloek:

'Ik heb maar mijn zondagen en hoogdagen vrij. Ik leid een slavenleven, moet ik dan nog gasten ontvangen en complimenten maken? Kunnen zij mij met rust niet laten? Wat gaat dat vreemd volk mij aan?'

'Och, vader,' suste hem zijn vrouw, 'we zijn ook jong geweest, wij hebben ook kameraden gehad.'

'Ik niet,' zei hij stuurs, met broeiend onweer in de wenkbrauwen, naar haar opziende, 'ik heb nooit anders geleefd dan voor mijn plicht, nooit vriendschap gekend.'

Dat was de waarheid, nimmer had zijn hart in harmonie met een ander hart geklopt, nimmer behoefte aan uitstorting of mededeelzaamheid gevoeld.

'De principaal komt enkel voor een dag,' zei ze. 'Elvire zal zich de meisjes aantrekken, wij zullen er niet veel last van hebben.' 
'Weet ge wat? Ik zal weggaan zolang ze hier blijven, mijn tafel elders kopen, gij kunt $\mathrm{u}$ hier met de zaken uit de slag trekken, zoals het gaat. Heel de boedel mag om zeep gaan ook, wat kan 't mij schelen!'

Hij bromde wel, hij klaagde wel, maar was er verre van af zijn bedreiging uit te voeren. Hij was laf tegenover haar, als zij wilskracht toonde.

Zij was heel opwekking, liep bedrijvig rond om alles te schikken en te regelen.

De gasten werden op een donderdag - op de hoogdag van Onze Lieve Vrouw Hemelvaart - 15 augustus verwacht. Op het laatst had Elvire geschreven, dat de vriendinnetjes 's avonds insgelijks vertrekken zouden. Dit had haar vader enigszins met het bezoek verzoend.

Hijzelf - in zijn hemdsmouwen, met een vuil keukenvoorschoot omgebonden - ging in het hoenderhok een paar kuikens uit de schreeuwende, en langs alle kanten vluchtende hoop pakken, stak ze de keel af en stond - met boos genot - ermee in de hand, terwijl hun bloed neerzijpelde en zij, een laatste maal in de doodsstrijd hevig met de vlerken sloegen. Taarten werden gebakken, groenten gereed gemaakt. Grote stukken rundvlees en kalfvlees binnengebracht. Zij had hem verzocht geen zwijnevlees te moeten opdienen, en zelfs had zij een waagstuk aangegaan: de koperen weegschalen en de hammen, die in grauwe zakken in de winkel hingen, verwijderd, met behulp van Vaas, die grinnikte in 't begrijpen van haar hoogmoed.

Rogiest had toegezien, niets gezeid. Dit had haar aangemoedigd ook de haken, voor het vers vlees bestemd, weg te nemen, een tiental bloempotten op de toch nog hinderende, maar niet verwijderbare toonbank te plaatsen, die aldus reden van bestaan scheen te krijgen. Het zilverwerk - een erfdeel van haar ouders, dat nooit gebruikt mocht worden - en het porseleinen koffieservies werden uitgehaald en afgewassen. En terwijl zij al deze toebereidselen maakte, rees het misnoegen in haar hart; zij moest dagelijks eten met een ijzeren vork, scherp van tand, en die voor haar verfijnde zintuigen een smaak aan alles gaf; met een tinnen lepel, die grauwe strepen op het bord naliet.

Een wit tafellaken werd niet geduld; het moest van ongebleekt handdoeklinnen wezen, o en zovele dingen waren er nog, die ze anders had gewild. 'Meesteres zijn, hervormen, verbeteren!' murmelde zij, en opnieuw kwam de innige wens zich opdringen: 'Here, zes jaren, laat mij zes jaren na hem genieten van het leven!'

\section{XI}

De principaal van het college was een zeer innemend man, hoog beschaafd en die zijn, door de natuur scherpe trekken, tot zachtmoedigheid te plooien wist. Hij drukte de vader van zijn geliefde leerling hartelijk de hand en stak die ook uit naar vrouw Rogiest. Met heilig ontzag, in gevleid verbazen over 
deze gunst, vatte zij die blode. Zij was niet gewend eraan, dat de deken en de onderpastoors, die bij gelegenheid te harent om de St.-Pieterspenning ${ }^{14}$ of voor een andere geldinzameling kwamen, haar als wereldlijken begroetten. De zwarte lange toga, die door de gang ruiste, dwong haar diepe eerbied af, en zij voelde nu de voldoening, dat alles in de winkel in orde was, en het oud huis er zo deftig mogelijk uitzag.

De twee juffrouwen, welke met Elvire aldra binnentraden, van bedwelmende reuken begeleid, schenen zeer pretentieus en alles uit de hoogte te beschouwen. Zij maakten een groot contrast met de beminnelijke geestelijke, en keken eens geringschattend om naar haar rieten stoel, alvorens zich, met een minachtende glimlach neer te zetten.

Stanislas had slechts blikken voor zijn aangebeden leraar en straalde zijn zaligheid in ogenglans en glimlach uit. Hij draaide en drentelde om de principaal als een hondje om zijn meester. Het was alsof deze aan vrouw Rogiest vlugheid van vernuft en welbespraaktheid inblies; nog nooit had ze zich zo onbevangen in 't bijzijn van een hooggeplaatste onbekende voorgedaan. De meisjes integendeel schenen door houding en gebaren, én terugwijzende hoogheid haar al het zo-even verworvene weer te ontnemen.

Om uit de verlegenheid te geraken, haalde zij een fles portwijn. Haar hand beefde, die de aftrekker ${ }^{15}$ - onder de ongewenste ogenhulp van al de aanwezigen - hanteerde; en met een wrang bewustzijn van verootmoediging gevoelde zij dat het midden, waarin zij zich sedert jaren bewogen had, zijn verstorende macht over haar aangeboren distinctie en aangeleerde wellevendheid had uitgeoefend.

Ach, neen, ach neen! Zij wist zich niet meer te bewegen in voorname of verwaande kring. Zelfs haar klederdracht, haar opschik kwam haar potsierlijk kaal en smakeloos voor. Zij kreeg een indruk van oude rommel, van beroest ijzer in de zon gebracht - zij zelf was die rommel en dat ijzer, van gladheid en glans beroofd.

De meisjes wilden niet drinken, de principaal stootte hoffelijk zijn glas tegen het glas van Rogiest aan; en deze vond het geraden te verklaren, - ofschoon hij volstrekt geen jeneverdrinker was - dat hij meer van een harden (1) hield dan van al die pommade-drank. Waarna hij zelftevreden lachte. Een hier volkomen misplaatste plompheid, die zijn vrouw het rood der schaamte naar het aangezicht deed stijgen, terwijl de principaal eens uit beleefdheid toestemmend knikte, en de twee nufjes een gegiechel, dat volstrekt geen bewondering insloot, lieten horen.

Stanislas voelde een vochtige warmte langs de rug. Och! wat ging vader nog al vertellen! geschiedde het uit dwaasheid of om zijn huisgenoten te vernederen?

Aan de tafel toonde Rogiest de stalen vork, waarmee hij geëist had zelfs nu te mogen eten. Hij hield die met de tanden omhoog:

(1) Glas brandewijn. 
'Dat stekt beter in 't vlees dan zilver,' zei hij.

'Een wijnkelder bezit ik niet,' vond hij gepast te berichten, 'als wij een fles of wat nodig hebben, halen wij ze naar de winkel.'

Stanislas had - van zijn drinkgeld ${ }^{16}$ gekocht - een paar flessen champagne mee.

'Ei, ei!' maakte Rogiest de opmerking, 'de wereld is net omgekeerd, wat zouden mijn ouders staan kijken, indien ze terugkwamen! En zij leefden ook gelukkig in hun stand.' Hij keek naar Stanislas en beurtelings naar zijn vrouw en dochter om het bezerend effect van zijn woorden te berekenen.

Hun zichtbare pijniging gaf hem voorzeker een zeer gewenst genot, want hij vervolgde: 'Ik moest in de kruiwagen lopen, toen ik pas negen jaren telde, ik meen aan 't zeel trekken, want vader stak hem voort.'

'Maar,' antwoordde de principaal, die met leedwezen bemerkte, dat de aanhoorders - behalve de immer spotzieke, vreemde meisjes - als op hete kolen zaten, 'gij hebt toch studiën gedaan, gij zijt immers veearts.'

'Ja,' en hij ging ik weet niet wat vernederends erbij voegen, toen Stanislas, zijn schuchterheid overwinnend, opstaande met het glas vooruit, de gezondheid van zijn leermeester voorstelde.

Dit deed het gesprek, dat zo drukkend was, tijdelijk afdwalen.

De twee nufjes schenen de spijzen alle te versmaden, voor elk gerecht dankend of enkel van iets proevend om 't overige op hun bord te laten liggen. Vreemd was 't dat een zo eenvoudig, degelijk meisje als Elvire zulke gezellinnen uitgekozen had.

$\mathrm{Na}$ 't maal werd voorgesteld naar de ruïne van 't slot van Meidale te gaan zien. Dat was een halfuurtje vandaar.

Stanislas hoopte dat vader thuis blijven zou, maar vond misrekening. Hij stond reeds in het deurgat gereed, voordat de anderen klaar waren.

En heel het gezelschap - bij uitzondering van moeder - begaf zich op weg. De processie was des morgens uitgegaan. De straat lag met verslensende bloempjes en gladde, als metalen palmblaarkens en stervend groen bestrooid, dat, wegstuivend in de zomerwind, een eigenaardige, sterke reuk van verdroging verspreidde.

De dorpsvrouwen zaten aan de deuren te kijken naar de schaarse voorbijgangers. Hier en daar stond een tafeltje, waarrond met de kaart werd gespeeld.

De nieuwsgierigheid was opgewekt. Men staakte het delen of het uitgaan. ${ }^{17}$

Aan de ommedraai van 't laatste huis van Vroden, waar de wegen in verschillende richtingen scheiden, riep Rogiest zijn zoon, die enige stappen vooruit was, terug:

'Langs daar niet! Wat is er aan een hoop verbrokkelde stenen en gebarsten muren te zien? Laten wij liever naar Diependale gaan, naar 't kasteel van mevrouw Pijpeling, dat tenminste nieuw is.'

Niemand dorst tegenspreken en men toog erheen. Het was veel verder dan de ruïne van Meidale, door lage wegen met waterpoelen bezaaid, langs 
de zogenaamde Zompelingen, en voorbij de kapel van het Neerland.

Daar wilden de meisjes binnen en deden er kaarsjes ontsteken door de zwartbekapte wachtster. Dan volgde er onder het half duister gewelf een algemeen stilzwijgend gebed, door het knetteren van de vlammetjes in geheimnisvolle vroomheid begeleid.

Het kasteel bood niets merkwaardigs aan: het was een modern gebouw in rode baksteen; maar het park was overheerlijk, met zijn dikstammige, breedgekruinde eiken en zwart-groene reuzenolmen. Om erin toegelaten te worden, hoefde men zich tot de tuinman te wenden, die, op hoop van een goede fooi, de wandelaren door alle dreven en slingerpaden leidde, en ten slotte, met de traagheid aan zijn beroep eigen, de juffrouwen elk een tuil van dahlia's en flox afsneed, waarvan de regelmatige fluwelen pijpjes en de rijke kleursterren, ondanks de verstikkende floxreuk, geestdrift wekten.

Aan dit alles werd tijd besteed, te veel, en toen het gezelschap eerst langzaam-achteloos, en eindelijk, op het herhaald aandringen van Rogiest, met versnelde schreden aan het station van Vroden kwam, floot en vertrok juist de bewuste trein.

Het was de laatste, die naar 't oord van hun bestemming voerde.

Algemene verslagenheid, bewegingen van vooruit-willen, ondoordachtinstinctmatig, doelloos. Uitvallen van Rogiest tegen zijn zoon en dochter, dat het hun schuld was...

Een rijtuig nemen? Dat was de eerste gedachte, die bij de geestelijke opkwam.

Het doel was uren ver, het werd reeds laat, overigens met het festival van Zompelgem waren alle beschikbare voertuigen weg.

Geen ander middel dan te Vroden blijven overnachten.

De twee nufjes vonden 't grappig en lachten als om iets zeer vermakelijks. De principaal zette een bedenkelijk aangezicht.

Maar wie het meest in verlegenheid verkeerde, was vrouw Rogiest. Grote God, waar zou ze al die mensen te slapen leggen?!...

\section{XII}

Stanislas stelde voor zijn bed af te staan, - maar de kamer was niet mooi genoeg om er een voorname personage in te leggen. Het logeerbed moest dienen voor de juffrouwen, moeder en dochter deden een uiterste poging bij vader, dat hij zijn slaapvertrek opgeven zou. Met een geduchte vloek zei hij, dat het hem om 't even was.

Hoe zulk een toestemming misnoegen en verwijten wekt, weet hij alleen die ze verkrijgt; wel tienmaal betreurde zijn vrouw het bitter die gevraagd te hebben.

En terwijl zij alles in gereedheid bracht, ondervond zij alweer hoeveel er ontbrak aan welstand niet alleen, maar aan 't nodige in haar huis; enkel 
grauwe handdoeken, geen behoorlijke spiegel of wasstand, en, wat haar het meest, en gedurende heel de tijd van haar huwelijksleven geërgerd had: waren de opgedrongen blauw-en-witgeruite overtrekken voor de kussens. Haar huis was misschien het enige van al de burgershuizen in het dorp, waar men geen witte slopen gebruikte.

$\mathrm{O}$ vrij zijn, van die dwingeland afgeraken, was nogmaals de smartkreet van haar hart.

Deze kleinigheden waren de vormen, welke het algemeen wereldwee, waaraan geen sterveling ontsnapt, bij haar aannam. Niet alleen dingen als deze, aan welke Rogiest inderdaad schuld had, maar alle andere waar elkeen noodzakelijkerwijze door lijden moet, werden op hem geschoven. Van hem los, zou alles in rozekleurige toekomst, in eeuwigdurende zonneschijn liggen...!

Het ergste stond haar nog te wachten: 's morgens voor de dageraad kriekte, was de veearts opgestaan. Zij kon maar niet begrijpen, wat hij zo vroeg te doen had.

Voorzeker was het harde strobed van de bij toeval voor één nacht afwezige Vaas, dat hij voor lief had moeten nemen, schuld eraan. Zij ook kwam spoedig beneden.

Tot haar niet geringe ontzetting, zag ze haar man in witlinnen schort in de winkel bezig met de hespen in hun vuile, vette linnen zakken weer aan de spijkers op de muur te hangen. De haken voor het verse vlees bengelden reeds aan de heraangeknoopte koordetjes.

'Vader, wat doet ge toch!' was haar alarmkreet. 'Wacht om godswil tot ze weg zijn. Ze vertrekken immers met de trein van kwart over negen.'

Hij had een grijnslach van leedvermaak:

'Ik wil mij niet grootser tonen dan ik ben,' verklaarde hij, zijn arbeid tijdelijk stakend, naar haar omgewend.

Helaas! een noodgehuil ging op voor de varkensstal, en, buitenlopend, radeloos, bemerkte zij het aangezicht, van de zozeer geëerbiedigde gast, die, zeker verschrikt opgesprongen, uit de slaap gewekt, aan het kamervenster kijkend verscheen.

Zij had Rogiest 's avonds tevoren bezworen het slachten te verschuiven tot later op de dag. Het was zelfs iets ongewoons, dat het zo vroeg geschiedde, en hij moest bevelen dienaangaande aan Vaas gegeven hebben.

Het geval nam in de overdrijving van haar gekwetst gevoel de evenredigheden van een ramp. Het kwam haar voor, dat haar kinderen door het aan 't licht brengen van alles, wat zij uit fatsoenlijkheid verheimelijken wilde, onteerd moesten zijn.

'Ei, ei!' zei een van de meisjes benedenkomend, tactloos en verootmoedigend tot Elvire: 'Een slachterswinkel!'

'Wat was ik verschrikt,' sprak de andere, 'toen ik dat gillen hoorde, en nog meer toen de weerschijn van de vlammenlaai in onze kamer sloeg. Ik meende dat het huis afbrandde. Br! wat een nare zenglucht.' 
Elvire was een moedig kind, zonder aanspraak op voorname handelwijze of hoger stand-voorstelling; maar Stanislas leed er oneindig onder, en had al zijn christelijke verduldigheid in te roepen om zich voor te houden, dat het een beproeving was, hem opgelegd door de Almachtige, een straf voor zijn hovaardigheid.

Voordat de gasten vertrokken, vroeg de principaal, in bescheiden afzondering, stil aan Rogiest, waar de meid was. Hij hield een tussen de vingers, nauw bespeurbaar uitblinkende zilverfooi in de hand.

'Er is hier geen meid,' antwoordde Rogiest heel luid, dat allen het hoorden, 'degene die ons gisteren diende, was een werkvrouw. Moeder is hier de meid,' voleindigde hij zijn mededeling.

De twee nufjes lachten weer. Zij hadden hier nog niets anders gedaan, en namen thans een koel, terugdringend afscheid van de huisvrouw. De geestelijke bleef even innemend vriendelijk als bij zijn binnentreden.

Wat kon 't haar troosten?

Wat kon 't haar schelen, dat die twee haar verachting toonden? Zij ook verachtte ze om hun wereldse denkbeelden.

Maar dat de man, wiens onderdanige slavin zij heel haar leven geweest was, haar met opzet kwellen, en in de grond boren wilde, dit deed haar lang gesmoorde toorn uitbarsten: ineens trad zij, de vreesachtige, bang-onderdrukte, met gesloten vuist op hem toe, klein en schraal van figuur, maar te duchten door de zedelijke kracht, die uit haar sprak, roekeloos, niets meer ontziende, voor niets meer beschroomd, toomloos als een krankzinnige:

'Schelm!' kreet ze, 'booswicht! moordenaar van mijn geluk, ik wenste dat gij voor mijn voeten doodvielt!'

Daar was 't eruit het grote woord, een openbaring voor haarzelf van de godvergeten wens: hij dood, het middel - 't enige om weer vrij te zijn...!

\section{XIII}

Jaren verliepen.

Stanislas was onderpastoor te Mullem en Elvire was onderwijzeres benoemd te Ploegvelde. Zelfs op eenmaal bestuurster van de meisjesschool. Het was ten tijde van de schoolstrijd, ${ }^{18}$ toen het liberaal bestuur, aan het bewind, overal, waar 't enigszins mogelijk was, scholen stichtte - in mededinging van de kloosterscholen - 't zij dat er leerlingen te verwachten waren of niet.

Een nieuwe oorsprong van verdriet voor vrouw Rogiest. In haar kinderen - ofschoon ze haar liefhadden boven alles - vond zij het onbuigzaam karakter van de vader weer. Elvire wilde niet van haar betrekking afstand doen, en Stanislas wilde haar niet meer of slechts gedwongen zien.

De ene kwam nog enkel naar huis als de ander er niet was.

Rogiest stierf na een korte ziekte. 
Zijn vrouw onderging een vreselijke ontroering. Het was een onverwachte slag en nooit zou ze gedroomd hebben, dat deze haar zo te pletter zou slaan.

Zij gaf zich over aan een grote tranenbui en kon noch eten noch drinken. Haar lippen spanden, koortsig droog, haar handen gloeiden, zij had het hoofd verloren, en nauwelijks tegenwoordigheid van geest genoeg om 't nodige linnen voor het afleggen uit te halen.

Dit duurde slechts één dag. Toen kwam nog wel niet de zon aan haar levenszwerk te voorschijn, maar de storm was voorbij, het werd reeds heldergrijs aan de horizont.

Zij had geweigerd hem dood te zien. Zij was van het sterfbed weggeijld, toen bij de laatste adem uitblies, en het akelige gegrol van de doodsstrijd niet meer door de woning bromde. Die rochel vervolgde haar overal, zij waande hem nog voortdurend te horen. Neen, zij wilde Rogiest niet meer zien, weerhouden door een onverwinbare tegenzin.

De aflegster had tevergeefs aangedrongen, dat zij een gebed bij het lijk van haar man doen, en hem een kruisken (1) geven zou.

'Neen,' zei ze, altijd onwrikbaar, 'neen.'

En echter, terwijl de bewaakster de tweede dag een boodschap was gaan doen en Elvire en Stanislas, tijdelijk verzoend of in wapenschorsing, adressen van doodsbrieven schreven, kwam er plots een omwenteling in haar. Traag ging ze tot aan de op een kier staande kamerdeur, draalde een wijle en stiet ze zacht open, onweerstaanbaar door een geheime impulsie aangedreven.

Zij naderde het ledikant, met de onduidelijke mensengestalte onder 't linnen. Zij trok het weg. Daar lag hij met het hoofd achterover, de neusgaten zwart, daar lag hij: geel, koud en stijf, in die aangrijpende rust, welke alleen de dingen bezitten, die wij steeds in beweging hebben gezien, en vooral een dode tot het hachelijkste schouwspel maakt.

Zijn dunne lippen waren op elkaar geknepen, als gereed om te bijten, met een nijdige uitdrukking.

Strak staarde zij hem aan, bestormd door allerlei gewaarwordingen, onontwarrenbaar doch bitter, als in een verdoving van gedachten.

Zij hief de hand reeds op, met het palmtakje tussen de vingertoppen, voorafgaandelijk in 't gewijd water gedoopt, om hem godvruchtig te besproeien, en een afscheidskruis op het voorhoofd te geven, doch zij hield zich in, wilde of kon hem niet beroeren en wierp het takje weg: 'Daar!' zei ze en dan op doffe toon: 'ik vergeef $u$ al het kwaad, dat gij mij gedaan hebt. Amen!' eindigde ze somber.

(1) Het is ter plaats gebruikelijk, dat men met de duim op het voorhoofd der doden een kruis als afscheidsteken maakt. 


\section{XIV}

En nu begon dat leven van onafhankelijkheid en blijheid, waarnaar zij zo smachtend had gehaakt. In de nalatenschap van Rogiest werd een testament gevonden, bij hetwelk hij aan zijn echtgenote alles vermaakte wat de wet hem toeliet. Was het een blijk van niet vermoede liefde en vertrouwen? $\mathrm{Zij}$ geloofde het. Was het een bewijs van vaderlijke haat, en uit geest van tegenstrijdigheid ontstaan? - Ja, veel meer aldus - deze was de overtuiging van zijn kinderen. Hun eigen onenigheid duurde voort, daar er een blijvende oorzaak toe bestond - maar in hun liefde voor de moeder gevoelden zij in volkomen harmonie.

Rogiest, welke altijd zo geheimzinnig zijn geldelijke toestand verzwegen had, bezat veel meer dan iemand zou vermoed hebben. Niet alleen effecten, maar hele rolletjes goudstukken werden gevonden. En verre van dankbaarheid bij de nageblevenen te wekken, verhoogde het hun spijt.

Hoeveel ontberingen vertegenwoordigden deze geldstukken! Hoeveel welstand ware erdoor te verkrijgen geweest!

Wat voor een bron van overeenkomst was door deze niet in haar loop gestremd geworden!

Vrouw Rogiest verdeelde al het roerende goed in drie delen, en, gaf de kinderen elk een part, er een voor haar benevens het mobilair ${ }^{19}$ behoudend. Geen van hen vroeg zich af, of het gegeven en gekregen deel de wettelijkheid overschreed.

'En nu, moeder', zei Stanislas, 'nu sluit ge de winkel en komt ge te Muilem bij mij inwonen.'

'Neen,' jongen, zo spoedig kan ik de boedel niet uit de handen werpen.'

'Moeder, liever bij mij', sprak Elvire, 'ik zal zeker te Diependale benoemd worden, o moeder, en dan gaan wij samen in het oude huis wonen, waar wij als kinderen speelden; het huisje dat u zo bekoort, waar ge zo vaak van spraakt.'

Maar zij schudde het hoofd, dezelfde beweeggronden aanvoerend.

'Nu zult ge zeker dit lelijk kot afslaan en het opbouwen volgens uw wens, ge hebt hem toch zolang gekoesterd,' zei Stanislas, wel gevoelend haar onuitgedrukte weerstandskracht om elders in te wonen.

Dit was de eerste maal na de vereffening dat hij naar Vroden kwam.

'Wat denkt gij? Vaders voeten zijn nog niet koud,' antwoordde ze, zacht terechtwijzend.

'Ik zal blij zijn als dat droog vlees met die sterke reuk van beroking hier weg is,' zei Elvire, telkens zij moeder bezocht en door de winkel ging. 'Wanneer koopt ge nieuwe meubelen, wanneer wordt alles in orde gebracht? Ik zal u helpen kiezen,' stelde zij voor.

Vrouw Rogiest zuchtte eens.

Nu had zij al de last der zaken op zich en nam moedig de teugels van de handel aan. 
Zij zelf ging van hoeve tot hoeve de zwijnen inkopen en wist, door de ervaring, hun gewicht te schatten op weinig kilogrammen na; zelfs dan, als ze in een stal stonden, die van achteren hoger lag dan naar voren, wat ze zwaarder schijnen deed.

Zij misprees de levende waar, en dong af op de prijs als een echte marktkramer doet, heengaande, terugkerend, om 't geweigerde eindelijk aan te nemen.

Het kwetste Stanislas in zijn gevoel van fatsoenlijkheid, als zij aldus naar Muilem kwam: 'Moeder, als 't u belieft, niet hier,' smeekte hij.

Zij hield geen meid, deed haar werk mechanisch zelf als ten tijde van Rogiest, toen het haar zo ergerlijk scheen zwarte onuitwisbare gravurestrepen $^{20}$ op de handen te dragen.

'Moeder, het is gevaarlijk zo gans alleen te leven,' zeiden haar kinderen, 'indien er u des nachts iets overkwam!' Vaas was lang overleden en door een slager vervangen, die getrouwd was en thuis sliep.

'Ik ben gezond,' gaf ze voor, 'liefst alleen. Overigens vrouw Pauwels komt dagelijks. Ik zou niet zo verlaten zijn, als ge denkt, indien er iets voorviel.'

Haar gedruktheid ging niet over. Was haar gemoed misschien als een graszode, waar te lang een steen heeft opgelegen en die, bevrijd van het gewicht, niet meer recht komen kan?

Menigmaal had ze afkeurend en hoofdschuddend geglimlacht, toen Rogiest, telkens er iemand was, het horloge ging optrekken, wanneer het gewicht nog enkel halfwege afgelopen was. Nu betrapte zij zich, dat ze hetzelfde deed, als Stanislas of Elvire binnenkwam.

'Moeder, zijt ge gelukkig?' vroegen zij haar soms, hoog twijfelend.

'Volkomen,' antwoordde zij lusteloos.

Zij had noch Brussel noch Oostende gezien, altijd het verlangen er eens te gaan uitgesproken.

'Willen wij nu? willen wij zondag gaan?' stelde Elvire voor.

'In de vakantie,' antwoordde zij.

Maar als de vakantie daar was, wilde zij weer niet.

'Met moeder is niets aan te vangen,' klaagden haar kinderen.

$\mathrm{Zij}$ zat als versuft voor zich te kijken, als ze alleen was.

'Vader is vandaag zes jaren dood,' zei ze eens aan Stanislas. Het was de eerste maal, dat ze van hem sprak, sinds lange, lange tijd.

'Zes jaren,' herhaalde haar zoon en, rondkijkend in het oud, naakt, ongezellig vertrek, voegde hij erbij, 'en nog niets is hier veranderd.'

'Neen,' antwoordde zij eenvoudig.

Wat later werd ze zelf ziek, moest te bed blijven en kreeg een oppasster.

Stanislas bezocht haar alle zondagen, na de vespers. Eens werd hij door een bijzondere bode vroeger op de dag uitgenodigd.

Bevend begreep hij de toestand en ijlde hij naar Vroden.

Elvire zat aan de sponde met beschreid gelaat, en door een beweging van de wimpers wees ze hem moeder aan. 
Deze grabbelde om zich heen, met de doodsverf op het aangezicht. Haar hoofd rustte op een kussen met een eertijds zo verafschuwd blauw-en-witgeruite sloop, en een tinnen lepel lag naast een medicijnflesje op het nachttafeltje. Zij prevelde iets onverstaanbaars.

Ineens opende zij de brekende ogen, en keek in alle richtingen als zocht zij iets of iemand rondom zich:

'Ha!' sprak zij, Stanislas herkennend. 'Ha!' en terwijl hij diep ontroerd naderkwam, hernam zij als voor zichzelf prevelend: 'Zes jaren heb ik gevraagd aan God, zes jaren vrijheid, en hij heeft er mij zeven gegeven! zeven... zeven...!' herhaalde zij trager en immer stiller en... ademde niet meer.

'Arme moeder, gij hebt er niet van genoten!' snikte de zoon, met zijn vinger haar oogleden neerhoudend, er het licht uitsluitend. 


\section{Plaatje mulderman}

'Een kindermoordenaarster?

Was ze dat?

'Ja.'

Zij heette eigenlijk Charlotte, bij verkorting Lotje; maar zij, die met spot of geringschatting van haar spraken, zeiden Lotje en zelfs verachtend Plate. Degenen, die haar liefhadden of haar levenswijs vergoelijkten, gebruikten het woord Plaatje.

Die naam had ik - als heel jong meisje - wel gehoord: Sieska, de meid, en Naart, de tuinman, hadden het dikwijls over haar, vooral, als de werkvrouw van hun gezelschap deel uitmaakte.

'Weet gij, wat Plaatje nu gedaan heeft?'

'Neen?' beiden, met nieuwsgierig oog.

'Het - in plaats van zij - heeft tot drie uur van de nacht in de "Steenput" gezeten.'

'Wel, wel, en ge kunt denken met welke schavuiten!'

'Die hem zijn centen afdoen en er de zot mee houden.'

'Het is toch spijtig van alzo een meisje,' zeiden ze toen.

'Och ja, het braafste hart van de wereld.'

'Het is te goed, het kan tegen 't refuseren niet.' 'Jammer, jammer!'

En Naart, onze oude Naart, die de ontroering licht beving en wiens stem vaak verkropte, nam het woord: 'Zulke brave meiskens bestaan er niet meer; ge zoudt ze bij klare dag mee een lantaarn moeten gaan zoeken. Mijn Trezeken werkt bij de Muldermans; maar 't respect, dat Plaatje voor de werkmensen heeft, daar hebt ge geen gedacht van: als zijn onkels 't niet zien, snijdt het hun schelle vlees dubbel groot. Het zou 't al weggeven. Ik ben zeker, bij manier van spreken, moest er 'nen arme om een broek komen, dat het zijn onkels laatste broek geven zou.'

'Jamaar, jamaar,' zei Sieska daarop, van onderen op, verwonderd, uit haar kleine oogjes met de verlamde schelen kijkend, 'wat zouden die oude dutsen dan zelf aandoen? Ge kunt zo goed zijn, dat ge niet meer deugt.'

Daarover was dit drietal het eens.

De werkvrouw vertelde, dat Plaatje een 'morsbrood' was:

'Als het de stove gaat aansteken, moet ge niet peinzen, dat het één fosfoorken gebruikt; maar weet gij hoevele?

'Neen,' dat wisten ze niet.

'Vijf en zes tegelijk; zie, daarvoor zijn Plaatjes nonkels zo kwaad.'

'Ze zijn in hun recht,' meende Naart wijsgerig, 'want van dat "moschen"' heeft niemand voordeel.' 
Aldus leerde ik Plaatje Mulderman kennen, voordat ik ze ooit had gezien, met de belangstelling, die men soms voelt voor dingen of personen, waarover men veel hoort.

Zij was het nichtje van de twee oude jonkmans. ${ }^{2}$ Deze zaten er goed in, het waren paardenboeren, die op hun eigendom met uitpacht, ${ }^{3}$ nochtans, woonden, wel een half uur ver van het dorp op de wijk Veldeken. Plaatje zou hun bevoordeelde erfgename wezen; maar zij leefde onder het bestendig dreigement 'bastaard gemaakt te worden' (1) en zelfs op straat gezet, indien ze geen betere weg opging. Het meisje had geen ouders meer en was bij die verwanten opgevoed.

In de grond hadden ze haar heel lief, werden door haar vertroeteld, maar konden geen vrede hebben met haar buitensporigheden.

Eens kwam Naart op een maandag in de keuken vertellen, dat Plaatje daags tevoren, na de vespers, uit het koren was gejaagd met ik weet niet welke boerenzoon. Dat was een schandaal van belang. Elk lachte erom, zei hij; en de twee, Sieska en de werkvrouw, aan wie hij 't meedeelde, hadden erg pret.

Een paar dagen later, bracht hij een ongedrukt liedje mee, dat op het geval was gedicht. De meid, Sieska, was ongeleerd, Naart evenzo; maar de werkvrouw kende, wat zij 'haar geprent' noemde, en zou ook wel uit het geschrift geraken.

Haperend las ze 't voor; ik heb enkel het begin ervan onthouden:

Mijn lieve Plaat,

Als gij dit jaar in 't koren gaat,

Houd u dan goed,

Zie, dat gij niet vervalt in boet.

'Wel, wel!' zei de werkvrouw 'en dat er zoveel herbergen zijn, waar de vrijers samen kunnen komen!'

'Ja', antwoordde Naart, ze aankijkend met zijn kleine, scherpe, blauwgrijze oogjes, op een toon van blaam: 'ge geeft ook zate (2) gij, ik weet het wel.'

'Een mens moet toch ergens geld mee verdienen,' was het antwoord.

$\mathrm{Zij}$ wisten niet, of gaven er geen acht op, dat de tussendeur openstond en wij alles zagen en hoorden.

Ik stelde mij Plaatje Mulderman voor: lenig en slank, met grote zwarte ogen en zwart haar, een ietwat bruinachtige kleur en blanke tanden. Ik had wel horen zeggen, dat ze lelijk was; maar wist ook, dat een landbouwer alle meisjes lelijk vindt, die niet sterk blozen en niet dik zijn.

Ernaar vragen, deed ik niet.

En onverwacht bood zich een gelegenheid aan, waarop ik het veelbesproken Plaatje zien zou.

(1) Onterfd.

(2) De vrijers herbergen. 
In talrijk gezelschap trokken wij - mijn zusters en ik - eens naar het op een groot uur afstand van ons dorp gelegen Hansbeke. Onze weg leidde langs de zogenaamde Steenputten, poelen, waar 't vlas in werd geroot. En juist was een hele bende werkvolk er aan de arbeid: de groene stengels werden in het water geworpen met hele bundels, en plaggen ${ }^{4}$ aarde erop gegooid. Modder lag overal op de oever verspreid.

Een meisje stond tot aan de knieën in 't nat en 'stelde zich bij' naast het mansvolk. Zij was nog meer dan de anderen bemorst en beslijkt.

Een helper ging rond met de jeneverfles, schonk in, en om de beurt dronken allen uit hetzelfde glaasje.

Zo ook het meisje. Zij goot de inhoud in haar keel, als een kolendrager doet.

Het was een heel hete julidag; maar waar zij stonden, was er schaduw. De populieren klapperden boven hun hoofd, lichte koeling aanbrengend.

Iemand van ons gezelschap zei aan mijn oor:

'Kijk, die daar, die in 't water staat, is Plaatje Mulderman.'

Ik zag haar heel benieuwd aan en schrok toen letterlijk: bijna aan een doodshoofd was haar gezicht gelijk: met ronde, holle ogen, een heel bleke kleur, een neusje met de vleugels omhoog en een grote, grote tandenmond. Het gelaat scheen $\mathrm{u}$ aan te grijnzen.

Was dat het Plaatje Mulderman, berucht voor haar talrijke liefdesavonturen en haar vele vrijers!...

Toen wij allen in de vooravond, bij langgerekte dagklaarte, over 't warme zandpad, tussen de hitteuitwalmende korens naar de grote weg toegingen, hoorden wij eerst luid geroep en gejuich en zagen weldra langs die weg de slijters aankomen. Ginder voorop reed de wagen met de ippens (1), het nodig gereedschap voor 't afrepen, en een drietal bedaagde vrouwen erop.

Het jong volk zwenkte te voet, arm aan arm, in een rij, die heel de brede baan afsloot, zingend en dansend aan.

Wij bleven staan, ongezien of onopgemerkt, om de woestheid aan te staren.

Allen waren onzeggelijk vuil, de mannen met de $\mathrm{klak}^{5}$ scheef op het hoofd, de vrouwen met het haar in blessen slingerend op de schouder of de rug; barvoets $^{6}$ in hun klompen; de broekspijpen en de rokken plakkend op het lichaam van het daaruit zijpelend nat. De aangezichten schenen erg verhit.

Eensklaps bleven allen stokstil staan, als op een halt-bevel, en schaarden zich toen weldra in kring rondom een man, die luidkeels riep, met de armen zwaaiend: 'Zijn we vandage vroeg opgestaan?'

'Jaam (ja wij)!' schreeuwden allen.

'Hebben we gewerkt als beesten?'

'Jaam!' ging het weer.

'Hebben we nen braven koopman?'

'Jaam.'

'Heeft hij ons veel jenever gegeven?'

(1) De zaadkorrels van 't vlas. 
'Ja hij!' het ging al luider en luider.

'Zijn wij allemaal zat?'?

'Jaam!' met geestdrift uitgeschreeuwd.

'Zullen we van den avond slijtpap eten, dat onze buik met een tuite staat?' 'Jaam!' was het antwoord en verder trok de groep...

Men weet dat slijtpap een gerecht is samengesteld uit stroop, melk en mastellen (1), en dat de slijters daarop vergast worden bij de boer, wiens vlasgaard die dag uitgetrokken is.

Het was één, misschien wel twee jaren later, ook in hoogzomer, dat Sieska op een morgen ongeroepen in de woonkamer kwam geijld, met een ontzet gelaat vol gewichtigheid:

'Plate Mulderman heeft haar kind vermoord. De heren van 't parket zijn op de hofstee. Naart is ze van dezen ochtend tegengekomen op de korenwegel. Hun rijtuig wachtte onder de bomen aan de hoek van de grote baan.' De woorden stropten schier in haar mond, zo haastig bracht ze 't uit.

'Plate Mulderman? ha ja, dat meisje van Veldeken, die bij haar onkels woonde en geen goede reputatie had, is 't niet zo?'

Wij hadden in lang niet meer van haar horen gewagen, ook niet meer aan haar gedacht.

'Ja, ja,' zei Sieska, 'dezelfde. Het was allang geweten, dat er iets tot stand komen moest; maar ineens was er geen kwestie meer van. De geburen hielden een oog in 't zeil. Wie 't aangeklaagd heeft aan de wet, dat is niet uitgelekt. Maar ze zal er lelijk tegenvliegen, wordt er gezeid en ze verdient niet beter, die wilde blare, ${ }^{8}$ dat schandaal!'..

Sieska, de brave Sieska, de goedhartigheid zelve, was erg verontwaardigd en gekwetst in haar bewustzijn van deugdzame levenswandel, zij, de onbesproken oude meid.

'Sieska, Sieska, oordeel niet zo streng, ge weet nog niet eens, of er iets van waar is.'

'Waar,' antwoordde zij, een van haar verlamde oogschelen half, onder een voorhoofdrimpeling, opheffend, 'waar? Het is genoeg bekend, dat het al de derde keer is, dat er wat tewege ${ }^{9}$ was, waarvan er opeens noch pluim noch staart meer uitkwam.'

'Zou zoiets inderdaad wel aldus wezen?'

Akelige levensdrama's door wangedrag veroorzaakt spookten ons voor de geest.

In de vroege namiddag ontstond er een groot gejoel in de verte, langs de dorpsstraat; alle deuren gingen open, buurmannen hadden hun werkhuis verlaten, sommigen nog met een stuk gereedschap in de hand; buurvrouwen schoolden samen, met half verschrikt, half verblijd nieuwsgierig kijkende aangezichten, een kind op de arm, een of twee aan de rok, grotere kri-

(1) Een soort van koeken. 
oelend om hen heen. En allen wezen met de vingers in één richting vooruit en deelden, samen babbelend, elkaar iets mee.

En zonder nadenken, in een onberekende impulsie, gingen wij ook de deur openen en bleven op de drempel staan.

Straatjongens en straatmeisjes in menigte - waar vandaan kwamen ze toch? - stoven aan. Waarschijnlijk was het nog te vroeg voor het schooluur.

Zij juichten en schreeuwden en maakten guitige sprongen langs beide kanten van de straat en verder ook, teruggedreven door de zweep van twee gendarmen, ${ }^{10}$ met hun hoge haren kolbaks ${ }^{11}$ op, die, wijd van elkander, te paard naderden met klinkend-regelmatige hoefslagen.

En in hun midden, enige stappen tenachter, kwam Plaatje Mulderman, met een touw rondom haar lijf, een lang touw, waarvan de gendarmen ieder een eind vasthielden.

Een onvergetelijk schouwspel van menselijke ellende en zogenaamd wettelijke gerechtigheid. Een aanblik van wreedheid zonder weerga.

De paarden gingen niet vlug, weliswaar, doch hun pas kon de gevangene toch niet bijhouden. Haar platte gestalte helde achterover op het knellend touw; zij hijgde van pijn en inspanning, en kon blijkbaar niet verder; haar doodshoofdgelaat was verwrongen; haar grote, ronde ogen puilden uit in angst, en met de twee vrije handen steunde zij op de koordestrengen voor haar, nu en dan met een beweging als om ze af te trekken.

Het was stikkend heet, als broeide er onweer in de lucht. Gent was op drie en een half uur afstand van haar huis. Daar moest zij heen. Zij uitte geen enkele klacht.

En telkens als zij - onmachtig om voort te gaan - strompelde of een oogwenk bleef staan, trok een van de gendarmen met een tuchtgebiedende ruk - omkijkend - aan het touw, zodat Plaatje schier voorover stortte. En telkens ging er een gejoel en getier op van triomf, als het ware, uit de om haar heen vijandig-verblijde, onmeedogende jongensbende.

Wij vluchtten letterlijk binnen en wierpen de voordeur toe.

Waarom waren wij toch gaan kijken! Waarom moesten wij getuigen van iets zo gruwelijks zijn...

Sieska - nadat heel de bende uit het gezicht verdwenen was zeker, kwam af met het op straat gehoord verhaal:

De heren van 't parket waren afgekomen ten gevolge van een onondergetekende brief. De onkels hadden tot dusverre niets vermoed. 'Ge kunt peinzen, hoe zij uit de lucht vielen,' zei Sieska. Huiszoeking werd gedaan, bewijzen gevonden. Plaatje loochende nog; maar werd overtuigd door de wetenschap. Er was een kind geweest.

Waar was dat kind?

Heel de woning werd het onderst boven gekeerd; schuren en stallen doorzocht; de mestput uitgeschept; de kolenhoop uiteengerafeld... en niets was er te vinden.

Geen spoor van het kind! 
Totdat de veldwachter, die slimme vos, hij was er ook bij, merkte, dat er onder de dorenhaag verse aarde lag.

'Krabbeling van de hennen,' zei een van de onkels, 'ze doen 't altijd.'

En daar, enige vamen ${ }^{12}$ diep, werd het lijkje uitgehaald, gerimpeld als een appelken, dat te vroeg van de boom is afgetrokken. Het was heel naakt, blauwachtig reeds, in begin van ontbinding. Het had een rood strikje aan de hals, waarmee het was verworgd ${ }^{13}$ geworden... Het zat al schier drie weken onder de grond...

'Och, zwijg, Sieska, zwijg, wij weten reeds genoeg.'

En, teleurgesteld over de weinige belangstelling, die haar treffend verhaal scheen op te wekken, trok Sieska beteuterd heen.

Wij hadden haar weggezonden, haar niet laten uitspreken.

Wij wilden het hartbezerend visioen verre van ons verbannen; maar wij konden niet, het drong zich aan ons op.

En aldus is het mensenhart: wij waren het nu, die zelf later aan Sieska vroegen, of zij niets meer van dat meisje had gehoord en of ze in de stad was geraakt, zo zwak en jammerlijk uitgeput, als ze scheen.

Ik weet nog, dat we in de tuin zaten, dat het reeds schemeravond werd; dat het nog zeer heet was en dat 'de zoelte speelde', zoals de boeren het heten: bleke weerlichten, die, te ver voor 't laten horen van donderknal, bestendig aan de horizon opflikkeren. Ik weet, dat een bedwelmende heliotroop- en clematisgeur in de broeiende atmosfeer hing en dat Sieska met groenten uit de moestuin kwam. Ik voel nog, bij 't heropwekken van dit alles, het onbehagelijke van die verdonkerende onweerslucht, en de beroering van 't gemoed door 't akelig geziene van die dag.

Jawel Sieska wist bescheid te geven. Ze bleef staan, scheefgebogen met de arm uitgestrekt over de vastgehouden groentenmand: Jawel, het drietal was langs de binnenwegen naar Gent gegaan. De straatbende was tot aan het IJzeren Eiksken - een dichtgelegen wijk - meegelopen en daar voorgoed door de gendarmen met de zweep uiteengedreven en teruggejaagd.

Aan de Dorre Plas - wat verder - was Plaatje in zwijm gevallen; met water besproeid - en bijgekomen - moest ze weer mee, altijd aan het touw voortgetrokken.

Op Vier-Lindekens-Kouter - zo vlak! - brandde de zon op de korens, die de luchtverplaatsing belemmerden en 'als Christus onder 't kruis,' zei Sieska, ditmaal met verontwaardigd medelij in de toon, was het arm schaap nogmaals 'kwalijk' geworden. Ten laatste hadden haar geleiders ergens op een hofstee een karreken moeten gaan halen en 'geheel van haarzelve nog', was ze aan de gevangenis afgestort.

Arm Plaatje!

'Het is toch iemands kind, het is toch een menselijk schepsel,' besloot Sieska heel vertederd, ons eigen gevoel in woorden van haar keuze samenvattend.

Plaatje kwam te Gent voor het gerecht. 
Zij werd verdedigd door een jong advocaat, herkomstig van haar streek, die later grote naam heeft gemaakt.

Ik geloof, dat het de eerste maal was, dat hij pleitte voor het assisenhof. ${ }^{14}$ Hij pleitte in het Vlaams, wat destijds iets nieuws was. Degenen, die hem gehoord hadden, vertelden met welk vuur hij het deed; hoe indringend zijn toon van overtuiging was en welke diepe indruk zijn welluidende, klankwisselende stem maakte. Hij zei, dat Charlotte Mulderman, bekend voor haar goed hart en haar menslievendheid, zich enkel schuldig had gemaakt aan lichtzinnigheid. Jong meisje, zonder vrouwenleiding opgebracht, vertroeteld kind van twee ooms, die haar te veel vrijheid lieten, was ze tijdelijk verdwaald geraakt. Zij verwachtte een kind, zij had het luiergoed gereed gemaakt - er was inderdaad iets van die aard in haar huis gevonden; maar dat de schrik voor de wereld, de vrees, schande over het hoofd van haar ooms te laden, op het laatste ogenblik, haar verstand verbijsterd hadden en zij niet wist wat ze deed; dat het kind overigens niet leefbaar was geboren en zij enkel schuldig was aan verheling voor de wet...

Hij vroeg haar vrijspraak.

Hij rekende op een gunstig vonnis, zei hij later, over het geval sprekend. De jury was bewogen. Een meedogende stemming heerste blijkbaar in de geest van 't Hof en zweefde over de propvolle zaal.

De president vroeg aan de betichte of ze nog iets tot haar verdediging bij te voegen had en, tot de ontzetting van haar verdediger, verliet ze de haar aanbevolen houding, diepgebogen te zitten, luid te snikken, indien ze kon, hetgeen ze tot dusverre uitstekend had gedaan.

'Ja', zei ze opstaande, een lelijk, tranenloos aangezicht tonend, en zij verbruidde 't al onhandig emfatisch zijn woorden herhalend, tenminste, wat ze ervan onthouden had. En zij voegde erbij, dat onze Lieve-Heer zijn getal hebben moest; ze had gedacht: 'Er zal een engelke te meer in de hemel zijn en gezeid: In den naam des Vaders, des Zoons en des Heiligen Geestes.'

De uitslag liet niet op zich wachten:

Charlotte Mulderman, beschuldigd van kindermoord met voorbedachten rade, doch in verzachtende omstandigheden, werd verwezen tot tien jaren gevangenis.

De tijd rolde heen.

De vergetelheid daalde over het meisje. Of zij haar jaren van opsluiting ten volle uitdeed, of genade kreeg, kan ik niet zeggen; maar herinner mij, dat wij eens - mijn zuster en ik - op een grauwe winternamiddag met een boodschap bij onze dagloonster binnengingen.

Zij woonde heel te velde en hield een kleine herberg, laag van plafond en somber die dag.

Een buurvrouw stond aan de schenktoog met haar te praten en, ons ziende, wilde ze weg.

'Maar wacht toch nog wat, wacht nog een "leitje" (lutteltje) ze zullen daar 
gaan zijn, ze komen hier pleisteren, ${ }^{15}$ ge zult het kind zien. Ze zijn ermee naar de doop.'

En de vrouw ging zitten.

Wat zo bijzonders zou ze zien?

Wij kregen het ook te weten: een kind van Plaatje Mulderman.

Plaatje Mulderman?

Och ja, wij herinnerden ons die naam: 'Is ze weer vrij, getrouwd?'

'Vrij, ja sedert, laat zien, sedert te Pasen een jaar geweest. Getrouwd, neen.'

En de buurvrouw deelde nu ook mee:

'Dat was een vreugd op 't hof bij haar onkels, ik was er, toen ze binnenkwam, 't was al ten beste en ze hadden ze zo verwenst indertijd! 't Was per$\operatorname{cies}^{16}$ de Verloren Zoon, waar de oude deken ne keer van preekte. 'k Heb het altijd onthouden.'

Op dit ogenblik kwamen een drietal mensen binnen: een jong boerenmeisje, een oude boer, zeker een der Muldermans en de baker, die het kind droeg.

Allen zaten neer en Mulderman bestelde drank. Dra had de herbergierster het kind op de schoot, weerde de dekentjes af en toonde een rond rood gezichtje, met de oogjes zo dichtgesloten, dat ze enkel twee rechte groeflijntjes vormden onder het voorhoofdje.

Maar het begon te schreien.

'Wacht,' zei de waardin en zij gaf het weer over aan de baker en liep weg.

En roekeloos, een wonde openrukkend, vroeg de buurvrouw aan de oude man:

'Lotje heeft zeker geen goest ${ }^{17}$ gehad om te herbeginnen en het dood te doen?'

't Is zot van zijn kind,' antwoordde de baker voor hem, die zweeg.

De herbergierster bracht een sauspan; in deze staken gestoofde, fijnvermorzelde aardappelen. $\mathrm{Zij}$ had het kind weer bemachtigd en met haar duim duwde ze brokjes in het schreiend mondje, dat die kost niet begeerde en hem bestendig uitbroddelde.

'Ik weet, wat dat klein goedje nodig heeft,' pochte zij, 'ik heb tien kinders gehad.'

'En hoeveel in 't leven?' vroeg de jonge meter, blozend als een rijpe paradijsappel.

'Nog twee,' zei ze.

Dat getal was welsprekend genoeg voor haar opvoedingsmethode.

'Hewel, Mulderman,' sprak de buurvrouw, heel luid als tot een dove, 'het spreekt te uwer ere, dat ge dat verdwaald schaap niet verstoten hebt; maar ge krijgt toch maar een slecht loon voor uw barmhartigheid, nietwaar?' het kind met de vinger aanduidend.

En hij, heel onderworpen, de schouders ophalend: 'Een mens heeft zijn geluk niet in zijn hand, en wat kunt ge aan zulke dingen doen, allo, wat kunt ge daar aan doen?' hoorden wij hem nog eens zeggen, terwijl wij het huisje verlieten. 


\section{Noten}

\section{Noten Meester Huyghe}

1. Sint-Gregorius: 12 maart, scholierendag op de feestdag van Gregorius de Grote $(+604)$, paus en kerkleraar.

2. In België erkende de grondwet (1831) het beginsel van de onderwijsvrijheid. De wet voorzag echter ook dat het officieel (niet-katholiek) onderwijs op 's lands kosten werd gegeven. Hierdoor ontstond een machtsstrijd tussen het officieel en het 'vrij' (= katholiek) onderwijs. De schoolstrijd zou in alle hevigheid losbarsten tijdens de liberale, antiklerikale regering Frère-Orban, die met de twee organieke wetten op het lager onderwijs (1879) het officiële (niet-katholieke) onderwijs prioriteit gaf en hiertoe overal gemeentescholen oprichtte. Over deze fase van de schoolstrijd zou Virginie Loveling later de roman Sophie schrijven (Gent 1885, 3 delen).

3. Kasken: kastje.

4. Veldslagen Napoleon: Meester Huyghe behoorde tot de zogenaamde Napoleonisten, soldaten die vochten in het leger van Napoleon Bonaparte (1769-1821), keizer van de Fransen van 1804 tot 1814-1815. Napoleon streefde naar de onderwerping van Europa aan het Franse oppergezag. Zijn belangrijkste tegenstanders daarbij waren Engeland en Rusland. Hier wordt verwezen naar een veldtocht in Polen. Meester Huyghe verbleef in de provinciestad Breslau (vanaf 1945 Wroclaw geheten). Wellicht vocht hij dus voor Napoleon in de Frans-Pruisische oorlog (1813).

5. Frak: jas.

6. Plankier: voetpad.

7. In 't lot gevallen: in de Franse republiek was de inschrijving (conscriptie) van alle jonge mannen voor de legerdienst verplicht. Het benodigde contingent, of: het aantal jaarlijks onder de wapens te roepen dienstplichtigen, werd vastgesteld door loting. De conscriptie werd na de Franse annexatie ook in België ingevoerd (1798), wat tot grote opstandigheid leidde (o.m. de Boerenkrijg, 1798). Zie ook hieronder, 'Het meesterschap', noot 1 (rijke jongelui konden zich 'vrij kopen').

8. Daarbij: Daardoor.

9. Bedorven: verwend.

10. Won: verdiende.

11. Schouwbord: schoorsteenboord.

12. 'Een kruisken geven': zegenen door een kruisteken op het voorhoofd te maken.

13. Maluwe: malve, kaasjeskruid.

14. Overbracht: doorbracht.

15. Kerkbaljuw: knecht in livrei met helleboord of staf, die de orde bewaart in de kerk.

\section{Noten Po en Paoletto}

1. Aanzicht: aangezicht.

2. Kas: kist.

3. Kapel (hier): tegen een muur aangebracht kastje, kleine nis voor beeld of relikwie.

4. Ammelaken: tafelkleed.

5. Kloosters afgeschaft: bij de Franse Revolutie (1789) werd door de regerende 'Constituante' (1789-1791) onder meer een aantal bestuurlijke maatregelen getroffen: afschaffing der gilden, onteigening van alle kerkelijke goederen en het ontwerpen van een grondwet die voorzag in de scheiding der machten. In september 1796 werden de meeste reguliere orden en kloosters in België afgeschaft, waarbij hun goederen in beslag werden genomen en openbaar verkocht. 
6. Boordels: boorden, rekken.

7. Kaskens en bakskens: kastjes en bakjes.

8. Teljoren: borden.

9. Saaiette: soort saai (sajet), lichte, gekeperde wollen stof, voeringstof.

10. Sarges: dekens.

11. Scheerling (dolle kervel) en goudwortel (stinkende gouwe): planten die gedijen op mesthopen en in het wild.

12. Puid: kikker.

13. Ribbe: weegbree.

14. Om het zeerst: om ter snelst.

15. Schavelingen: houtzaagsel.

16. Lekkerkoek: peperkoek.

17. Bolders: spelers van het bolspel (oud volksvermaak met houten bol die naar een staak wordt gegooid).

18. Schoon geverniste klederkas: mooi geverniste klerenkast.

19. Ezel (hier): ijzeren vouwbed.

20. Glashuizen: serres.

21. Met de schrik ontstaan: er met de schrik vanaf gekomen.

22. Met de duister: met het invallen van de duisternis.

23. Transparant (hier): lichtbak met opschrift.

24. Schone: mooie.

25. Stekje: lucifertje.

26. Alem: alaam, werktuigen.

\section{Noten Iets over het onderwijs der vrouw}

1. Athénées: athenea, meervoud van atheneum, (in België) middelbare school in het gemeenschapsonderwijs (gymnasium).

2. Beuzelingen: triviale zaken.

\section{Noten Het meesterschap}

1. In 't lot gevallen: zie hierboven, 'Meester Huyghe', noot 7. De zonen van rijke lui konden zich 'vrij kopen' door iemand in hun plaats te laten gaan die daarvoor betaald werd.

2. Jok: juk.

3. Rosalie Loveling brengt de Camera Obscura van Hildebrand ter sprake om te bewijzen dat vrouwen thuis de baas zijn. Mr. Hendrik Johannes Bruis treedt op in het verhaal 'Een oude kennis', dat voorkomt vanaf de eerste druk (1839). Het verhaal illustreert volgens Loveling de stelling dat geen enkele vriend van de heer des huizes een uitnodiging om te blijven souperen zal aanvaarden indien die niet door diens echtgenote 'bekrachtigd' wordt. Zie Hildebrand, Camera Obscura, ed. Willem van den Berg e.a. (Amsterdam 1998) deel 1, 134:

'Kom, kom,' zei de dokter, 'ik kom u hier afhalen, en gij soupeert met ons in de stad?' 'Ik weet niet,' antwoordde Bruis, die gaarne gezien had dat mevrouw bij deze uitnodiging tegenwoordig geweest ware.

4. Binst: tijdens.

5. Zie Polen: aan het eind van de achttiende eeuw ging de Poolse staat door verschillende opdelingen ten onder. Onder Napoleon herleefde de staat als het groothertogdom Warschau (1807-1814), maar het congres van Wenen bracht Polen opnieuw onder Pruisische, Oostenrijkse en Russische heerschappij. In het door Rusland bezette gedeelte van Polen braken in 1830 en 1863 opstanden uit. Maar ook in het Pruisische gedeelte bleef het volk opstandig of dan toch weinig meegaand met de bezetter. 


\section{Noten De kwellende gedachte}

1. Overgebracht: doorgebracht.

2. Onderhoord: vernomen.

3. Poseren: positioneren.

4. Hoe is het haar aangekomen: (ongebruikelijke uitdrukking, letterlijk vertaald uit het Frans: 'Comment ça lui est arrivé') hoe is het gebeurd? Hoe is het haar overkomen?

5. Opdeden: voordeden.

6. Kerfdieren: insecten.

7. Wrangkruid of wrangwortel: soort nieskruid.

8. Had er geen trouw in: vertrouwde het niet.

9. Hottonia: plantengeslacht van de familie Primulaceae; een van de twee bekende soorten is de waterviolier. De stengel rijst op uit een rozet en draagt een krans van witte of lichtlila bloemen met geel hart.

\section{Noten Meesterschap}

1. Kornis: kroonlijst.

2. Abeel: populier.

3. Kladdergoudsnippers: snippers van klatergoud (vals bladgoud).

4. Armmeester: armenvoogd, lid van het burgerlijk armbestuur.

5. Huuraar: huurder.

6. Keppe, knuist: synoniemen voor lieveling, troetelkind.

7. Zocht zij haars gelijke: had zij haar gelijke niet.

8. Vespers: (in de rooms-katholieke eredienst): (hier) avonddienst in de kerk op zon- en feestdagen.

9. Geven: eten geven (aan de beesten).

10. Smousjas: kaartspel waarbij de jas of boer de hoogste troef is.

11. Malkander: elkaar.

12. Het grote gilde: de gehuwden; in 't groot gilde gaan: huwen.

13. Gepijpt: geplooid.

14. Mankeren (uit het Frans: manquer): ontbreken.

15. Kroos: rente.

16. Achterblijven: wegblijven.

17. Den troep: het leger.

18. Starrenheer: een leger (heer) van sterren.

19. Ronkend (van een kat): spinnend.

20. Schotelhuis: bijkeuken waar de vaat wordt gedaan.

21. Trekt... toe: tast... toe.

22. Duivepier: duivenhok.

23. Draafje: drafje.

24. Aan de boet zijn: een boete oplopen.

25. Gesteend: gekreund, gehuild.

26. Verdrommen: verdrummen, wegdrummen.

27. Sarge: deken.

28. Subiete: plotselinge, onmiddellijke.

29. Steende: kreunde.

30. Schotelwater: vaatwaswater.

31. Onderstaan: zich verstouten, wagen.

32. Schorre: plat stuk zandsteen.

33. Schrappend: schrapend.

34. Tissend: tergend, plagend. 


\section{Noten Vrijheid - Blijheid}

1. Slekkevet: slakkenvet, erg vet.

2. Trekker: handvat of ring aan deur of lade.

3. Achtuurbloem: roodgele daglelie.

4. Debiet: opbrengst, productie.

5. Wies: o.v.t. van wassen, groeien.

6. Trekken: tochten.

7. Schrijling: schrijlings.

8. Borstels: dikke, stijve, uitstaande haren op het lichaam van varkens of wilde zwijnen.

9. Vaardig: klaar, gereed, bereid.

10. Hondsdulle (of: hondsdille) en henneslei: onkruidsoorten.

11. Deken: (rooms-katholiek) bestuurder van een district of decanaat waarin een bisdom is verdeeld; het decanaat omvat meerdere parochies die door pastoors geleid worden.

12. Pluimsteen: puimsteen, sponssteen gebruikt om te schuren en polijsten van houtwerk (en vereelte huid).

13. Principaal: directeur van een rooms-katholieke school.

14. St.-Pieterspenning: (r.-k.) vrijwillige gift van de gelovigen voor de H. Stoel.

15. Aftrekker: flessenopener, kurkentrekker.

16. Drinkgeld: zakgeld.

17. Uitgaan: een spelronde beginnen.

18. Schoolstrijd: zie hierboven, noot 2 bij 'Meester Huyghe'.

19. Mobilair: meubilair.

20. Gravurestrepen: inkervingen, groeven.

\section{Noten Plaatje Mulderman}

1. Moschen: Vlaams-dialectisch voor 'morsen'.

2. Oude jonkmans: ongetrouwde oude mannen.

3. Eigendom met uitpacht: eigendom waarvan een deel wordt verpacht (verhuurd).

4. Plag, plagge: afgestoken gras- of heidezode.

5. Klak: pet.

6. Barvoets: blootsvoets.

7. Zat: dronken.

8. Blare, blaar: lichtzinnige vrouw.

9. Tewege: onderweg.

10. Gendarmen: marechaussees.

11. Kolbak: berenmuts

12. Vaam, vadem: lengtemaat van zes voet.

13. Verworgd: gewurgd.

14. Assisenhof: (in het Franse en Belgische rechtssysteem) gerechtshof met (volks)jury, dat oordeelt over zware misdrijven.

15. Pleisteren: de reis onderbreken om te rusten en te eten.

16. Percies: (Vlaams-dialectisch voor) precies, net.

17. Goest: goesting, zin. 